\title{
A REAPROPRIAÇÃO DO ESPAÇO A PARTIR DA INTEGRAÇÃO AGRO-INDUSTRIAL
}

Tese de doutoramento, apresentada ao Departamento de Geografia da Faculdade de Filosofia, Letras e iências Humanas da Universidade de São Paulo.

Orientador:

Prof. Dr. PASQUALE PETRONE 


\section{$\underline{\underline{N}} \underline{\mathrm{D}} \underline{\mathrm{I}} \mathrm{C} \underline{\mathrm{E}}$}

1. INTRODUÇÃO; - "WU-KU" - As sèmentes essen-

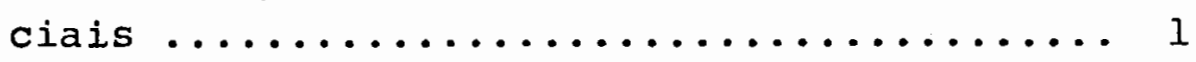

2. As bases da expansão da cultura da Soja nos Es-

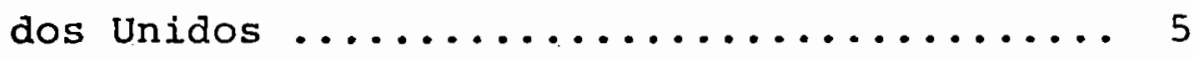

2.1 Caracteristicas principais da exploração a-' grícola Americana (até 1930) ........... 6

2.2 A Formação do "Complexo Soja" Americano .... 23 2.2 .1 Dominação do Mercado Interno ....... 24 2.2.2 Os Efeitos da Segunda Guerra Mundial. 30

2.2.3 o Comportamento do Mercado Interno '

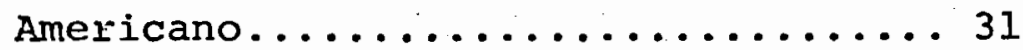


2.2.4 A Reestruturaido Mercado Mundial de Produtos Primários ("Commodities").. 37

2.2.5 Eventos Políticos nos Mercados de ' Pós-Guerra.................. 40

3. Transformações recentes nos Mercados Mundiais de Soja, de Oleos Alimentícios e Tortas Protēicas - A Consolidação econômica da Soja em termos Mundiais..47 3.1 Formação do Mercado para a Torta ........ 53

3.2 O Processamento Industrial ........... 55

3.3 O Modelo "Milho-Soja" ............... 59

3.4 Os Limites Técnicos de Substituição de Oleaginosas ........................60 60

4. Mecanismos de Preços de Mercado .............. 62

4.1 O Mercado Interno Americano ............6 62

4.2 Mercado Mundial ................... 65

4.3 Reflexos dos Preços da Soja no Comportamento de outros "Commodities" ...............66 66

5. Perspectivas de Mercado $\ldots \ldots \ldots \ldots \ldots \ldots \ldots \ldots .69$

Demanda Potencial ........................69 69

5.1 O Advento da Soja Brasileira no Mercado Mundial .......................... 75

5.2 Os Sistemas Alimentares na "Ordem do Dia" .. 76 
6. Transformacōes nos processos produtivos no Sul do Brasil e a penetração do "Complexo Soja" ....... 80

6.1 Efeitos da Politica de Substituição de Im portaçöes ...................... 83

6.2 o Advento do Binômio "Soja-Trigo" ....... 88

7. A Integração da Região de Assis. - São Paulo ..... 94

7.1 As bases naturais da organização da produ-"

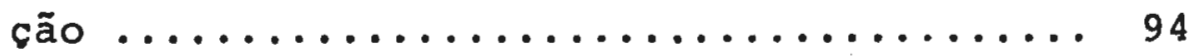

7.2 Condições históricas da organização da produção ......................... 99

8. . o Processo de Integração ................ 108

8.1 A Divisão do trabalho na produção pecuária regional ..........................113

8.2 A adoção do binómio "Soja-Trigo"-as prē-con

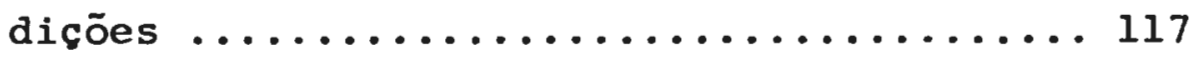

8.3 A ocupação territorial do binómio "Soja-Trí

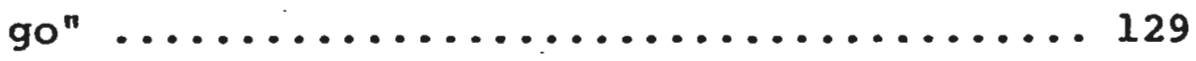

9. Divisão Técnica e Social do Trabalho .......... 141

9.1 o processo de Trabalho ................ 144

9.2 O Avanço na divisão Técnica do Trabalho ... 150

9.3 o Sistema de Máquinas ............... 159 
10. O papel do Estado e o Sistema Creditício ....... 168

10.1 As novas bases do Sistema Crediticio ..... 171

10.2 A política creditícia da década de 1970 e seus efeitos na Micro-Região Homogênea de Assis ......................... 174

10.3 o papel do sistema Creditício na reprodução do processo ..................... 183

11. As Transformações nos meios de Acesso à Terra ... 191

11.1 A Reconcentração Fundiāria ............ 191

11.2 As transformações na composição do pessoal ocupado .......................... 195

11.3 o Acesso à Terra ................. 207

12. A Urbanização dos Trabalhadores ............. 204

12.1 Um perfil do nūcleo da Tarumã ......... 207

12.2 Um perfil de população $\ldots \ldots \ldots \ldots \ldots \ldots \ldots 213$

Conclusões ............................. 223

Bibliografia ........................... 229

Apêndices 


\section{INTRODUÇ̃̃O}

Compreender as transformações ocorrentes na kicroRegião Homogênea de Assis, é, antes de mais nada compreender o universo em que essas transformações ocorrem, isto é, os seto res externos atuentes no desenvolvimento de novas formas de articulação, o grau e os limites em que o processo sobredetermina a artiçulação dos meios de produção em relação ao espaço e a sociedade。

Procura-se analisar a região dentro de um contexto histórico em que ela se integra a um complexo moropolístico fortemente verticalizado, com mais de cinquenta anos de tradi ção e pelo menos trinta anos de dominação do mercado mundial.

A cultura da soja não foi estranha ao sul do país, tendo sido introduzida no começo do século. As referências sobre suas "virtudes" por trabalhos de fomento a partir de 1950, a sua adoção como forrageira no sul e como fonte de óleo comestível, a existência de variedades adaptadas com boa produtivida de, são fatos demonstrativos da relativa familiaridade com a cultura.

Chega a chamar a atenção a convivência, no tempo, de processos produtivos em franca expansão, o que permite afirmar que não estarão no comportamento do mercado, em si, as possibilidades de transformação espacial e social.

Muito embora a expansão da soja se ja hoje mais ex- 
pressiva que a do trigo, a ruptura com os processos tradicionais de produção deu-se pela adoção do "binômio soja-trigo" no sul do país。

A soja vem compor o binômio mais como uma inovação técnica na melhoria dos processos produtivos do trigo do qual persegue-se politicamente a auto-suficiência.

A sua transformação em produto principal embora te nha ocorrido por uma situação conjuntural favorável de mercado, consolidou-se num rápido processo de expansão em áreas e inte gração vertical, facilitada pela "internalização" do "complexo-soja", o qual passa a comandar "de dentro" os padrões técnicos do processo produtivo.

o fato historicamente essencial nessa ruptura é a possibilidade (natural) da formação do "binômio soja-trigo", isto é, as condições naturais de clima, solo etc. que possibilitam u彑 ma rotatividade maior do capital fixo aplicado no processo produtivo.

A reapropriação do espaço e a definição de zonas produtoras integradas aos processos produtivos construidos e controlados por complexos monopolísticos organizados a escala mundial, corresponde, portanto, a uma intcrnacionalização do espaço que tende a responder segundo comandos e ritmos compostos a escala mundial.

Corresponde portanto a uma nova etapa da divisão internacional do trabalho onde a "territorialização" das ativi- 
dades agrárias tendem a ocorrer segundo a "racionalidade" que diz respeito às necessidades e padrões de acumulação ao nível da inaústria.

Isto não significa entretanto o mesmo padrão de acumulação em todos os segmentos do processo produtivo, mas ao contrário, à transferência para a indústria de sua capacidade de capitalizar, no mercado, as rendas geradas no processo produtivo imediato。

A "internalização" de bases técnicas mais avançadas de produção, tendo como pressuposto a produtividade do trabalho e a tendência à maior rotação do capital fixo, implica também na necessidade da rotação do próprio capital em suas formas sucessivas: capital dinheiro, capital-mercadoria e capital produtivo。

Isto implica na forte verticalização experimentada pelo processo produtivo tanto historicamente como em seu advento recente no Brasil, com a necessária articulação entro setores industrial, comercial e financeiro num contexto de internaciona lização dos processos.

Várias consequências podem ser retiradas disso no que diz respeito reapropriação do espaço. Tendo em vista o caráter internacional da produção pela tendência à equalização do processo produtivo traduzido numa homogenização dos meios de - produção a nível internacional, os territórios integrados são de ordem a possibilitar a obtenção de rendas diferenciais a escala mundial, o que implica numa incorporação desigual e descon 
tínua dos territórios, onde as "leis" de transformação são en contradas fora do território.

O recorte de uma porção do território para estudo é apenas uma estratégia, um ponto a partir de onde se procura ler os processos mais amplos que a atravessam. Feito o recorte, (a Micro-Região Homogênea de Assis), foi necessário logo sair dele para avançar a reflexão.

o recorte territorial, referido como região não ul trapassa o caráter de "noção" do vocábuloo o critério de defini ção do problema definiu-se pela evidência empírica. A escolha da Micro-Região Homogênea de Assis correspondeu a uma "racionalização nas bases técnicas de produção do conhecimento" se as sim se pode dizer.

As bases territoriais sobre as quais se assentam os indicadores dos processos em andarnento são bastonte móvej.s.A "contabilidade regional" feita de forma inadvertida pode levar a vários equívocos。

Para compreender a extensão e o caráter do processo em marcha e a condição relativa da região de Assis em face do processo esboçando-se como zona produtora de grãos (um segmento), foi necessário desvendar os aspectos essenciais do "com plexo-soja", suas origens, suas formas de atuação e suas bases econômicas e políticas.

Justifica-se assim uma incursão à história da produção industrial da soja e das estratégias de longa duração de construção do mercado mundial.

Fica assim mais ou menos claro que entre o céu e a terra há mais intenções do que se pode imaginar. 
"WU-KU - AS SEMENTE ESSENCTAIS

O feijão soja, "o soja" ou "a soja" (Gly.cine max) é ưna planta originária do Sodoeste Asiático, possivelmente da Nandchúria, entre os paralelos $40^{\circ}$ e $50^{\circ}$ de latitude norte.

Embora seja corrente a afirmação de que é una das mais antigas plantas cultivadas do mundo (cerca de ....... 5000 anos), as primeiras referências escritas parecen datar de 2838 a.C., sendo mencioneda nos mais antigos escritos chineses que descreveram as plantas.

Relatos de 2207 a.C. já fazem referência a solos apropriados, tempo de plantação, variedades para diferentes finalidades, etc.. Na China, a soja era considerada uma das cinco sementes "Wu-Kul, junto com o painço, a cevada, o trigo e o arroz, isto é, uma das cinco sementes essenciais à existência da civilização chinesa.

Apesar dessa tradição milenar no consumo e expe riência no manejo, verificada a partir da China, a soja so

(1) c.f. Rohde, G.M - "A História da Soja" in lo Simposio Nacional da Soja, Porto Alegre, 1975; ver também "a soja no Brasil Central" - Fundação Cargill, 1977; Morse, W. "History of soybeans production"- Interscience V.I. I950; Nagata, T. "Agro-genecological aproaches in the variety differentiation in Soybeans, Glycine max (I.) Merrill. " in" Proceedings of a Symposium on Tropical Agricultural Reseádches. Tokio, Tropical Agricultural Research Center,
p.137-168. 
passa a ter importância, no mundo ocidental no século $\$ X,-$ depois de um longo "processo de penetração no Ocidente onde passa de curiosidade botânica e objeto de estudo de natura lista, a um dos principais produtos do mercado mundial de bens primários num mundo carente de proteínes.

As regiões de origem, onde as condições eco l6gj.cas naturalmente propícias permitiram uma expansão con tínua e.uma forte participação na produção mundjal, não são contudo as grandes regiões exportadoras nem mesmo ti ve ram maior papel na construção do mercado mundial da forma como ele se apresenta. Serão condições sociais e economi cas muito específicas, as que irão contribuir para a trang formação de um produto regional asiático de consumo dire to numa das principais matérias primas da indústria alimen tar humana e animal.

Várias referências permitem localizar o iní cio desse processo no sécurö XVII, quando a soja passa a ser descrita e cultivada experimentalmente em jarảins botâ nicos franceses ingleses. As primeiras referências à soja nas Américas datam do início do século XIX, mas só no últi mo quartel desse século passa a ser cultivada tanto nos ES tados Unidos como na Europa.

Em 1880 teve início a aplicação da soja como forragem para suínos e bovinos nos Estados Unidos. A grande campanha de fomento teve início em 1898 através do Departamento de Agricultura de Washington. Consta que te- 
riam sido introduzidas cerca de duas mil variedades asiáticas para as quais a aceitação foi surpreendentemente rápida, favo recendo sua transformação numa das maiores culturas da lavoura norte - americana.

Entretanto sua expansão como produto comercial e matéria prima industrial só encontra expressão depois de 1930 áentro de um contexto social e político definicio pela grande depressão econômica por que passaram os Istados Unidos, como se verá.

Bm outros países de latitudes médias, principal mente no sul da Europa foi também passível o sucesso da produ cão. Foi o que aconteceu na Itália (Iiguria, Fnilia, Marcas), no sul da França, na Bulgária, na Hungria e nas regiões mais quentes da União Soviética a par de tentativas européias em colôniasafricanas. Foi o caso dos franceses em Nadagascar e dos belgas no Congo; onde entretanto a cultura não. pròs perou. (2)

A adaptação de variedades para uma produção econômica não se coloca também como um pressuposto de sua adoção pela agricultura dos diversos países. Mesmo no Brasil

(2) c.f. Pimentel Gomes, "A Soja", Nobel S.A. 49 Edição, São Paulo, p. 9-12. 
há que se considerar pelo menos duas etapas no processo de adoção da soja, ou seja (a) a sua adoção biológica, desartị culada em todo o sul do Brasil. Mesmo tendo ganho expressão regional, como foi o caso da região de Santa Rosa no Rio Gande do sul, a partir de 1928, inclusive com extração do óleo comestível, não teve o significado nem a expressão de (b) sua integração nos processos produtivos do que se denominou o "complexo-soja" americano. O significado social e as implicações econômicas dessa integração, exigem, para a sua compreensão, un exame minucioso do progresso de construção do processo de produção, o qual escapa do âmbito do estabelecimento agrícola e vai senco jominado progressivamente pela indústria com todos os ingredientes da fase monopolística da acumulação do capital, somo se verá.

Corresponde igualmente a un processo de substituição de produtos "naturais" de países tropicais pobres no mercado mundial de óleos e gorduras com uma progressiva deterioração de suas condições de troca, bem como a quase total desarticulação de suas bases produtivas internas.

As condições agudas de endividamento apontam na direção de uma reconversão econônica em escala mundial ocorrendo uma ruptura com os padrões de produção e acumula ção atuais pelo "imenso progresso na souialização da produção, particularmente no dominio dos aperfeiçoamentos . e inovações técnicas, ${ }^{(3)}$ indicando a consolidação de uma nove ordem social.

(3).f.H1lferding; "O Capital Inanceiro". onde esclarece... " O Capitalismo, chegado a sua fase imperialista, conduz à beira da socializaçao integral da produção; ele arrasta os capitalistas, seja como for, indevendentemente de sua rontade e sem que eles tenham consciência disso, para uma nova ordem social, inter media entre a livre concorrência e a socialização iñ tegral. A produção torna-se social mas a apropriaçaó 
2. AS BASES DA EXPANSTO DA CULTURA DA SOJA NOS ESTADOS UNIDOS

\section{Introdução:}

Dentre os diversos fatores que contribuiram para o desenvolvimento da cultura da soja nos Estados Unidos po dem ser arrolados como mais importantes:

- a mecanização a diesel, que liberou importan tes parcelas de área cultivada reservadas à alimentação de animais de tração;

- a difusão de milho híbrido, que permitiu um crescimento da produção pelo aumento da produ tividade, tendo possibilitado a redução de $\underline{a}$ rea plantada;

- a política de restrição das superfícies culti vadas (algodão, cerais, principalmente milho e trigo) e que não atingiu a soja;

- a polftica governamental de subsídio à recupe ração dos solos depauperados por um manejo ex tengivo e predatório;

- a perfelta adaptação dos processos de produ ção da soja aos processos aplicados ao milho e ao trigo, inclusire equipamentos, o que per mitiu a produção da soja sem investimentos a- 
dicionais, pela utilização das colheitadeiras mecânicas desde os anos 30.

ls baixos preços da depressão permitiram a ex pansão da cultura da soja que se desenvolveu a partir da re gião do Decatur no Meio-Oeste americano.

Uma das primeiras atividades da A.S.A. (AmerI can Soybean Association) fundada em 1918 foi o trabalho de fomento. Levou a efeito campanhas de promoção da cultura, ain da desconhecista no Meio-Oeste, organizando trens-exposicão junto à estradas de farro, os quais circulavam com o objetivo de familiarizar os agricultores com a cultura.

A partir de 1936 o apoio do governo americano se fez refletir no apoio às pesquisas em Universidades e Centros de Pesquisas e especialmente na criação e manutenção do Laboratório Americano de Pesquisas de Urbana, especializado no desenvolvimento de produtos industriais da soja, do óleo e da torta.

\subsection{Características principais da exploração agrícola ame - ricana (até 1930)}

A economia anericana organtzou-se e desenvolveu -se em um meio protegido por tarifas e barreiras (tarifa protecionista de Mackinley em 1890), até 1914 sob governo repu blicano.

A indústria americana teve assim todo um conti- 
nente a equipar, recursos enormes em matéria prima para trang formar, recursos energéticos substitutivos da força humana (carvão, petróleo, energia hidráulica) para explorar.

Sendo um tmenso país, fracamente povoado (deven do grande parte de seu crescimento à imigração da força de trabalho), houve desde cedo uma tendência a boa remuneração do trabalho escasso, sendo portanto o custo da mão-de-obra na produção bastante elevado, ao passo que a energia não humana pôde ser fornecida desde cedo a preços que compensavam a subs tituição.

Como consequência, a organização econômica nas diversas esferas produtivas assentou-se em um processo contínuo de substituição da energia humana, dispendiosa,pela ener gia "natural" e mecânica, sendo pois um de seus aspectos marcantes a mecanização precoce se comparada a outros países de igual nível de desenvolvimento.

O conceito básico de agricultura mecanizada popularizou-se na Inglaterra a partir do século XVIII e embora conhecida nos Estados Unidos tardou a se expandir. Em 1851 fo ram fabricados cerca de mil unidades do ceifador de Cyrus McCormick substituindo milhares de agricultores. Foi, entre tanto, a guerra da Secessão que tornou a intensificação da energia mecânica um processo generalizado.

A mobilização nortista de mais de um milhão de agricultores fez diminuir a oferta de braços nas fazendas obrigando os agricultores a adotarem dispositivos poupadores 
de trabalho humano.

Máquinas de ceifar e enfeixar (patentes de 1870) foram empregedas na produção e colheita do trigo e: em 1880, $80 \%$ de todo o trigo já eira trabalhado por máquinas.

Nessa época quase todo o equipamento agrícola era de tração animal. Com o advento do trator, em 1910, ocorreu uma verdedeira revolução agrícola, declinando o número de mulas e cavalos e diminuindo a área reservada à manutenção dos animais de trabalho, como mostra a tabela abaixo:

TABELA 1.1

NỨRERO DE TRATORES E ANIMAIS EM FERIODOS SELECIONADOS ANO TRATORES $\begin{array}{ll}\text { POTÊNCIA } & \text { CAVALOS } \\ \text { NÉDIA. } & \text { E.V.) }\end{array}$

$\begin{array}{crrr}1910-1911 & 1.000 & - & 27.000 .000 \\ 1940-1945 & 3.500 .000 & 30 & 11.630 .000 \\ 1960 & 5.000 .000 & 68 & 3.000 .000\end{array}$

Fonte: Clough e Marburg - The Economic Basis of American Civilization - ToJ. Crowell Co. New York, 1968.

O trator e a maquinaria serviram para consoli dar as grandes propriedades fazendo crescer em $1.50 \%$ a unidade de área por trabalhador agrícola em termos médios, duplicando a produtividade média, quadruplicando a produção entre 1870 e 1945, quase triplicando a área cultivada no mesmo período.

A aplicação da mecanização em larga escala ace- 
lerou a dispensa de meeiros - principalmente no sul - recon centrou a propriedade pela introdução de operações de grande escala viabilizada pelos arrendamentos anuais de terras, aprofundou a sazonalidade da aplicação do trabalho vivo na agri cultura criando um exército de temporírios.

Uma melhor compreensão dessas mudanças pode ser obtida pelo testemunho de Baulig, em 1930. "Nas partes mais secas (do Kansas), a cultura revestiu, de repente, um caxáter francamente industrial. Todo o trabalko se faz mecanicamente: - trator, rebocando charruas múltiplas, cultivadores a disco, semeadoras, combinadas, permitem a dois homens cultivar um es tabelecimento de 400 a 800 ha. Mesmo essas dimensões parecem insuficientes: segundo os peritos, o rendimento méximo corres ponderia a uma exploração de 2.000 ha, dos quais 500 a 600 ha em trigo, outro tanto em pousio e. o resto em pastos e bal dios (1).

... "os cinquenta a sessenta mil trabalhadores urbanos que até recentemente ainda vinham alugar os seus braços para a colheita desapareceram. O pequeno explorador, esma gado por uma concorrência desigual é ataído para a policultu ra; mais frequentemente renuncia e parte para a cidade"

As consequências desse processo são: urbaniza = cão crescente da população restando à agricultura baixas ta xas de população empregada, salvo no sul e no leste. "Por vol

(1) Baulig, H. "Amérique Séptentrionelle - A.Colin. Paris

(2) Baulig, H., op. cit. 
ta de 1970 a agricultura mobilizava apenas $12 \%$ da população a tiva do país."(3) Firma-se a exploração extensiva (com exce ção do sul), sendo relativamente baixo o valor da terra, salvo em áreas de culturas especializadas, "tornou-se mais vanta joso cultivar brutalmente algumas centenas de hectares cor dois ou três homens e máquinas, deixanao cerca de metade da terra em pousio em cada ano, não estrumanỏo, não empregando o adubo, correndo o risco de ter de se contentar com rendimen tos baixos do que fazer apelo a uma mão-de-obra oito a dez vẹ zea mais numerosa, trabalhardo toda a terra en cada ano, praticando um sistema de afolhamentos, alimentarido-a com adubo, permitindo que cresçam em muito maiores proporções os rendi mentos".(4)

Uma outra consequência desse padrão de organizą ção da agricultura, isto é, a exploração extensiva e mecanizge da numa economia concorrencial até os anos 1929-30 foi a ex pansão da área cultivada com um enorme desperdício de rique zas naturais。

O esbanjamento marcou todos os setores econômicos constatando-se uma aceleração significativa nos períodos relativos ìs Grandes Guerras; no setor agrícola a depredação de milhões de hectaresm Ioram convertidos em "dust bowls". (5) No sul e oeste uma agricultura predatória contribuiu para o

(3) Cf. George, Pierre - A Economia nos E.U.A. - Publicações D. Quixote, Lisboa, 1970,

(4) George, P. - op. cit; o autor está analizando os proces sos produtivos dos Estados Unidos tendo como modelo os processos intensivos da Europa.

(5) bacias de poeira. 
desnudamento de vastos espaços abandonados à erosão (ravina mento e deflaçäo pelo vento) nos intervalos dos períodos de cultura; ocasionou uma perda importante de terra arável, um emprobecimento do patrimônio agrícola nacional.

Por volta de 1914 pôde-se observar a tendência à especialização agrícola por zonas. Os fatores que mais influíram na escolha do lugar foram: a natureza do solo e o clima. Mas como aconteceu com a indústria, a proximidade dos mercados, a facilidade da mão-de-obra e as possibilidades ade quadas de processamento do produto também tiveram influência. o cartograma abaixo demonstra a definição dessas zonas, oa "belt".

FIGURA 1.1 REGIOES AGR ICOIAS NOS ESTADOS UNIDOS

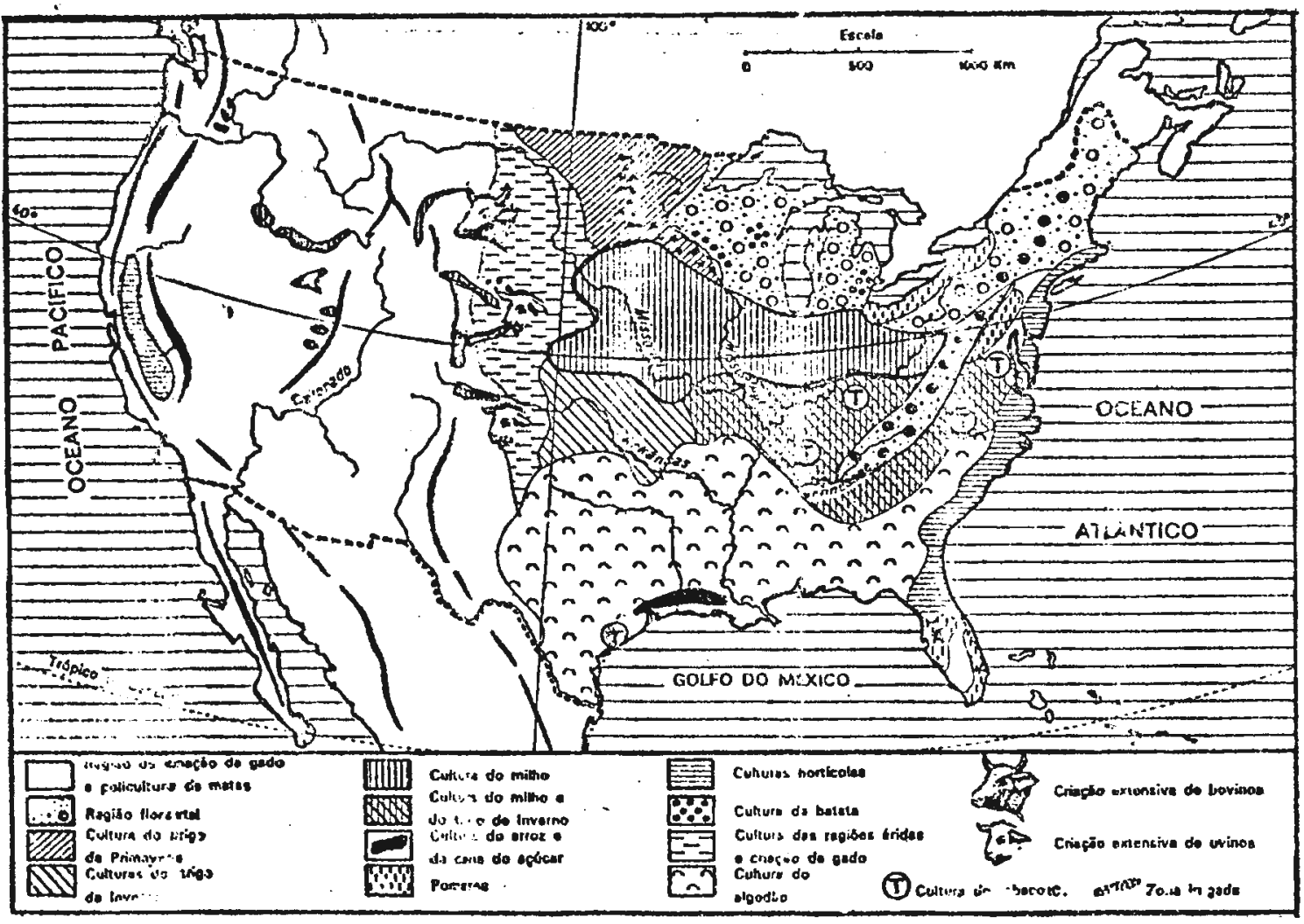

FONTE: c.f. GEORGE, op. cit, p. 74 . 
Quando irrompeu a Primeira Guerra a expansão da área plantada ocasionou a localização dos diversos tipos de a gricultura segundo padrões que se consolidaram até os dias de hoje.

"A norte e a leste de uma linha traçada de Norfolk na Virginia até o canto voroeste de Iowa encontra-se uma agricultura mista, destinada ao mercado doméstico e às gran des metrópoles, com maior especializaçäo em laticínios, horta liças e frutas frescas. No sul e a oeste dessa linha até o rio Ohio, incluindo Iowa e Missouri está localizada a Zona do milho ("Corm Belt") com criações de porcos e outros tipos de criação, a oeste dessa região até a fronteira ocidental do Kansas está localizada a zona do trigo ("Wheat Belt"); mais para oeste e sul, ranchos de gado bovino e caprino. 0 algodão que era cultivado no sul deslocou-se especialmente para o Texas." ( $5 a)$

Entretanto, nesse processo de egricultura extensiva e mecanizada, exigindo sempre maiores investimentos e re tornos monetários, a consolidação econômica só se deu pela exploração das melhores terras, pela renúncia às produções meno res. Disso resultou um imenso desperdício de riquezas naturais sob a forma de dilapidação de recursos minerais, e pela de predação de milhões de hectares abandonados a erosão.

O aumento do capital real na agricultura realizou-se durante a prosperidade erivada da Primeira Grande Guer ra; outra parte durante ou após a Segunda Grande Guerra. OB fazendeiros responderam $\dot{a}$ demanda de cereais e aos altos previlization.- T.J.Crowell Co. New York, 1968. 
ços internacionais por uma expansão da área plantada e um marejo menos cuidadoso do solo. O preço da terre foi elevado proporcionalmente ao preço do trigo - dificultando o acesso à mesma. Os investimentos privados realizados com a finalidade de produzir um aumento da oferta endividaram os agricultores com hipotecas que na grande parte dos casos não puderam ser saldadas; a expansẽo de oferta de trigo mais que proporcionanal à demanda provocou um rebaixamento nos preços intermacionais no pós-guerra; isto aconteceu com quase todos os bens pri mários, como pode ser verificado pela Tabela 1.2 abaixo:

- TABEIA 1.2. PORCENTAGEM DE PREÇOS PAGOS E RECEBIDOS PELOS AGRICULTORES EM PERÍODOS SELECIONADOS TENDO (1910-14) COMO BASE:

\begin{tabular}{ccc} 
PERfODOS & $\begin{array}{l}\text { PREÇOS } \\
\text { RECEBIDOS } \\
\%\end{array}$ & $\begin{array}{c}\text { PRECOS } \\
\text { PAGOS } \\
\%\end{array}$ \\
\hline $1910-1914$ & 100 & 100 \\
1919 & 215 & 198 \\
1925 & 156 & 165 \\
1932 & 68 & 124
\end{tabular}

FONTE: CLOUGH A MARBURG, op. cit.

Fm 1930, 38,5\% das fazendas estavam sob hipoteca e no sistema hipotecário adotado a renegociação das dívi das - a serem feitas todas ao mesmo tempo - ameaçava a liqui- 
dez dos Bancos que começeram então a retrair suas operações.

Negsa situação de desagtre econômico e financei ro, de pauperização extrema dos recursos naturais disponíveis os fazendeiros buscavam apolo governamental lançańdo mão de organizações corporativas já bem representadas no Congress $\delta^{\prime}$. Foram aprovadas leis de retardamento das hipotecas e fornecimento de fundos governamentais em bases bastante compensado ras.

Uma das primeiras medidas do "New Deal" foi a criação da A.A.A. (Agricujtural Adjustment Administration) a fim de providenciar as políticas adequadas de ajustamento da produção ao consumo, correção de disparidades entre preços de insumos e produtos e recuperação da "paridade" de preços a ní vel do agricultor.

Essa política foi implementada pela criação de um imposto sobre os fabricantes de produtos alimentícios (por exemplo 30 centavos de dolar por "bushel" (7) de trigo moido) a fim de obter fundos destinados a compensar os fazendeiros que reduzissem voluntariamente sua produção em termos de área plantada da maior parte dos cereais e oleaginosas. (8)

Tendo sido declarada inconstitucional pela Corte Suprema Americana em 1936, foi imediatamente substituida pela "Soil Conservation and Domestic Allotments Act" que paga va agricultores que deixassem de plantar o que havia em exces

(6) O "Bloco Agrícola" já estava instalado no Congresio.

(7) 1 bushel $=8$ galões ou 30,28 litros.

(8) não incluindo aí a soja. 
so, passando a plantar somente o que conservasse o solo e fazendo com que adotassem, obrigatoriamente, práticas conservacionistas como terraceamento, curvas em nível, etc..

Foi promulgado novamente o "Agricultural Adjust ment Act" (A.A.A.) que dava continuidade aos planos de conser vação, mas sobretudo tentavam controlar a área plantada a fim de manter os "preços de paridade" (9) a $90 \%$. A quantidade de terras plantalas com algodão, milho, trigo, tabaco e arroz eram então controladas mais para a manutenção dos preços do que para a promoção da conservação. Os plantadores só podiam obter o pagamento de auxílios à conservação do solo quando plantavam dentro das quotas previamente estipuladas por diver sos mecanismos (regionais e nacionais).

Nesise período acentuou-se o papel do governo fe deral na re-ordenação econômica do setor agrícola pela cria ção de vários orgãos que passaram a atuar - de forma articula da ou nạo - sobre os problemas de super-produção e preços ten dencialmente Iebaixados. A "Farm Credit Administration"(1933) reuniu agências de empréstimos agrícolas do governo para efetuar empréstimos subsidiados. A "Resettlement Administration." (1935) deslocou agricultores falidos para terras mais férteis.

(9) c.f, "Paridade é um desses estranhos conceitos surgidos na agricultura norte-americana. Assim, por exemplo, com esse vocábulo se indica o preço de um "bushel" de trigo ou mitho, que proporciona ao agricultor suficientes dólares ou centavos para adquirir em qualquer tempo, exatamente a mesma quantidade de produtos(roupas, sementes, - que for) que o agricultor podia adquirir no período de 1910-14 com o dinheiro que obtinha com a venda de um "bus hel" de trigo ou de milho. c.f. TEIXEIRA, E.F. - O TRIGO NO SUL DO BRASIL. Gráfica Ed. Iinotype, São Paulo, 1958, p. 9 . 
0 "Federal Energency Relief Administration" e a "Public Works Administration" trabalharam no sentido de melhorar a infra-eg trutra de escosmento das safras atuando sobre construção e me Ihoria da rede rodoviária.

De 1933 a 1936 foram feitos empréstimos no va lor de 3,7 bilhões de dólares e a ajuda de 1,2 bilhões de dólares. O governo federaI adquiriu terras dilapidadas dos agri cultores e organizou parques nacionais e reflorestamento. A política agrária posterior à Primeira Grande Guerra teve como resultado, por parte do Governo Federal, o dispêndio de " 6,6 bilhões de dólares, com os quais comprou 7 milhões de fardos de algodão, 254 milhões de hectolitros de milho, 670 wilhões de hectolitros de trigo além de outros produtos". (10)

Uma das características mais marcantes da estrú tura econômica dos países adiantados, no século XX foi o processo extremanente rápido de concentração da produção em um número cada vez menor de empresas a transformação dos bancos de simples intermediérios de pagamentos, (definidos por um grande número de casas independentes) em monopólios financeiros desprovidos da quase totalidade do capital-dinheiro do con junto da sociedade, de grande parte dos meios de produção e das fontes de matéria prima.

Este fenômeno ocorreu independentemente do pa pel do Estado, menos ou mais protecionista, em países como o Japão, a Alemanha, a França, a Inglaterra e os Estados Unidos. 
Já em 1909, nos Estados Unidos, cerca de $50 \%$ do valor da produção total era formada por $1 \%$ do total das empre sas empregando 30,5\% do total de empregedos. Em 1929 cerca de $70 \%$ do valor da produção total do país era formecida por 5,6\% das empresas, empregando $58 \%$ da população empregada, como demonstra a Tabela 1.3 a seguir.

Analisando a concentração a nível de médias e grandes empresas - valor de produção superior a 5 mil dólares - entre 1909 e 1933 pode-se notar dois momentos importantes : (a) o período anterior à crise de 1929 quando ocorre o cresci mento do número de empresas apesar da ccncentração e (b) ० pe ríodo posterior à crise de 1929 onde a concentração inclusí ve se reflete numa queda em valor absoluto do número de empre sas industriais. Entre 1929 e 1933 o número de indústrias de transformação com valor de produção de 5 mil dólares e mais de 210.959 estabelecimentos $\frac{\text { cilu }}{\text { para }} 141.769$ estabelecimentos em apenas quatro anos, o que representa o desaparecimento por fa lências e incorporações da ordem de 69.190 estabelecimentos, ou seja, uma queda de $33 \%$ no número de estabelecimentos e uma taxa de desemprego seguramente superior a $32 \%$ !

Em 1929, para as empresas com valor da produção superior a 5 mil dólares agrupadas pox número de empregados, nota-se que $48,9 \%$ das empresas (até 5 empregados) empregam $3,2 \%$ da mão-de-obra consumindo $3,9 \%$ da força motriz, enquanto $0,5 \%$ das empresas (com mais de 1.000 empregados) empregam $24,4 \%$ de mão-de-obra consumindo $27,0 \%$ da força motriz。

Se forem comparadas as empresas que ocupam até 


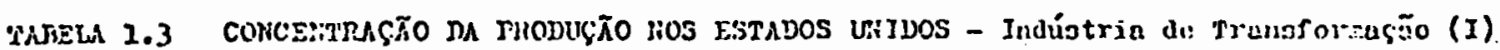

YALOR DA RTOUUSGO RUUAL

\begin{tabular}{|c|c|c|c|}
\hline \multicolumn{3}{|c|}{ WAIOR DE, 500 DOLARES } & 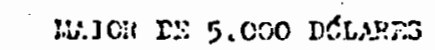 \\
\hline 1904 & 1909 & 1914 & 1914 \\
\hline
\end{tabular}

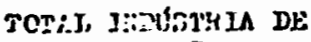

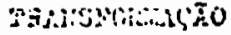

- Jir de cripresas

- Ur dir cuprugados

(en nistróes- $\$$ )

- Vuloz iotial da pro-

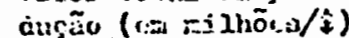

$\begin{array}{cccccc}216.180 & 268,491 & 272,518 & 177.110 & 190.303 & 210.979 \\ 5,5 & 6,6 & 7,0 & 6,9 & 8,6 & 0,8 \\ 14,8 & 20,7 & 24,2 & 24,0 & 60,0 & 70,4\end{array}$

Frepeshs cer valar DA

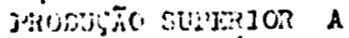

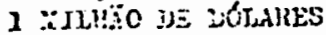

- :is de chyrecans

- iv? de ceprecradus (c.n injivines)

- Vezor total ó raroduçĩ̄o (cir bilnüues/

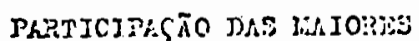

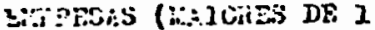

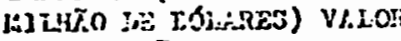
Da lliores: Dis lWDAS?!?IAS DE TRAHSFOIZUASTO

- Im cstabclecimentos

$\begin{array}{llllll}0,9 & 1,1 & 1,4 & 2,2 & 5,3 & 5,6 \\ 25,6 & 30,5 & 35,7 & 36,2 & 56,8 & 58,0 \\ 38,0 & 43,8 & 18,8 & 19,2 & 66,3 & 69,3 .\end{array}$

- Porcentengera da winode-oura ocunedu mas maiores

$\begin{array}{cccccc}1.900 & 3.060 & 3.819 & 3.319 & 10.327 & 1.753 \\ 1.4 & 2,0 & 2,5 & 2,5 & 5,0 & 5,2 \\ 5,6 & 9,0 & 11,6 & 11,6 & 40,2 & 48,5\end{array}$

- Porcentagen du valor total da produçäo ias majores sobrc o total

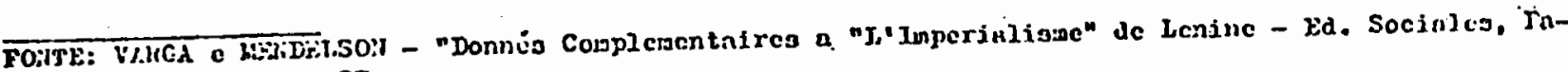
rits, 1950, p. 27. 
50 empregados com as empresas que ocupam mais de 50 emprega dos em 1929 observa-se que $86,1 \%$ das empresas empregavam $19,2 \%$ da mão-de-obra consumindo $17,7 \%$ de força motriz;onúmero de empresas de mais de 50 empregados correspondia a 13,9\% do total ocupando $80,8 \%$ da mão-de-obra, consumindo $82,3 \%$ da for ça motriz, como indica a Tabela 1.4 a seguir.

Quanto aos bancos, entre 1923 e 1934 o número de estabelecimentos com capital registrado de mais de 5 milhões cresceram quase 100\% enquanto os bancos com capital registrado inferior a 1 milhão de dólares sofreram uma queda para $34 \%$ do número total, no mesmo período.

A participação dos grandes bancos nacionais nos depósitos bancários, cresceu de $116 \%$ enquanto para os peque nos bancos a participação diminuiu $45 \%$ no mesmo período. In tre 1914 e 1936 o número total de casas bancárias nos Estados Unidos caiu de 26.274 para 15.752, isto é, diminuiram para $60 \%$ como demonstra a Tabela 1.5 a seguir.

Outro fato importante é a integração, isto é, a reunião em uma única empresa de diversos ramos da indústria que possam abranger sucessivas fases de tratamento da matéria prima ou desempenhar o papel de auxiliares, umas em relação às outras, incluindo aí a integração ao capital financeiro.

"A integração elimina as diferenças de conjuntü ra e assegura, também, ̀̀ empresa integrada uma taxa de lucro mais e tável. Em segundo lugar, a integração elimina o intermediário. Em terceiro lugar, possibilita aperfeiçoamentos téc nicos e por conseguinte, a obtenção de lucros suplementares 
TABEIA 1.5 CONCENTRAÇÃO DOS BANCOS NOS ESTADOS UNIDOS

a) Número de Bancos nacionais.

\begin{tabular}{|c|c|c|c|}
\hline ATTOS & $\begin{array}{l}\text { CAPITAL MAIOR } \\
\text { DE \$5 MILHOES }\end{array}$ & $\begin{array}{c}\text { CAPITAL ENTRE \$ I MILHÃO } \\
\text { E \$5 MILHÖES }\end{array}$ & $\begin{array}{l}\text { CAPITAI II } \\
\text { A } \$ \text { I MII }\end{array}$ \\
\hline 1923 & 21 & 100 & 8,063 \\
\hline 1930 & 39 & 177 & 6,822 \\
\hline 1934 & 40 & 182 & 5,245 \\
\hline
\end{tabular}

b) Porcentagem dos depósitos nos Bancos nacionais

1923

22,1

20,1

57,8

1930

43,3

17,1

39,6

1934

47,8

20,6

31,6

c) Nímero total de Bancos nos Estados Unidos

\begin{tabular}{ll}
1914 & 26.274 \\
1921 & 30.560 \\
1929 & 25.110 \\
1936 & 15.752 \\
\hline
\end{tabular}

FONTE: VARGA E IEENDELSON, op. cit. p. 95. 
por confronto com os da empresa "simples" (isto é, não inte grada). Tuarto lugar, na luta de concorrência que se desen cadeia no momento de uma forte depressão (diminuição dos negó cios, crise), quando a baixa dos preços das matérias- primas não acompanha a baixa dos produtos manufaturados, ela fortalece a posiçẽo da empresa integrada em confronto com a da empreas simples".

Os mecanismos de concentração financeira e inte gração industrial desenvolveram-se desigualmente segundo o gru po de indústrias como pode ser constatado na Tabela 1.6 abaixo: TABEL 1.6 PROPORCXX DAS ERPRESAS "GIGANTES" (BRPREGANDO MAIS DE 1.000 EMPREGADOS) NOS ESTADOS UNIDOS DM 1929 .

GRUPOS DE INUUSTRIAIS

- Material de transporte

- Borracha

- Siderurgia e sub-produtos

- Derivados do petróleo e carväo

- Outras máquitnas

- Oftcinas de reparo- ferrovias

- Metais näo-ferrogos e aub-pro dutos

- Produtos qufmicos a assemolhados

- Texteio

- Couros

- Produtor alimentarea a assemeIhados

- Pedra, argila e vidro

- Bencficlamento floreatal

- Papel asoemellados

- Impresgão

ancxos
He DE mMTESAS COM + DE 1000 EMIREGADOS

$\begin{array}{rr}131 & 66,0 \\ 33 & 65,0 \\ 160 & 41,7 \\ 26 & 37,3 \\ 144 & 34,8 \\ 63 & 28,5 \\ 40 & 23,0 \\ 31 & \\ 192 & 22,5 \\ 23 & 18,5 \\ 48 & 12,5 \\ 16 & 11,2 \\ 34 & 17,2 \\ 9 & 6,1 \\ 11 & 5,0 \\ & 5,8\end{array}$

66,0

65,0

4,7

7,3

4,8

8,5

2,5

8,5

2,5

7,2

6,1

5,0

FONTE! V.AHGA E MENDETSON, op. cAt., p. 45.

(1I) HILFERDING, R. O Capital Financeiro - citado por VARGA e MENDELSOH, op. cit., p. 46.

PROPORÇTO DE EMPREGADOS WM REIACCTO 10 Ne TOTAL DE TRABA LHUDORES NO GRUPO

(\%) 
As indústrias do grupo dos produtos alimentares e assemelhados játinham iniciado sua integração com a agricul tura, mas só a partir de 1929 a integração se acelera com a produção de alimentos compostos aproveitando os excedentes da agricultura e os preços baixos.

Nesse contexto de concentração industrial e financeira, de eliminação da livre concorrência e monopolização do capital e das matérias primas, emergiu o que alguns autores chamam o "complexo-soja" americaro.

\subsection{A Formação do "complexo-soja" americano}

Desde as camparhas de fomento de fins do século XIX - que serviram para introduzir e adaptar variedades a diferentes condiçōes clinúticas a a diversos usos, - até 1918, a soja permanece quase cono una planta desconhecida no interior dos Estados Unidos.

A partir de 1919, com a orgenização dos proảuto res da região de Decatur sob a A.S.A. (American Soybean Association) tem início um trabalho de divulgação a partir do Mejo -Oeste americano.

Um dos meios principais de divulgação utiliza dos naquela época consistiu na cooperação com as ferrovias pe ra a montagem e circulação de trens-exposição destinados a fa miliarizar os agricultores com o produto e com os processos 
de produção.

Com o advento do trator a diesel e sua rápida expansão na agricultura americana em torno dos anos 30 - até 1934 - expandiu-se rápidamente a área plantada, sobre as áreas antes reservadas à manutenção de animais de tração (cerca de $25 \%$ da área cultivada c.f. George $\left.P_{\bullet}\right)^{(12)}$. pande-se ainda sobre as áreas de restrição de plantio de ce reais, primeiro no "Coin Belt" depois sobre o "Wheat Belt",pe netrando no Meio-Oeste americano como planta forrageira e adu bo verde, pelo aproveitamento dos programas governamentais de financiamento e orientação técnica.

A pertir de 1928 são estabelecidos contratos de fornecimento com garantia de volume e preços entre a A.S.A. e indústrias esmagadoras. Com essa experiência tem início umä alianca duradoura entre produtores e indústria o que é o primeiro passo na organização da produção tendo por base a integração vertical e a montagem do que se tem chamado o "complexo soja", isto é, a produção, comercialização e atuação nos mercados de "commodities" sob o domínio do capital industrial.

2.2.1 Dominação do mercado intẹno

A soja vinha sendo aplicada largamente como adu bo verde na recuperação de solos dilapidados, como forrageira em rotação com gramíneas (principalmente milho, arroz) ou uti

(12)e.f.George, Pierre, op. cit, 
lizado diretamente na alimentação de suínos.

E dessa forma que apareca, pela primeira vez, nas estatísticas norte-americanas em 1924. Até 1925 as quanti dades esmagadas são mínimas e feitas ein caráter experimenta]. em pequenas usinas que tinham por função extrair outros tipos de óleos vegetais.

Somente a partir de 1934 a produção de grãos des tinados à trituração progride rapidamente. Antes de 1933 a su perfície colhida corresponde a menos de $25 \%$ da área plantada, enquanto em 1940 já se aproxima a $40 \%$ conforme démonstra a Ta bela 1.7 .

TABEIA 1.7 - SUPERF ICIES COM SOJA INOS ESTADOS UNIDOS EM PERÍODOS ESCOLHIDOS

AREAS ( em 1.000 he )

\begin{tabular}{|c|c|c|c|c|}
\hline PER IODOS & CULTIVADAS & $\begin{array}{c}\text { COLHIDAS } \\
\text { GRÃOS }\end{array}$ & $\begin{array}{l}\text { COLHIDAS EM } \\
\text { FORRAGEIRAS }\end{array}$ & $\begin{array}{l}\text { PASTAGENS } \\
\text { E ADUBBO } \\
\text { VERDE }\end{array}$ \\
\hline
\end{tabular}

\begin{tabular}{|c|c|c|c|c|}
\hline $1924-26$ & 768 & 179 & 506 & 82 \\
\hline $1931-33$ & 1.676 & 429 & 1.081 & 165 \\
\hline $1938-4.0$ & 4.220 & 1.640 & 1.771 & 809 \\
\hline
\end{tabular}

Durante a Primeira Grande Guerra os Estadoa Uni dos haviam importado grande quantidade de óleo de soja da Chi- 
na para suprir o mercado interno no setor alimentar.

A entrada abrupta para consumo forçado em situa ção de guerra, sem me.thores processos de refino e aromatiza cão causou um impacto negativo a nível de consumidor. Dessa forma, quando é re-iniciada a trituração da soje no final dos anos 30, 95\% do óleo obtido é destinado a aplicações indus triais (produção de tintas e vernizes).

Em 1930, apoiados na vaga de protecionismo de sencadeada pela crise de 1929, a A.S.A. e os industriais plei tearam junto io governo a criação de barrejres alfandegárias sobre óleos vigetaia, conseguindo a aprovação de leis proibj-tivas através de sobre-taxas martíidas até 1972.

O mercado interno ficou dessa forma livre para absorver a produção nacional em aplicações industriais. Ma aplicação em alimentação humana o óleo de soja sofria ainda a concorrência do óleo de copra, utilizado na produção de marga rinas e proveniente das Filipinas (15). Por outro lado, a crí se de superprodução agrícola orientou o óleo de soja para aplicações industriais.

(13) $152 \mathrm{mil}$ toneladas de óleo proveniente de trituração de cerca de un milhão de toneladas de grẽos.

(14) \$1,20 por alqueire (cerca de 13,8 litros) de grãos, isto é, o cobro do preço do mercado americano.

$\$ 0,35$ sobre o óleo comum mínimo de $45 \%$ ad valorem;

(15) os produtios provenientes das Filipinas não poderiam ser sobre-tarados pois esta era considerada território americano. 
A reativação da A.S.A. em 1928 e sua aliança com o capital industrial trouxe para o setor empresas já tradicionais na transformação de produtos agrícolas (milho, trigo, algodão, etc...) algumas das quais foram os exbriões de multinacionais atuando hoje no setor, construídas a partir de um grande número de fusões com pequenas empresas do ramolcomoé - caso de AE. Stanley e Central Soya atuando hoje, inclusive ro Brasil)。

- Muito embora o crescimento do mercado de óleo, - que corresponde de $15 \%$ a $20 \%$ do total do peso dos grãos a torta ( $80 \%$ a $85 \%$ do peso), não havia encontrado aplicação em meados dos anos 1930.

As indústrias envolvidas e o governo buscavam $\underline{\text { - }}$ vas aplicações inaustriais para os excedentes agrícolas. En quanto grande quantidade de trigo foi queimado en fornalhas de locomotivas, foram instalados laboratórios privados (como os Laboratórios de H. Ford em River Rouge), governamentais ou apoiados pelo governo, em vários centros de pesquisas e universidades, e especialmente, o Laboratório Americano de Pesquisas de Urbana (1936) que se especializou particularmente em sub -produtos industriais da saja: óleo e torta.

Os laboratórios de seleçã̃o puderam contar, para suas pesquisas, com milhares de variedades de soja recolhidas na China por técnicos americanos em missão de dois anos.

Houve também progressos na tecnologia da extração de óleos, muito embora os equipamentos "de ponta" capazes de extrair óleo por meio de solventes (gerajmente o hexano)se 
jam ainda importados da Alemanha)。

A nível da pesquisa bio-química foi conseguida a identificação dos ácidos aminados essenciais o que possibiIitou a criação de uma base científica às técnicas de preparo de rações balanceadas e a aplicação de tortas de soja na alimentação animal.

Tais rações passaram a apresentar excelente qua lidade e substituiram paulatinamente as farinhas de carne ou peixe e a torta de algodão.

Os fabricantes de matérias graxas hesitarare. em colocar no mercado o óleo de soja para alimentação hurana ten do em vista as experiências negativas ocorridas durante a Prí meira Guerra. Em 1934, porém, a A.S.A. usando de sua influência junto an governo conseguiu fazer incidir uma taxa de 3 cents por libia-peso na primeira transformação industrial do óleo de copra em território americano (16). Dessa forma abre-se o mercado de produtos alimentícios para o óleo de soja, com aplicação na produção de "margarinas".

Através desses expedientes a quantidade triturạ da passou de 9.000 ton. (em 1931-33) a 1,5 milhões de ton. (em 1938-40) conforme demonstra a Tabela 1.8 .

(16) o que representa cerca de 50\% do valor do óleo de soja. 
TABEIA 1.8 - UTILIZAÇT̃O DA PRODUÇÃO DE GRÃOS DE SOJA NOS ESTADOS UNIDOS POR PERIODOS ESCOLHIDOS (EM 1.000 TON)

\begin{tabular}{|c|c|c|c|c|c|}
\hline PERfODOS & $\begin{array}{l}\text { DISFONI } \\
\text { BISIDADDE }\end{array}$ & SEMENTES & $\begin{array}{l}\text { AI IMTNNAS ANO } \\
\text { AN IMAI }\end{array}$ & $\begin{array}{l}\text { TRITUU } \\
\text { RAÇ } \bar{O}\end{array}$ & $\begin{array}{c}\text { DIVERSOS } \\
(17)\end{array}$ \\
\hline $1924-26$ & 139 & 61 & 34 & 9 & 35 \\
\hline $193 I-33$ & 423 & 151 & 66 & 102 & 104 \\
\hline $1938-40$ & 2.103 & 415 & 135 & 1.500 & 53 \\
\hline
\end{tabular}

FONTE: BERLAN et allii - opo cit。

Nas vésperas da 29 Guerra Mundial os Estados Unidos já haviarn encontrado aplicação para o óleo e para a tor ta e os mercados internos estavam em franca expansão.

A integração abrangia os produtores, a inaús tria e o controle da comercialização desde que esses conglome rados passaram a controlar as exportações de o.leaginosas em geral e seus cerivados, entre países produtores e consumido res.

Nas vésperas da Segunda Guerra Mundial estavajá inteiramente nontado o que vários autores denominam "o complexo soja" omericano.

(17) por diversos compreende-se: exportações e grãos vendidos para alimentação animal sem processamento. 


\subsubsection{Os efeitos da Segunda Guerra Mundial}

O exame $0^{0}$ da Segunda Guerra na construção do "com plexo soja" americano exige uma série de enfoques que envol vem quatro aspectos em vários momentos.

- o setor de produção que inclui a produção do grão (agricultura) e seu processamentol indús tria);

- o comportamento do mercado interno americano como base para a expansão mundial;

- a desestruturação dos mercados internacionais durante a Guerra e sue re-estruturação no pós -guerra com mudanças fundamentais de posição entre produtores, exportadores e importadores por um lado e na composição dos diversos grupos de "commoditieg" entre os quais os grupos da soja, de outro lado;

- as bases políticas que condicionaram a eatruturaçẽo de uma ordem internacional no que diz respeito a expansão do "complexo soja".

Por outro lado, o exame dos dados de produção e fluxos comerciais permitem a distinção dos seguintes momentos fundamentais:

- período de Guerra, onde funcionaram mecanis mos especiais do troca; 
- o período logo após a guerra até 1952 a 55 , quando se definem novas tendências de consumo e inovações técnjicas começam a pesar na definição dessas tendências;

- as décadas de 50 e 60 quando ocorre a consolí dação econômica do complexo soja e se dá sua exaustão em termos anericanos, e dominação do mercado europeu;

- a décads de 70 que define novas tendèncias, tendo em vista o esgotamento da capaciasde de expansão americana, com a emergência do Bra sil como produtor importante.

\section{2 .30 comportarnento do mercado interno americano}

0 "New Deal" não teve o sucesso esperado. A eco nomia anericana embora terha crescido nẽo conseguiu fazer bai xar a taxa de desemprego além de 15\%. Dessa forma, o esforço de guerra representou uma retomada de crescimento, e a produção dobrou en quatro anos. A expansão industrial a demanda de bens de consurno e entre estes, os produtos de consumo alimentar também ocorreram.

Logo após o ataque japonès (1941) o governo tomou medidas de estínulo à produção de produtos graxos alimentícios tendo em viata os cortes de fornecimento da área asiá- 
tica (óleo de palma e copra). Por outro lado planificou a pro dução garantindo os preços dos grãos de soja ao nível do produtor, fixando tetos para óleo e torta, subvencionando os industriais para garantir margens de lucro nos volumes esmagados.

Meses depois do início da guerra os preços dả $\$$ ja já haviam aumentado en $50 \%$ e a área plantada expandido cer ca de $70 \%$. Os Erandes excedentes criados foram lançados no mer cado interno por meio de campanhas publicitárias através das quais a palavia de ordem era de consumir mais proteínas (tendo em vista a sustentação do mercado de torta).

"Houve um avanço extraordinário na tecnologia de produção de mitho que dobrou o rendimento durante a Segunda Guerra. Consequentemente, a demanda americana ocupou cada vez menos e menos áreas A soja moveu-se sobre as áreas deixadas li vres e sobre áreas ocupadas com aveia, feno e pastagens duran te a Segunda (iuerra. A baixa no preço de mercado do milho jun tamente com programas govemamentais destinados a reduzir a oferta de grãos alimentícios fez a soja atrativa como produto alternativo no Meio-Oeste. Adicionalmente, variedades de soja melhoradas e técnicas produtivas continuaram a expandir o limite geográfico onde a produção era possível".

O Meio-Oeste dos Estados Unidos é a maior re -

(18) HOUCK, RYAN a SUBOTNIK - "Soybeans and Their Products Markets, Models and Policy - University of Minnesota Press, Minneapolis, 1972, p。 6. 
gião do mundo na produção do milho. Desse modo passou a ser a principal área de produção mundial de soja do ponto de vista físico e biológico.

Para o sul, em direçẽo do Delta do Mississipi a soja ocupou áreas previamente ocupadas com algodäo e reas de expansẽo agrícola.

Para o norte, na direção dos lagos e das planí cies centraie, a soja tambén substitul outros grãos e áreas de pastagem. Também aí, a política governamental de restrição de áreas plantadas com algodão e outros grãos, e os preços bei xos, estimularam a produção de soja.

Por outro lado "a soja nẽo requereu processos de produção e equipamentos de manejo especializados. Em muitas re giões pôde ser acrescentada aos padrões agrícolas vigentes nas fazendas sem um desembolso maciço de capital.

0 avanço técnico na fabricação das rações permi tiu obter um crescimento acelerado dos animais com uma quanti. dade menor de ração por ganho de peso (19).

$\Delta$ grande aceitação eliminou rapidamente os exce dentes. Cresceu o número de fábricas de alimento composto a ra animais, con uma mistura de torta de soja (rica em proteína e um outro cereal rico em calorias quase sempre o milho, be

(19) $43 \%$ mais rápido para os porcos e $49 \%$ mais rápido para frangos e talinhas. 
neficiando-se da existêncià de preço mínimo para a torta preços liberados para alimentos compostos.

A integração vertical. pela indústria de proussemento de Sçãos até o alimento composto criou o monopólio da ração animal que só poderie ser adquirida pelos criadores como alimento composto e não mais como grãos e tortas (em grandes volumeg).

0 avanço da integração deu-se em direção a um controle completo da produção, principalinente na avicultura on de aparece a "integração contratual", hoje bastante expandida. no mundo todo.

Através desse sistema são celebrados contratos entre as empresas monopolísticas de meios de produção no se tor (avicultura, bovinos confinados, pequenos animais), chama das integradoras e pequenos produtores despojados de meios de produção modernos, chamados integrados.

O produtor integrado adquire a quase totalidade dos neios de produção (animais jovens, equipamentos de cria ção como gaiolas, alimentadores, etc. ), construção de edifí cios para criação e para ammazém edrogas de uma empresa e re vende a produção à mesma firma, no fim do ciclo produtivo.

O produtor integrado oferece apenas a mão-de-obra. Em geral, mesmo os capitais de investimento são oferecidos pela integradora.

Por força do contrato o integrado assume todos 
os riscos da produção, controle sobre o cumprimento do contrâ to pela integradora. No que se refere $\dot{a}$ qualidade das rações e eficiência dos medicamentos, põenas mãos de integradoras - poder de controle do volume de produção em face das reações do mercado, pela variação da compra e qualidade dos insumos fornecidos, sem correr riscos, e garantido por proporcionar lucro compatível com os interesses do setor.

Têm (as integradoras) como ganho adicional o fa to dque tais contratos não implicam em encargos sociais ou cus tos salariais, diretos ou indiretos podendo seu capital sar aplicado em atividades mais lucrativas.

As integradoras estão ainda em condições de impor un ritmo de reposicáo de equipamentos que impossibilita a amortização, tornando o produtor eternamente preso a elas pe Ios contratos.

Analisando as características do integrador con tratual, principalmente na avicultura (19) constata-se um desenvolvimento nas áreas mais pobres e de alta rotatividale de mão-de-obra: no sul dos Estados Unidos, onde os brancos po bres (rednecks) cultivam algodão, e na Europa, tem-se a Bretanha, as zonas pobres do sul e do leste da Hoilanda e da Bélgica.

A guerra teve um papel decisivo na cultura

e destinação da soja.

O preço garantido (de 1941 em diante) favore

(20) BERIAN et alIii, op.cit., p. 316 . 
ceu o rápido crescimento da área cultivada e da produtividade ('crescimento de $22 \%$ da área de sustentação em 1942 féz : pro gredir a área em 50\% e a produção em 75\%). A mobilização de to da a capacidade de trituração existente faz crescer as quan tidades processadas em $58 \%$.

Depois de 1945 ocorreu uma pequena retração na área plantada mas a superfície colhida em grãos para moagem e a exportação cresceu. A superfície para forragens e pastagens diminuiu consideravelmente.

A indefinição dos anos 1930 sobre a destinação da soja está plenamente superada em 1945. Ela se define como oleaginosa com finalidades industriais.

A Tabela 1.9 demonstra o comportamento do pe ríodo onde ocorre tal definição.

TABBELA 1.9 - EVOLUÇÃO DAS AREAS COM SOJA DURANTE E NO PÓS-GUERRA NOS ESTADOS UNIDOS

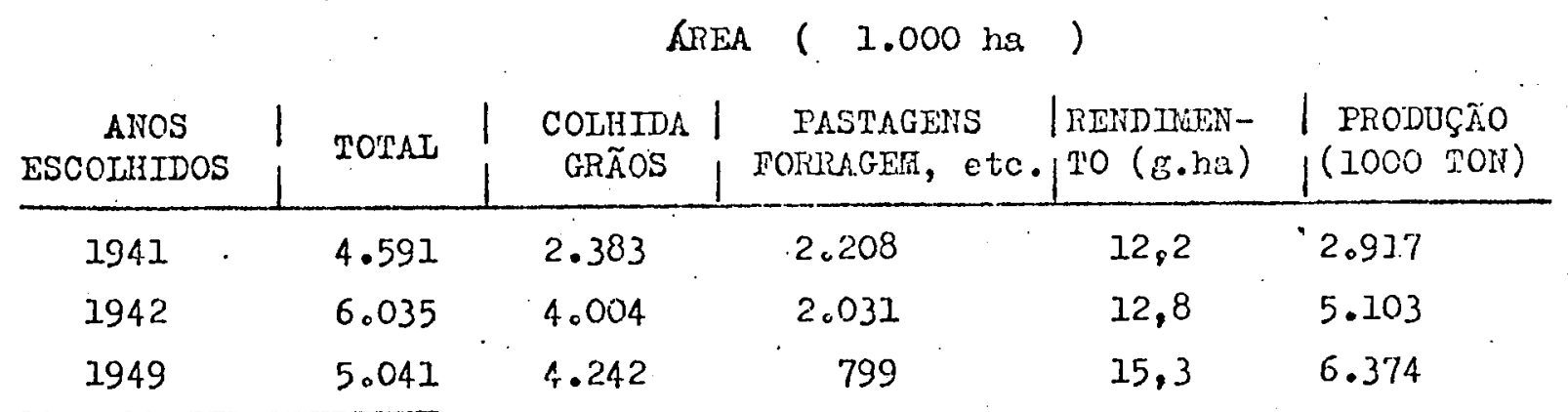

FONIT: BERIAIN et allii, op.cit, p. 316. 
No período de pós-guerra a preocupação da A.S.A. e do "complexo soja" então formado é a consolidação do mercado interno, o que se fez através de leis protecionistas da so ja e seus derivados.

Caem as regulamentações que limitam o uso de "margarinas" na alimentação humana e as taxações ao nível da indústria.

Por outro lado crian obstáculos ao seu alcance para a entrada de óleos tropicais, ao mesmo tempo que tomam as medidas necessárias garantidoras da colocação dos produtos de soja no pós-guerra.

2.2.4 A reestruturação do mercado mundial de produtos primários ("commodities")

A Segunda Guerra Mundial representou uma interrupção de quase todos os fluxos comerciais de antes da guer ra a destruição de fontes de formecimento como plantações etc, a inutilização, em muitos países, das unidades fabris processa doras.

Durante a guerra foram estabelecidos fluxos de emergência inclusive para alimentos e muitos países privados de fontes fornecedoras tiveram que criar alternativas inter nas para seu próprio suprimento e/ou exportação.

A realidade vigente durante a guerra abriu cami. 
nho a produtos que não conseguiam colocação no mercado mundial modificando a composição de grupos de "commodities" no mer cado pela nova condição de competição que adquirirem.

Os Estados Unidos foram o maior formecedor de a limentos durante a 2 Guerra. Os produtos da soja e os grãos entraram no mercado mundial estabelecendo novos fluxos e ga nhando competitividade em condições de demanda interna e ex terna em forte expansão.

Com exceção do Japão, onde grande quantidade de soja é consumida diretamente como alimento, a demanda da soja expressou-se quase inteiramente pela procura dos seus dois sub-produtos principais - óleo e torta.

Oleo e torta são sub-produtos principais resultantes do processamento de diversas oleginosas, obtidas em quantidades mais ou menos fixas para cada uma delas como de monstra o quadro abaixo:

TAB. 19 A CONTEUDO DE TORTA E ÓLEO COMO PORCENTAGEM DO PESO DAS PRINCIPAIS OLEAGINOSAS \% MÉDIA PRODUZIDA POR PESO

\begin{tabular}{lcc} 
OLEAGINOSA & TORTA & OLEO \\
\hline Amendoim & 58 & 42 \\
Algodão & 46 & 18 \\
Iinho & 64 & 35 \\
Girassol & 68 & 31 \\
Copra & 35 & 64 \\
Palma & 52 & 46 \\
Brassica & 58 & 40 \\
Soja & 80 & 17 \\
\hline
\end{tabular}


Um problema que se coloca para as processadoras dessas oleaginosas é que embora ao nível industrial sejam sub -produtos ("joint-products") ao nível da comercialização óleo e torta compõem erupos bastante distintos de "commodities" com comportementos independentes no mercado.

Dessa forma a integração vertical que encontrou facilidades de se formar desde o nível do produtor direto até a processadora (indústria) encontra dificuldades de coordenação a partir dá, muito embora essa coordenação tenha ocorrido e tenha sido decisiva na formação do "complexo soja".

De um lado o óleo de soja forma no grupo de gor duras e óleos de diversas origens (22) e aplicações onde vai competir e de onde sofre impactos na formação de seus preços de mercado com reflexos nos preços pagos ao produtor direto de grãos (agricultura). De outro lado a torta de soja forma no grupo "das tortas protéicas de diversas origens ${ }^{(23)}$ onde compe te e vai sofrer também impactos na formação de preços de mercado com reflexos independentes nos preços pagos aos agricultores.

Vários trabalhos tem demonstrado a forte correlação positiva entre preços a nível do agricultor e área plan tada nos Estados Unidos. Dessa forma a manutenção dos volumes produzidos depende dos preços de suporte, administrados nos Estados Unidos por uma agência govermamental, a Commodity

(22) óleo de peixe, manteiga, banha, óleos vegetais, etc... (23) oleaginosas, farinha de peixe, cereais. 
Credit Corporation (C.C.C.), quando os preços caem abaixo do preço mínimo. (24)

Tendo em vista a desvinculação dos sub-produtos de soja a nível de mercado os Estados Unidos tiveram que montar uma estratégia de colocação desses produtos atuando diferentemente em diversas regiões do globo e criando uma política protecionista no mercado interno.

As primeiras medidas foram tomadas em relação ao mercado interno, onde a A.S.A. coordenou um trabalho de der rubada das restrições à aplicação do ólto de soja na fabricação de margarinas para alimentação humana. Isto conseguido,ga rantiu a eliminação da taxação para as margarinas produzidas nos Estados Unidos.

En 1947 os próprios produtores de margarina se unem à A.S.A. e boicotam as matérias primas estrangeiras em favor do óleo de soja. Outros expedientes são usados para impedir a entrada de óleos vegetais tropicais e o mercado inter no fica totalmente protegido, as margarinas substituindo a man teiga a nível de consumidor final.

\subsubsection{Eventos políticos nos mercados de pós-guerra}

Durante a guerra e nos anos imediatos, o comércio internacional de gorduras e óleos foi parcialmente contro

(24) preços-mínimos para a soja ao nível de produtor foram es tabelecidos nos. Estados Unidos desde a 2 Guerra Mundial. 
lado tendo em vista o atendimento dos países que apresentavam déficits críticos. As quotas de importação e exportação de alimentos, incluindo gorduras e óleos, foram administradas pelo "International Emergency Food Committee" operado sob os auspí cios do grupo "Aliado" até 1947 quando a recém-criada "Food and Agriculture Organization" (F.A.O.), orgão da ONU, assumiu essas funções.

Até 1949 a participação americana foi realizada pela obtenção de licenças emitidas a empresas privadas pelo Departamento de Comércio para a alocação è exportação de . sụ primentos。

De abril de 1948 a junho de 1952 os Estados Tni dos conduziram um programa de ajuda direta à Europa Ocidental conhecido como "plano Marshall", através do qual as nações en volvidas foram providas de dólares a fim de adquirirem produtos essenciais para reconstrução e alimentos, entre os quais gorduras e óleos comprados pelos canais comerciais existentes.

Esse programa financiou exportações americanas de gorduras, óleos e oleaginosas nas seguintes proporções estimadas: $75 \%$ das gorduras, $60 \%$ dos óleos e $12 \%$ das oleagino sas nos anos fiscais de 1949-51. (25)

Foi responsável também pela recuperação da capa cidade de trituração das usinas concentradas na Holanda e Ale manha Ocidental, estabelecendo as bases para a instalação dos

(25) HOUCK et allii, op. cit., p. 26. 
processos americanos de fabricação de alimentos compostos para criação.

Esses estabelecimentos, complementados por acor dos, serão, na década de 1960, as "cabeças-de-ponte" para a atuação do complexo soja americano na recém-criada comunidade européia (MEC) para a introdução dos sistemas de alimentos com postos americanos $(26)$.

Nesse momento a soja americana substitui a soja proveniente da China antes da guerra bem como os óleos tropicais, provenientesdo Pacífico (copia e palma) cujas plan tações foram destruídas ou danificadas pela guerra.

Os Estados Unidos que antes da guerra eram im portadores de gorduras e óleos passam à posição de maior ex portador no pós-guerra.

A União Soviética e a Europa Ocidental emergem como grandes exportadores de óleo de çirassol, enquanto a Chi ne a a India (27) passam a orientar sua produção para o merce do interno.

As oleaginosas passam a ser a maior fonte mundi al de óleos alimentícios. Grande parte da produção organizada na Asia e África enquan zo colônias européias.

Com a independênçia política essas ex-colônias

(26) o sistema "milho-soja" de ração.

(27) amendoim e algodão。 
continuaram a fornecer seus produtos às antigas metrópoles go zando de leis preferenciais de comércio, o que é o último obs táculo americano para o domínio do mercado de gorduras e óleos.

A colocação das tortas proteicas ainda foi um problema no pós-guerra imediato. Em 1954 o Congresso americano vota um projeto de ajuda alimentar aos "povos amigos", o "Agricultural Trade and Development Assistance Act" comumente chamada Public Law 480 (P.I. 480).

Essa lei permitiu a montasem de uma estratégia de concessões a países subdesenvolvidos pelá venda a longo pra zo, vendas não conversíveis em dólares ou doações e outrosti pos de arranjos provenientes do bi-laterais para excedentes alimentares americanos (cereais, óleos), enquanto os excedentes de torta são vendidos para os países desenvolvidos que incrementaram a montagem de sistemas de produção de carnes com ani mais confinados (primeiramente aves e porcos e mais tarde bovinos).

Esse expediente permite enfrentar a ameaça de crise de super-produção sem os problemas que sobrevieram à Primeira Grande Guerra. Em 1956 é criado o "Soybean Council" reagrupando organizações profissionais da indústria e agricul tura com a finalidade de pesquisar os nercados estrangeiros que devem ser "desenvolvidos, promovidos, abastecidos, assistidos, sustentados e protegidos" ${ }^{(28)}$ com fundos da PI 480 (29) $^{(29)}$

(28) BERLAN et alli, op. cit.

(29) BERLAN et allii, op. cit. 
A manutenção de "transferências" de alta porcentagem dos esto ques de óleo - entre 50\% e 90\% até 1971 - pelos mecanismos da PI 480 teve destacada atuação na manutenção dos preços de suporte tanto quanto os estoques reguladores da CCC.

A atukção seletiva no mercado através da PI 480 tem uma função de "dumping" sobre as áreas produtoras de óleos tropicais. A análise regional revela uma forte substi tuição por óleos de diversas fontes (americanos e de outras re giões) e uma substituição do óleo doméstico pelo óleo importa do.

Na década de 50 as oleaginosas se tormaram

a principal fonte de gorduras e óleos, enquanto os produtos marinhos, animais e de palma declinaram de importância.

Essa tendência foi o resultado de vários fato res entre os quais (a) demanda crescente de tortas de oleaginosas (30) mais que proporcional à demanda de óleo (b) menor custo de produção de um quilo de gordura vegetal em relação às gorduras de origem animal, principalmente leite, tendo em vis ta a existência de preços de sustentação através dos governos de diversos países; (c) avanços técnicos no refino do óleo, possibilitando a sua aplicação na fabricação de margarinas e óleos comestíveis; (d) aceitação pelo consumidor final de max garinas" e outros produtos graxos de origem vegetal, sob a crença de proteção à saúde ${ }_{i}^{(31)}(e)$ o suprimento e comercialização

(30) Ver Tabela 1.11

(31) As campanhas publicitárias apelam geralmente para a qualidade das gorduras vegetais na prevenção e controle de doenças cardio-vasculares. 
de óleos de origem marinha e de palma sofreu baixas pela destruição das plantações na época da guerra, e exploração preda tória e desaparecimento dos cardunes de anchovas.

A Tabela 1.10 abaixo dá uma idéia da atuação se letiva através da P.I. 480 na colocação de óleos em 1966-67.

\section{TABEIA 1.10 - DXXPORTAÇÕIS COMERCIAIS E DA PJ 480 AGREGADOS POR REGTÓES.}

\begin{tabular}{ccc} 
& $\%$ & $\%$ \\
REGIOES & EXPORTAÇOES & NAOO \\
COUERCIAIS & COMERCIAIS(PL 480) \\
\hline
\end{tabular}

Mediterrâneo (a)

Países desenvolvidos (b)

Europa Oriental

Países em desenvolvimen to:

América Latina

Ásia e Africa

8

8

8

19

0

14

FONTE: HOUCK et allii, op. cit, p. 250 .

(a) Itália, Espanha, Grécia, Turquia, Marrocos, Argélia, Tunísia - óleo de oliva.

(b) Bélgica, Dinamarca, Finlândia, Islândia, Suécia, Suiça, Reino Unido e outras Austrália e Nova Zelândia.

da Europa Ocidental, Canadá, 
Os grãos e tortas são exportados para países de senvolvidos como mostra a Tabela 1.11 abaixo:

TABEIA 1.11 - EXXPORIAÇÕES AMERICANAS DE SOJA E PRODUTOS DA SOJA POR REGIOES EM PORCENTAGEM DAS EX PORTACÕES TOTAIS AMERICANAS POR PERIODOS SELECIONADOS

\begin{tabular}{|c|c|c|c|c|c|c|c|c|c|}
\hline \multirow[b]{2}{*}{ REGIOES } & \multicolumn{3}{|c|}{ GRÃOS } & \multicolumn{3}{|c|}{ TORTAS } & \multicolumn{3}{|c|}{ OLEO } \\
\hline & $\begin{array}{c}1955 \\
a \\
1956\end{array}$ & $\begin{array}{r}1964 \\
a \\
1965\end{array}$ & $\begin{array}{r}1972 \\
a \\
1973\end{array}$ & $\begin{array}{c}55 \\
8 \\
56\end{array}$ & $\begin{array}{c}64 \\
\mathrm{a} \\
65\end{array}$ & $\begin{array}{c}72 \\
a \\
73\end{array}$ & $\begin{array}{c}55 \\
\text { a } \\
56\end{array}$ & $\begin{array}{c}64 \\
\mathrm{a} \\
65\end{array}$ & $\begin{array}{c}72 \\
\text { a } \\
73\end{array}$ \\
\hline Países desenvolvidos & 94 & 95 & 93 & 93 & 96 & 97 & $85^{(a)}$ & $33^{(b)}$ & 16 \\
\hline - Europa Ocidental & $(48)$ & $(50)$ & (53) & (40) & (74) & $(66)$ & $(80)$ & $(26)$ & (j) \\
\hline . Japão & $(30)$ & (23) & (25) & (3) & (2) & $(6)$ & - & - & - \\
\hline Países sub-desenvolvi & 6 & 5 & 7 & 7 & 4 & 3 & 15 & 67 & 84 \\
\hline TOTAL & 100 & 100 & 100 & 100 & 100 & 100 & 100 & 100 & 100 \\
\hline
\end{tabular}

(a) $63 \%$ somente para a Espanha.

(b) 18\% somente para a Espanha. 
3. Transformacões recentes nos mercados mundiais de óleos alimentícios e tortas proteicas - a consolidação econômica da soja em termos mundiais

Como resultado da política desenvolvida a par tir de 1954 apoiada principalmente na PL 48q de atuação seletiva nos mercados de torta e óleos), executando preços de "dumping" nos países tropicais produtores de óleos vegetais e no Mediterrâneo junto aos países produtores de óleo de oliva, assiste-se na década de 1960 a uma re-estruturação nos grupos de "commodities" em termos de participação de produtos de vá rias origens.

Sem dúvida nesse período cresce e se consolida a posição do óleo de soja no mercado em detrimento de outros pro dutos tropicais.

0 apoio de PL 480 tem efeito até 1973. Depois desse ano a demanda intemacional já suporta preços de livre comércio, tendo em vista principalmente a desorganização das fontes produtoras tropicais (Africa e Asia, principalmente)as quais diminuein sua oferta, e, a crise alimentar.

Quanto à torta, fornecida principalmente para o Japão e Europa Ocidental tendo em vista a "internação" do modelo americano de criação (32) confinada para aves, porcos e bovinos, passa a ser substituida pelo equivalente-torta, isto 
é, passa a ser iroportada como grão com a instalação simultâ nea de empresas americanas de processamento, por investimentos diretos em vários países (Alemanha, Holanda, Espanha, França).

Desde 1962 as exportações do óleo de soja na for ma de grãos (óleo-equivalente) são maiores que as exportações de óleo. Fm 1966-67 as exportações de óleo atingem 25\% do total das exportações com o equivalente óleo. Mesmo assim os Es tados Unidos dominaram as exportações de óleo como óleo. Cerca de quatro quintos do peso do óleo exportado provinham dos Estados Unidos enquanto o restante é óleo produzido com grãos de soja americana importada pelo Canadé, Dinamarca, Alema nha Ocidental, Holanda, Israel e Japão, que utilizam o farelo e reexportam o óleo.

TABELA 1.12 PAISES MAIORES PRODUTORES DE SOJA ENTRE 1965 e 1967

(emmilhões de bushels)

\begin{tabular}{lccccc}
\hline & \multicolumn{2}{c}{ PRODUÇ̃̃o } & & \multicolumn{2}{c}{ ExPORTAÇ̃o } \\
\cline { 2 - 4 } País & Quant. & \% do total & & Quant. \% do total \\
\hline Estados Unidos & 917 & 72 & 246 & 89 \\
China & 252 & 20 & 21 & 7 \\
Brasil & 22 & 2 & 6 & 2 \\
Outros & $\frac{78}{1.269}$ & $\frac{6}{100}$ & $\frac{5}{278}$ & $\frac{2}{100}$ \\
\hline
\end{tabular}

FONTE: HOUCK et allii, op.cit。, p.23. 
TABELA 1.13 - MÉDIA . . DAS EXPORTAÇðES DOS PRINCIPAIS ÓLEOS, TORTAS DE OLEAGINOSAS E OLFAGINOSAS PELOS ESTADOS UNIDOS EM PERÍODOS SE IECIONADOS ( EM 1.000 TON )

PRODUTO

$1950-54$

1960-64

1966-67

OIEOS

- soja

- algodão

- amendoim

$\begin{array}{rrr}115,2 & 550,3 & 521,9 \\ 100,4 & 223,3 & 33,4 \\ 12,7 & 10,6 & 2,3\end{array}$

TORTAS

- soja

- algodão

79,3

$1.128,0$

$2.845,6$

56,8

63,8

3,2

- Iinho

10,8

42,7

83,5

OLEAGINOSAS (GRÃOS)

- soja

915,3

$4.960,3$

$8.368,4$

- algodão

11,3

7,7

4,0

- amendoim

27,3

86,2

75,6

- Iinho

105,6

128,6

211,8

FONIE: HOUCK et allii, op.cit., p. 24.

No fim da década de 1960, 40\% das exportações se faziamsob a forma de grãos.

Se forem comparadas produção e exportação mun dial para diversos óleos e gorduras de diversas origens constata-se uma grande transformação da participação das diversas 
"commoditieg" no grupo con fortue penetração de soja por substituição e expansão. Enquanto a oferta exterma de óleos e de gorduras (compreendendo a soja) crescem de 69\%, a oferta ex terna de óleo de soja cresce de $213 \%$ entre 1955 e 1967.

Juntamente com o óleo de girassol, é o produto cujas exportações mais crescem no mercado mundial. A Tabela 1.14, a seguir, demonstra o comportamento do grupo.

Merece especial atenção a queda das exportações do óleo de amendoim, constando com um percentual de $13 \%$ nas exportações ein 1967 contra 16\% em 1955.

0 amendoim já vinha sofrendo forte concorrência da soja desde a re-valorização da torta pela implantaç̃o na Europa de processios de criação confinada de porcos e aves, grandes consunidores de rações, executada por grandes empre sas americanas dentro do Mercado Comum Europeu via Holanda e Alemanha.

Esse modelo de criação favorece a soja em detrí mento do amendoim pois contém apenas $18 \%$ do volume en óleo en quanto o amendoim apresenta cerca de $50 \%$.

Comparadas as condições de 1967-68 e 1970-71 no Mercado Comum Europeu verifica-se particularmente a queda das condições privilegiadas em que o amendoim do Senegal entra no MCE via França (ex-metrópole). 0 amendoim posto em livre concorrência com a soja americana tem como consequência ime diata uma queda de $24 \%$ contra um incremento de $76 \%$ (cerca de 
BETA 1.14 PRODUÇñO E EXPORTAÇÃO LIUNDIAI DASPRINCIPAIS GORDURAS E OLEC EM ANOS SELECIONADOS

(EH NILHÕES DE TONELADAS E PORCENTAGEI DO TOTAL)

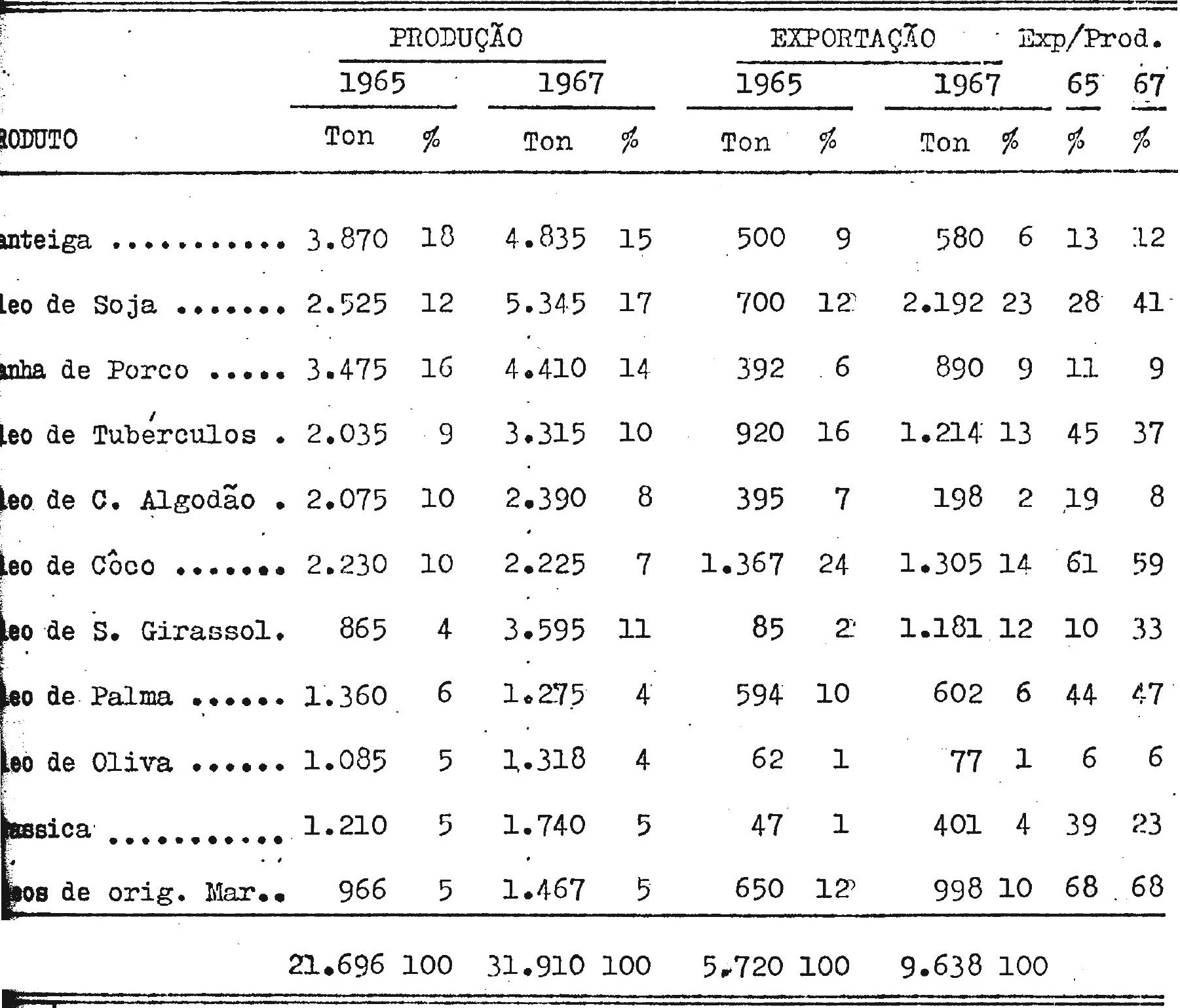


2 milhões de ton) de grãos de soja.

Em condições de concorrêneia diminu 1 o preço de compra do amendoim e a produção cat para menos de $50 \%$ entre $1967-68$ e 1970-71.

Outros países protecionistas do MCE (principalmente Itália) acabam acatando políticas mais liberais que a tingem o mercado de óleo de oliva e a colza, desestruturando rapidamente a produção.

Entre os países mediterräneos, a Grécia e o Mar rocos tornam-se importadores de óleo de soja para misturar ao óleo de oliva e baratear o custo do produto no mercado consumidor.

A Espanha e a Franca acolheram usinas de trituração tormando-se importadores de grãos de soja e exportado res de óleo. (33)

O MCE e O Japão são os maiores importadores de grãos e tortas americanos como mostra a Tabela 1.15 a seguir:

(35) Na França, O grupo Iy.sieur aliou-se com a Cargill e Bun gue para a construção da primeira usina de trituração na França com a garantia de domínio de $60 \%$ do mercado interno. 
TABEIA 1.15 - EXPORTAÇOES AMERICANAS DE GRÃOS E TORTAS DE SOJA PARA O MERCADO COMUM EUROPEU E O JAPÃO

\begin{tabular}{lrrrr}
\hline & $1958-59$ & $1964-65$ & $1972-73$ & $1973-74$ \\
\hline GRÃOS & & & & \\
- Totais en 100 ton & 2.858 & 5.774 & 13.048 & 14.750 \\
- \% do MCE & $33 \%$ & $34 \%$ & $39 \%$ & $43 \%$ \\
- \% do JAPÃO & $34 \%$ & $23 \%$ & $25 \%$ & $18 \%$ \\
TORTA & & & & \\
- Totais em 100 ton & 465 & 1.847 & 4.306 & 4.987 \\
- \% do MCE & $27 \%$ & $60 \%$ & $54 \%$ & $58 \%$ \\
\hline
\end{tabular}

FONTE: BIRLAN et allii, op.cit., p.330.

\subsection{Formaç̃o do mercado para a torta}

0 mercado mundial de tortas proteicas e farelos também sofreu uma re-estruturação nos anos 1960, sendo sua pe netração mais difícil para a soja.

Assim mesmo houve um incremento de $226 \%$ da oferta de torta de soja no mercado enquanto a oferta total do gru po teve um incremento de $162 \%$, com a queda de participação de quase todos os produtos, como o apresentado na Tabela 1.16 a seguir. 
TABELA 1.16 PRODUÇĀO E EXFCRTAÇAO DE FAREIOS OIEAGINOSOS EAR EERIODOS SEIECICNADOS.

$$
(1975-1977)^{(a)}
$$

\begin{tabular}{|c|c|c|c|c|c|c|c|c|c|c|c|}
\hline \multirow{2}{*}{\multicolumn{2}{|c|}{ PRODUTO }} & \multicolumn{3}{|c|}{ PRODUÇÃO } & \multicolumn{4}{|c|}{ ELPORTAÇÃO } & & \multicolumn{2}{|c|}{$\begin{array}{l}\text { EXPORTAÇÃO COM } \\
\text { DA PRODUÇÃOO }\end{array}$} \\
\hline & & 1955 & $\%$ & 1967 & $\not 5$ & 1955 & $\%$ & 1967 & $\not$ & $\begin{array}{c}\not \% \\
1955\end{array}$ & $\begin{array}{c}\% \\
1967\end{array}$ \\
\hline Farelo & Soja & 10.5 & 20 & 23.0 & 24 & 3.0 & 19 & 9.8 & 24 & 29 & 43 \\
\hline 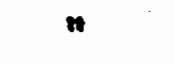 & Algodão & 6.0 & 11 & 7.0 & 7 & 0.8 & 5 & 1.2 & 3 & 13 & 17 \\
\hline$n$ & Amendoim & 2.4 & 5 & 3.6 & 4 & 1.0 & 7 & 2.3 & 6 & $4 \dot{2}$ & 64 \\
\hline$n$ & Girassol & 1.2 & 2 & $3 \cdot 3$ & 3 & 0.1 & .5 & 0.8 & 2 & 8 & 24 \\
\hline$n$ & Brassica & 1.8 & 3 & 2.6 & 3 & 0.1 & .5 & 0.6 & 2 & 6 & 23 \\
\hline$"$ & Linho & 1.7 & 3 & 1.8 & 2 & 0.5 & $3 \cdot 5$ & 0.9 & 2 & 29 & 50 \\
\hline n & Copra & 1.1 & 2 & 1.1 & 1 & 0.9 & 6 & 0.9 & 2 & 82 & 82 \\
\hline " & Palma & 0.5 & 1 & 0.3 & 1 & 0.5 & 3.5 & 0.3 & 1 & 100 & 100 \\
\hline$"$ & Peixe & 1.3 & 3 & 4.6 & 5 & 0.4 & 3 & 3.0 & 7 & 42 & 65 \\
\hline$n$ & Outros & $\frac{27.0}{53.5}$ & $\frac{50}{100}$ & $\frac{48.0}{953}$ & $\frac{50}{100}$ & $\frac{8.2}{155}$ & $\frac{52}{100}$ & $\frac{20.9}{40.7}$ & $\frac{51}{100}$ & 30 & 44 \\
\hline
\end{tabular}

FONTE: Food and Agriculture - ONU

(a) somente oleaginosas destinadas a esmagamento são incluidas. 


\section{O Processamento industrial}

Existem dois métodos principais de separação do óleo e torta da soja: (a) métodos mecânicos, que consistem em prensas hidráulicas e expelidor-contínuo ( rosca sem fim ) e (b) processos por solventes químicos, desenvolvidos na Europa (a primeira aplicação comercial deu-se ros Estados Unidos em 1936)。

Nos processos mecânicos o óleo é separado do grão esmagado por aquecimento. O material que sobra é convertido em torta. Os processos mecânicos tem a vantagem de poder processar várias oleaginosas.

Nos processos por solvente químico os Grãos depois de descascados (depelados) são mergulhados em um solvente volátil de gorduras - usualmente hexano. O composto em ó leo de soja dissolvido é drenado do farelo. o óleo é obtido pela vaporização do solvente. O farelo é tratado para remover traços do solvente e tostado transformando-se em torta.

A "pele" retirada antes do processo pode ser no vamente adicionada à torta tendo em vista ajustar o conteúdo em proteínas para atender a diferentes solicitações do mercado.

A rápida expansão de todos os setores da indús tria da soja americana depois de 1950 e a incorporação de ino vações técnicas na extração por solventes estimularam a con versão de muitas indústrias esmagadoras. 
0 número de indústrias em 1947 era de 200 usi nas sendo que $70 \%$ de processamento era feito por esses meca nismos, tendo caído para $131 \mathrm{em} 1968$, com 95\% do processamento feito por meios químicos. Apesar da queda do número de usi nas, a capacidade de processamento dobrou sua capacidade en tre 1951 e 1969, e a média de esmagamento cresceu de $28 \%$.no mesmo período, como demonstra o quadro abaixo:

TABEIA 1.17 EVOLUÇÃO NA CAPACIDADE DE PROCESSAMENTO DA SOJA NOS ESTADOS UNIDOS (34)

\section{PROCESSAMENTO EM MILHOES DE BUSHELS}

\begin{tabular}{cccc}
\cline { 4 - 4 } PER fODO & $\begin{array}{c}\text { NÚMERO DE } \\
\text { USINAS }\end{array}$ & $\begin{array}{c}\text { QUANTIDADE } \\
\text { PROCESSADA }\end{array}$ & $\begin{array}{c}\text { CAPACIDADE MÉDIA } \\
\text { DE PROCESSAMENTO }\end{array}$ \\
\hline $1950-1951$ & 193 & 310 & 1.6 \\
$1968-1969$ & 131 & 770 & 5.8 \\
\hline
\end{tabular}

FONTE: HOUCK et allii, op.cit. p. 46-47.

A capacidade individual de cada usina varia bas tante. O limite para as expelidoras mecânicas é de cerca de 30-40 ton. em 24 horas, enquanto usinas por processos de solvente atingem 1.700 ton. em 24 horas.

Do ponto de vista locacional não existe um pa drão bem definido de instalação das usinas; elas obedecem a estratégia de custo do transporte dos insumos e dos produtos. $\overrightarrow{\text { (34) estima-so que e }}$ utilizado $90 \%$ da capacidade anual. 
O transporte dos grãos até a usina é mais bara to que o transporte do óleo e da torta até os mercados. Por outro lado o transporte do óleo é meis barato que o transporte da torta. Dessa forma as usinas tendem a se localizar mais próximas des áreas de produção de alimentos compostos para a-nimais e de ração.

Nas áreas produtivas de algodão estão concentra das å esmagadoras mecânicas que processam também caroços.

Por outro lado, o complexo sistema de transporte da soja e seus produtos centrados historicamente em IIIL nois produzem uma forte concentração de usinas no "Corn Bolt" e na região do Delta.

En geral o processamento por solvente é mais eficiente para a extração do óleo, baixeñdo os custos da usina e facilitando a automatização, baixando os preços e tornando seus produtos mais competitivos.

\section{As diferenças entre o valor médio das vendas} por atacaḍo de um bushel de soja e a média dos preços recebidos pelos agricultores em vários períodos ilustra bem o papel dos novos processos na competitividade do óleo e torta de soja.

PERfODO

$1949-50$

1957-60

1966-68
DIFERENÇA MÉDIA (FM CENTS)

\section{8}

36 
58.

0 quadro abaixo mostra a distribuição das usi nas por regiões amexicanas em 1968:

NOOUNERO TOTAL NUTMERO DE ESMAGADORAS
DE USINAS

\section{CORN BELT}

- Ohio

- Indiana

- Illinois

- Iowa

- Missouri

$\begin{array}{rr}5 & 0 \\ 5 & 0 \\ 13 & 0 \\ 18 & 5 \\ 3 & 1\end{array}$

IAKR STATES

- Minnesota

PLAINS STATES

- Nebraska

$\begin{array}{ll}4 & 2 \\ 4 & 1\end{array}$

- Kansas

DELTA STATES

- Mississipi

- Louisiana

14

4

3

I

- Arkangas

ATLANTIC STATES

- Carolina do Norte

$\begin{array}{ll}6 & 3 \\ 7 & 2 \\ 1 & 0 \\ 1 & 0 \\ 1 & 0\end{array}$

- Carolina do Sul 3

- Delaware

0

- Marylana

0

- Virginia

0

OUTROS

- Tenessee

$\begin{array}{rr}8 & 1 \\ 5 & 4 \\ \frac{15}{131} & \frac{6}{33}\end{array}$

- Texas .

4

- Outros 
Um dos principais fatores de consolidação do mer cado internacional de torta de soja foi a penetração, no mercado europeu do sistema de criação americano: o modelo "milho -soja".

A entrada na Europa teve que vencer resistências tanto ao nível dos grupos processadores de oleaginosas como processadores de cereais (como as organizações de produtores de trigo da Alemanha e da França).

0 modelo americano foi montado sobre os dois produtos produzidos na mesmai área. dos Estados Unidos, por sistema de rotação de terras: o milho e a soja.

Depois de 1930 a expensão do milho híbrido de alto rendimento eliminou praticamente outras variedades na agricultura americana. O processo de seleção obteve ganhos de produtividade mas perdeu teor proteico. Dessa forma a produ ção da soja, na época, sofria forte expansão sobre terras deixadas pelos animais de tração e pelo milho em retração de área, principalmente no Oeste americano.

A associação se deu tanto nos campos de cultura como na produção de alimentos compostos onde a riqueza energé tica do milho se juntou à riqueza proteica da soja.

Por outro lado a penetração de milho híbrido nas 
países europeus (35) sem a contrapartida do desenvolvimento de alimentos ricos em proteínas, criou una dependência que pôde ser coberta pela soja americana que entrou a preço muito baj.. xo, difundindo um modelo agro-industrial americano.

Os setores mais atingilos e modernizaōos são 0 avícola e suinocultura, organizados sub base de integração contratual. Dessa forma o preço da soja é o rreço base para o grupo das tortas. os baixos preços praticados até 1972 permiti ram à soja adquirir essa posição preponderante no nercado.

0 modelo acro-industrial de produtoa compostos para a alimentação animal apresenta limites técnicos para subatituição de uma torta por outra. Por outro lado, a presença da soja é garantida ao nível político corn negociações entre os Estados Unidos e o HCE no sentido da eliminação de barrei-/ ras alfandegárias e mesmo das conaições tarifárias especiais.

\subsection{Os Limites técnicog da substituição de oleaginosas}

Do ponto de vista do conteúdo e qualidade das proteínas, as tortas de origens diversas não substituem umas às outras com facilidade, na produção de alimentos compostos. Principalmente dentro de grandes complexos fabris, com alto grau de automação, onde a proporção de cada elemento do composto $e^{\prime}$ automaticamente controlado segundo as necessidades específicas de cada mercado (avicultura, suínos, coelhos, etc). 
Cada torta apresenta não só porcentagens bastan te diferentes de proteína bruta, como proporção de amino-áci dos e outros nutrientes, como tem características próprias de digestibilidade, paladar, etc,

No quadro abaixo estão apresentadas as porcenta gens de proteína-bruta por peso das principais tortas existen tes no mercado mundial:

TORTA

- soja

- algodão

- amendoim

- girassol

- linho

- copra

- palma

- peixe
\% DE PROTEAHA BRUTA POR PESO

FONTE: HOOCK et allii, op.cit., p. 21

Dessa forma os limites-técnicos são um pouco rí gidos a quanto mais moderna e automática a usina, menos opção e mais dependência ocorrerá no formecimento das matérias primas, o mesmo acontencendo com os países optantes por tais modelos. 
0 aparecimento do Brasil como concorrente impor tante, por volta de 1972 é apresentado na literatura especializada como uma fonte alternativa em condições de crise e flu tuação de preços, principalmente após as negociações do GATT para liberalização das trocas (1971).

Tendo em vista a perspectiva de crise econômi ca e em face das opções apontadas acima, ocorre uma corrida de empresss multinacionais organizadas a jusante e a montante da produção de soja no Brasil.

Também aqui se organizaram as empresas de integração contratual como as já descritas (36), que dominarem vá rias regiões do sul do Brasil, como será visto adiante ${ }^{(37)}$.

4. INECANISMOS DE PRECSOS DE MERCADO

4.1 O mercado interno americano

Os preços de mercado americano resultam em primeira instância da interação entre a quantidade comercializada e a demanda total do mercado, de forma que a área colnida e a produtividade jogam importante papel na formação dos prȩ̧os.

Entretanto em condições de pressão estrutural de oferta, a atuação direta e indireta do governo na formação dos

(36) Coradini,0.I., Frederic, A., "Agricultura, Cooperativas e Multinacionais". - Zahar - Rio de Janeiro - 1982

(37) Ver capítulo 6 
preços de mercado tormou-se o principal mecanismo na formação dos preços internos e internacionais da soja e sub-produtos.

\section{Como efeito indireto considera-se a manutenção} de programas de restrição de área plantada para outros produtos, o que atua como um subsídio indireto à produção da soja que pode ser oferecido no mercado a preços baixos.

Como efeitos diretos podemser citados: (a) pre cos de suporte (ou sustentaçăo) ao nível do agricultor e (b) a retirada de excedentes do mercado via mecanismo da PL 480.

\section{O preço de suporte}

O preço de suporte é um mecanismo de adiantamen tos aos agricultores na forma de empréstimos para sustentação dos preços-mínimos decretados anualmente pelo ministro da A gricuitura.

o preço mínimo é estabelecido a nível nacional e uma taxa local de adiantamento para os agricultores é calcu lada próxima ao preço mínimo, calculado com diferenciais de transporte e levando-se em conta o comportamento histórico de cada área.

A taxa de suporte de soja está também ligada ̀̀ taxa de suporte do algodão para evitar a competição no mercado.

A taxa de suporte regulada por lei não é obriga 
tória. Em geral lança-se mão dela quando os preços de merca do estão abaixo do preço mínimo.

Após as colheitas, os produtores vendem a soja no mercado ou estocam a produção obtendo por isso preços de sustentaçäo através de adiantamentos (empréstimos), segundo as taxas locais de suporte.

Em caso de preços em alta os produtores vendem os estoques no mercado livre e então pagam os empréstirnos de suporte ao governo.

Em caso de preços em baixa podem conservar os adiantamentos e entregar a safra ao governo em pagamento.

Atualmente a manipulação das operaçẽes e esto ques é feita por uma agëncia governamental a "Commodity Credit Corporation" (CCC) que adninistra os preços de sustentação decretados.

Adquire estoques reguladores atuando no mercado para manutenção dos preços de sustentação e se desfaz dos esto ques quando os preços de mercado atingem 10\% acima do preço médio de suporte,mais o custo do transporte.

As compras de soja pelo govermo, mantêm os pre ços em períodos de grande produção quando a oferta de grãos ultrapassa em muito a capacidade de processamento - em geral de setembro a novembro. 


\section{O papel da $\mathrm{PI} 480$ no mercado interno}

A utilização da PI 480 para exportação de excedentes de óleo de soja e algodão permitem, ao longo dos anos, a ampliação da demanda por óleos vegetais em termos mundiais.

Entre 1954 e 1971, de 50\% a 80\% do óleo de soja produzido nos Estados Unidos foi exportado por esse mecanismo garantindo a presença do óleo americano no mercado mundial e sustentando os preços do mercado intemo a nível do agricul tor, pela eliminação de excedentes.

Dessa forma garantiu a área plantada com efei tos indiretos sobre a organização da produção agrícola americana, permitindo um crescimento equilibrado, atenuando as crises de super-produção.

Por outro lado, tendo entrado \&. preços muito bai xos através de acordos bi-laterais, principalmente em países tropicais, exerce o papel de "dumping" sobre os produtos ole aginosos tropicais, contribuindo assirn para dificultar o desenvolvimento agrícola desses países em bases nacionais. (38)

4.2 Mercado Mundial

Os preços internacionais da soja e sub-produtos

(38) 1954 foi mostrado o papel de PL 480 na substituição dos óleos de origem tropical pelo óleo de soja... 
estão Iigados aos preços americanos, porque os Estados Unidos dominam o mercado mundial em termos de volume oferecido e estrutura de comércio.

Os mecanismos de preços intermacionais não se dão pelo livre-comércio, mesmo se for levada em conta a não intervenção direta do governo americano nas exportações.

Altas ocasionais nos preços são reflexo de frus tração de safras americanas como a ocorrida em 1975.

Os re equilíbrios em face das variações de ofer ta são possibilitadas pelos estoques reguladores do governo e das empresas privadas; tendo em vista que as usinas estocam na entre-safra de $20 \%$ a $30 \%$ de sua capacidade de trituração es tima-se que os estoques nas mãos de particulares nos Estados-Uniảos nesses períodos é de aproximadamente 1,6 milhões de bushels.

Os mecanismos intermos desencadeadores da forma ção de preços está representado no gráfico a seguir.

4.3 Reflexos dos preços da soja no comportamento de outros "commodities"

O comportamento do preço da soja reflete-se sobre o comportamento de outros produtos com os quais compete no mercado. 


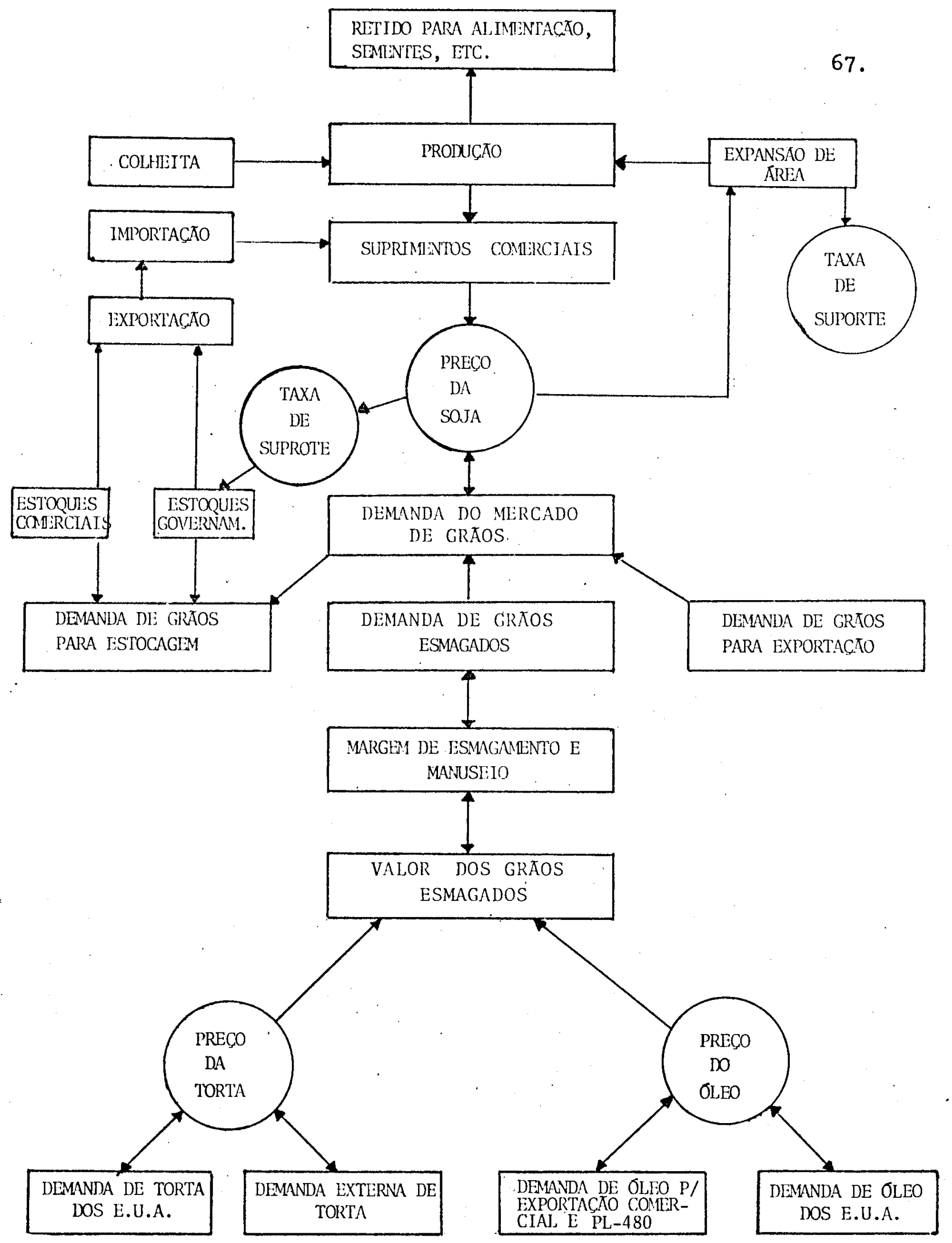

GRAF。 I Demanda e estrutura de preços do Mercado Americano de Soja. As flechas indicam direção de maior influência. 
Os coeficientes de correção $(r$ ) entre preços 1951-67 - da soja e produtos de soja e preços de vários óleos e tortas calculadas por HOUCK et allii (1972) mostra o seguin te:

PRODUTOS COMPARADOS EM PREÇO

$r$

- torta de soja $x$ óleo de soja

$+0.03$

- torta de soja $x$ torta de linho

$+0.68$

- torta de soja $x$ torta de amendoim

$+0.53$

- óleo de soja x torta de soja

- óleo de soja $x$ óleo de amendoim(a)

$+0.03$

- óleo de soja x óleo de algodão

$+0,78$

- óleo de soja $x$ óleo de girassol

$+0,75$

$+0.90$

- soja x torta de soja

$+0,83$

- soja $x$ óleo de soja

$+0,35$

FONTE: HOUCK et allii, op.cit., p.

(a) Preços de 1950-1966.

1. Há correlação maior eintre os preços dos produtos da soja e aqueles com os quais elas com petem do que entre os sub-produtos ( "joint products") de soja, provavelmente pelo des vinculamento dos preços (preços de sustentatação do óleo pelo P.L 480);

2. Há maior correlação entre os preços do óleo de soja com seus concorrentes do que entre a torta de soja e seus concorrentes, possivel - 
mente porque a capacidade de substituição en tre óleos é mais alta do que a capacidade de substituição entre tortas. (39)

3. A variação dos preços dos grãos de soja está mais ligado à variação dos preços da tortado que do óleo. A soja em grão e as tortas se destinam a países desenvolvidos temperados, sem alternativas atuais de produção de proteínas em grande escala,os quais internalizaram a indústria de alimentos compostos e o modelo americano de criação. Essa dependên cia é suprida num mercado razoavelmerte li vre.

Quanto aos óleos, como já foi dito destinok-se (até 1971) aos países tropicais subdesenvolvidos a preços sub sidiados não refletindo nas flutuações da demanda(entre $50 \%$ e $80 \%$ pela PL 480).

5. Perspectivas de mercado

\section{Demanda potencial}

Uma enálise regional da expansão potencial da demanda demonstrou em termos agregados o seguinte comportemen to:

(39) Ver item 3.4 - os Iimites técnicos da substituição de oleaginosa 


\begin{tabular}{|c|c|c|c|c|}
\hline \multirow[t]{2}{*}{ REGIXO } & \multicolumn{3}{|c|}{$\begin{array}{l}\text { CONSUMO ENI POUNDS } \\
\text { PER CAPITA POR ANO }\end{array}$} & \multirow[t]{2}{*}{$\begin{array}{l}\text { EIASTICIDADE } \\
\text { DA DEMANDA }\end{array}$} \\
\hline & $1962-63$ & 1975 & 1385 & \\
\hline $\begin{array}{l}\text { 1. PAfSES DESENVOLVIDOS } \\
\text { - países econ. centr. } \\
\text { - países em desenvolvimento }\end{array}$ & $\begin{array}{l}38.9 \\
13.0 \\
10.3\end{array}$ & $\begin{array}{l}41.6 \\
17.6 \\
12.5\end{array}$ & $\begin{array}{l}43.1 \\
21.6 \\
15.0\end{array}$ & $\begin{array}{l}- \\
-\end{array}$ \\
\hline $\begin{array}{l}\text { 2. PAISES DESENVOLVIDOS } \\
\text { - América do Norte } \\
\text { - Comunidade Européia } \\
\text { - Outros países da Europa Ocidental } \\
\text { - Austrália e Nova Zelándia }\end{array}$ & $\begin{array}{l}44 \cdot 7 \\
51 \cdot 3 \\
37 \cdot 2 \\
40 \cdot 9\end{array}$ & $\begin{array}{l}44.2 \\
54 \cdot 3 \\
39.2 \\
40.3\end{array}$ & $\begin{array}{l}44.2 \\
56.5 \\
40.0 \\
39.8\end{array}$ & $\begin{aligned} & 0.0 \\
+ & 0.2 \\
+ & 0.2 \\
- & -\end{aligned}$ \\
\hline 3. EUROPA ORIENTAI & 36.7 & 40.3 & 43.1 & - \\
\hline $\begin{array}{l}\text { 4. PAfSES EM DESENVOLVIMENTO } \\
\text { - América Central e do Sul }\end{array}$ & 18.3 & 20.2 & 22.9 & +0.4 \\
\hline $\begin{array}{l}\text { 5. AFRICA E ASIA } \\
\text { - Africa } \\
\text { - Oriente Niédio } \\
\text { - Extremo Oriente }\end{array}$ & $\begin{array}{l}9 \cdot 2 \\
9.2 \\
8.8\end{array}$ & $\begin{array}{l}10.6 \\
11.0 \\
11.0\end{array}$ & $\begin{array}{l}12.5 \\
13.2 \\
13.9\end{array}$ & $\begin{array}{r}- \\
+0.9 \\
+0.9\end{array}$ \\
\hline 6. JAPÃO & 11.9 & 22.0 & 33.2 & - \\
\hline
\end{tabular}

HoUCK et allii, op.cit. 
Como se pode ver claramente a capacidade de absorção pelos países desenvolvidos está esgotada,constando como mercado potencial principalmente a Ásia.

Tendo em vista a necessidade de equilibrar a ba lança de pagamentos e diminuir o endividamento extemo vários países tem produzido e exportado alimentos para os países desenvolvidos em detrimento da alimentação humana interna.

A América Latina produz e exporta sorgo e soja em detrimento de produtos alimentares. A Árica continua a ex portar produtos de alimentação animal para a Europa (torta, a mendoim) em detrimento da alimentação local. Estima-se que na crise de seca e fome de 1971-73 os oito países do Sahel (Etió pia, Alto-Volta, Mali, Mauritânia, Nigŕria, Senegal, Sudão e Tchad) continuaram a exportar de dois a cinco vezes mais proteínas do que importavam. (40)

Em geral, durante a década de 1970 as exporta ções de alimentos e forrageiras no chamado mundo sub-desenvol vido aumentou mais rapidamente que a produção alimentar in terna como. demonstram os seguintes dados agregados:

(40) cf. VERGOPOULOS, K. - I'agriculture periphérique... p. 16. Tiers Monde, $t$ XXII, ne 85, 1981. 
TABELA 1.19 - TAXAS MÉDIAS ANUAIS DE VARIACÃO ENTRE (1970-1977) EM PORCENTAGEM

\begin{tabular}{lccc} 
REGIOES & $\begin{array}{c}\text { PRODUÇÃO } \\
\text { ALIUENTAR }\end{array}$ & $\begin{array}{c}\text { EXPORTAÇÖES } \\
\text { ALIMENTARES }\end{array}$ & $\begin{array}{c}\text { EXPORTAÇOES } \\
\text { FORRAGEIRAS }\end{array}$ \\
\hline Africa & 1,3 & 10,56 & 8,53 \\
América Latina & 3,4 & 17,30 & 30,94 \\
Extremo-Oriente & 2,9 & 20,44 & 19,25 \\
Oriente-Próximo & 3,5 & 12,75 & $-2,21$
\end{tabular}

FONTE: FAO - La situation mondiale de l'alimentation et de I'Agriculture em 1978, Roma, 1979.

Alguns autores referem possibilidades de subs tituição da torta de soja na Europa com ganhos de proteína pe la aplicação de uréia na ração.

A uréia produziria os ácidos-aminados necessári os na fase de ruminação. Evidentemente esta tecnologia desde que absorvida, poderia libertar os países temperados do jugo da soja, mas só no que se refere à alimentação de ruminantes.

A avicultura e a suinocultura bastante desenvol vidos na Alemanha, Benelux e França não poderia dispensar esse tipo de torta.

Por outro lado a expansão do mercado de proteínas nos países desenvolvidos já atingiu seu limite. A tecnolo gia "de ponta" hoje é a extração de proteínas para consumo huma no direto, desde que a proteína animal está atingindo custos 
muito altos.

A produção de 1 quilo de proteína animal é conseguida '́ custa do consumo de 7 a 10 quilos de proteína vegetàl. A aplicação da soja para consumo humano direto elimina ria a criação como fase obrigatória da cadeia alimentar humana.

Não se trata entretanto de introduzir hábitos a limentares milenares ou seja o consumo da soja e de seus sub-produtos de preparo doméstico. Trata-se de introduzir uma no va etapa de consumo controlado pelo "complexo soja" pela apli cação de tecnologia avançada de extração de proteínas para fâ bricação de leites tipo "Ionga-vida" farinhas, etc...

Os Estados Unidos detém o monopólio dessa tecno logia no momento, existindo pesquisas no mesmo sentido sendo feitas sob os auspícios da Nestlé e da Unilever (4I).

As aplicações industriais possíveis são as se guintes: (a) enriquecimento de alimentos de origem animal com baixo teor proteico;

(b) substituição em parte das farinhas panificá veis e das carnes industrializadas (salsi.chas, etc...)

(c) Fabricação de produtos dietéticos

(d) a cobertura dos déficits proteicos dos países sub-desenvolvidos.

(41) c.f. BERLAN, op.cit., p.326. 
A problemática da substituição proteica esbarra em complexas questões técnicas e comerciais. De un lado o de senvolvimento de processos de extração, concentração, trans formação, embalagem e venda, do outro a monopolização dos conhecimentos técnicos guardados sob patente.

A pesquisa de processos por si só não garante a independência a nível de empresa ou país. A montagem dos sis temas de máquinas e estrutura empresarial para colocar o produto no mercado exige investimentos vultosos.

A conquista dos mercados que representa a imposição de novos hábitos alimentares já foi posta em marcha.Tan to em países desenvolvidos como em países sub-desenvolvidos. A estratégia se coloca pela penetração dos produtos por via institucional: restaurantes, cantinas, hospitais, forças-arma das, escolas, (42) que tendem a se tormar "mercados cativos" das grandes empresas multinacionais pela mobilização do apare Iho de Estado.

"Solicitando na Conferência de Munique a abolição das normas que impedem a incorporação das proteínas da soja nos produtos destinados à alimentação humana, os Estados Unidos afirmam sua vontade de adquirir uma posição dominante nos sistemas alimentares e não indústrias de indústrias agrícolas dos países europeus, de acelerar a evolução para uma alimentação industrial e levar a termo o controle dos sistemas agro-industriais europeus". 43

(42) por exemplo a "vacamecânica" .

(43) BERLAN et allii, op.cit。, p. 328. 
Os mercados potenciais aparecem ainda (a)nos países sub-desenvolvidos que consomem farinhas proteicas atra vés de ajuda alimentar; (b) segmentos muito pobres da população de certos países cujo consumo é controlado por super-mercados das empresas onde trabalham (mineiros da Bolívia, Chi le e Africa do Sul).

5.1 O advento da soja brasileira no mercado mundial

Quando a literatura especializada indicava 0 pleno domínio americano no mercado mundial da soja, o Brasil comparece no fim da década de 1960 como um produtor importante fazendo crescer sua produção de trinta vezea entre 1965 e 1980 , crescenco sua participação na produção mundial de cerca de $1,5 \%$ em 1965 para $18 \%$ em 1980 .

Esse fato provoca uma "corrida" para o Brasil de um grande número de empresas multinacionais atuando a ju sante e a montante da produção agrícola às quais se juntam al gumas empresas nacionais que haviam crescido em bases seme Ihantes às estrangeiras antes do período referido.

Hoje constata-se no Brasil o domínio da "coorde nação vertical" ou quase-integração.

Por outro lado a atuação dessas empresas no mer cado de grãos e derivados se dá através de escritórios espe cializados e estabelecidos no Brasil, os quais atuam no con trole de preços e nas cotas de exportação, tendo em vista a 
falta de estrutura interma capaz de orientar os produtores em direção dos melhores lucros. Na verdade essas vendas eram aim ples operações de transferência. (44)

Dessa forma o mercado brasileiro de soja emerge ologopolizado e manipulado externamente, sendo provável a ten dência ao alinhamento às condições imperantes no mercado mundial.

5.2 Os. sistemas alimentares na "ordem do dia"

A década de 1970 foi marcada pela discussão, em diversos níveis, sobre as formas de contormar a crise que teve lugar por volta de 1960 e tomou contornos bastante definidos na década seguinte.

Por um lado apresenta-se como uma crise técnica de super-produção do ponto de vista das metrópoles (queda da taxa de crescimento econômico, desemprego, enquanto para os países não desenvolvidos aparece como uma redução progressiva da capacidade de importação.

(44) C.f。 o Deputado Rospide Neto ao abrir o I simpósio Na cional da Soja em 1975 em Porto Alegre, dizia: "a soja em grão e seus derivados eram comercializados por empre sas multinacionais ou estrangeiras... sabe-se que essas empresas foram responsáveis por $80 \%$ da exportação de so ja, nas quais figuravam como compradora do produto, havendo muitos casos nos quais a compradora mandava colo car na própria guia de exportação o "NOTIFIED" que è uma recomendação a quem deverá ser entregue o produto"I Simpósio Nacional da Soja - Assembléia Legislativa do Rio Grande do Sul, 1975, p. 16. 
Pela primeira vez na história uma crise se dá com uma alta de preços permanente e estrutural no mercado mun dial.

"A explicação desse fenômeno novo, consiste no fato de que, graças à estrutura monopolística, a produção e o mercado se esforçam pela alta dos preços para recuperar o que perdem tendo em vista a estagnaçăo relativa dos mercedos in termacionais".(45)

No plano global trata-se de uma dificuldade crescente de países do chamado "Terceiro Mundo" de se desenvol ver no nesmo ritmo dos países de capitalismo avançado.

Crise do balanço de pagamento, aumento da dívida externa, um serviço da dívida absorvendo quase todas as receitas de exportações, desvalorizações sistemáticas de moe das nacionais como forma de enfrentar o problema são as carac terísticas generalizadas nos países sub-desenvolvidos não exportadores de petróleo.

Dentro desse panorama de discussão da crise de 1970 nos grandes foruns mundiais, a questão se coloca como una necessidade urgente de reordenamento intermacional para a recuperação da competitividade intemacional.

Nessa linha de proposta aparecem temas como in dustrialização seletiva pela construção de sistemas nacionais (45) VERGOPOULOS, K. op.cit., p.8. 


\section{de produção.}

"As novas políticas buscam fundar novos siste mas produtivos valorizando os ganhos econômicos absolutos em relação ao mercado internacional." (46)

Isto significa produzir a um custo menor que ou tro concorrente en termos mundiais.

Dentro das tendências atuais de ordenamento eco nômico defende-se a liquidação deliberada de setores econômicos tradicionais em benefício de novas especializações industriais que possam realmente ser vistas como ganhos absolutos, a "dívida extema funcionando como um mecanismo fundamental de financiamento para a reconversão das estruturas produtivas existentes para nov as especializaçôes".

Esse modelo industrial crescendo voltado para o exterior necessitaria de um re-ordenamento do setor agrícola, pela criação de sistemas produtivos nacionais, voltados para a alimentação de uma população urbanizada e operária.

Os sistemas produtivos nacionais vieram substituir setores agrícolas tradicionais voltados para o mercado ex temo de bens primários buscando a diversificação em uma base nacional.

"Oombater o déficit alimentar pela reconversão das estruturas agrárias tradicionais em estruturas produzindo

(46) idem, p. II. 
para o mercado local - intemo e regional - constitue um obje tivo fundamental para a política agrícola atual no quadro da busca de competitividade industrial internacional" ${ }^{(47)}$.

"A autosuficiência alimentar nacional faz parte da nova ordem econômica intemacional". (48)

"O progresso do sistema econômico urbano necessita do estabelecimento de novas relações agricultura/indús tria e modificações na estrutura das demandas locais para os produtos agrícolas:

.a) troca das demandas internacionais tradicionais de matérias primas por demanda(crescen te ) de produtos de consumo alimentar;

.b) troca da especialização agrária (as vezes monocultura) pela diversificação (montagem de um sistema compondo policultura/pecuária)

.c) crescimento do exército industrial de reser va junto às grandes centros urbanos e indus triais;

.d) redução dos custos sociais do trabalho e do custo social de funcionamento do sistema comprimindo a renda agrícola.

(47) idem, p. 16.

(48) c.f. UNCTAD - Arusha Programe e FAO Agriculture:Horizon 2000,1979 . 
6. TRANSFORMAÇOES DOS PROCESSOS PRODUTIVOS NO SUL DO BRASII E a PENETRAGÃO DO "COMPLEXO SOJA"

A história da adoção de inovações técnicas na agricultura do sul do Brasil, conta com a presença do arroz irrigado no Rio Grande do Sul, o qual de forma precoce, inten sifica a aplicação de maquinários na agricultura, aproveitando rendosamente as únicas terras "Iivres" de um espaco fortemente monopolizado pela propriedade privada da terra.

É bem conhecida a diferenciação que se faz entre a colonia, representada pela pequena propriedade policultora, lugar privilegiado das cooperativas de agricultores, e a Campanha, terra de campo dedicada à criação.

São áreas depuradas por dois processos historicamente distintos de povoamento, como bem demonstrou N. Ber nardes $(49)$, para o qual "não é difícil estabelecer para o território rio-grandense uma divisão regional em que às zonas geográricas naturais, correspondam geralmente ceracterísticas culturais homogêneas" (...) No Rio Grande do Sul, os adenga mentos rurais elevados, ficam condicionados a $85000 \mathrm{~km}^{2}$, ou pouco mais. Aí regiatram-se altos índices de crescimento de população, mesmo nas áreas de ocupação mais antiga (...) dessa forma, persistindo a dualidade econômico-social, ela impõe

(49) BERNARDES, No Bases Geográficas do Povoamento do Es tado do Rio Grande do SuI - Boletim Geográfico Ne 17 e 172, IBGE, Rio de Janeiro, p. 12 . 
ao Rio Grande um contraste demográfico que se tem acentuado progressivamente" ...

Compreendendo essa dualidade como correspondente às condições naturạis distintas, campos e matas, conclui que o progresso do povoamento havia cessado, barrado que esta va pela monopolização da terra. O adensamento da pequena propriedade nas matas e a pecuária extensiva, e o quase vazio hu mano nos campos.

"O luso-brasileiro via no europeu recém-chegado - agricultor, para quem não havia mais terras de campo onde se estabelecer, e ele não poderia vir roubar, com suas lavouras;o espaço destinado ao gedo"( 50 )

A decadência econômica da pecuária, os excedentes populacionais coloniais urbanizados, a tradição mecânica dos alemães e italianos, a oferta de crédito agxícola e a demanda crescente de arroz, foram fatos que se superpuserom para a ocupação das terras livres do Rio Grande - as várzeas inundáveis do Jacuí e da orla litorânea.

E com efeito o arroz irrigado que inicia o processo de rompimento dessa dualidade, depois de 1920. E a forma de penetração da agricultura e do arado na estância depauperada.

Os altos rendimentos permitem desde essa época,

(50) idem. 
a extração de altas taxas de renda fundiária de $11 \%$ até $30 \%$ do valor da produção ( 51 ).

Máquinas e implementos invadem a orla dos cam pos; os gauchos deixam os galpões para se transformarem em motoristas e tratoristas, a população urbana aventura-se. 0

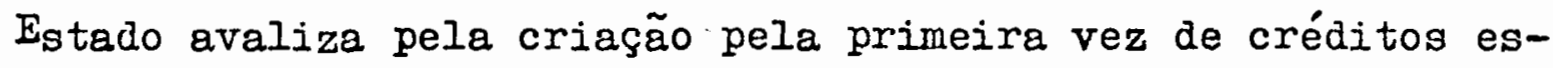
peciais à agricultura (CREAI, em 1937) - Ver Tabela 1.20.

Se o sistema de expörtação da carme bovina foi fundamental para a articulação da lavoura arrozeira com os mercados,pelo uso das ferrovias e dos terminais marítimos, o arroz foi fundamental para a adoção de processos produtivos me canizados para o trigo, que embora fosse conhecido e cultivado no Rio Grande do Sul, não o era em grande escala, ficando restrito à propriedade colonial como o demonstra E.F. Teixei$\mathrm{ra}(52)$

entretanto a nível político, pelo amparo e orientação do Estado que a situação se modifica, sendo o trigo, a única cultura agrícola atendida nos programas de substi tuição de importações.

(51.) V. PEBAYLE, Po Eleveurs et Agriculteurs du Rio Grande do Sul (Brésil): Université de Iille III, 1974.

( 52 ) 'Teixeira, E.F. "O Trigo no sul do Brasil" - Ed. Linotype, São Paulo, 1958. 
TABELA 1.20 MRQUTHAS E TITLEMENTOS PARA A LAVOURA ARROZEIRA NO RIO GRANDE DO SUL ENG 1944/1945, $1959 / 1960$ E

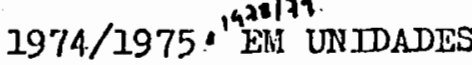

\begin{tabular}{|c|c|c|c|c|}
\hline \multirow{2}{*}{ ILQUUTAS I IMTLEWBNTOS } & \multicolumn{4}{|c|}{$A N O S$} \\
\hline & $1941 / 1945$ & $1959 / 1960$ & $1974 / \%$ & $78 / 79$ \\
\hline Trutores e Microtratores & 807 & 5.405 & 12.720 & 16.705 \\
\hline Loconóveis & 1.049 & 393 & 305 & 127 \\
\hline Hotores a explosẽo & 449 & 2.080 & 3.424 & 3.465 \\
\hline Hotoress elétricos & & 19 & 404 & 597 \\
\hline Bombas de recalque d'água. & 1.607 & 3.465 & 5.143 & 4.880 \\
\hline Trilhadeiras & .1 .390 & 2.277 & 2.450 & 1.044 \\
\hline Automotrizes & & & 2.921 & \\
\hline Secadores mecûnicos & 242 & 401 & 1.043 & 1.122 \\
\hline Someadeiras mamais & 1.717 & 2.612 & $2 . .283$ & 1.473 \\
\hline Semeadeiras mec。a lanço & & 650 & 1.608 & 1.358 \\
\hline Semeadeiras meco en linha & & 77 & 199 & 227 \\
\hline Semeadeirg.s adub。 a lanço & & & 1.420 & 3.159 \\
\hline Semeadeiras adub. em linha & & & 1.493 & 1.738 \\
\hline Adubadeiras a lanço & & & 91 & \\
\hline Adubadeiras em linha & & & 235 & \\
\hline Aracios a boi & 15.464 & 18.023 & 9.047 & 4.175 \\
\hline Arados a disco a trator & 116 & 2.191 & 6.765 & 9.003 \\
\hline Arados de aiveces a trator & 293 & 11.348 & 4.804 & 5.717 \\
\hline Gradea de disco a boi & 4.725 & 4.267 & 1.710 & 537 \\
\hline Grades de digco a trator & 618 & 4.554 & 13.128 & 16.928 \\
\hline Grodes de dentcs a trator & 72 & 2.078 & 5.793 & 7.154 \\
\hline Grades de dentes a boi & 4.485 & 5.018 & 1.176 & \\
\hline Grades de Lladeira & 1.714 & 972 & 74 & \\
\hline Carretas(trator/tração animal) & 5.849 & 5.790 & 3.342 & 2.168 \\
\hline Carroças . & 1.640 & 2.063 & $\because$ & \\
\hline Carroções & 1.642 & 3.166 & & \\
\hline Reboques(trator/tração animal) & & 1.475 & 6.094 & 8.177 \\
\hline Carretas graneleiras & & 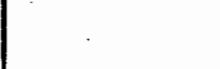 & 620 & 3.226 \\
\hline Aplainadoras de solo & & & 914 & 1.488 \\
\hline Valetadolras mecânicas & & & 540 & 845 \\
\hline Intripadeiras mecânicas & & & 2.632 & 4.175 \\
\hline Combinadas & & & & 4.4 .52 \\
\hline Motoniveladoras & & & . & 58 \\
\hline
\end{tabular}

FONTE: BORTOLUZI, C.R.D. - "Análise de Fatorca Associados a ́́rea é Produção do Arroz no Rio Grande do Sul, Porto Alegre, 1978, mimeo. 


\subsection{Efeitos da política de substituicão de importações}

Uma breve história da produção tritícola no sul do país localiza a primeira política atual de apoio ao trigo

em 1534 (53). Sua introdução no Rio Grande do Sul em 1749 foi feita pelos colonos vindos dos Açores, entretanto deixaram de plantá-1o depois que sucessivas safras foran frustradas.

As políticas de pós-guerra estão ligadas a uma série de decretos federais dos últimos anos da década de 1930 estabelecendo incentivos financeiros para os produtores de tri go e a instalação de estações experimentais federais destinadas a sustentar e estimular o cultivo do trigo ( 54 ).

Em 1944 foi criado o Serviço de Expansão do Tri go (SET) para trabalhos de fomento e o IPEAS - Instituto de Pesquisas e Experimentação Agropecuárias do Sul, em 1945 (estabelecido em Pelotas) para realizar pesquisas tritícolas.

Nos primeiros anos após a Segunda Guerra Mundial os preços de importação do trigo eram muito altos e o trigo nacional era adquirido livremente pelos moinhos, mas os pre ços em baixa e a taxa de câmbio fixa, que vigorou em 1950 1951, tormaram o trigo importado bastante atrativo, o que tor nou obrigatório o estabelecimento de quotas de importação, às

(53) V. CUNHA BAYMA, Trigo, Volumes I e II, Rio de Janeiro, (Serviço de Informação Agrícola) Ministério de Agricul tura, 1960).

(54) rf. KNIGHT, P. Substituição de importação na Agricultua ra brasileira: A produçäo de trigo no Rio Grande do Sul. 
quais eram estabelecidas pelo SET, vinculadas às quantidades de trigo nacional moído.

"Sabe-se que o trigo e a sója são mais e mais cultivados no Rio Grande do Sul: ... por outro lado, esquece-se de assinalar que essas grandes quantidades provém em maio ria, não mais das pequenas explorações coloniais, mas de um tipo novo de estabelecimento agrícola que, por sua localiza ção nas planícies de pecuéria tradicional, por seu tamanho e pelos sistemas de cultivo é un pouco a réplica, em terra de "coxilha", do estabelecimento rizícola das "várzeas": uma "granja" "( 55 )。

Tendo em vista que os preços do trigo doméstico, tornou-se mais caro que o importado, para os moinhos ocupando um sistema de preços múltiplos, toda a sorte de fraudes - conhecidas na literatura como fraude do "trigo papel" tendo entretanto, servido para a expansão da área tritícola mecanizada.

Essa expansão corresponde à penetração do trigo nas áreas de campo, mecanizáveis, favorecidas por um processo de concessão de crédito a taxas de juros reais negativos, por subsídios aos fertilizantes e maquinaria agrícola.

Nos primeiros anos da década de 1960, com o lan çamento do Programa Nacional do Trigo, teve início uma expan são acelerada, tendo como suporte para o melhoramento das prá ticas culturais e comercialização por um sistema de cooperatị

(55) Pebayle: R.- Eleveurs et Agriculteurs au Rio Grande do Sul (Brésil). Universite de lille - Nimeo. 
vas de produtores de trigo, encorajada pela Comissão de Com pra do Trigo Nacional (CTRIN) do Banco do Brasil, que é o úni co comprador do trigo brasileiro desde 1962.

P. KNIGHT relaciona em una Tabela a média do preço c.i.f. de importação que o Brasil pagou pelo trigo es trangeiro desde 1947 a 1969, considerando que representam a parte relevante do trigo consumido no Brasil, o qual, após 1955 passou a ser importado quase que só pelos Acordos do Tri go (P.I. 480) celebrados com os Estados Unidos e em menor quan tidade, por acordos bilaterais com a Argentina, e assinala que "os preços do trigo eram mais altos no período imediato a pós-guerra e desde 1955 não tem havido nenhuma tendência nos preços de importação, senão nos últimos três anos..."

A considerações desse tipo, retira-se que " 0 trigo nacional era apresentado como mais caro do mundo, ocultando-se o fato de ser o trigo estrangeiro subvencionado na origem pelos govermos dos países exportadores, e importadocom dólar artificialmente baixo "( 56$)$.

Como os Acordos do Trigo acentuavam pagamento a longo prazo e em cruzeiros, fizeram cair por terra os principais argumentos em favor do Programa Nacional do Trigo.

A união dos triticultores, entretanto, foi sufi ciente para conseguir a denúncia do Acordo em 1958, mas segui

(56) Schilling, P - TRIGO - o trigo e o latifúndio no Rio Grande do Sul - 0 acordo do trigo Norte-Americano Perspectivas da Triticultura gaúcha。 
86.

das frustrações de safra, por problemas climáticos, gerou uma

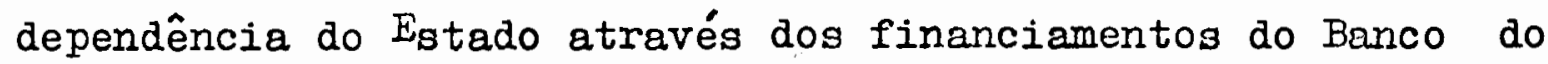
Brasil。

Nessa época os produtores tritícolas reinvindicam uma política econômica mais coordenada e a liberação do crédito como fatores essenciais ao desenvolvimento da agricul tura e particularmente da triticultura, enquanto acendia o de bate sobre a política econômica.

O Instituto Superior de Estudos Brasileiros ( ISEB), pela palavra de $P$. Schilling defendia a auto-suficiênciz em trigo e aprovava medidas essenciais para o equilíbrio de interesses entre produção e consumo.

"Os principais fatores que determinaram a crise em nossas relações de produção-consumo são o monopólio da ter ra, a pressão externa e a exploração dos intermediários; con cluiram que as medidas aplicáveis, perfeitamente exequíveis, mesmo (...) na organização capitalista, seriam estas: reforma egrária, política intemacional independente e abastecimento dos centros de consumo pelas Cooperativas de Produção "(57).

Por outro lado, o citado estudo, apoiado em dados e menções dos Congressos Anuais de triticultores aponta a política cambial adotada, competitiva da importação de máquinas e fertilizantes a baixos preços como anti-agrícolas e im peditivos do cumprimento da meta de auto-suficiência em tri go.

(57) SCHIIIING, P. op.cit. p. 2I (o grifo é nosso). 
Entre 1958 e 1966 a área cultivada em trigo caiu em 39\%, ocorrendo uma evasão de produtores de origem urbana e um avanço temporário da pecuária sobre os campos anteriormente ocupados com o trigo.

A partir da segunda metade da década de 1960 (1967) há uma retomada geral de produção tritícola tanto no Rio Grande do Sul quanto em outros Estados.

A partir de 1966 a área cultivada manteve-se em expansão com relativa diminuição da parte importada na composição do consumo, aparecendo como agentes dessa expansão (a) a política Estatal de economia de divisas, (b) o advento dos triticultores como grupo organizado de pressão política ( as cooperativas) e (c) a falta de outras opções para o cultivo de inverno e (d) a complementariedade da soja que no processo de consolidação da estrutura produtiva torna-se hegemônica. 
Muito embora cultivada convencionalmente no Brasil a partir de 1936 e inclusive com extração de óleo combustível / (1959 no Rio Grande do Sul região do Alto Uruguai) a soja era consumida "in natura" como forrageira na complementação da alimentação de suínos nas pequenas propriedades coloniojis e produzidas em consorciamento com o milho.

Im São Paulo, sua reprodução se deu através dos japoneses em 1908(horticultura para consumo "in natura" e prepa. ro doméstico de diversos alimentos)

Em 1950 tem início trabalho de pesquisa e de fomento pelo Irsstituto Agronômico de Campinas em convênio com a empresa Anderson Clayton, passando dai a registrar pouco mais de quatro mil hectares da área plantada no período de 1952 a 1953.

Também no Paraná sua introdução data da década de 1950. J. Gomes da Silva ${ }^{(58)}$ menciona o plantio de duas mil sacas de sementes "importadas" de são Paulo, cujo cultivo teve co mo objetivo a adubação verde de cafezais afetados pela geada / de 1953.

Com o apoio de empresas interessadas na exportação, foram plantadas cerca de 5 mil sacas nas regiões de

(58) Citado por: Funđação Cargill - " A Soja no Brasil Central", 1977. 
Iondrina Maringá em 1956.

Somente a partir de 1960 entretanto a cultura adquire expressão podendo sex apontados as seguintes regióes pioneiras:

Rio Grande do Sul: Alto Uruguai, Região das Missões, zona. Planalto médio, ( centro do Estado);

Paraná: Londrina, Maringá e sudoeste do estado;

São Paulo: Barretos e Orlândia.

5 entretanto na zona das Missões, no Rio Gran de do sul que teve início o processo de rotação soja-trigo. Essa região dedicada básicamente a pecuária extensiva até a década de 1950, volta-se para a produção do trigo que se expande rápidamente pelas condições de solo e topografia fa vorável à mecanização.

L soja é utilizada como . cultura melhorante, utilizando a mesma maquinaria empregada para a cultura prin cipal (trigo), e os resíduos de fertilizantes.

Do mesmo modo expande-se para a zona central do Estado que se tornou também zona pioneira na adeção do binômio soja-trigo. 
Tendo em vista o aproveitamento do sistema pro dutivo montado para a produção tritícola e e ampliação da atuação das cooperativas, o binômio pôde implantar-se e expandir-se até os limites de latitudes suportadas pela soja.

Graças à demanda internacional crescente e ao mercado favorável aliado à coincjdência da colheita de soja brasileira entre a safra americana; a produção a : custos mais baixos pelo aviltamento do preço do trabalho, a soja brasileira apresentou boas condições de competição no merca do internacional e passou a receber o incentivo do Estado para produção e exportação. Graças a esses fatores, a produ ção de soja cresceu 800\% entre 1970 e 1977 passando de cul_ tura complementar a cultura principal.

o binômio trigo-soja consolidado no Rio Grande do Sul graças inclusive a estrutura das cooperativas, ex pande mais tarde para outras regiões mesmo sem essa infraes trutura de apoio. O fato se deve a fatores de ordem técnica com a falta de opções de cultura de inverno para quase todo - sul brasileiro e por outro lado a total garantia de cultu ra do trigo pelos subsídios estatais e garantia de mercado. - qual amparou a adoção pela supressão dos riscos e ainda :por fatores de ordem econômica com a maior rotação do capi tal fixo (pela produção dë duas safras em um mesmo ano, utilizandoos mesmos equipamentos e processos produtivos técnicamente e socialmente muito semelhantes). 
Com efeito, o grande papel do binômio está na possibilidade de ốbsontara condições de vantagem com"a produtor americano o qual só em regiões muito restrita do sul pode adotar a rotaça por sucessão.

A maior competividade na produção entre áreas, adotantes do binômio ou não, vai ocorrer internamente, onde a formação dos custos é semelhante, separando áreas do binô mio como de mais fácil consolidação nas condições atuais de amparo oficzal e as regiões para as quais não é possível a obteriçõo de duas safras ao ano.

A competição internacional e principalmente entre as condições de produção brasilleira e americana de fine-se favorável a Brasil, unicamente pelo aviltamento do custo de mão de obra, sendo que os Estados Unidos compe tem pelos.preços mais baixos dos insumos e do maquinário, como pode ser observado no Quadro $I$.

Quanto à composição orgânica calculada temos os seguintes índices:

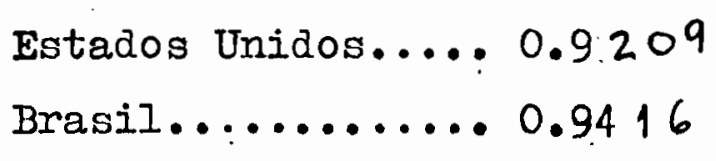

No que se refere ao pagamento de rendas pela utilização do Capital-dinheiro e de terras, temos uma in- 
QUADROI -Dados Comparativos dos custos de Produção Norte Americana e Brasileira. SAFRA: 1975/76.

\begin{tabular}{|c|c|c|c|}
\hline IMEM & & & \\
\hline Inseticidas e herbicída & & 224,52 & $155,4.4$ \\
\hline Sementes & & 217,53 & 160,00 \\
\hline Fertilizantes & & 189,54 & 213,00 \\
\hline Calcáreo & & - & 27,00 \\
\hline Mão de obra & & 126,74 & 76,14 \\
\hline $\begin{array}{l}\text { Máquinas e implementos, } \\
\text { inclusive deprecią̧ão }\end{array}$ & & 529,83 & 653,05 \\
\hline Outros custos variáveis & & 148,35 & - \\
\hline Colheita e secagem & & 164,83 & - \\
\hline Iransporte & & & 20,00 \\
\hline Total/hectare & & $2.360,23$ & $1.417,13$ \\
\hline Rendimento ( $\mathrm{Kg} / \mathrm{ha})$ & & 2.663 .06 & $3 . .575,00$ \\
\hline Custo por tonelada & & 886,30 & 899,86 \\
\hline Total US:/Ton & & 112,1 & 157.8 \\
\hline $\begin{array}{l}\text { Pagamentos de Rendas } \\
\text { Juros, s/Cap. Fixo e } \\
\text { Custos variáveis }\end{array}$ & & & 144,35 \\
\hline Terra & $\mathrm{Cr}^{\mathrm{W}}$ & 1.156 .97 & 258,33 \\
\hline Terra & US\$ & 130,00 & 45,00 \\
\hline
\end{tabular}

Fonte: Adaptado de Fundação CARGILI "A Soja no Brasil Cen tral ! - 1977, p. 16

(a) Dados de American Soybean Association -U.S.A. (b) Dados da Cotrijuí - R.G.S. 
cidência diferenciada sendo que nos Estados Unidos paga-se cerca de 130 dólares. (sendo um fator que pesa mais na produção americana que na brasileira).

Por outro lado, enquanto a incidência docusto dos insumos no custo da produção é de $27 \%$ nos Estados Unidos, para o Brasil esses custos sobem a $4.2 \%$; se forem incluídas as máquinas a incidência nos Estados Unidos sobe para 50\%, e no Brasil sobe parä $88 \%$, demonstrando uma forte diferenciação na composição dos custos, pela adoção dos mesmos processos produtivos. 
7. A INTEGRAÇAO DA REGITO DE ASSIS - SAO FAUIO

7.1 As Bases Naturais da Organização da Produção

o exame do zoneamento climático e da capaci dade de uso do solo, por vários de seus parânetros, permite isolar dols grandes conjuntos para os quais as bases naturais da produção são diferenciais. A prineira, abarcan do cerca de $60 \%$ do território da MRH-Assis apresenta-se apto à agricultura sem restrições a quase todas as culturas temporárias tropicais, indicando muito especiaimenteadição de poder produair soja em rotaçäo com trigo, muito embora indicando deficiência hídrica leve no inverno para este último produto.

A região compete economicamente com as demals áreas produtoras de soja como Barretos e Ribeirão Pre to, onde a rotação em sucessão não é possivel e a soja encontra condiçôes ótimas de desenvolvimento apenas como cul tura única.

0 outro domínio abarcando cerca de $40 \%$ da área da MRH-Assis é constituído por terrenos arenosos, de baixa fertilidade ou terrenos de forte declividade, com problemas de conservação do solo e combate à erosão, sendo especialmente indicados para pastagens apresentando restri côẹs em.pequenas áreas onde só o reflorestamento é indicado. ( v. figura 2.2)

No primeiro domfrico encontram-se os solos mais férteis que se extendem de forma contínua ao sul da região, onde ocorrem solos originados da decomposição de rochas ígneas básicas, a terra "roxa". No centro e ao norte da região ocorrem manchas de terras "roxas" e as chamadas terras "mistas" nas áreas de contacto entre as efusivas básicas e o arenito Bauru. ( vofigura 2.3 ). 
95.

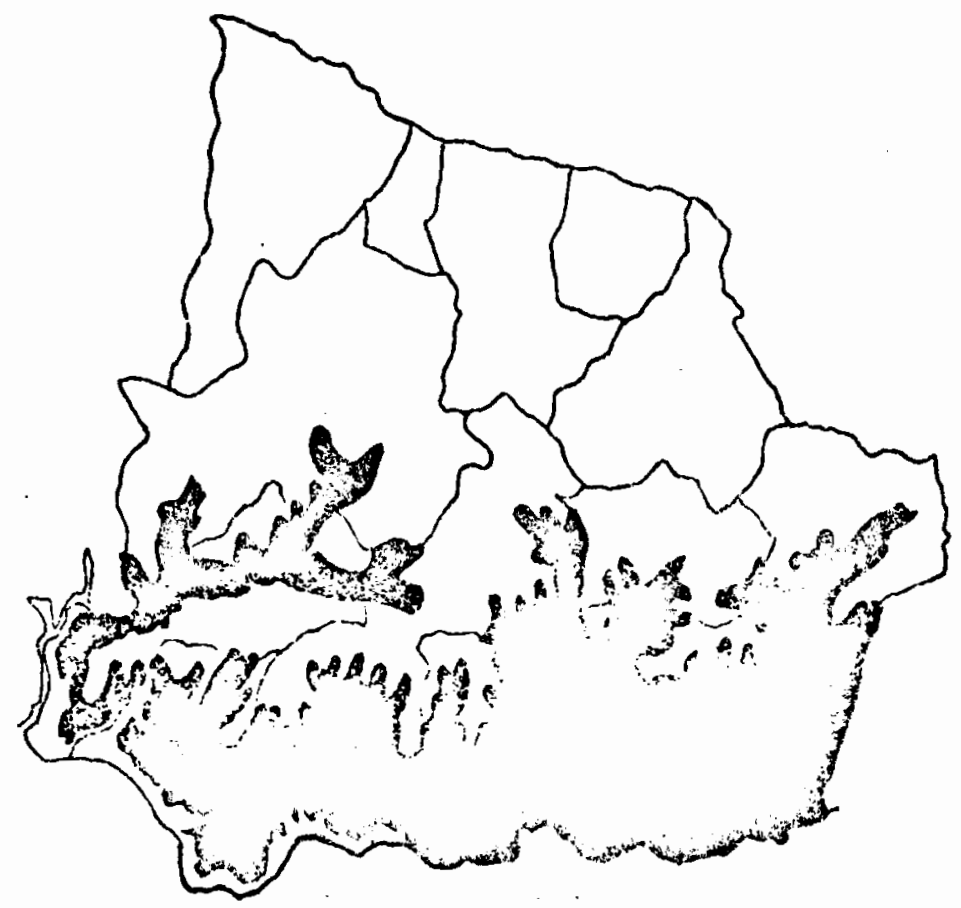

2.2 Figura Dominio da Terra "Roxa" provenien
tes da decomposição de rochas $\div$.

ígneas bāsicas do Grupo Bauru

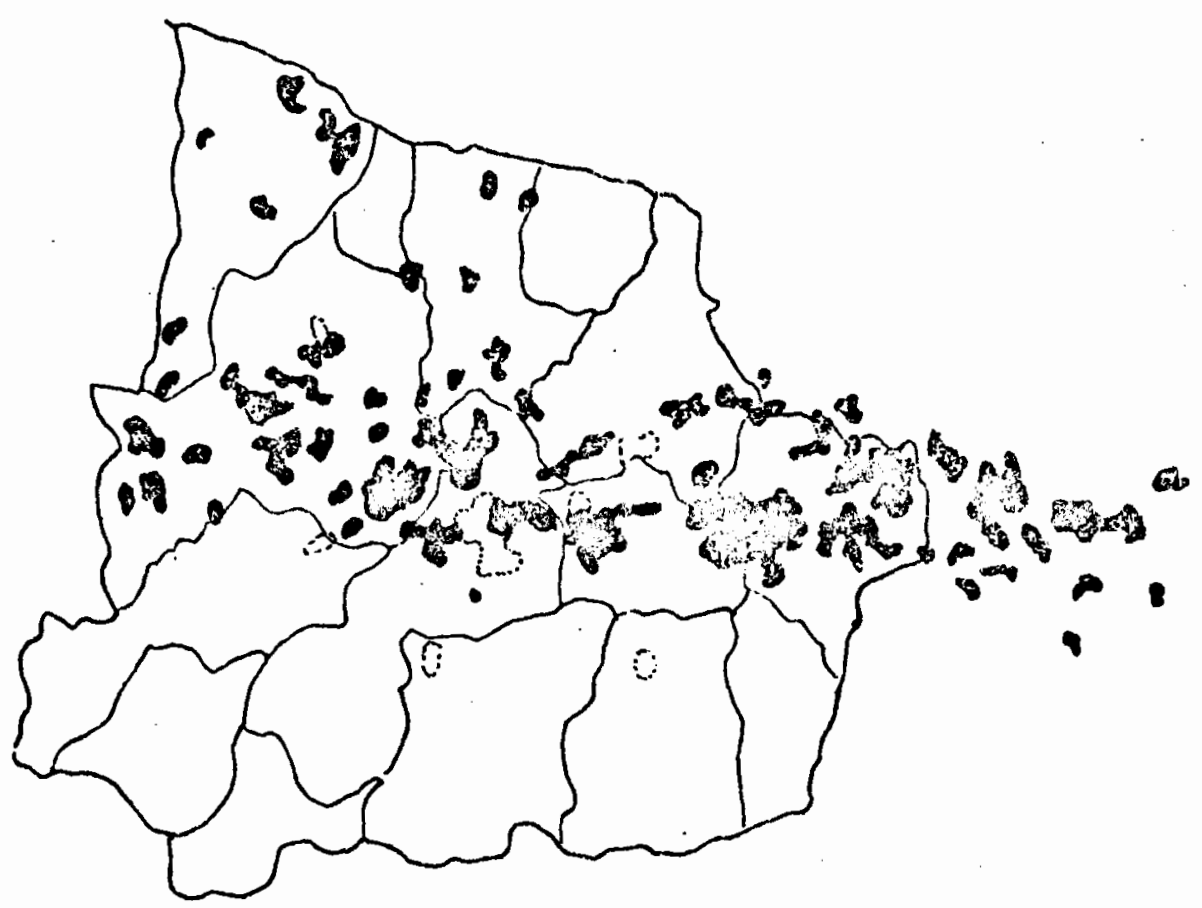

2.3 Figura Resíduos de "Campo Cerrado" no divisor de áquas Paranapanema-Peixe

Fonte: Atlas Regional do Estado de São Paulo, Regional de Marīlia. Governo do Estado, SEP-CAR, 1980 
Tradicionalmente, essas áreas de terras férteis abrigam culturas temporárias como algodão, amenoioim, arroz, mílho e cana, ocorrendo a cul tura do café nos diviso res de águas dos tributários do Paranapanema, onde contudo evitaw os vales, muito propícios ìs geadas.

As terras arenosas do centro e do norte da região (terras "brancas") estão associadas à presença do cerrado e campo, e são utilizadas par pastagens extensivas geralmente em "campo sujo" .

0 padrĩo técnico de produção do "binomio" Soja-Trigo adaptado para a região, utiliza a terra apenas como "suporte" da atividade.

Isto significa que a terra é a base sobre a qual se fixa a planta, sendo suas necessidades totais de nutrientes fornecidas por adubaçōes, independente da variação do grau de esgotamento e/ou fertilidade natural das diversas terras.

Esse tipo de manejo adaptado por razões que serão examinadas mais além, homogeinicam as terras do ponto de vista do potenctal produtivo sendo evidente que essa supercapitalização -forçada- elimina em grande parte a pos sibilidade de obtenção de lucros extraordinários pela exploração das melhores terras.

Essa homogeinlzação entretanto encontra limites, pela capacidade diferencial que os dois grandes domínios acịma referídos têm de incorporar os nutrientes adicionados. Imbora pareça não existirem estudos específicos nesse aspecto, os trabalhos de campo confirmam o comportamento e a diferença desses dois domínios na capacidade de estabilização dos nutrientes. As terras origináriamen te mais férteis, os solos mais argilosos, menos ácidos, incorporam mais rápidamente a matéria orgânica resultante do próprlo processo produtivo (aração da resteva e incorpo ração da palha do trigo e dos resíduos orgânicos da soja) 
e apresentam um comportamento de retenção de nutrientes so lúvels ao longo dos periodos de cultivo, de forma que um bom manejo termina por produzir um solo mais rico em nutri entes, Incorporando ainda nitrogênio pela ação conjunta da adubação e da ação dos rizóbios, sendo portanto a soja uma cultura melhorante.

Quanto ao domínio de terras "brancas" a incorporação é mais dificil tendo en vista o caráter arenoso do solo e as especials condições de migração de colóides ; de forma que a retenção de matéria orgânica e nutrientes é multo baixa ou nula, obrigando à manutenção de altos ingressos em adubos e calagem para a exploração econômica. De forma que pelas proprias condições edáficas, esses domfnios se apresentam bastante diferenciados, explicando os limites de adoção do "binômio Soja-Trigo" o qual é dominan te no sul, juntamente com a cana-de-açúcar.

Do ponto de vista climático, muito embora as maiores restriçōes sejam as geadas e os granizos, que ocorrem dominantemente no sul afetando o trigo, a deficiên cia hídrica acaba por afetar os trigais não com relação ao seu desenvolvimento, mals em face àe propiciar o ataque de larvas do solo que utilizam suas raízes como fonte de água ocasionando uma quebra de safra significativa, como é o ca so da séptoliose.

Saliente-se alnda que a soja é particularmente sensfvel ao fotoperiodismo o qual não sendo adequado diminue ou mesmo impede a floração. Esse carater é limitan te no que se refere a escolha das variecades adequadas é epóca de plantio. 0 plantio na região deve ser efetuado em novembro para as vartedades tardias e início de dezembro para as varledades semi-tardias e precoces para alcancar a floração no período de fotoperiodismo mais equilibra do,o que permitirá produtividade maior e o inf́cio da colhẹi 
ta em março-malo quando ainda ocorrem temperaturas máximas elevadas posgibilitando uma colhelta de grãos mais secos, com níveis de umidade adequada impedindo a delscencia da vagem no pé, responsável pela quebra de até 11\% da safra, quando ocorrem "veranicos "após a maturação dos grãos. 


\subsection{As condições históricas da greanização de produção}

As especificidadeg históricas em que se deu

produção do espaço da região de Assis, torna seu estudo bastan te atrativo e elucidante. Muito embora esteja fora do âmbito deste trabalho a discussão desses processos é neccssírio que se esclarç̧an três aspectos, bastante interligado:s, os quais ten l.evado vários autores a equávocos insuperáveis.

O primeiro diz respeito a origem e ao mecanismo de formação da pequena propriedade, o qual está ligado ao próprio processo de ocupação da região, tendo emergiủo o sítio e a fazenda, não sem lutas e tensões, de jentro das grandes gle bas apossadas e/ou compradas da região.

O sesundo diz respeito ao papel do café na produ ção do espaço regional; muito embora pareça ser generalizadopa ra o Estado de São Paulo o parcelamento da grande propriedade cafeicultora depois da crise de 1929 , este mecanismo não é extensivo a todo o oeste paulista. Parece ser muito mais uma tendência das áreas velhas e restrita a zona "pioneira"da no roeste, e um fenômeno menos corum no Planalto Ocidental paulis ta.

Por un lado, a região de Assis, embora tenha pro duzido café, jamais foi uma zona cafeeira, caracterizando-se pe la produção de cereais e algodão, amendoim e cana de açúcar.

Por outro lado, mesmo antes de 1929 , por razoês 
que não serão explicadas aqui, o café avarı̧a organizado na base da pequena propriedade, cono é o caso da reriäo de Presiden te Frudente.

A região de Assis, embora povoade 3. partir de 1876, esteve marginalizada do espaço produtivo tendo em vista as cjficuldades de ligeça com o nexcado.

A estrada de ferro Sorocabaria, como as demais ferrovias que tiveram un papel decisivo na integraçäo de áreas do coinplexo ciafeeiro, só alcançou a regrião a partir de 1915 , en contrando já as terras esgotadas e a maliza fundiério adensada por cerca de quarenta anos de ocupaça. A estrada avança rapidamente até o rio Paraná, propiciando a plantação do café em terras do espigão central àe Presidente Prudente e Presidente Venceslau, já em 1918.

Por outro lado, o ramal de Cambará no Paraná fez avançar outra frente de expansão das áreas cafeeiras, proyiciando rendimentos difereneiais mais elevados.

O café, portanto, "salta" sobre a regiẽo $\stackrel{e}{\text { somente }}$ mais tarde, na década de 1940 vai ocupar cimeiras das verten tes dos tributúrios do Paranapanema. Até essa época, as matas do Paranapanema, cobrindo grandes extensões de terra roxa (ter ra roxa estruturada) estavam cobertas por matas cuja explora ção nessa década representou uma fonte importante de renda para a região.

0 incremento da pequena propriedade deu-se pela 
Eub-divisão por herança e muito menos por loteamentos, os quais ocorreram entretanto. O ecesso a terra por parte dos produto res foi ficjlitado pelos baixos presos da mesma, que embora férteis, não abrigaram historicanente nenhum produto comercial. importante.

Este fato, aliás, indica que o preço da terra esteve ligado, não aos ratores naturejis em si, mas ao potencial de renda de situação relativa.

Até a cécada de 1950, a produção de alimentos e ra voltada para os mercados locais, estanques. A insuficiência de meios de transporte e o caráter radial das ferrovias paulio tas contribuiran para a produção de um espaço onae a vida de relaçôes efotuava-se ao longo das estrada. A formação àe preços para os produtos alinentares era feita a partir da demanda local sofrendo flutuações de acordo cojn a oferta e regularido a área plantada.

E dessa forme, em breves palavras, que a produ ção agrícola se articula do ponto de vi.ste mercantil.

Iato explica antes de mais nada as características da orçanização de produção na reciano, a qual deve ser entendida não como uma incapacidade de desenvolvimento regional das forças produtivas, mas como um limite en geral de desenvolvinen to, e que só vjeram a se integrar cono áreais produtoras para um mercado nacional de bens primários, a pextir da década de 19501960. 
oferta de trabalho, os quaj.s, considerados muito baixos "ex plicariam" a generalização do cultivo de mantimentos em parceria

(59)

0 advento da parceria e das formas tradicionais de arrendamento é fenômeno recente e devido muito mais ao so bre povaamento da região un condições le mercado específico. .

Se por un lado a parceria é coinmente vista como uma forme não "pura" de extração de sobretrabalho,por oiztro la do, poderá ser compreendida como una forma de pagamento em tra balino pelo acesso à texry e aos demais meios de produção, dentro de un sistema pouco monetarizado.

Num sistema em que a terra esté totalnente monopolizada por constituir-se em propriedade privada, só o exce dente de oferta de trabajho pode explicar a parceria na pequena propriedade, que é a forma cono ela ocorce na MRH - Assis, constituindo-se as "águas" dos muricípios do sul (principalmen te Cânaido Mota e Palmital) em "viveiros" de mão de obra.

A explicação para esse excedente de mão de obra absorvido pelas pequenas e médias propriedades encontra-se na parcial integração da região à produção algodoeira depois de 1930, a qual demandou oferta de mão-de-obra para a colłeita,re crutada inclusive entre urbanos mas principalmente pelo expe -

(59) $V_{\dot{\tau}}$ BRANDT; V.C. "Do colono ao "bóia-fria": Transforma ções na Agricultura e Constituição do Mercado de TrabaTho na Alta Sorocabana de Assis. - Estudos CEBRAP, ne19 1977, p.52. 
diente de recorrer ao Instituto de Migração e Colonização do Estado o qual assumia a tarefa de localização de migrantes nacionais nas lavouras paulistas.

O "surto do algodão" que ocorreu depois da crise de 1929 não pode ser explicado apenas como uma prática de salvamento por parte dos cafeicultores individados, muito embora tenham realmente lanģado mão desse expediente com vistas à recuperação econômica enquanto prodụtores.

As áreas algodoejras por excelência, depois de 1924, foram a alta Noroeste e a Alta Sorocabana de Fresidente Prudente.

A Alta Sorocabana de Assis integrou-se na produção de forma menos intensiva, comportando-se como área periférica aos centros produtores e comercializadores, um a Norte, ou tro a oegte.

- Muito embora a análise das repercussões dessa fa se de integração do espaço paulista à agro-indústria estejam fora dos limites do presente trabalho convém tecer algumas con siderações.

Em primeiro Iugar essa integração em regime ${ }^{d e} l i$ vre concorrência internacional, deu-se por um período muito curto, podendo delimitar-se entre 1927 e 1939 , não ${ }^{\text {se }}$ tendo consolidado, tendo em vista que a Segunda Grande Guerra convul sionou os mercados. 
Eu segundo Iugar é preciso lembrar que correspon dem a uma disputa internocional entre Japao e Inglaterra pela hegemonia nos mcrcados têxteis, que correspondeu a uma forte netarização do setor ocorrida a partir dos países interessados tendo em vista organizar rapidamente a estrutura produtiva vol tada para o setor algodoeiro, os quais evidentemente garantiam as compras.

Essa política induziu a produção pela multiplica ção dos arrendamentos de terra e pela generalização do regine de empreita da colheita, orientando correntes migratórias in ternas para as regiões produtoras, entre elas, a região de Assis.

De forma que o povoamento de amplos setores do oeste paulista se explica pela demarảa de mão de obra pelo algodão, principalmente para a colheita.

Uma análise do incremento da população nas zonas 7 e 8 conforme Camargo $(60)$ e do papei dos mjgrantes nacionais indicam os seguintes dados agregados:

QUADRO

- PORCENTAGEM DE MIGRANTES NACIONAIS SOBIE A POPULACGAO ENTRE 1901 e 1940 (61)

$1901-1920 \quad 1921-34 \quad 1935-40 \quad 1921-40$

ZONA 7

15.0

25.9

40.4

69.8

ZONA 8

27.6

32.8

46.3

74.4

(60) CAMARgo, J.F. de - Crescimento de População no Estado de São Paulo e seus aspectos econômicos - IPE-USP, Ensaios Econômicos no 14, 1981, p.8.

(61) idem, p.43 e 44 . 
Entre 1921 e 1940 a 7 zona recebeu um contingen te de 290.619 migrantes, sendo que 36\% do total entrou depois de 1930; para a 8 zona o contingente entrado no mesmo período foi de 177.067 migrantes, sendo que $43 \%$ entrou depois de 1930 .

Caso fosse possível uma análise menos agregada $\underline{i}$ solando apenas as áreas algodoeiras esses percentuais seriam mais expressivos.

Quanto ao incremento do número de cafeeiros consi gnados à região de Assis, até 1920, 100\% correspondiam ao Município de Echaporã (então Bela Vista) e entre 1934 e 1940 mais de $50 \%$ ainda correspondiam a esse Município(62), mais integrado à formação do mercado de trabalho da região de llarília do que de Assis. Ainda assim, no mesmo período o número médio de pés de café por estabelecimento sempre esteve entre 3 mil e 5 mil pés, característica que se manteve, indicando a presençado café na pequena propriedade.

O cativeiro da mão de obra (liberado pela adoção do "binômio soja-trigo"), definido pela parceria e pelo arrendamento emerge quando a integração agro-industrial se desfaz.

0 algodão em pluma perde posição nos mercados in ternacionais, há uma retração da área cultivada que é substi tuída por cereais e mais tarde também pelo amendoim. 0 processo de desarticulação da região em relação aos processos produtivos organizados a escala mundial, trouxe consigo um retroces so das reḷações de produção, o qual só veio a ser recuperado de pois de 1944 pela introdução da cana-de-açúcar.

(62) Camargo, J. F. de op. ct. 
Na luta contra a "morte" do capital fixo imobili zado na integração da indústria se articula politicamente tentando manter a produção a preços rebajxados enquanto consome seu capital fixo imobilizado.

Este episódio conhecido como o primeiro surto do algodão do planalto paulista é um dos mais bonitos exemplos de produção e desarticulação do espaço de forma integrada aos grandes conplexos monopolistas internacionais.

Indjca também um dos momentos fumbamentais de pro dução do especo o qual na região acaba por reproduzir de forma ampliada a pequena propriedade policultora de un lado, e a média e grance propriedade necuarista de outro.

0 advento de relações de produção mais avançadas - da criação de un cmbrião de mercado de trabalho livre está ligado à presença da cana de açúcar. Implantada na região a partir de 1944 como resultado do esforço de guerra para produção de álcool carburante, teve condições econômicas e políti cas de se consolidar (63). Esse embrião serve de base para a formação do mercado de mão de obra indispensável para a ado-

(63) para melhor compreensão da articulação da região ao complexo açucareiro v. BARRIGUELII, J.C. "Conflito Participação no Meio Rural - a greve da Usina Nova Amé rica (1962) II Encontro Nacional de Estudos Rurais e Urbanos - Cadermos do CERU no 12, São Paulo, 1979; ver também BRAY, S. "A cultura da cana de açúcar no vale do Paranapanema", tese de doutorado, 1980, mimeo;QUEDA 0. "Intervenção do Estado e a Agro-Indústria Açucareira Paulista, tese de doutoramento, ESAIQ-USP, 1972, mi meo. 
ção do "binômio soja-trigo", seja pelas especializações que oferece, (tratoristas, mecânicos, etc.) seja pelo contingente braçal que garante a oferta de trabalho nos momentos em que a le é necessárjo, sem conflitos com as demandas específicas do complexo agro-açucareiro pois seus calendários são complementa res.

Essa garantia, aliada a organização urbana prévia centrada em Tarumã, permite que a likeração da mão de obra em processiso, assuma um caráter agudo até a sua destruição. 
A integracão da micro-região homogênea de Assia no sisterna produtivo do "Complexo-Soja".

Como foi vịto anteriormente, o binômio soja -trigo tem suas origens no Rio Grande do Sul, onde a soja, de início representou um ganho adicional aos triticultores, seja pelo uso mais intensivo da terra, seja pela rotação maior do capital fixo, representaco tanto pelo uso mais intensivo de máquinas, equipamentos e instálações como pela melhoria da ter ra. o preparo para cultura mecanizada ${ }^{(1)}$, e/ou melhor utilização de resíluos do solo pela soja, em relação aos processos de erosão representaram portanto um(a) uso mais intensivo dos meios de produção, e (b) uma resposta significativa ao proces so de obsolescência programada de máquinas e equipamentos. $\Lambda$ lém de ganhos expressivos em termos de capitalização da atividade, teve um papel decisivo na consolidação econômica desse proces so produtivo.

Muito embora tanto em Santa Catarina como no $\mathrm{Pa}$ raná, e mesmo em São Paulo já existissem áreas triticultoras, somente após a consolidação do "binômio soja-trigo" como pro cesso de produção em rotação por sucessão, o processo foi ado tado de forma generalizada.

0 "peso" inicial do trigo na composição do binô mio já havia sido superado pela crescente importância econômi

(1) "destoca", curvas de nível, terraceamento, (combate à ero são de um modo geral). 
ca adquirida pela soja no mercado internacional, de forma que no processo de migração predominaram os parâmetros mais relacionados com a soja, aparecendo já o trigo como um "ganho adi cional". On dos aspectos importantes da inversão da importância desses dois produtos na formação do binônio se define peIa baixa ou nenhưna correlação de seus processos modernos, de adoção com as áress tradicionalmente produtoras de trigo,prin cipajmente, mas trmbéra de soja.

A soja, conhecicia em São Faulo a partir de 1908 atravéa dos imierantes japoneses, iminlantou-se comercialmente depois de 1950 atrevés de un trabalho sistenático de fomianto ligado à figura legenákicia de José Gomes da Silva, entẽo técnico do Instituto Agronômico de Campinz:s.

Sua importâncta econômice, entretanto foi inexpressiva, até que ela se implantou de forma "explosiva" em fins dos anos 1960, em áreas não tradicionais, como ocorreuna micro-região homogênea de Assis.

Essa região teve a área vizinha do Norte do Pa raná como efeito-demonstração e como base técnica e material da organizạção da produção do "binômio soja-trigo".

A adoção está liggada tanto ìs(a) bases naturais e sociais da produção existentes na região como $a(b)$ aspectos de conjuntura econômica, que agudizando a crise em certos setores produtivos regionais acabaram poi causar uma ruptura com os processos produtivos vigentes.

o papel da conjuntura como se verí, parece ter 
sido de tal grau de importância para a adoção do "binômio", que pegou de surpresa empresas processadoras de óleos comestí veis as quais estavam expandindo suas plantas industriais com a finalidade de extração de óleo de caroço de algodão e amendoim.

Tendo em vista que o processo agro-industrial normalmente toma decisões a partir de pesquisa de fontes abas tecedoras de mercado, pode-se admitir que nem mesmo elas, tra dicionais na região, tiveram conàições de prever essa trans formação o que as obrigou a reformular seus projetos e adap tar, às pressas, suas plantas para armazengmento e esmagainento da soja.

A éfoca da adoção do "binômio", a região de As sis apresentava, gxosso modo, os seguintes grupos produtivos:

a) setor Iigado a agro-industria de cana-de-açúcar, compreendendo rrandes propriedades a ministradas via "holding" e méaios produto res com contrato de formecinento de "quotas" por aafra, organizados de forma contígua sobre as terras "roxas" do sul, numa faixa qua se contínua entre Cândido Mota, Assis, Maracai e Paraguaçu Paulista;

b) setor ligado a agro-indústria alcooleira na região de Palmital, oritanizado em bases semeIhantes ao setor açucareiro;

c) pecuária de engorda, em propriedades médias 
E grandes; tanto instaladas em terras férteis do sul como em terrag "brancas" do Norte da resião;

d) médias propriedades policultorrs e/ou produ tos industriais, princtpalmente al-godão a amendoin e menos frequentemente produtoras de miltro e mandioce;

e) yequenas e mécias propriedaùes policultoras, procutores ae cercejs, (rilho), produtos industrizis (algodão, auendoim, mamona, café), suinos e gado bovino, principalmente para con sun:o doméstico.

f) embora sendo quase exceção na regiõo, pro priedades nonocultoras de café, ao norte (E(haporã, principalnente).

Muito embara a elta capacidade produtiva potencial des terres férteis do Sul (terras "roxas" do vale do Paranapanema), Ei organização produtiva desses grupos apresenta-se com beixos ándices de capitalizeção, à exceç̃̃o quase exclusiva da cara (açúcar e álcool).

En termos regionais, o estabelecimento pecuário invernista apresentava-se como o mais capitalizado, muito embora em padrões bem abaixo da média do centro-sul e a inter seç̧ão desse padrão de organização produtiva e de acumulação com conjunturas adversas à atividade pecuária jogou um papel decigivo no processo de adoção do binômio soja-trigo. 
Há que se levar em conta támbém o potencial pro dutivo do sul representado pela presença de terras férteis e adequadas à mecanização (suavemente onduladas).

Regiões mais importantes do ponto de vista da produção pecuária como as invermadas de Micro-Região Homogê nea de Presidente Prudente, muito mais capitalizadas, também sentiram a crise, mas embora apresentando alto índice de terras mecanizáveis, a não ocorrência de terras férteis, exten sivamente, atuou como um fator limitante na economicidade da adoção.

Dentro desse quadro podem ser distintos pelos menos dois monentos no processo de integração da área ao processo produtivo, representados pela (a) fase de adoção, quando o processo se instala nas terras ao mesmo tempo mais fér teis e nos estabelecimentos mais capitalizados de tamanhos com patíveis com os padróes fundiários exigidos pelo binômio (principalmente a propriedade pecuária do sul da região), e (b) a fase de expansão sobre as terras de fertilidade alta e média (terra "roxa" e terra "mista") sobre áreas de pequenas propriedades policultoras e áreas tomadas ao café, principalmente.

Há que se levar em conta tambén o papel das coo perativas de colonos italianos e alemães como fomentadoras da integração por suas ligações com congêneres do sul, demonstrạ do pela presença dos municípios onde essas cooperativas têm maior atuação ${ }^{(2)}$ como áreas precursoras no processo de adoção.

(2) Cruzália e Maracaí. 
Para compreender melhor a especificidade do pro cesso de integração da região ao processo produtivo do comple xo soja. será necessário fazer algumas observações, principalmente uma análise mais pormenorizada do desenvolvimento histó rico da divisão do trabalho na produção pecuária.

\subsection{A divisão do trabalho na produção pecuária regional}

Fm linhas gerais, 0 avanço historicamente mais evidente nos processos produtivos da pecuária brasileira estão ligados (a) à separação entre pecuária de corte e pecuária de leite com a introdução de raças adequadas à finalidade da pró dução, e (b) pelos processos diferenciados de manejo dos reba nhos e organização do estabelecimento pecuário.

Um avanço menos perceptível mas bastante signigicativo na diferenciação dos padrões de acumulação na pecuária de corte, por exemplo, é a introdução da divisão do trabą Iho na produção do boi entre as diversas categorias de estabe lecimentos pecuários especializados em fases do processo, sen do a mais frequente a separação entre cria, recria e engorda, que pode ocorrer sem incorporação de tecnologia e com um míni mo de incorporação de capital.

Esse tipo de divisão é tão mais importante na di ferenciação dos estabelecimentos e dos padrões de acumulação nas áreas menos importantes de produção pecuéria, como é o ca so da Micro-Região Homogênea de Assis, onde a organização da 
produção abriga todas as fases do processo.

A diferenciação no padrão de acumulação se dápe la transferência aos estabelecimentos de criaçäo, maior incorporação de trabalho pelas necessidades específicas de manejo, maiores investimentos em instalações e produtos farmacêuticos, e maior risco de perdas; pela transferência aos estabelecimentos de recria a rotação relativamente mais lenta do capital, (desde que o processo de transformação do bezerro após a desma ma até o boi adulto tem uma duração de cerca de 1,5 a 2 anos), deixando para o invernista a tarefa de formação de lotes de bois magros para a engorda (ciclo que se completa em menos de um ano em regime de pastejo com rotaçäo de campos, ocorrendo aí uma rotação mais veloz do capital)

É certo que o módulo fundírio exigido para a engorda é bem maior, limitando o acesso a essa fase do proces so, àqueles que de alguma maneira têm acesso aos recursos pa ra adquirir ou formar uma ou mais "invermadas" (3).

(3) Modernamente esse acesso é facilitado à população urbana não tradicional ao setor, com maiores facilidades de obtenção de crédito junto ao sistema financeiro, sendo o setor historicamente subsidiado e a produção encontrando alto preço no mercado; enbora manejada costumeiramente em baixo padrão técnico e incorporação de trabalho e em contrapartida alta rotatividade do capital investido, torma-se um setor altamente capitalizado, possibilitando re-in versões no processo de formação, ao mesmo tempo que remunera rapidamente o investimento. Isso explica a dominância no Oeste paulista de população tradicionalmente urbana na atividade pecuária, principalmente a presença de profis sionais liberais. Tradicionalmente, o processo de separação do criador, do invernista está ligado ao processo de separação do fazendeiro do sitiante, isto é, dos diversos mecanismos de posse de terra ligados principalmente às faixas de expansão do espaço produtivo (incluindo aí a "capacidade" de abrir glebas e assegurar sua posse, fazer frentealou agir com violência frente aos processos de grilagem, etc.). 
Um outro aspecto importante no avanço do proceg so produtivo é a diferenciação espacial entre zonas criatórias e as zonas de engorda.

Tradicionalmente, as criatórias se desenvolve ram em áreas distantes dos centros consumidores, em zonas de campos naturais, onde a extensividade da terra e seu baixo preço compensam um manejo menos técnico e as perdas.

As áreas de engorda foram se firmando a meio ca minho, entre os criatórios e os centros consumidores e se con solidaram tẽo logo foram regionalizados os processos de pro cessamento da carne através da instalação de centros de abate e frigorificação do produto.

Em todo esse processo de diferenciação, a região de Assis não se distingue nem pela qualidade de seu reba nho, nem pela capacidade de suporte de suas pastagens e muito menos portanto, pela sua definição como zona especializada em uma das fases do processo. Entretanto, pela existēncia tradicional da "fazenda" e do "sítio", a divisão de trabalho na produção ocorre intermamente, capitalizando mais o invernista.

A pequena propriedade policultora que possui al gum gado para consumo doméstico do leite é um formecedor per manente de bezerros para a recria e vacas para o abate. Os lo tes podem ser completados por aquisições fora da região, como por compras feitas a estabelecimentos onde a divisão de traba Iho no processo produtivo não se deu completamente (o que o corre nos municípios do norte da região, área de domínio da 
terra "branca", e do campo cerrado).

Un terceiro aspecto a ser ressaltado no processọ de diferenciação dos estabelecimentos e de sua capacidade de capitalização é a existência na região de um grande número de produtores sem terra, que pagam o acesso a ela promovendo a reforma das pastagens, pela rotação com culturas temporárias, principalmente algodão em contratos de parceria ou arrendamento.

O processo consiste em estabelecer um contrato de parceria com produtores sem terra os quais trabalham na ba se familiar e mais um ou dois "camaradas". O algodão ou milho é plantado sob regime de meação por dois anos, findos os quais a área deverá ser entregue com capim plantado, ocorrendo frequentemente a formulação de novo contrato para outra área de "pasto duro" o qual precisa ser reformado.

Esse processo de manutenção da capacidade de suporte ocorre sem dispêndios monetários para o proprietário e, em termos reais, contribui quase sempre com retormos em dinheiro ou produtos, resultante da meação; assegura uma contínua incorporação de trabalho e portanto de capitalização de suas terras. Tendo en vista que esse processo não é mediado pelo mercado ou o é fracamente ${ }^{(4)}$ ele se processa de forma contínua, sem "crises", tendo como único pressuposto a exis -

(4) dependendo das formas de contrato de parceria (com ou sem formecimento de equipamentos e insumos, etc...). 
tência, na região de trabalhadores sem terra.

Note-se que um efeito adicional desse processo é a manutenção da mão-de-obra cativa à propriedade terxitoxial, o que vem a ser rompido pela intrcdução da soja.

Outra carecterística importante dos estabelecimentos "invernistas" é a baixa reinversão de capital nos períodos de lucros altos. Os lucros são investidos em outros se tores, geralmente urbanos ou consumidos suntuariamente, mas o aspecto mais importante da reprodução do ciclo do capital no setor é a sua imobilização em mais terra. É esse o mais forte mecanismo de reprodução e depuração do invernista, pela atuação na reprodução do monopólio da terra em padrões de explora ç̃o bastante extensivos, independentemeate da capacidade poten cial de suporto em bases mais intensivas (5). Pela extensão do estabelecimento aliado ao grau de capitalização da terra pe los processos acima descritos, a propriedade pecuária teve um papel fundamental na integração do processo de adoção do"binô mio soja-trigo", como se verá.

\subsection{A adocão do binômio soja-trigo - as pré-condições.}

A adoção do "binômio soja-trigo" e a integração de produção no "complexo-soja" significou um certo grau de nup tura com os processos produtivos anteriormente adotados na re gião, expandinda-se seus efeitos para além dos estabelecimen-

(5) Fertilidade natural e situação. 
tos diretamente incorporados.

A incorporação da região ao processo produtivo do "complexo-soja" exigiu uma série de condições, muitas das quais existentes apenas de forma embrionária, que são: (a) ba ses naturais (condições ecológicas adequadas ao produto, fertilidade natural) adequadas à produção do binômio dentro dos padrões de produtividade média do Centro-Sul; (b) uma estrutú ra fundiéria e/ou formas de acesso à terra dentro dos padrõef

fundiários exigidos pelo processo; (c) a existênciade dis ponibilidade financeira (tanto ao nível de capital individual como de mercado) para investimentos na aquisição do "sistema de máquinas" vinculadas ao processo produtivo; a existênciace mão-de-obra especializada na manipulação do sistena de máquinas; (d) a existência de formecedores de insumos necessários e (e) a existência de capacidade de armazenamento e uma rede de comercialização do produto.

No que se refere às bases naturais, os solos féx teis de terra "roxa" e terra "mista" facilmente mecanicáveis pelå condições topográficas fávoráveis (terras levemente onduladas com declividades inferiores a $12 \%$ ocorrem extensivamen te no sul da região, numa faixa continua, a longo do rio Paranapanema (ver Fig. 2.2:,p.95).

Quento às condições ecológicas, a região possui aptidão climática e edáfica tanto para o trigo como para soja (ver Fig. 2.4 ).

As terras imediatamente disponíveis, tanto pe las condições naturais, como pela adequação aos módulos fun - 


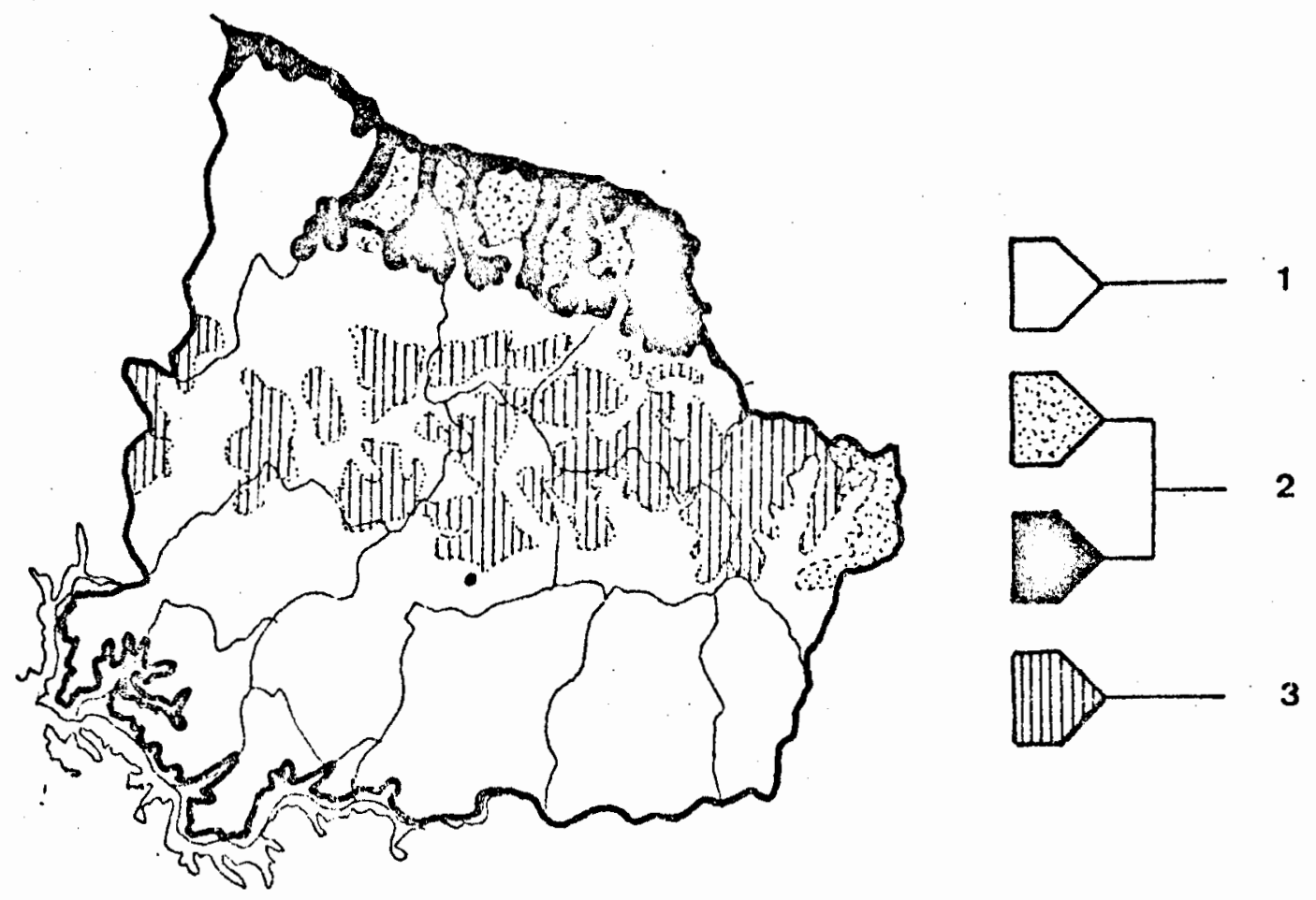

- classes de capacidade de oso jo solo(1)

\begin{tabular}{|c|c|c|c|}
\hline Ne & \$ de frea & Classe & Deserição \\
\hline I. & 60 & $I+I I-I I I$ & 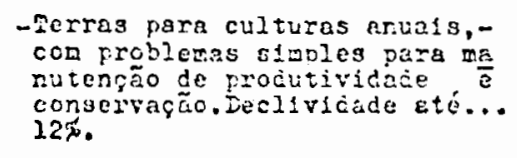 \\
\hline 2. & - 15 & $I V P-V I$ & 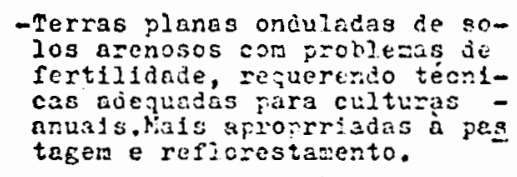 \\
\hline 3. & & . & $\begin{array}{l}\text { - Terras cem declives de } 20 \text { a } \\
\text { mais de } 40 \% \text { Indicadas para pas } \\
\text { tagem refiorestarento. Reque } \\
\text { rea práticas moderadas de con } \\
\text { servaräo. }\end{array}$ \\
\hline 3. & 25 & VIP & 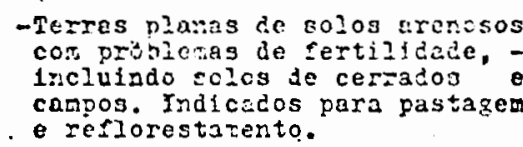 \\
\hline
\end{tabular}

Ponte: Zoneamento Asrícola do Estaco Ce Säo Paulo- Secretarle da Agricultira-Instituto Agronómico de Campinas, 1974. 
diários próprios do sistema produtivo era a "invernada" do sul da região que havia passado por todo o processo descrito de produção da terra, pela mecanização (destoca, combate à erosão, etc. ).

Por outro lado, esses estabelecimentos estavan capitalizados, a nível do capital individual, possuindo acesso tradicional ao sistema financeiro.

Eortanto fundamentalmente esse tipo de estabe lecimento que vai abrigar as primeiras experiências no proces so de adoção do binômio soja-trigo. Esses condições acime ar roladas, enbora fundamentais não são suficientes para ocasị nàr a substi.tuição no uso da terra. Enbora a integração do 政 raná tenha ocorrido a partir de 1965, existindo o "efeito-de monstração" e as bases técnicas de produção (insumcs, máqui nas, rede de comercialização) a substi tuição só ocorreu quando"configurou a jossibilidade de realização de lucros extraordinários (no cu:to prazo) em relação aos ganhos poseíveis na pecuária, quanio esta atravessava uma das piores crises, desde 1957, pela queda vertiginosa dos pre ços do boi em pé.

As condições concretas en que a adoção ocorreu se apresentou, como uma conjuntura de baixa nos preços reais do boi em pé,depois de alguns anos de recuperação e expansão que -eguiuà crige de 1964 .

Entre 1961-1964 o boi gordo sotreu uma queda nos preços em termos reais da ordem de $20 \%$ no período, sofrendo 
uma recuperação no período 1964-1966 da ordem de 112\%, supe rando pela primeira vez os preços reais de 1961.

Esse período caracterizou-se pela expansão da a tividade'pela incorporação de terras ao ramo produtivo.

Depois de 1966 verificou-se uma queda vertigino sa nos preços reais, atingindo $33 \%$ de perda em 1969 , em relação aos preços de 1966, afetando toda a pecuária e reduzindo a capacidade do setor en sustentar sua expansão física em pleno processo, de forma que pela primeira vez em muitos anos os pecuaristas tiveram que se descapitalizar para saldar sues dívidas: (como demonstra o Gráfico 2).

O ano de 1969 é um marco decisivo para os invernistas da região de Assis que passarain a ver na soja a possibi lidade de manter suas taxas de lucro.

Relativamente capitalizado, familiarizado com o sistema financeiro, ao qual recorre tradicionalmente, não viu dificuldades de fazer contratos de financiamento para o siste ma de máquinas que teve que adquirir integralmente, muito menos para financiar o custeio da produção dentro de um siste ma já consolidado da rede bancária, pela sua experiência em outras áreas.

Depois desse primeiro moinento, a recuperação econômica da pecuária de corte deixa de incentivar a substitui ção, mas já estavam criadas as bases para a consolidação econômica dó binômio pela via expansão em substituição a outras culturas. 


\section{GRÁFICO 2}

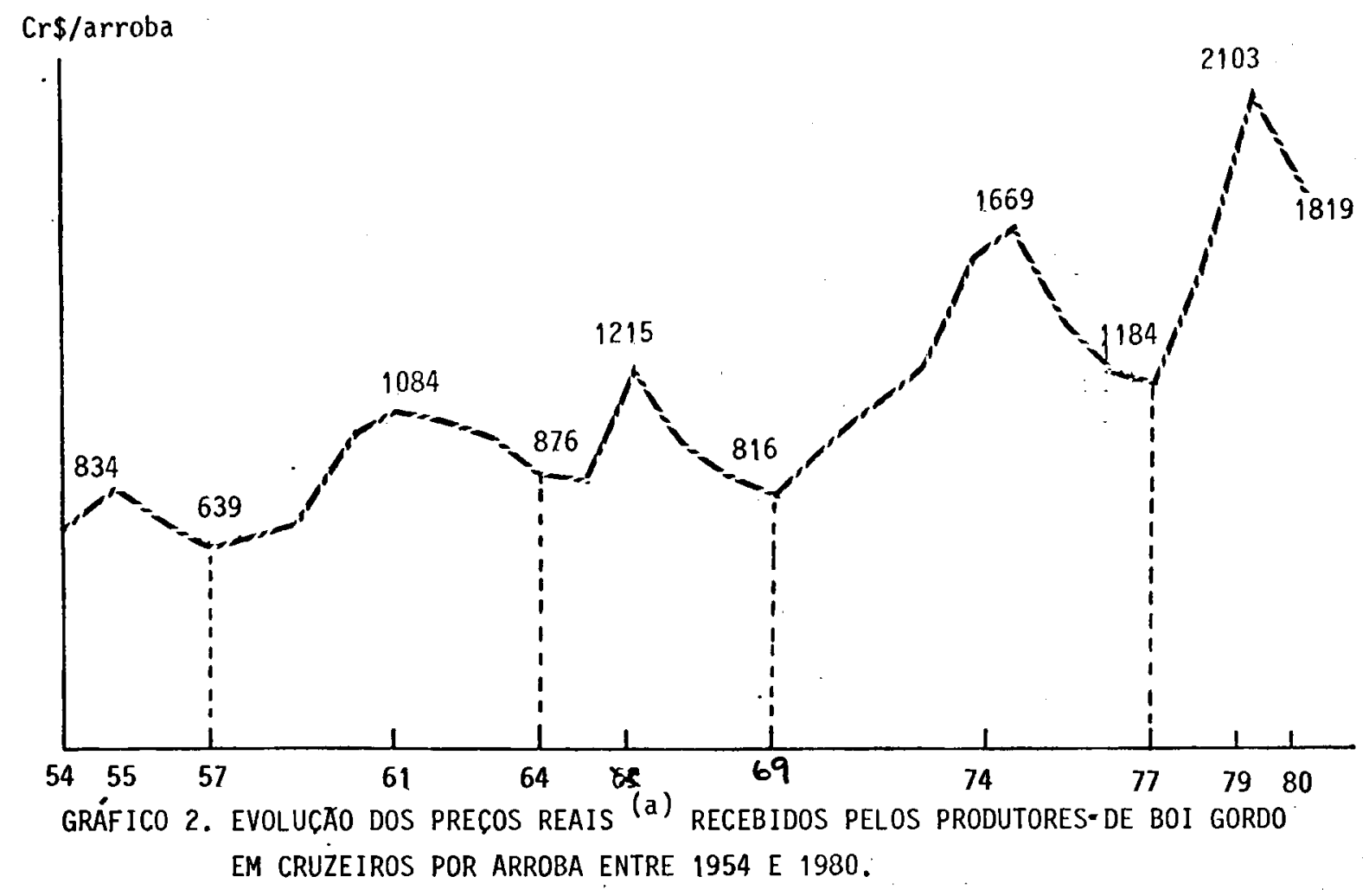

FONTE: Agroahalysis, 5(9):3-49, setembro/1981, p.31

(a) Deflacionado pelo IGP-Col. 2 -Conjuntura Econōmica, para dezembro de 1980 . 
Os efeitos da adoção da soja pelo estabelecimen to pecuário se expressaram pela existência e disponibilidade, na região, de (a) um "sistema de máquinas" com tempo ocioso, que poderia ser alugado por produtores menos capitalizados; (b) a instalação na região das bases do complexo produtivo(ex pansão da rede bancária, agências de máquinas e implementos, misturadoras de fertilizantes, expansão da capacidade de arme. zenagem e da rede de comercialização de grãos, expansão da capacidade regional de processamento de oleaginosas.

A recuperação econômica da pecuária de corte, não promove en grancie escala a reocupação das terras ảcixa das à soja. A manutenção do número de calveças de gado na re gião se dá por transformações no processo produtivo que permi tem a migração da pecuária para o norte (terras de campo cerrado), não competindo com o binômio no sulj e por um sensívelau mento da capacidade de suporte das pastagens que se deduz peIo leve aumento do número total de cabeças de bovinos (com uma diminuição de área total de pastagem)e pelo aumento das áreas de pastagens plantadas em relação às pastagens consideradas "naturais", como demonstra a Tabela 1.21 . 
TABELA 1.21 - PORCENTAGEM DO NÚMERO DE CABECAS DE BOVINOS EIU RELACÃO AO TOTAL MRH - ASSIS POR PERfO DOS SELECIONADOS.

\begin{tabular}{lccc} 
Município & $\begin{array}{c}1970^{(a)} \\
\%\end{array}$ & $\begin{array}{c}1975 \\
\%\end{array}$ & $\begin{array}{c}1980^{(\mathrm{b})} \\
\%\end{array}$ \\
\hline Assis & 12.4 & 9.7 & 10.2 \\
Borá & 2.7 & 3.0 & 3.3 \\
Campos Novos Pta. & 5.0 & 6.4 & 7.0 \\
Cândido Mota & 6.8 & 6.0 & 5.4 \\
Cruzália & 4.3 & 2.0 & 1.0 \\
Echaporã & 7.5 & 10.6 & 13.0 \\
Florinea & 2.9 & 2.5 & 2.3 \\
Ibirarema & 4.1 & 4.4 & 3.6 \\
Lutécia & 8.2 & 10.5 & 9.0 \\
Maracaŕ & 9.0 & 8.0 & 6.6 \\
Oscar Bressane & 5.3 & 5.2 & 5.1 \\
Palmital. & 6.0 & 4.5 & 4.4 \\
Paraguaçv : Paulista & 13.4 & 13.5 & 13.5 \\
Platina & 3.3 & 3.0 & 4.6 \\
Quata & 9.2 & 10.5 & 11.1 \\
\hline
\end{tabular}

FONTE: (a) Censo Agropecuário São Paulo - IBGE, 1970

(b) Censo Agropecuário de São Paulo - IBGE, 1975

(c) Sinopse Preliminar do Censo Agropecuário de São Paulo - IBGE, 1980.

A Figura 2.5 demonstra o processo de migração da atividade pecuária para as terras "brancas" do norte, destacando-se como municípios importantes Echaporã, Quatá, Cam - 


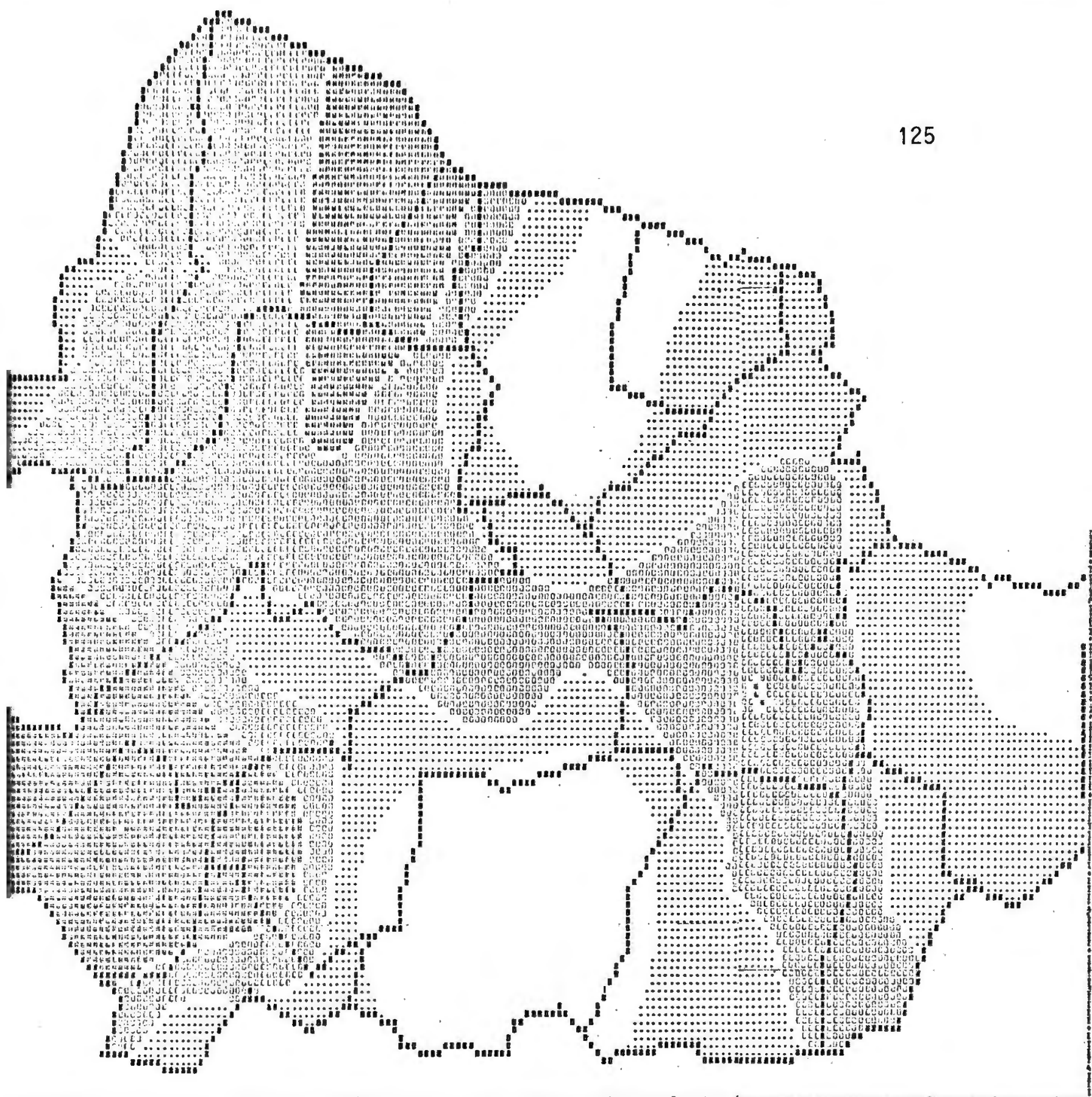

an+e+n+*

VRRIACAO CO NUALRD LE EAOECAS CE BOVINCS: 1975-197C

MAPA $\quad 2: 5$

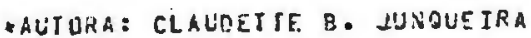

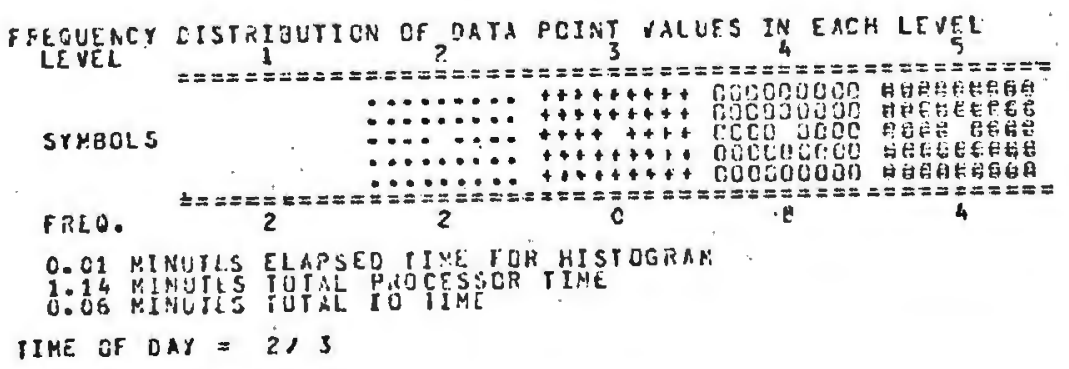


pos Novos e Borá.

Os municípios que demonstraram diminuição no nú mero de cabeças foram principalmente os municípios do sul(pre domínio de terras "roxas"): Cruzália, Maracaí, Assis, Palmi tal e Cândido Mota.

A variação da capacidade de suporte entre 1970 e 1975 representada pelo número de cabeças por hectare de pa.g togens pode ser verificada pela Tabela 1.22 a seguir.

A maior capacidade de suporte é verificada no conjunto dos municípios de Cruzália, Florínea, Cândido Mota e Ibirarema, todos ao sul da região, enguanto os maiores índi ces de expansão da capacidade de suporte entre 1970 e 1975 fo ram apresentados por Ibirarema, Cândico Mota, Florinea, Cruzália e Campos Novos Paulista, a exceção deste último, municí pios do sul da região(o que se explica pelas melhores terras, melhores "aguadas"), e a presença de Cantpos Novos é explicada pela expansão da própria região pecuária do norte do llunicí pio em direção ao aul onde ocorrem peguenas propriedades poli cultoras por serem essas terras "brancas" extrememente desvaIorizadas abrigando parte do contingente de pequenos produtores que vendeu, ou deu em arrendamento terras no sul, e tentou praticar a policultura ao norte da região.

Com o fracasso dessas tentativas muitos peque nos produtorea totalmente descapitalizados deixaram a região abandonando campos preparados para o plantio de pastagens, (o que pode ser feito sem muito investimento), pesando entretan - 
TAE:IIA 1.22 - NÚMERO TOTAL DE CABEÇAS DE GADO BOVINO E NUNERO DE CABEÇAS POR HECTARE NA MRH ASSIS ENTRE 1970 e 1975.

\begin{tabular}{|c|c|c|c|c|}
\hline & \multicolumn{2}{|c|}{1970} & \multicolumn{2}{|c|}{.1975} \\
\hline & $\overline{\mathrm{CABEC} \Lambda \mathrm{S}}$ & $\mathrm{CAB} / \mathrm{H} a$ & $\overline{C A B E C ̧ A S}$ & $\mathrm{CAB} / \mathrm{Ha}$ \\
\hline Assis & 41.634 & 0,89 & 30.875 & 1,07 \\
\hline Borá & 9.195 & 0,87 & 10.377 & 0,98 \\
\hline Campos Novos Pta。 & 34.797 & 0,42 & 24.665 & 0,89 \\
\hline Cândido Mota & 30.003 & 0,68 & 16.415 & 1,26 \\
\hline Cruzália & 13.043 & 0,96 & 4.585 & 1,45 \\
\hline Echaporã & 37.134 & 0,60 & 38.828 & 0,95 \\
\hline Florinea & 10.160 & 0,89 & 5.944 & 1,42 \\
\hline Ibirarema & 27.396 & 0,44 & 12.965 & 1,17 \\
\hline Irutécia & 31.170 & 0,78 & 34.958 & 1,03 \\
\hline Maracaí & 28.370 & 0,94 & 22.587 & 1,21 \\
\hline Oscar Bressane & 14.968 & 1,06 & 16.038 & 1,10 \\
\hline Palmital & 20.543 & 0,86 & 14.047 & 1,09 \\
\hline Paraguaç.u... Pta. & 71.730 & 0,56 & 56.408 & 0,82 \\
\hline Platina & 16.149 & 0,61 & 12.562 & 0,83 \\
\hline Quatá & 39.556 & 0,73 & 35.983 & 1,00 \\
\hline
\end{tabular}


to na melhoria da capacidade de suporte do município.

Uma outra classe de produtores que se incorpora ram mais cedo foram os produtores de algodão.

Essa cultura exa mecanizada ou moto-mecanizada, com tratores de baixa potência na fase de plantio. Os tratos culturais e a colheita eram feitos manualmente exigindo grande número de braços. A forma de contrato de trabalho mais comum era o sistema de parceria e arrendamento, ocorrendo a diversos proprietários manterem contrato com mais de uma famí lia para exploração de toda a extensão de suas terras.

Pouco antes da adoção doo binômio soja-trigo, as pequenas e médias propriedades de Cruzália, Florinea e sul de Maracaí dedicavam-se à cultura do algodão que vinha sofrendo frustrações de safra por problemas clináticos e preços baixos como comportamento estrutural do mercado.

Tendo como suporte a organização de cooperati vas em Cruzália (italianos) e Maracaí (alemães), a substitui ção deu-se de forma muito rápida, sendo necessário ressaltar - papel decisivo das cooperativas acelerando o pro cesso de integração, a liberação de um vasto contingente de mão-de-obra cativa trabalhando na produção do algodão e residindo na propriedade e que se transforma por esses processos em trabalhadores volantes (residindo nas periferias urbanas e viajando diariamente para a área de trabalho, como se verá mais adiante). 
No prosesso de incorporação ao binômio soja-. trigo podemos distinguir três grupos de municípios: (a) os precursores, (b) os municípios cuja expansão é lenta e (c) os tardios, que compõen a érea de expansão de modo significativo depois de 1975.

Os mumicípios precurscres ioram Cruzália e litara cai, os quais já upresentuvan en 1974, 95\% e 73\% do mérimo de área colhida no período 1974-1979. Eutre os municípios que compoem a área de expansão temos Cêndiỏo Mata, florinea e PaI mital, os quair e:n 1975 jé apresentevam 66\%, 67\% e 40\% do máximo da área colhida no mesto período e por fim 1 ssis e Paraguaçu Panulista, os quais após 1976 apresentum papel significativo na área colhida. Assis com 75\% em 1976 e Paraguaçu Pan lista com $68 \%$ em 1977, dentro dos mesmos critérios.

O Eráfico 3 mostra a presença dos diversos municípios produtores no processo de integração ao sistema so ja-trigo.

Se no processo de adoção, a grande propriedade pecuária e logo a seguir a média propriedade monocultora de algodão jogam um papel decisivo, no processo de expansão, a substituição se dá de forma mais complexa e a soja só não compete com a cana (açúcar e álcool), e o arroz.

Enquanto as oleaginosas e os cereais cedem $38 \%$ 
GRÄFICO NO 3

INDICES ACUMULADOS DE PRODUÇAO DA SOJA EM

MUNICIPIOS SELECIONADOS NA MRH-ASSIS $(1978-1979=1$ ）

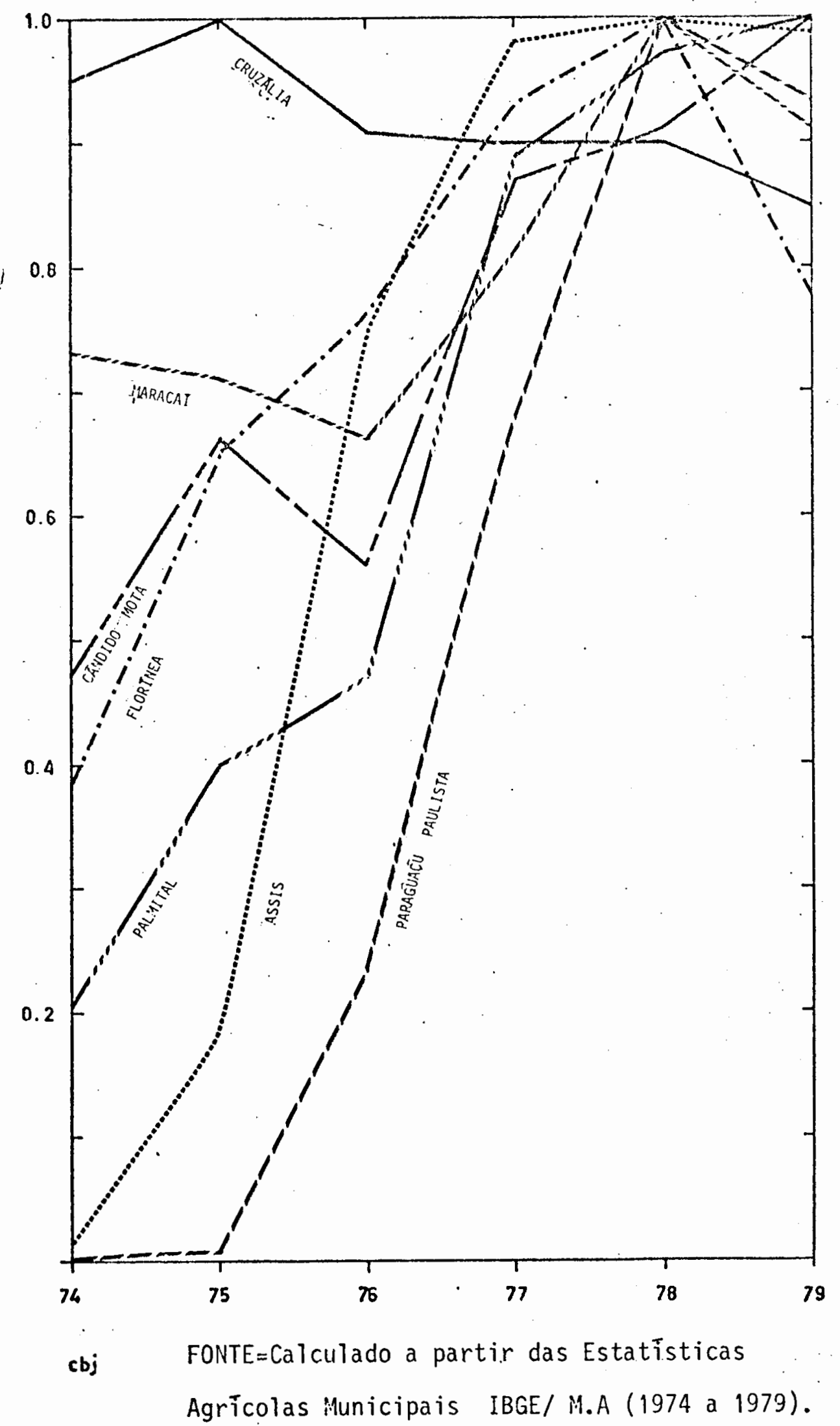


da área plantada entre 1970 e 1975 sendo mais significativo o algodão e o milho com perdas de $18 \%$ e $13 \%$ do total da área ce dida, as pestagens contribuem com $57 \%$ da área, sendo $30 \%$ em pastagens plantadas.

Isto significa que no período citado $68 \%$ da á rea cedida eram áreas cultivadas e $32 \%$ áreas que haviam sofri do menor trabalho (27\% de pastagens "naturais" ${ }^{(6)}$ e $5 \%$ de terras produtivas em descanso)。

Entre as atividades que sofreram expansão em área, as lavouras temporárias comparecem com um ganho de $91 \%$ da área cedida, comperecendo a soja com $71 \%$ dessa área e a cana de açúcar com 14\%, como pode ser observado na Tabela 1.23.

A expansão da área de lavouras temporárias foi bastante significativa, sendo o único tipo de utilização que sobrepujou o Estado em termos de comportamento como pode ser observado na Tabela a seguir.

(6) Segundo o Censo Agropecuário de 1970 e 1975 do IBGE são consideradas pastagens naturais, "ámeas destinadas 80 pastoreio do gado, sem terem sido formadas mediante plan tio, ainda que tenham recebido algum trabalho". XXIV = 1975. 
TABELA 1.23 SUBSTITUIÇÃO DE UTIIIZAÇTO DE ÁREAS NA ACROPECUÁRIA DA M R H - ASSTS ENTRE 1970 E 1975

1. Principais atividades que

cederan areas - Total

1.1 Lavouras - Total

44.200

.Algodã̃o........ 20.984

.Amendoim....... $\quad 5.557$

. Feijão......... 2.635

.Milho......... 15.024

1.2 Pastagens - Total

66.897

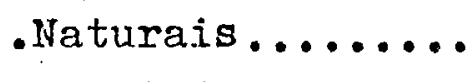

31.852

2. Principais atividades que

obtiveram ganho de area - Total

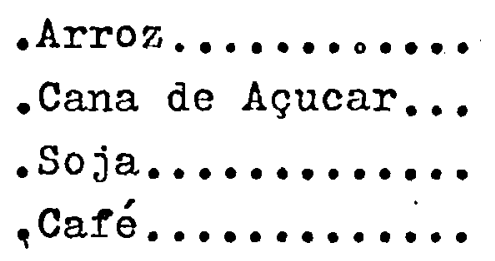

$$
7.364
$$

642 
TABELA 1.24 - UTILIZAÇÃO DAS TERRAS - PORCENTAGENS DE UTI IIZAÇÃO DA MRH-ASSIS EM RELAÇÃO AO ESTADO EN 2970 E 1975 。

UIILIZAÇ̃̃O

1970

1975

\% da Alrea total

3.1

3.1

IAVOURAs Permanontes

2.3

1.6

Temporárias

3.6

5.3

PASTAGENS Naturais

3.5

3.4

Plantadas

3.5

2.6

MATAS

Naturais

2.4

3.1

Plantadas

1.2

0.8

AREAS NÃO UTILIZADAS

2.1

2.1

FONTE: Censo Agropecuário de São Paulo - IBGE - 1970

Censo Agropecuário de São Paulo - IBGE - 1975

- o processo de expensão do "binômio soja-trigo".

No processo de expansão territorial do "binômio soja trigo" internamente à MRH-Assis foram incorporadas áreas significativas dos municípios de Assis e de Palmital enquanto os municípios precursores apresentam estabilidade de área ou mesmo declínio. 
O crescimento da área cclhida é geométrico até 1976, sendo o período 1975-1976 uma fase de transição para a região. Os processos de incorporação de terras por substituição de culturas tornam-se mais complexos pois até esse período já foram incorporadas cerca de $64 \%$ das terras em relaçäoao período 1978-1979.

Esse processo pode ser considerado tardio secom parado às demais áreas produtoras do Estado de São Paulo que, a nível agregado, já em 1974 apresentavam cerca de 70\% das ter ras incorporadas, tendo por base o período 1978-1979.

Esse diferencial de tempo joga um papel decisivo no comportamento das duas principais regiões produtoras tei do em vista que em 1975 eram iniciados grandes investimentos (máquinas e equipamentos) na MRH de Assis financiados pelosis tema bancário, tendo portanto os proautores contraído dívidas que os obrigava a dar continuidade aos empréstimos e endivida mento(e portanto à expansão de área), sendo o custeio iguajmen te financiado dentro de padrões técnicos rígidos, visando con solidar o processo produtivo, manter a produtividade e sobretudo o mercado de bens industriais, como se verá mais adiante.

Já os produtores da área da Mogiana, tendo ul trapassado em parte essa fase de implantação do processo, puderam ter um comportamento mais sensível. às variações de preços dos produtos e principalmente dos insumos, como pode ser observado no Gráfico 4 e Tabela $\dot{1}_{\text {.22 }}$. 
TABEIA 1.25 EXFANSTO DA SOJA - RREA CUITIVADA NO FERIODO DE 1970 a 1979

ESTADO DE SRO FAUIO - MRH - ASSIS E DDIAIS REGIOES

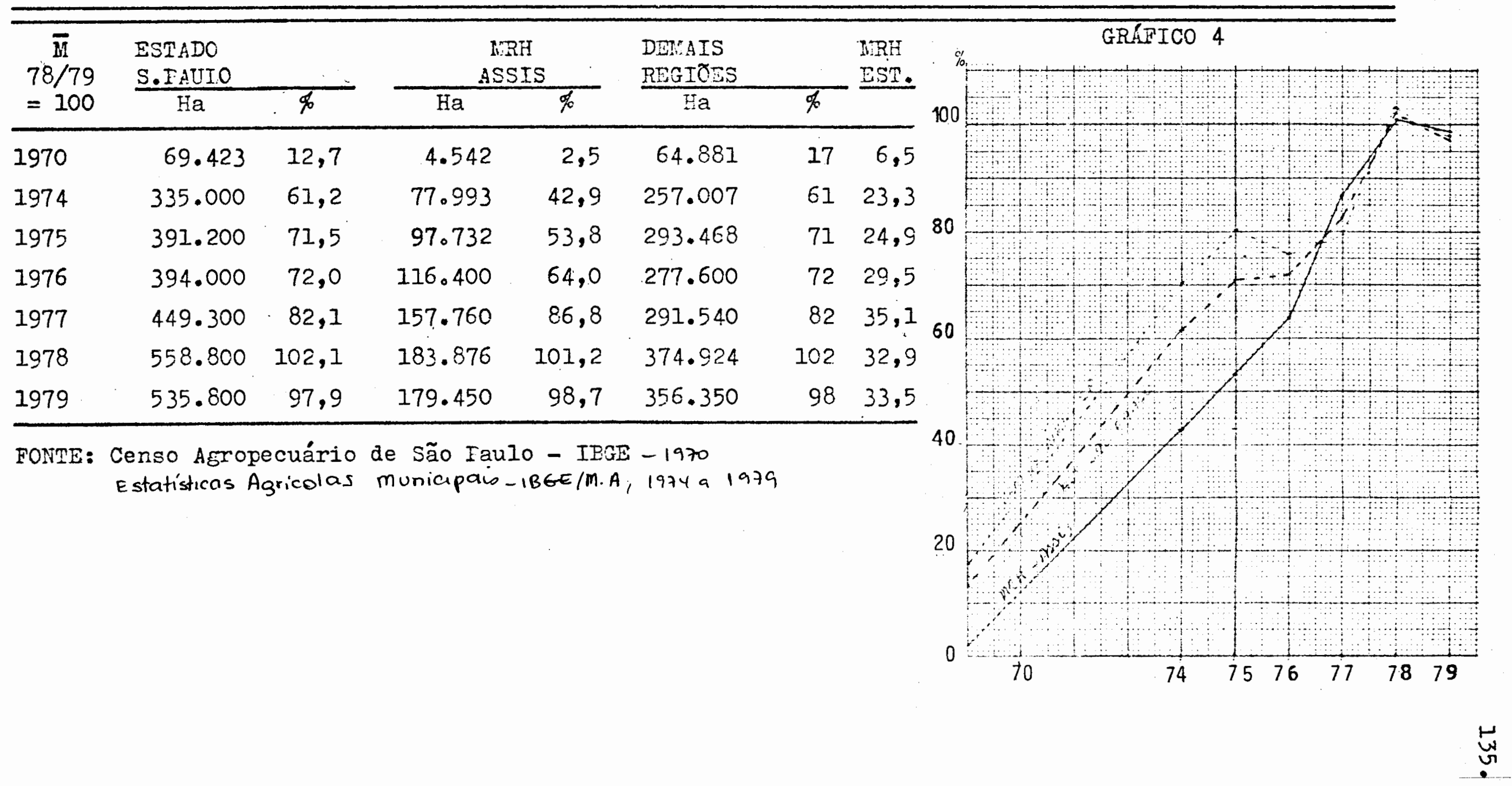


The

ESTADO DE SAO PAULO - MRH - ASSIS E DEMAIS REGIOES

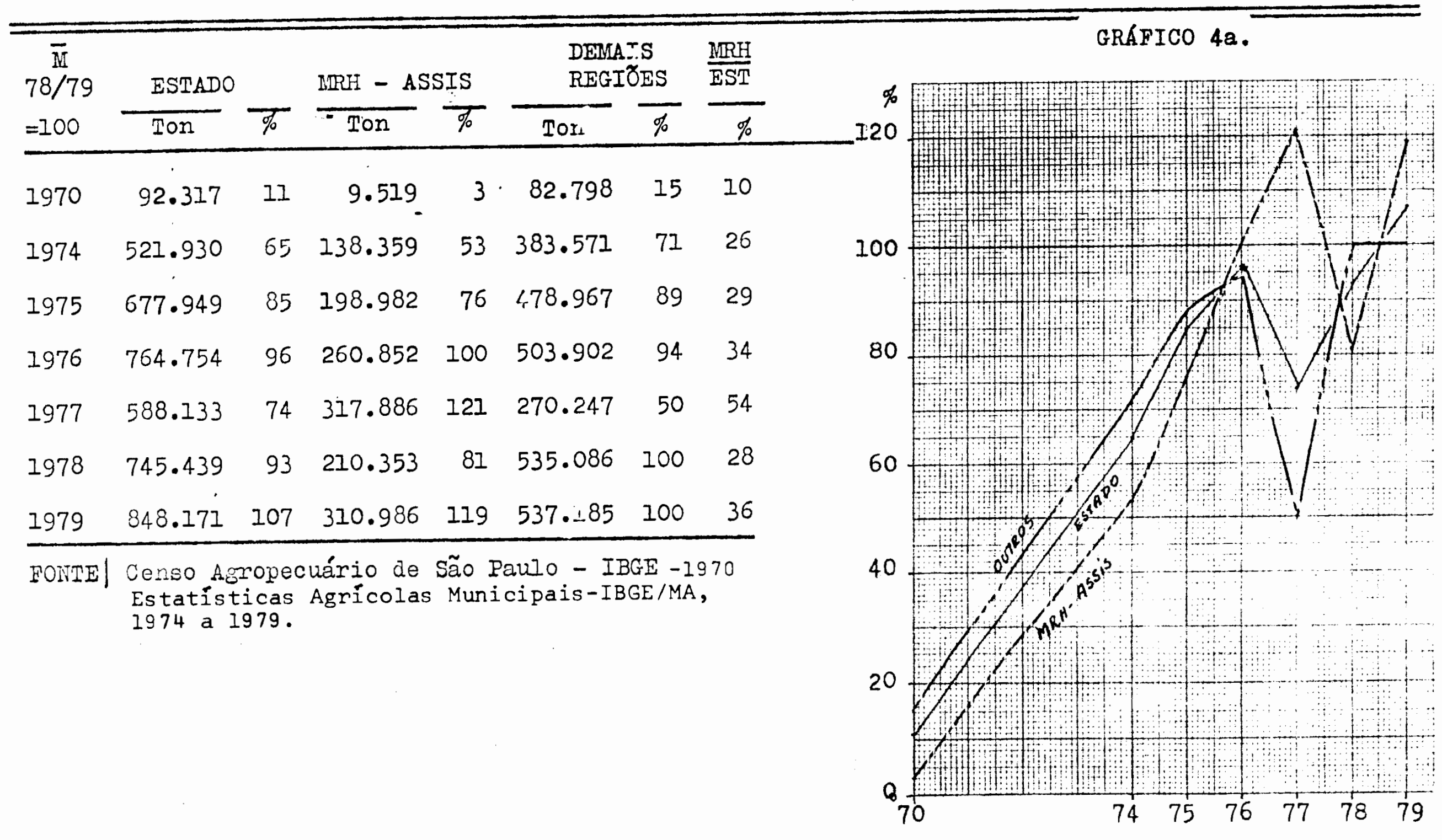




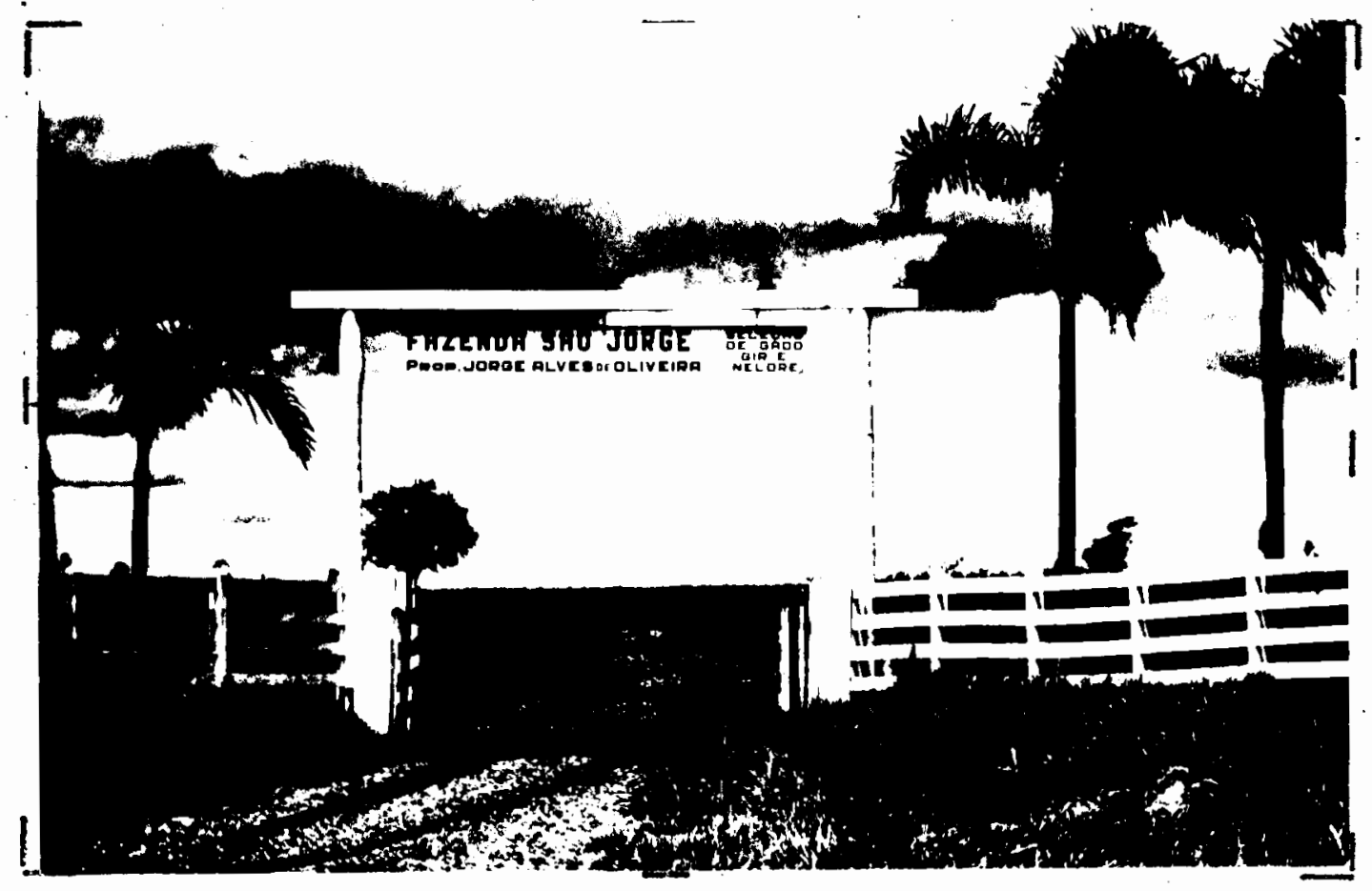

FCTO 1. A soja chega sobre as pastagens.

Estabelecimento pecuário ao sul de Assis

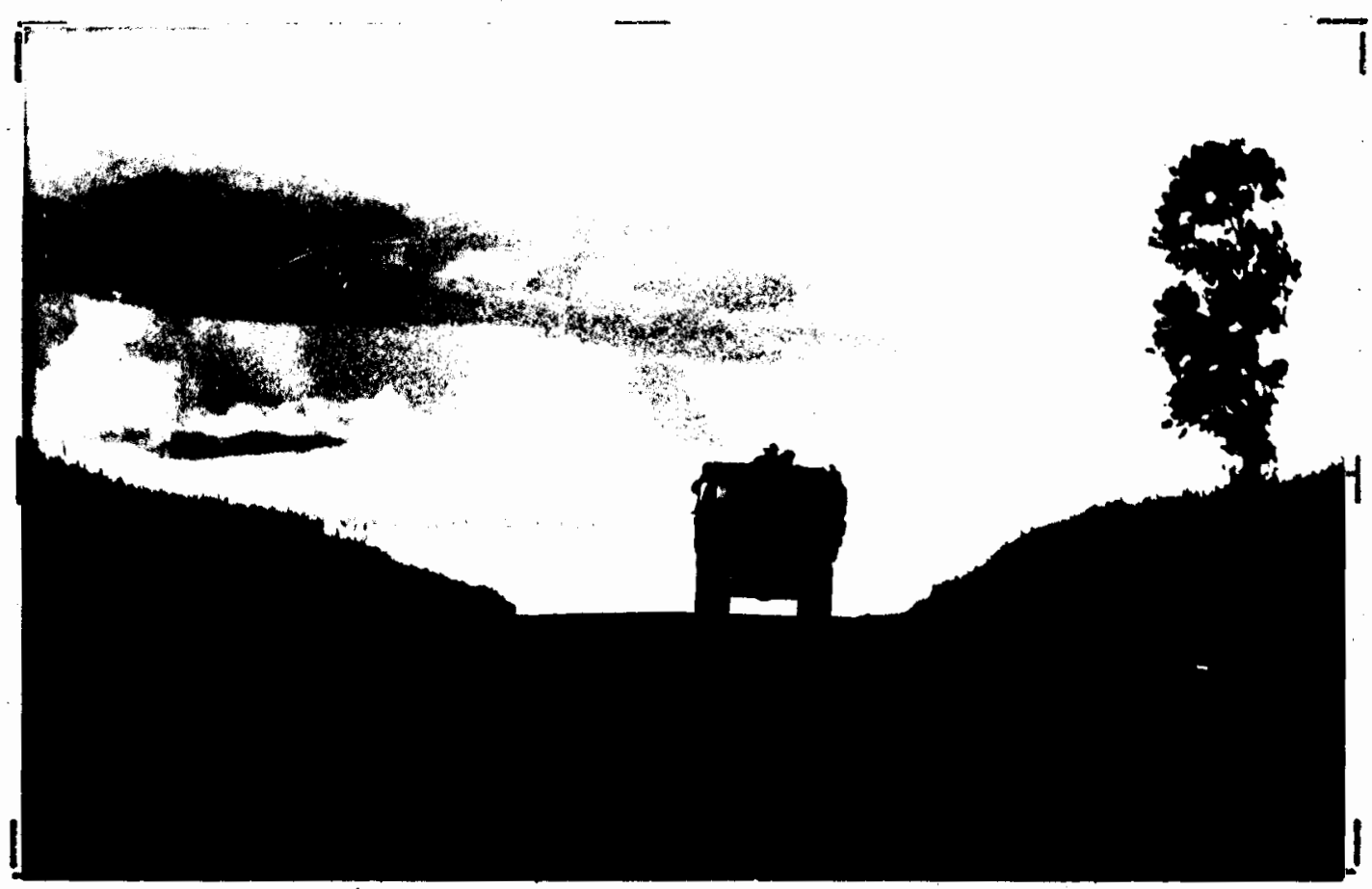

FoTO 2. Os trabalhadores saem...

Caminhão de turma na ST-333 
Enquanto a MRH-Assis, em termos agregados, irá reagir en termos de área plantada a partir de 1978, para o con junto do Estado essa reação está evidente a partir de 1975.

Numa análise do comportamento dos diversos muni cípios que compõem a MRH-Assis, nota-se que os municipio.s pre cursores demonstram mesmo restrição de área plantada, parecen do terem esgotado suas possibilidades de expansão, como é o ca so de Cruzália e Ilaracaí.

Por outro lado, as municiptos integrados tardia mente - após 1975 - como Assis e em menor grau Palmital, es tão ligadns ao processo de migração dos sojicultores, que ten do iniciado suas atividades nos municípios precursores com $\circ$ apoio de Cooperativas (italianos e alemães) puderam capitalizar-se, apesar das conjunturas desfavoráveis, e passaram a ad quirir propriedades em outros municípios, compondo estabeleci mentos de tamanhos mais compatíveis com os módulos fundiários exigidos pelo processo de produção.

Dessa forma deixaram suas propriedades em Cruzá lia e Haracaí(entre 12 e 30 hectares), sem vendê-las, e organizaram estabelecimentos de 100, 200 e até 400 hectares nas ter ras férteis dos Municípios de Palmital e Cândido Mota, adquirindo aos poucos os sítios à venda ecompletando a área economi camente explorável com arrendamentos de sítios vizinhos.

Essa migração deu-se de forma tão rápida que os preços da terra "de primeira" subiram em apenas seis meseg łe c\$ 50.000,00 para c\$150.000,00, no ano de 1977 . 
A concentração de terras nesses municípios foi muito rápida, causando quedas na produção pecuária e de cereais. (7)

A pecuária não só se afastou das grandes lavouras (cana e soja) pelo efeito de substituição como pelos efei tos nocivos dos processos produtivos das lavouras sobre as áreas de pecuéria, sobretudo nessas grandes lavouras onde inseticidas e herbicidas aplicados por aviões, ' acabam por espalhar veneno sobre as áreas de pecuária das pequenas propriedades vizinhas ocorrendo intoxicação e mesmo morte de animais.

Esse é um dos fatores que promove a desorganiza ção de pequeno estabelecimento policultor, obrigando as famílias a venderem suas propriedades e migrarem para outras áreas ou arrendarem suas propriedades para a expansão do plantio de soja e migrarem para a cidade, sendo transformadas por esse processo em pequenos rentistas agrários, como se verá.

Esses processos explicam em grande parte o cres cimento da área colhida em Cândido Mota, Palmital e Assis.Nes se caso a substituição de culturas é feita de forma mais complexa. Entre 1975 e 1979 foram incorporados cerca de 212.300 hectares, representando $40 \%$ da área de expansão a partir de

(7) Tendo em vista a proximidade da soja que abriga a "mosca branca" sem contudo ser muito atingida por ela, as la vouras de feijão entraramı em retração pois nessa lavoura o citado inseto é bastante destrutivo. 
1970. Desse montante apenas cerca de 25 mil hectares podem wr explicados pela substituição de milho, arroz, mandioca e café, não sendo possível estimar os montantes para a substituição de outros produtos exceto a cana de açúcar em Paraguaçu. Paulista.

do pequena ${ }^{(8)}$ ela foi decisiva para a incorporação das áreas de pequena propriedade, principalmente em Cândido Mota. Tendo sido praticamente destruídas as lavouras de café da região pe la geada de 18 de julho de 1975, ocorreu imediatamente a erra dicação dos mesmos e a preparação da terra para o plantio da soja (setembro a novembro).

Esse processo agudo teve significativa importân cia na liberação de mão de obra cative na pequena propriedade policultora na forma de parceiros e cclonos. Grandes contingen tes de trabalhadores sem terra se transferiram para as perife rias urbanas (Cândido Mota, Florinea e Tarumã) passando a tra balhar como volantes. O mesmo ocorreu com pequenos proprietá'rios cujo trabalho na pequena propriedade já não podia susten tar família numerosa, os quais passaram a vender o trabalho por dia, mesmo sem se desfazer da propriedade.

No processo de expansão mais do que no processo de adoção são melhor definidas as transformações quanto à pos se e uso da terra em termos agregados, muito embora, até 1975

(8) ceroa de 4.700 hectares foram liberados nos Municípios de Cândido Mota, Palmital e Oscar Bressane. 
140.

- processo de integração já estivesse consolidado em termos de "volumes" de tecnologia (quantidade e potência de trato res, colhedeiras, etc...o)。 
A trangformação ocorrida na composiç̃̃o dos meios de produção significou un aumento brutal de capital empregado na forma de máquinas, implementos e insumos agrícolas em geral, e uma ajjminuição também brutal do emprego e dos gastos com mão de obra.

Os fatores que influem no padrão técnico adotado são (a) o mercado a que se destina o produto - o mercado in .. ternacional, o que significa a necessidade de produzir a custos absolutos mundialmente coppetitivos - e (b) a ação do Es.. tado, pelo incentivo ao aumento da produtividade principalmen te dos produtos destinados à exportação. As formas incentivadas de produção exigem um alto grau de investimento em diver.. sos setores qúle atuam(c) na diminuição dos custos de produção * (b) no aumento da produtividade do trabalho, com as conse .. quências que serão exeminadas mais tarde.

A integração do frodutor ao "complexo soja" só sexá possível de forma duradoura na medià em que se adapte ao padrão técnico socialmente estabelecido, o que implice em (a) disponibilidades de recursos financeiros e (b) a contrapartida requerida pelas fontes de crédito, ou seja: remunera ção adequada do capital e um sistema de garantia aos emprés timos.

Se o sistema de máquinas define um padrão tećnico de produção mals ou menos homogéned a nivel do produtor, a sua integração a um sistema mais amplo, organizado em termos mundiaj.s requer uma reapropriação social do território, redefininào a divisão regional ( e internacional) do trabalho., criando um sistema de alimentação, controle e destinação da produção, que implica na produção de um esfaço adequado ao sistema. Trata-se de uma produção induzida externamente, tomando-se o espaço integrado a materialização do sistema, 
a nivel regional, com as características, conflitos e ten sões inerentes às transformações em curso。

Podem ser distintos entro doj.s hiveis de integra ção, para efeito de cuálise, ou seja (a) aqueje que se dá ao nivel imediato de produção e que imp]ica na reorganização da empresa rural (b) aquela que se expressa territorialmente num conjunto de elementos indispensáveis à reproducão do "complexo soja" a "jusante" e a "rontante" do produtor, ou se ja a integração da indústria de máquinas equipamentos e insumos, ao sistema crediticio de um lado, e o sistema de amnaze narnento, conercialização, industrializaçäo do grão incluindo ai adequaça äos meios de transporte e os terminais maritimos que agilizam a exportação.

Ocorre portanto a montagen de uma rede de sistemas de máquinas, que, caảa vez mais integralas, racionalizam todo o prosesso produtivo (a) rebaixando continuamente os cus tos pela incorporaşão de tecnologia mais avançada e (b) pro .. movendo a obsolescência contínua do sistera e a sua renovam ̧ão o que se traduz (c) numa crescente monopolização dos meios de produção, via monopólio técnico. (l)

0 aspecto de integração ao nivel do produtor re vela-se na análise da adoção do sistema de máquinas adequado à crganização da produção.

(1) Vejam-se as tentativas de aprovação das "leis das semen tes" no Brasil, para citar apenas un exemplo do processo de monopolizacão dos meios de produção. 
Consubstancia-se nas relações existentes entre as transformações na base téc nica e as mudanças concomitan te na organização social da produção, principalmente a ing tauração de una nova divisão técnica de produção. Dai desdo bram-se em um grande numero de consequências materializadas em um espaço reapropriado pela integração a um sistema produ tivo que se organiza em escala intejnacional. 


\subsection{O PROCESSO DE TRABATHO NO BIHÔMIO SOJA-TRIGO}

0 "binômio soja-trigo" é um sistema de cultivo em rotação por sucessão, istoé são plantados dojs produtos, um após o outro, obtendo-se duas safras em um mesno ano/safra.

Em suas origens, o"biriônio" era comandado pela produção do trigo, aparecendo a soja como produto complementar. Tendo em vista as condições de mercado favorável, o custo unitário mais baixo da soja brasileira em relação à soja americana, e - quase esgotamento da capacidade de expansão da produção americana, teve início em meados da década de 1960, um processo de "internalızação" do"complexo - soja", como foi descrito ante riormente.

Desde então a soja passa progressivamente a dominar o binômio, pois do papel de auxiliar na produtividade do trigo (in clusive por ser uma cultura melhorante), passa a comandar a economicidade da produção com os necessários ganhos de produti vidade, para competir mum mercado exigente.

Essa transformação se refllete em primeiro lugar na cornposição do calendário agrícola. Tendo em vista a alta sensibilidade da soja ao fotoperiodismo, sua produtividade irá depender do equilíbrio entre número de horas com luz e número de horas sem luz durante a fase de floração. Enquanto houver luz a soja estará em processo vegetativo, depois do que entrará em pro cesso de floração. 
Tendo em vista a necessidade de porte adequado da planta para colheita mecânica seu plantio não deve ser feito em geral antes de novembro, para que sejam atingidas as máximas produtividades. Para o binômio são indicadas variedades precoces que entram em (a) floração em prazo de 65 dias deven do coincidir o máximo possível com o solstício de verão (22 de dezembro), e (b) entram em maturação até março (período de co Incita) permitindo a preparação do solo para a semeação do trico.

Assim o calendário agrícola está condicionado às exigências das variedades de soja altamente produtivas da região. Esta vai ocupar o solo por cinco meses e meio, depois do que inicia-se o preparo do solo para o plantio do trifo, cujos limites de área, escolha de variedades e ciclo vegetativo condicionam a produtividade.

o calendário agrícola está composto entảo da seguinte forma:

\section{SOJA}

OPERACÃO

1.1. Preparo do solo

1.2. Plantio

1.3. Tratos culturais

1.4. Colheita
EPOCA

setembrc-outubro novembro dezembro- janeiro março

\section{TRIGO}

2.1. Preparo solo

2.2. Plantio

2.3. Tratos culturais

2.4. Colheita
março-al-riI

março-abril

abril a juzho

agosto-setembro 
O processo de trabalho do "binômio"permite a exploração econômica de módulos fundários A partir de 70 hectares, enquanto a exploração de soja como cultura única exige o patamar de 120 hectares.

Para uma análise detalhada do processo de trabalho fol tomada como exemplo uma propriedade do município de Maracal que pode ser considerada "típica", A exploração é efetuada pelo proprio proprietário, forma dominante na região

Será examinado o período de plantio de soja. A produtividade média alcançada em soja nos anos safra 1975/. 76 a $1977 / 78$ foi de 1700 gutlos por hectare:

Característica do estabelecimento en 1978 - área cultivada $=70$ hectares. 
2. SISTEMA DE MÁQUINAS

2.1. Máquinas e Equjpamentos

\begin{tabular}{|c|c|c|c|c|c|c|}
\hline $\begin{array}{l}\text { MAQUINAS } \\
\text { AUTONOTRIZES }\end{array}$ & MARCAS & $\begin{array}{c}\text { POTÂNCIA } \\
C: V .\end{array}$ & $\begin{array}{l}\text { PREÇO* } \\
\text { "O"KM }\end{array}$ & $\begin{array}{l}\text { VALOR* DA } \\
\text { IIAQUINA } \\
\text { USADA }\end{array}$ & $\begin{array}{c}\text { UTILIZAÇÃO } \\
\text { ANUAI }\end{array}$ & $\begin{array}{c}\text { UTIUIZAÇÃO } \mathrm{C} / \\
\text { SOJA }\end{array}$ \\
\hline TRATOR & IIF $65 \mathrm{X}$ & 57 & 180.000 & 90.000 & 520 & 320 \\
\hline TRATOR & CBT-1105 & 105 & 270.000 & $130000^{\circ}$ & 400 & 220 \\
\hline AUTOIOTRIZES & CLAYSSON & 105 & 540.000 & 300.000 & 150 & 80 \\
\hline & & $\overline{267}$ & $\overline{990.000}$ & $\overline{520.000}$ & $\overline{1.070}$ & $\overline{620}$ \\
\hline
\end{tabular}


2.2. INPIEMIENTOS

\begin{tabular}{|c|c|c|c|c|}
\hline IMPLEIIENTO & CARACTERISTICA & $\begin{array}{l}\text { IEIO DE } \\
\text { TRAGAOO }\end{array}$ & $\begin{array}{l}\text { FPECCO * NO } \\
\text { FORNECEDOR }\end{array}$ & $\begin{array}{l}\text { ANOS DE VIDA } \\
\text { UNIL -IEDIA }\end{array}$ \\
\hline ARADO & 4 DISCOS & TRATOR & 20.000 & 5 \\
\hline GRADE NIVELADORA & 42 DISCCS & TRATOR & 26.000 & 5 \\
\hline GRADE & 20 DISCOS & TRATOR & 35.000 & 5 \\
\hline SEREADEIRA/ADUBADEURA & 17 IINHAS & TRATOR & 45.000 & 5 \\
\hline DISTRIB. DE CALCAREO & $300 \mathrm{KG}$ & TRATOR & 15.000 & 5 \\
\hline CAFINADEIRA & 2 INXADAS & TRATOR & 7.000 & 5 \\
\hline PULVERIZADCR & 500 IITROS & TRATOR & 27.000 & 5 \\
\hline ATONIZADOR/POIVILHADOR & $60 \mathrm{KG}$ & TRATOR & 16.000 & 5 \\
\hline CARRETA & 2 TON. & TPATOP & 5.000 & 5 \\
\hline
\end{tabular}

(*) Freços de janeiro/1978. 
3. OPERACQESS

\begin{tabular}{lrrrr} 
& $\begin{array}{c}\text { HORAS } \\
\text { MAQUUMA }\end{array}$ & $\begin{array}{l}\text { DIAS } \\
\text { HOREM }\end{array}$ & $\begin{array}{l}\text { HORAS } \\
\text { DIA }\end{array}$ & SALARIOS \\
\hline 3.1 PREPARO DO SOLO & & & 10 & \\
- Aração & 120 & 2 & & 600 \\
- Gradeação & 220 & 2 & & 1100
\end{tabular}

3.2 PLAMTIO

16

- Semeadura

$30 \quad 5$

4.80

- Adubação

20

5

320

3.3 TRATOS CULTURAIS

- Capina. 30

30

8

- Aplic. Inseticida 90 11

2400

- Aplic. Herbicida 30

88 880 320

3.4 COLHEITA

- Corte

80

8

8

1000

7100

4. USO: DE IMISUR:OS

\begin{tabular}{|c|c|c|c|c|c|}
\hline & TII & MARCA & $\begin{array}{l}\text { QUANIII- } \\
\text { dADE }\end{array}$ & $\begin{array}{l}\text { PREÇO } \\
\text { UNI'T. }\end{array}$ & $\begin{array}{l}\text { PRIŞO } \\
\text { TOTAI, }\end{array}$ \\
\hline $4 \cdot 1$ & SEMTENTES & - & $7: 200$ & 7.50 & 54000 \\
\hline \multirow[t]{2}{*}{4.2} & ADUBOS & $4-30-10$ & 18000 & 4.50 & 81000 \\
\hline & . & $4-34--11$ & 18.000 & 4.60 & 82200 \\
\hline \multicolumn{6}{|c|}{ 4.3 DEIENSIVO } \\
\hline & \multirow[t]{2}{*}{ Inseticida } & Parathian & 1351 & 125,00 & 15000 \\
\hline & & Folimat 1000 & $45 \mathrm{I}$ & 280,00 & 12600 \\
\hline & \multirow[t]{4}{*}{ Herbleida } & Trifulalina & $120 \mathrm{~L}$ & 125,00 & 15000 \\
\hline & & Sencor & $440 \mathrm{Kg}$ & $1.000,00$ & 40000 \\
\hline & & Basagran & 120 & 300,00 & 36000 \\
\hline & & & & & 338950 \\
\hline
\end{tabular}

5. OUTROS ENCARGOS

Pessoal permanente $=2$ braçais 
A adoção do sistema de máquinas no "binômio"so ja-trigo" provocou uma reorganização na base técnica de produção, promovendo o(a) avanço da divisão do trabalıho, dentro e além da órbita imediata da produção através de (b) um processo ao mesmo tempo altamente substitutivo de mão de obra.

Ao nível da piodução imediata significou uma rup tura com os padrões anteriores, liberando a mão de obra cativa que passou a ser recrutada diariamente apenas para completar a "linha de produçäo" naqueles segmentos onde a aplicação de pro cessos mecânicos não fossem técnica ou economicamente viáveis.

A re-organização na base técnica da produção pro voca portanto uma reorganização no mercado de trabalho, com consequências (a) na formação de um exército de trabalnadores disponíveis competindo no mercado de trabalno $\mathrm{e}^{(\mathrm{b})}$ pelo consequente rebaixamento no nível de remuneração do trabalho e (c) uma alienação progressiva dos processos de produção do traba Ihador, que tende assim a perder o controle técnico da produ ção ( 9 ).

(9) "Isso é tanto mais certo tendo em vista que os aspectos técnicos dos processos de trabalho são agora dominados pe los aspectos sociais que o capitalista introduziu: isto e, as novas relações de produção... o processo de trabalho tornou-se responsabilidade do capitalista. Nesse problema de obter a "plena utilidade" da força de trajalho... torna-se exacerbado pelos interesses opostos daqueles para cu jos propósitos o processo de trabalno é executado e daque les que, por outro lado, o executam. $\mid .$. | para o capitalista, apresenta-se como o problema de gerencia"... cf. BRAVERMAN, H. Trabalho e Capital Monopolista, Zahar Ed. , 1977 , p. 59 . 
Analisando a evolução do número de volantes no Estado de São Paulo entre 1971 e 1975, GRAZIaNo e GASQUES ob servam que "o aumento relativo da mão de obra volante na população trabalhadora rural foi grande"... mostrando que "esse ala mento se deve mais à redução do número de trabalhadores resi dentes que propriamente ao aumento absoluto dos trabalhadores volantes" $(10)$.

Essa tendência se confirma parcialnente em relação à MRH-Assia porquanto o número de residentes sofre uma que da de 18,7\% entre 1970 e 1975, enquanto o. Estado apresenta uma queda de $13,8 \%$ no mesmo período. Ocorre ainda um aumento signi ficativo em termos de trabalhadores permenentes (91,0\% para o Estado e 90,1\% para a MRH-Assis). No Erupo de empregados tempo rários, enquanto o Estado apresenta um crescinento de $1,7 \%$, a MRH-Assis apresenta uma expansão de $145.5 \%$ apresentando um con tingente de 8.294 temporários, aproxinando-se em termos absol 즈 tos ao contingente de trabalhadores permanentes, com 8.623 tra balhadores, sendo o incremento agregado de permanenteglteuporá rios, superior aos incrementos negativos dos residentes e parceiros.

Esses dados indicam uma expansão absoluta na o ferta de trabalho em termos regionais, muito embore aumentodesa zonalidade para os volantes que conseguem trabalho "firme" ape

( 10) GRAZIANO DA SILVA, J. E GASQUES, J.G., - "Diagnóstico inicjal do volante em São Paulo" - in "Mão de Obra Volante na Agricultura, CNPa/UNESP/Polis, 1982, p.93-94. 
nas durante sete meses 80 ano. As variações nas categorias de trabalhadores para o Estado e para a MRH-Assis pode ser cong tatados na Tabela 1.26 abaixo:

TABELA 2.26 - PESSOAI OCUPADO NO ESTADO DE SÃO PAULO E NA MRH-ASSIS 1970 E 1975

\begin{tabular}{llll}
\hline \multirow{2}{*}{ TOTAL } & RESPONSAVEIS & PERMA- TENAPO- PARCEIROS \\
& POR FAMIUIA & NENTES RARIOS \\
\hline
\end{tabular}

1.ESTADO

\begin{tabular}{|c|c|c|c|c|c|}
\hline 1970 & 1.420 .040 & 873.243 & 288.308 & 181.964 & 65.928 \\
\hline 1975 & 1.346 .942 & 752.782 & 550.720 & 185.069 & 56.804 \\
\hline & -73.098 & -120.461 & +262.412 & +3.105 & -9.124 \\
\hline$\triangle{ }_{g e} \%$ & $5,14 \%$ & $-13,8 \%$ & $+91,01 \%$ & $+1,7 \%$ & $-13,83 \%$ \\
\hline
\end{tabular}

2. MRH-ASSIS

$\begin{array}{llllll}1970 & 36.602 & 28.119 & 4.535 & 3.378 & 329 \\ 1975 & 40.562 & 22.862 & 8.623 & 8.294 & 313 \\ \triangle & +3.960 & -5.257 & 4.088 & +4.916 & -16 \\ \triangle \% & & -18,7 \% & +90,14 \% & +145,5 \% & -4,9 \% \\ \triangle & & & & & \end{array}$

FONTE: Censos Agropecuários de São Paulo, IBGE, 1970,1975

Esses dados demonstram que embora em termos agregados 0 incremento de volantes seja pouco significativo, em termos regionais adquire um alto significado. Isto indica que embora a concentração da terra e a modernização da agricultura possa ocorrer de forma extensiva e explicar em 
parte essas · mudanças : as transformações nas relações de trabalho não ocorrem de Iorma extensiva mas de forma bastante concentrada, estando reservadas aquelas áreas do Estado que adotaram, na década de 1970 em diante, processos produti vos altamente substitutivos da mão de obra braça].

No processo de ruptura, a nível regional, ocor reu não apenas uma transformação radical nas relaçães de trą balho com a diminuição dos residentes sem terra como pelo au mento do absenteismo agrícole, fruto do processo de integra ção da produção.

Muito embora o trabalho se processe no campo, é a cidade o palco privilegiado das tensões e conflitos que ocorrem entre as diversas categorias envolvidas.

Enquanto para os trabalhadores a cidade tornouse o único "território livre", tendo en vista que a ocupação de terras, do Estado e particulares, é feita por produtores ex pandindo ern área a sua atividade, as necessidades de gerên cia de empresa agrícola deslocam necessariamente o produtor para o meio urbano, onde se define, pelo seu trabalho, o su cesso de sua empresa. Na cidade estão os bencos, os formece dores, a assistência técnica, os despachantes, os escritórios de comercialização, as empresas prestadoras de serviços, os "agiotas", os agenciadores da força de trabalho.

Enquanto para os trabalhadores a urbanização de veu-se às mudanças na base técnica de produção que pôde dispensá-los, para o produtor corresponder a uma contingência 
ligada à burocratização da atividade, consequência das inova ções surgidas na divisão social do trabalho.

Se por um lado, a divisẽo técnica do trabalho agrega às fases do processo, trabalhadores braçais sem nenhu ma especialização, por outro lado, agrega os especialistas : os condutores de máquinas, tratoristas, motoristas, aviado res agrícolas, mecânicos, técnicos agrícoles, agrimensores, engenheiros, agrônomos.

Essa mesma divisão técnica que estilhaça o pro cesso de trabalho em um grande número de segmentos, vai exd. gir a recessidade da gerência, isto é, de um grupo de pessoas que atuem no sentido de recompor a organicidade desse tra balho parcelado ou ainda, da manutenção do processo produtivo.

Se para ur grande número de produtores a fun ção de gerência é executada por eles rróprios, transformados de fuzendeiros em empresários, emerge um segmento social assalariado ou trabalhando por conta própria, especializado na composição de funções de gerência. São os recrutadores de mão de obra, os capatazes, os fiscais de produção, os contabilistas, os despachantes, etc...

Cresce assim o número de "especializações" urbanas em face da produção agrícola.

As implicações da divisão técnica do trabalho são de outra ordem.

"A divisão social do trabalho divide a socieda 
de entre ocupações, cada qual apropriada a certo ramo de pro dução; a divisão pormenorizada do trabalho destrói ocupações consideradas neste sentido, e torma o trabalhador inapto a acompanhar qualquer processo completo de produção" (II)

As consequências imediatas para os trabalhadores são (a) aumento relativo da reserva de mão-de-obra que a tua no rebaixamento dos salários, (b) a aproximação do custo de reprodução da força de trabalho aos padrões urbanos, sem contudo obter a mesma remuneração, degradando suas condições de vida e trabalho (c) a sazonalização do trabalho agrícola, obrigando os trabalhadores a circularem constantemente à procura de trabalho. A consequência imediata, mas não menos definidora (d) é a perda do controle técnico de produção.

O processo de urbanização e separação das condições objetivas de trabalho e do controle dos processos, a proxima esses segmentos da reserva de trabalho urbano da qual não se distingue, tendendo a desaparecer como categoria.

Enquanto essas condições não ocorrem entretanto, há uma degradação de vida e do trabalho desses contingen tes.

A unificação da regerva de trabalho, aproximan do o urbano do rural, não trouxe o benefício da remuneração urbana aos trabalhadores volantes. Cumprindo uma jornada e xaustiva de trabalho e na maior parte das vezes sem condi -

(II) BRAVERTAN, $\mathrm{H}_{\circ}$ op.cit., p. 72 。 
ções de obter meios diretos de hortas e pequenas plantações, por falta de espaço (de terra), esses trabalhadores viram a proximar-se os seus padrōes de reprodução aos padrões urba nos sem a contrapartida da paridade salarial, e sem as possi bilidades de formecimentio das "vendas" e armazéns que vendi am por mês e por "caderneta".

Esses estabelecimentos também atingidos pela "onda"de inovação foram sendo transformados em super-mercados Vendem à vista, como à vista é véndida a força de trabalho do volante. A monetarização da remuneração, entretanto, repre sentou uma perda do acesso a meios de vida diretos, ocorrentes nas relações tradicionais, no interior dos sítios e fa zendas, e portanto, a degradação das condições de vida dos trabalhadores porque nem sempre há trabalho e quando há, a remuneração flutua abaixo do salário mínimo urbano.

Uma das estratégias de sobrevivência encontrada pelas famílias de trabalhadores foi o engajamento de muTheres e crianças no trabalho braçal agrícola tendo por obje tivo aumentar a renda familiar.

Uma análise do engajamento das mulheres e dos menores de 14 anos nos trabalnos agxícolas demonstra um comportamento do Estado a nível agregado, antagônico ao comportamento da MRH-Assis. Enquanto decai o total do pessoal ocupado do Estado da ordem de 5\% entre 1970 e 1975 ocorre um acréscimo da ordem de $11 \%$ em termos regionais.

Comparando o grupo das mulherea, nota-se para 
- Estado um crescimento da ordem de $7 \%$ que demonstra o caráter geral do processo de engajamento feminino e que a nível regional cresce em $22 \%$ 。

Quanto ao engajamento de menores, enquanto o pe ríodo analisado acusa um decréscimo da ordem de $10 \%$ para 0 Estado, a reछião apresenta um incremento positivo da ordem de 53\%, como demonstra a Tabela 1.27 .

TABELA 1.27 NULHERES E MENORES DE 14 ANOS OCUPADOS ENTRE 1970 E 1975

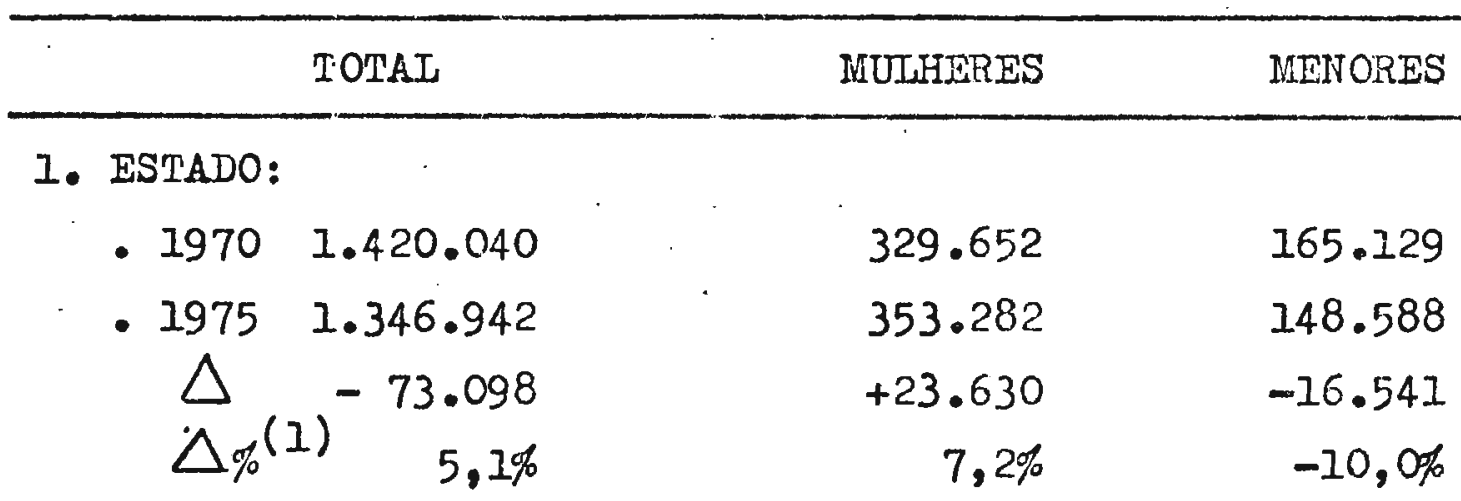

2. MRH-ASSIS

- $1970 \quad 36.602$

$\begin{array}{rr}7.236 & 3.687 \\ 8.851 & 5.645 \\ +1.615 & +1.958 \\ +22.3 \% & +53.1 \%\end{array}$

FONTE: Calculado do Censo Agropecuário de São Paulo, IBGE, 1970 e 1975

(I) base $=1970$ 
Uma análise por grupos de pessoal ocupado reve la uma transferência generalizada de nenores e mulheres do grupo de responsáveis e membros não remunerados para o grupo de empregados permanentes e para o grupo de temporários, is to é, para os gmupos remunerados. Reajmente os menores e mutheres recebem uma remuneração pelo trabalho, embora menor que a masculina. Entretanto o engajamento no trabalho não se deu recentemente como poderia se supor, pelo contrário, ocor re "a prática habitual do colonato, de considerar-se inclujda ao contrato como trabalhador (formalmente, individual) a mão-de-obra familiar [...] a relação essaluriada vigente no colonato só se torma viável porque a subsistência da família. trabalhadora é garantida de outra forma" ( 12 ). Esta outra forma é o plantio de mantimentos e a pequena criação para consumo direto ( $v$, tabelas $A 2$ a $A 5$, apendice 2 ).

Com a extinção do "colorato" e da parceria estão vigentes os padrões de exploração do trabalho que já se davam no seu limite.

( 12) BRANDT, V.C. op.cit. p.52 


\subsection{O Sistema de máquinas}

A Iigação da agricultura à indústria pola adoção de sistemas de máquinas a nível de propriedade, integradas a um processo produtivo crescentemente verticalizado significa, por um lado, (a) uma transferência contínua de atividades que antes eram agrícolas para o setor industrial. A indústria subordina a agricultura nos linites físicos e biológicos definidos pelo próprio grau de desenvolvimento das forças produ tivas, imprimindo a sua escala, seus ritmos e padrões de acumulação, (b) por outro lado transfere para a agricultura parte do processo produtivo que antes ocorria a nível industrial - em geral fora da órbita da emprêsa agrícola e do produtor direto, para o processo de produção imediato.

Dessa forma institui uma nova divisão de trabaIho entre setores o qual se caracteriza por um processo de "industrialização" da agricultura.

A adoção do sistema de máquinas instaura, necessariamente, uma nova divisão técnica do trabalho que se instala imediatamente ao nível imediato da produção e que repercute de diversas formas na organização social de produção.

A integração de MRH de Assis no "complexo-soja" define-se pela adoção das bases técnicas socialmente produzidas para a produção de soja e que se definem pela maior produ tividade do trabalho, através de (a) um aumento do número de máquinas e implementos, (b) pela expansão dos equipamentos mo 
torizados e diminuição dos instrumentos não motorizados e ani mais de tração, e (c) por um aumento contímuo da potência das máquinas a fim de atender as necessidades de rebaixamento con tínuo do preço destes unitários de produção.

Nesses processos produtivos altamente padronizados a máquina tem o principal papel na produção, entrando o homem como simples complemento dentro daqueles segmentos da linha de produção onde a "racionalização" ainda não foi tecni camente ou economicamente possível.

Existe portanto una alta correlação entre aumento no número de máquinas e potência de motores e a diminui ção do pessoal ocupado, ou melhor dizendo a sazonalização do trabalho agrícola, requerido para aquelas atividades que a in dústria não pôde oferecer ainda substitutivos.

Até 1978 a maior absorção da mão-de-obra braçal, recrutada entre "volantes', para a produção de soja era feita durante a fase de crescimento, entre dezembro e março, e consistia no trabalho de capina (duas ou três em todo o ciclo produtivo). Esse recrutamento era necessário apesar dos herbicidas empregados desde a semeadura pois tendo poder seletivo só eram eficientes os herbicidas aplicados às gramíneas de folha estreita; tornava-se assim mais compensador aplicar menos herbicida e contratar braçais para manter o campo de cultivo livre de pragas, requerimento indispensável à alta produtividade e`a colheita mecânica. 
Desde que forem sendo desenvolvidos herbicidas eficientes na eliminação das ervas daninhas, ocorrerá uma substituição do trabalho braçal (sazonal) pelo produto quí mico e pelos implementos que possibilitam sua aplicação (pulverizadores motorizados, aviões agricolas, etc.).

A expansão do capital fixo, imobilizado em máquinas e equipamentos pode ser avaliada pelo crescimento da potência instaląda na região que em termos agregados subiu de 91012 C.V. em 1970 para 269000 C.V. em 1975, apresentando um crescimento de quase $300 \%$.

Ura análise em nível de municiplo, entretanto, revela uma variação desses números percentuais. Há uma cla ra relação entre os maiores percentuais de aumento de potência instalada com os municipios maiores produtores de soja. As maiores contribuições ao incremento da potência Instalada são dadas por Cândido Mota e Palmital (16\%), Assis (13\%), Maracá (11\%), Cruaália e Florinea (9\%), Para guaçú Paulista $(8 \%)$, contribuindo esses municípioslóm incremento da ordem de $82 \%$ na capacidade instalada.

A aquisição de equipamentos e máquinas de maior potência e seu crescimento em número estão ligados à adoção do " biṇ̂mio soja-trigo". Aexceção do Municipio de Paragua cú Paulista, todos os municipios acima citados, apresentaram um decréscimo na potência instalada na classe de 100. V. a merios de $50 \mathrm{C} . \mathrm{V}$. tendo havido, em contrapartida um crescimento dos demais municípios, à exoeção de Lutecia, que acompanharam a tendência dos municípios sojicultores. 
O crescimento da potência instalada na classe de 10 C.v. e menos de $50 \mathrm{C.v}$. foi da ordem de $37 \%$ em termos agregados, sendo os outros $63 \%$ resultado da transferênciade $\underline{\underline{s}}$ ses equipamentos (e dos processos produtivos, em certa medida) para a periferia das áreas integradas, como pode ser observado na Tabela 1.28 .

O processo de substituição de implementos de tração animal por implementos motomecanizados foi rápida e extensiva, porquanto um efeito do processo de transferência de equipamentọs de menor potência para a periferia da área fulcro de produção do "binômio soja-trigo". A excęão de Campos Novos Paulista e Paraguaçu Paulista, todos os demais muni cípios apresentaram quedas no número de arados de tração ani mal e transformações nos processos produtivos tradicionais, como reflexo das transformações na área fulcro, como adiante se verá.

Ocorre também uma acumulação de meios de produção desde que a diminuição do número de arados por tração ani mal entre 1970 e 1975 é da ordem de $27 \%$ e o aumento do número de arados por tração mecânica é da ordem de $133 \%$ entre 1970 e 1975.

Enquanto a área ocupada com soja cresce 19 : vezes entre 1970 e 1975, o número de proprietários de monomotrị zes e colhedeiras cresce 1,8 e 1,3 vezes, respectivamente.

A evolução dos preços dos tratores apresentou-se decrescente em termos reais desde 1968 até 1975. 0 decréscimo nos preços se configura como um grande responsável pelo crescimento da demanda de tratores, face à melhoria da 
TABELA 1.28 TRATORES - MAQUINAS E INSTRI'MENTOS AGRICOLAS

M R H - ASSIS NO ANOS DE 1970-1975-1980

\begin{tabular}{|c|c|c|c|c|c|c|c|c|c|c|c|c|c|c|c|}
\hline $\begin{array}{l}\text { MUNICIPIOS DA } \\
\text { MRH - ASSIS }\end{array}$ & & TOTAL & & & $\bar{e} 10$ & $\begin{array}{l}\text { LES } \\
\mathrm{CV} \\
\end{array}$ & $\begin{array}{l}0 \text { MU MU } \\
\text { ciass } \\
10\end{array}$ & $\begin{array}{l}\text { NICIF } \\
\text { es } \\
+50 \\
\end{array}$ & $\begin{array}{l}10 \\
\mathrm{He} \\
\mathrm{CV}\end{array}$ & $\begin{array}{r}E C L \\
\text { Pote } \\
\quad 5 \\
\end{array}$ & $\begin{array}{l}\text { SSE D } \\
\text { Cia } \\
+100\end{array}$ & $\mathrm{CV}$ & $\begin{array}{r}\text { NCIA } \\
100 \\
\end{array}$ & CV & nais \\
\hline & $\overline{70}$ & 75 & 80 & 70 & 75 & 80 & 70 & 75 & 80 & 70 & 75 & 80 & 70 & 75 & 80 \\
\hline 1. Assis. & 226 & 472 & $\overline{534}$ & 5 & 5 & - & $\longdiv { 1 1 2 }$ & 86 & - & $\overline{107}$ & 323 & - & 2 & 57 & - \\
\hline 2. Borā & 18 & 37 & 75 & - & - & - & 6 & 10 & - & 12 & 25 & - & - & 2 & - \\
\hline 3. Campos Novos Pta. & 48 & 155 & 172 & 4 & 3 & - & 31 & 56 & - & 13 & 84 & - & - & 12 & - \\
\hline 4. Candido Mota & 183 & 522 & 600 & $1 . c$ & 4 & - & 114 & 112 & - & 53 & 369 & - & 4 & 37 & - \\
\hline 5. Cruzālia & 319 & 464 & 397 & 1 & 1 & - & 209 & 52 & -1 & 08 & 374 & - & 1 & -7 & - \\
\hline 6. Echaporã & 48 & 110 & 149 & 3 & 3 & - & 26 & 39 & - & 18 & 62 & - & 1 & 5 & - \\
\hline 7. Florinea & 126 & 278 & 217 & 6 & - & - & 32 & 14 & - & 64 & 190 & - & 24 & 74 & - \\
\hline 8. Ib irarema & 42 & 115 & 189 & - & - & - & 27 & 53 & - & 15 & 56 & - & - & 6 & - \\
\hline 9. Lutecia & 89 & 122 & 170 & - & 2 & - & 49 & 42 & - & 32 & 62 & - & 8 & 16 & - \\
\hline 10. Maracai & 304 & 449 & 616 & 21 & 3 & - & 239 & 116 & - & 42 & 298 & - & 2 & 32 & - \\
\hline 11. Oscar Bressane & 71 & 90. & 104 & - & 1 & - & 41 & 19 & - & 29 & 70 & - & 1 & - & - \\
\hline 12. Palmital & 171 & 466 & $6 \cdot 2$ & 6 & - & - & 114 & 58 & - & 50 & 345 & - & 1 & 63 & - \\
\hline 13. - Braguaguca Pta. & 161 & 381 & 540 & 2 & 5 & - & 25 & 138 & - & $7 !$ & 219 & - & 3 & 19 & - \\
\hline 14. Platina & 53 & 87 & $1 ? 5$ & - & 2 & $=$ & 24 & 10 & - & 27 & 55 & - & 2 & 20 & - \\
\hline 15. Quatā & 68 & 215 & $2 y 8$ & 1 & 8 & - & 39 & 68 & + & 28 & 135 & - & - & 4 & - \\
\hline
\end{tabular}

FONTE: Censo rgropecuário de São Paulo- IBGE, 1970,1975.

Sinópso do Censo Agropecuário de São Paulo-IBGE, 1980. 
TABELA - 1-29EVOLUCAO DO PRECO DE TRATORES NO ESTADO DE SAO PAULO ENTRE 1969 e 1980 (a) E UNIDADES DE SOJA NECESSARIAS PARA ADQUIRIR UM TRATOR LEVE ( 44 C.V. )

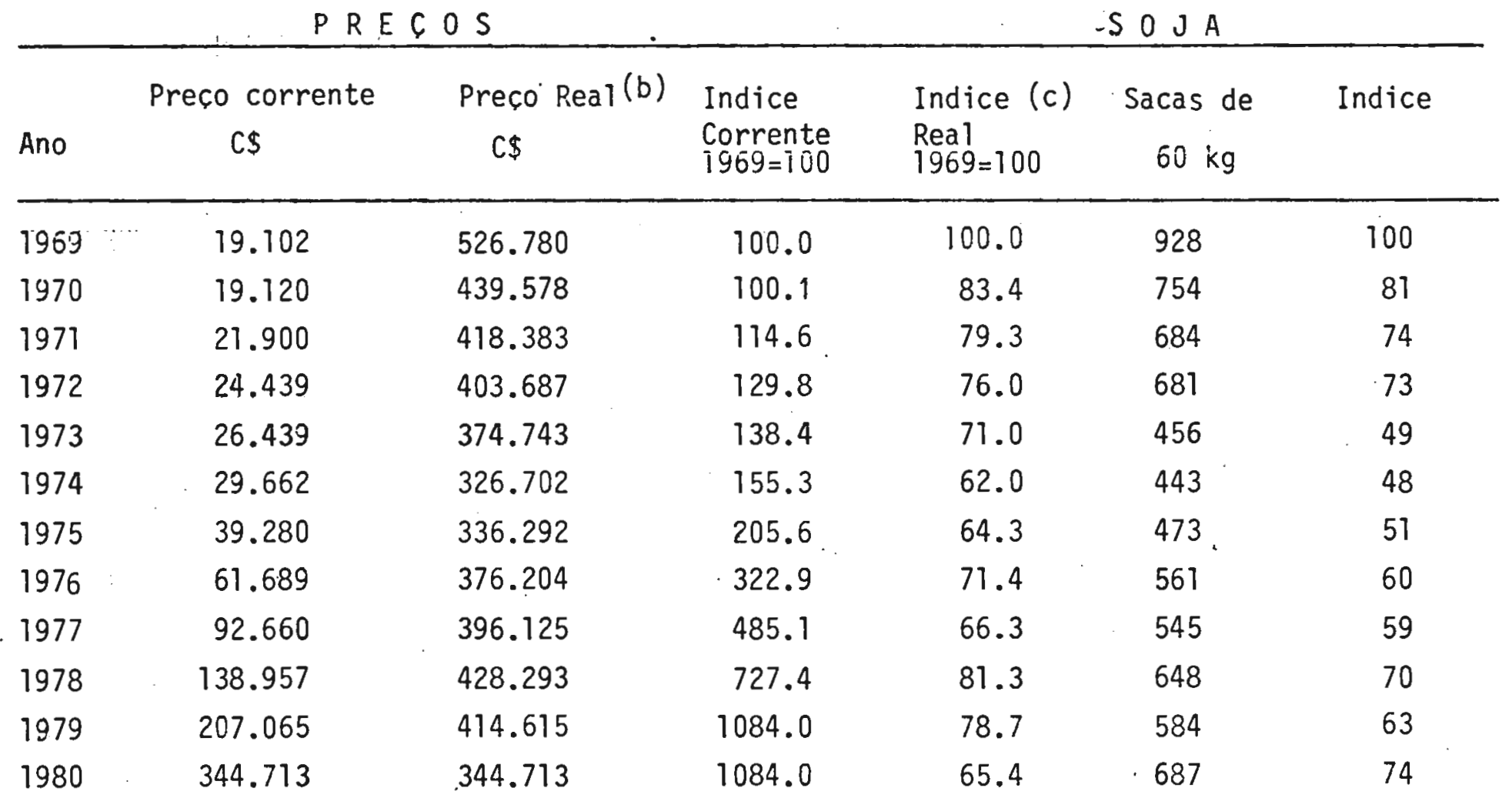

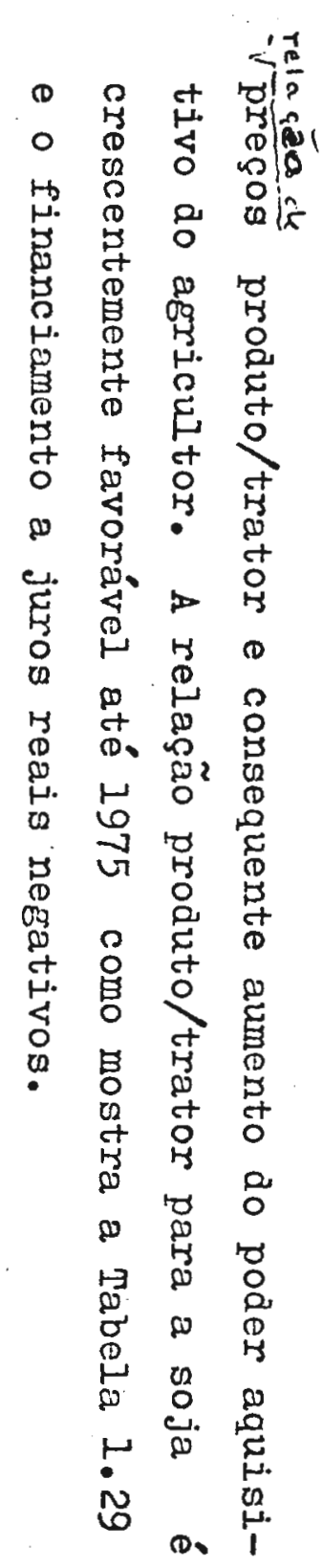


Quanto ao número de proprietarios, tcorre realmen te um processo de concentração de meios de produção. No que diz respeito às colhedeiras, deve ser levado em conta o proces so de substituição por equipamentos de maior capacidade produtiva e maior potência, durante o período da observação.

Os municípios maiores produtores de soja form responsáveis por mais de $80 \%$ da substituição de arados por trą ção animal.

Esses mesmos municípios apresentam percentacem de motorização da tração variando entre $78 \%$ a quase $100 \%$ à exceção de Faraguaçu Faulista, como pode ser observado nas Tabelas 1.30 e 1.31.

For outro lado há uma forte distinção entre municípios, pelo dominio da tração animal. Os municípios do norte da região: Bora, Echaporã, Iutécia, Oscar Bressane, Ilatina, : Quatá e Taraguaçu Faulista apresentam 51,3\% dos equipamentos de tração animal da região, mas apenas $19 \%$ da tração motorizada e $23 \%$ da potêrcia instalada. Desse conjunto, o minicípio que apresenta maior diversificação é o município de Taraguaçu Faulista, cuja parte sul com presença de terra "roxa" acha-se integrado ao "complexo - soja", apresentando ainda vastas áreas de cana-de-açucar para fornecimento às usinas de quatá (até 1978), com áreas de pastagens muito pobres sobre campo cerrado. 
TIBEIA 1.30 USO E FORGA UTIIIZADA TOS TRABATHOS AGRRRIOS KA YRH - ASSIS TO ANO DE 1975

\begin{tabular}{|c|c|c|c|c|c|c|c|}
\hline \multirow{4}{*}{$\begin{array}{l}\text { MONICLPIOS DA } \\
\text { MRH - ASSIS }\end{array}$} & \multicolumn{3}{|c|}{ 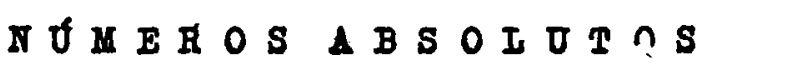 } & \multicolumn{4}{|c|}{ N $M E R O S R E I A I I V O S$} \\
\hline & \multirow{3}{*}{$\begin{array}{l}\text { TOTAL DE } \\
\text { INFORMANTES }\end{array}$} & \multicolumn{2}{|c|}{ TIPO DE TRACTO } & \multicolumn{4}{|c|}{ TIPO DE TRACYO } \\
\hline & & & & \multicolumn{2}{|c|}{ \% DA MRH } & \multicolumn{2}{|c|}{ \% DO NUNICAPIO } \\
\hline & & ANDMAI & MOTORIZ ADA & ANTMAI & MOTORIZADA & ANIMAI & MOTORIZADA \\
\hline 1. ASSIS & 768 & 281 & 599 & 7,5 & 21,9 & 36,6 & 80,0 \\
\hline 2. BORS & 70 & 63 & 15 & 1,7 & 0,3 & 90,0 & 21,4 \\
\hline 3. CAMPOS NOVOS PAULISTA & 443 & 194 & 334 & 5,2 & 6,7 & 43,8 & 75,4 \\
\hline 4. CANDIDO MOTA & 1.092 & 438 & 857 & 17,6 & 17,2 & 40,1 & 78,5 \\
\hline 5. CRUZAIIA & 352 & 7 & 350 & 0,2 & 7,0 & 2,0 & 99,4 \\
\hline 6. ECHLAPORX & 256 & 212 & 84 & 5,6 & 1,7 & 82,8 & 32,8 \\
\hline 7. FLORINEA & 231 & $\cdot 47$ & 188 & 1,2 & 3,7 & 20,3 & 81,4 \\
\hline 8. IBIRAREMA & $32 ?$ & 45 & 302 & 1,2 & 6,0 & 14,0 & 93,8 \\
\hline 9. IUTECIA & 286 & 230 & 93 & $6,1=$ & 1,9 & 80,4 & 32,5 \\
\hline 10. MARACAI & 568 & 159 & 464. & 4,2 & 9,2 & 30,7 & 89,6 \\
\hline 11. OSCAR BRESSANE & 316 & 266 & 84 & 7,0 & 1,7 & 84,2 & 26,6 \\
\hline 12. PAIMITAL & 1.243 & 660 & 978 & 27,5 & 19,5 & 53,1 & 78,7 \\
\hline 13. PARAGUA ̣UI PAULISTA & 753 & 529 & 443 & 14,1 & 8,8 & 70,3 & 58,8 \\
\hline 14. PLATINA & 193 & 155 & 124 & 4,1 & 2,5 & 80,3 & 64,2 \\
\hline 25: QUATA & 541 & 478 & 107 & 12,7 & 2,1 & 88,4 & 19,8 \\
\hline TOTAL MRH & 7.434 & 3.764 & 5.022 & 100,0 & 100,0 & 50,0 & 67,6 \\
\hline
\end{tabular}

FONTE: Censo Agropecuérto de São Paulo, IBGE, 1975. 
TABELA L.31 ARADOS POR TIPO DE TRAÇÃO, COLHEDEIRAS E MONOMOTRIZES NA MRH-ASSIS EMI 1970 E 1975

MUNICLIOS

\begin{tabular}{|c|c|c|c|c|c|}
\hline \multicolumn{4}{|c|}{ NUTDRO DE ARADOS } & \multicolumn{2}{|c|}{$\begin{array}{l}\text { COIHIGDEIRUS E MONOREO } \\
\text { TRIZES }\end{array}$} \\
\hline TRACAO & ANTMAL & TRACTOO & MECÂrICA & 1970 & 2975 \\
\hline 1970 & 1975 & 1970 & 1975 & (a) & (a) \\
\hline
\end{tabular}

1. ASSIS

2. BORL

$616 \quad 376 \quad 216$

3. CAMPOS NOVOS PAULISTA

4. CANDTDO HOTA

$\begin{array}{lll}166 & 138 & 34\end{array}$

$271 \quad 309 \quad 43$

610

$37 \quad 83$

$45 \quad 57$

$\begin{array}{lllll}45 & 1 & 1 & 2\end{array}$

5. CRUzLIIA

6. ECHLAPORT

1. HIORIMEA

8. IBIRAREMa

9. IUTECIA

10. Maracat

11. OSCAR BRESSANE

12. PATMITAL

23. paraguacu 'PaUtista

1.200

$525 \quad 185$

136

$17 \quad 13 \quad 10 \quad 15$

30

$11 \quad 319$

502

$\begin{array}{llll}50 & 101 & 70 & 98\end{array}$

$\begin{array}{lll}620 & 304 & 38\end{array}$

422 38

$234 \quad 17 \quad 84$

108

$254 \quad 46 \quad 51$

252

2

55123140

$\begin{array}{lll}430 & 327 \quad 82\end{array}$

96

$\begin{array}{llll}6 & 6 & 69 & 89\end{array}$

$294 \quad 156 \quad 264$

$\begin{array}{llll}2 & 2 & 16 & 17\end{array}$

24. PLATIMA

15. QUATA

\begin{tabular}{rrrrrrrr}
294 & 156 & 264 & 577 & 23 & 29 & 71 & 89 \\
449 & 393 & 62 & 94 & - & - & 2 & 2 \\
1.052 & 917 & 204 & 732 & 11 & 15 & 65 & 83 \\
687 & 854 & 174 & 463 & 61114 & 18 & 22 \\
152 & 173 & 50 & 94 & - & - & 7 & 7 \\
664 & 688 & 87 & 162 & 8 & .5 & 8 & 9 \\
\hline
\end{tabular}

PONTE: Censo Agropecuério de São Paulo, IBGE, 1975.

(a) número de inforinartes

(b) quantidade de equipamentos 
F

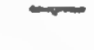

7

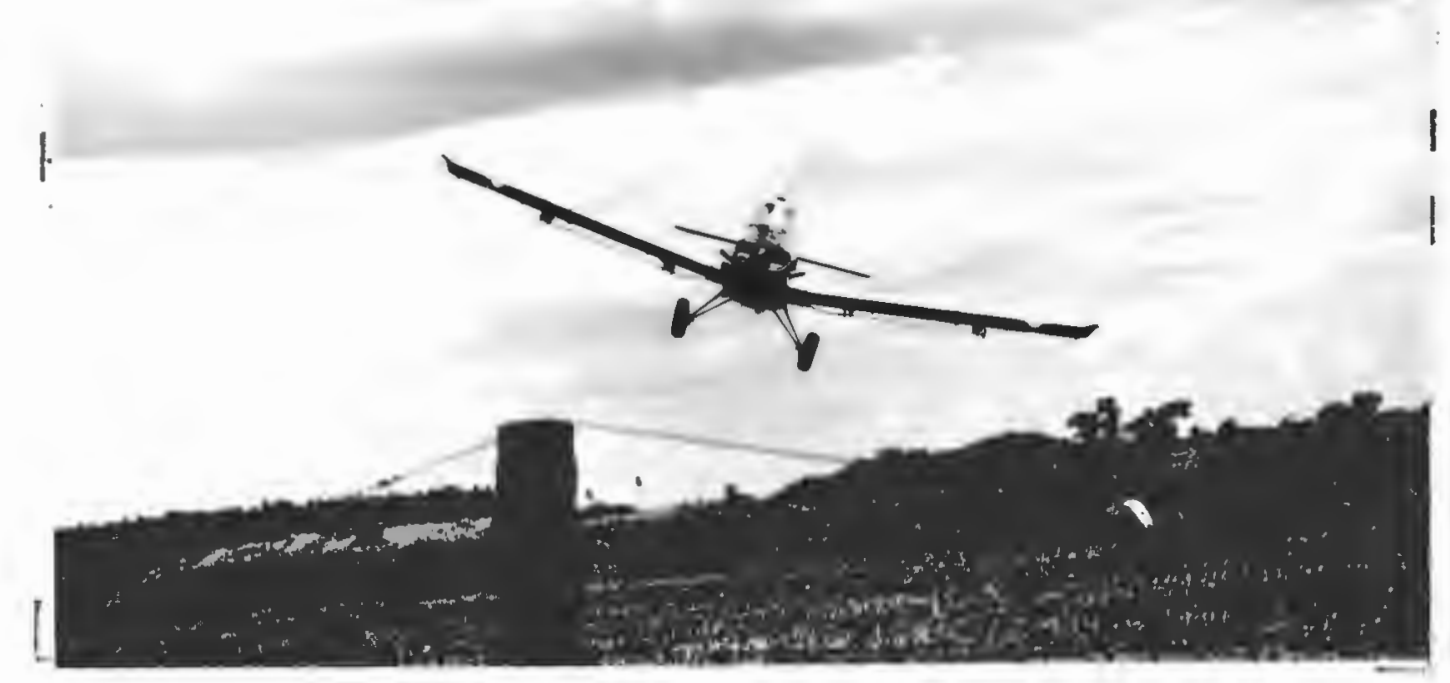

FoTO 3. Avião Agricola utilizado na aplicação de"defensivos"

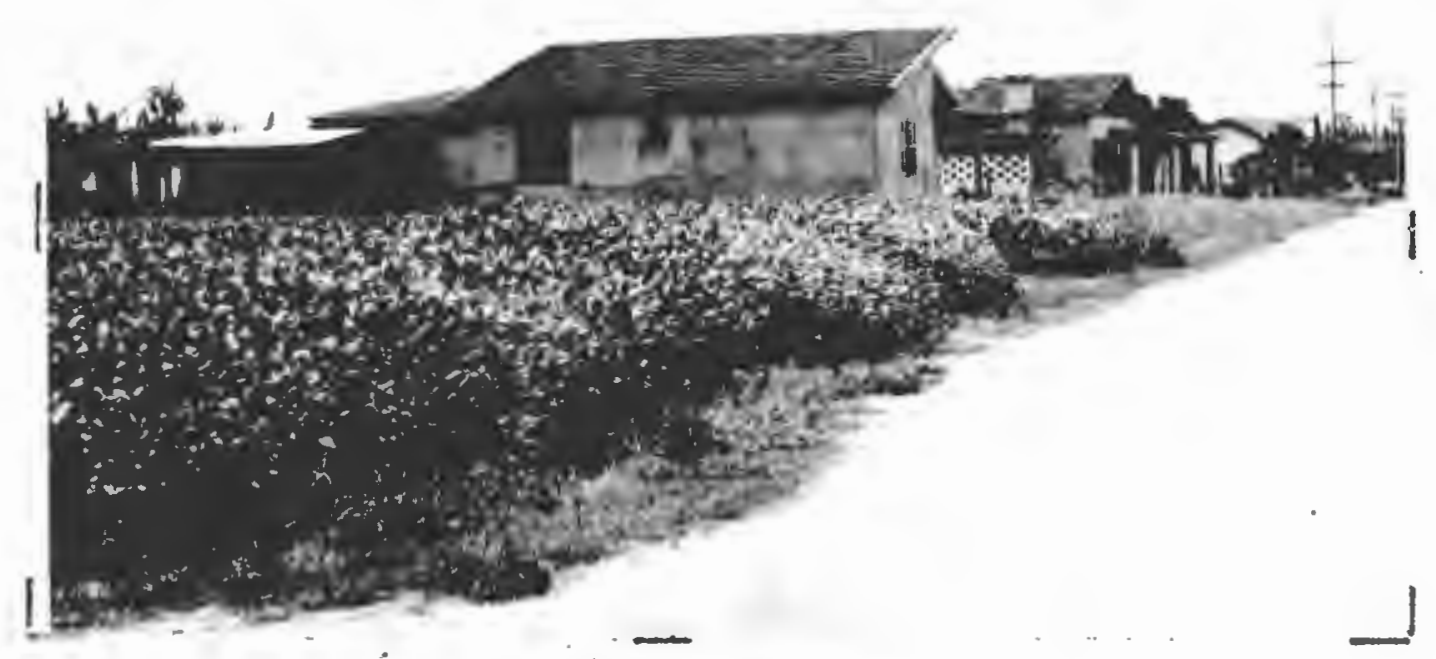

FOTO 4. A soja invade os quintais do núcleo de Tedrinhas. 


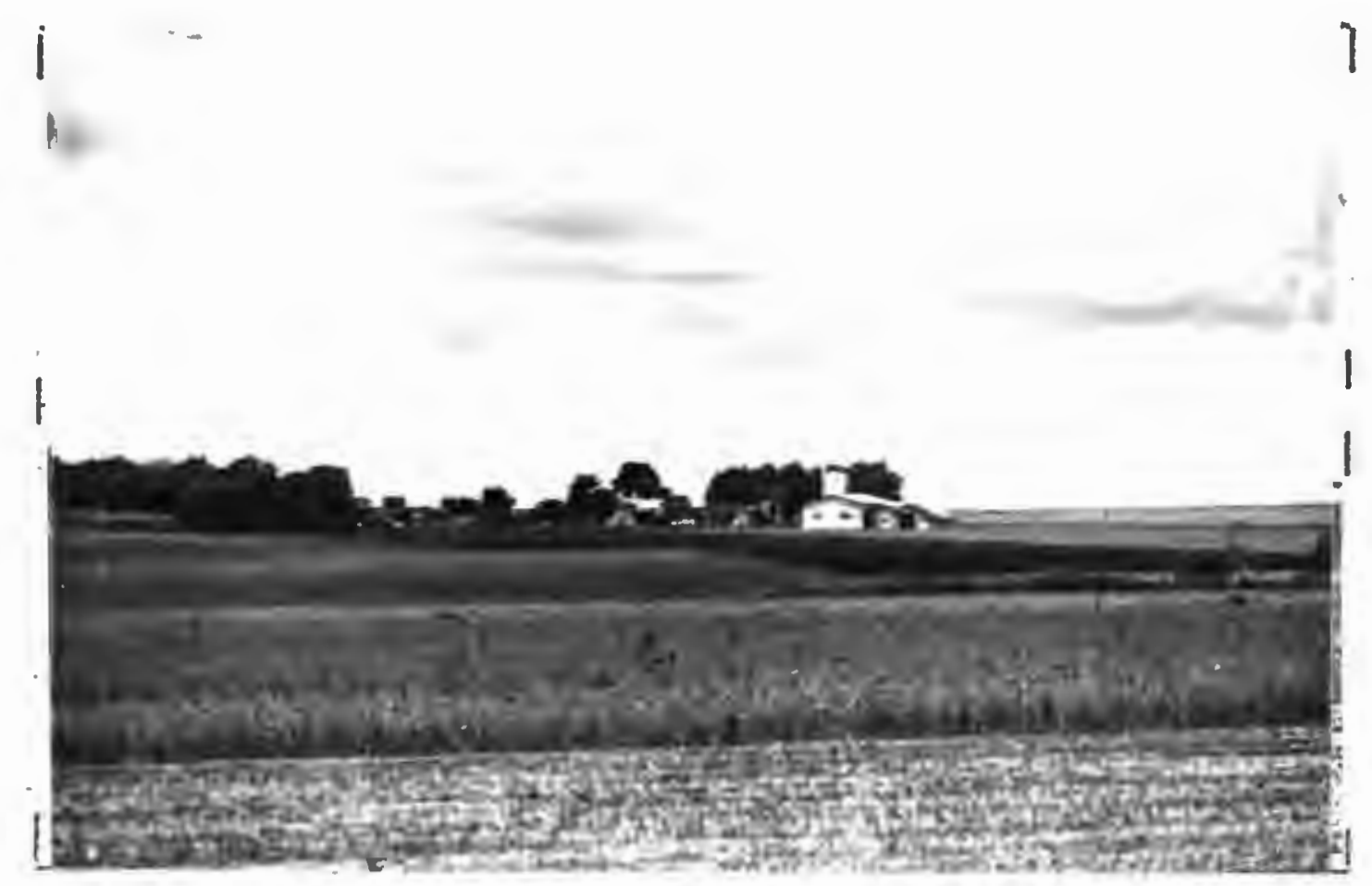

FOTO 7. Um estakelecirento integrado no "Eiriônico

Soja-Trié" em Cruzalia

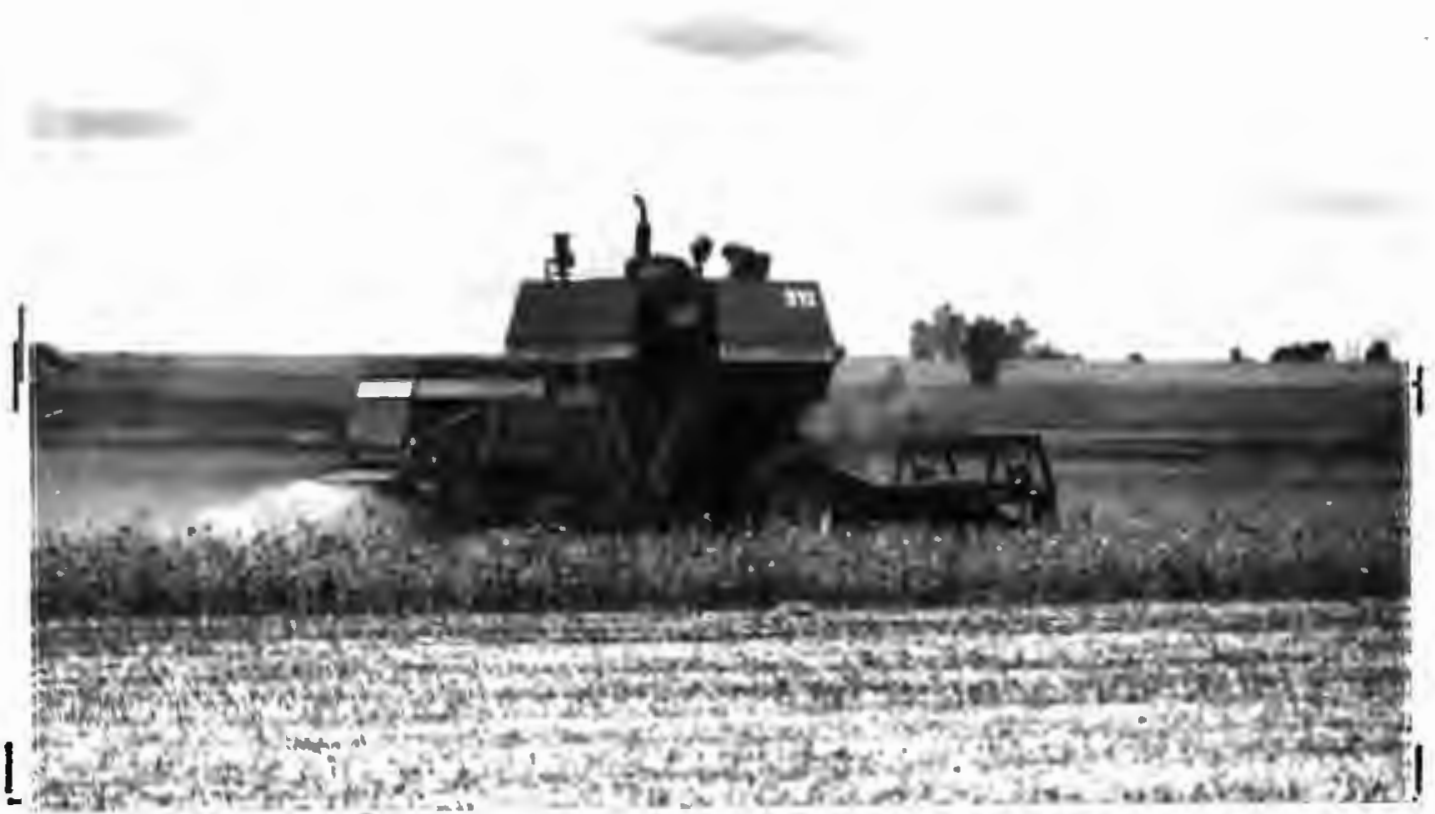

FOTO 8. lionomotriz na colheita do Trigo

Município de Cruzalia 


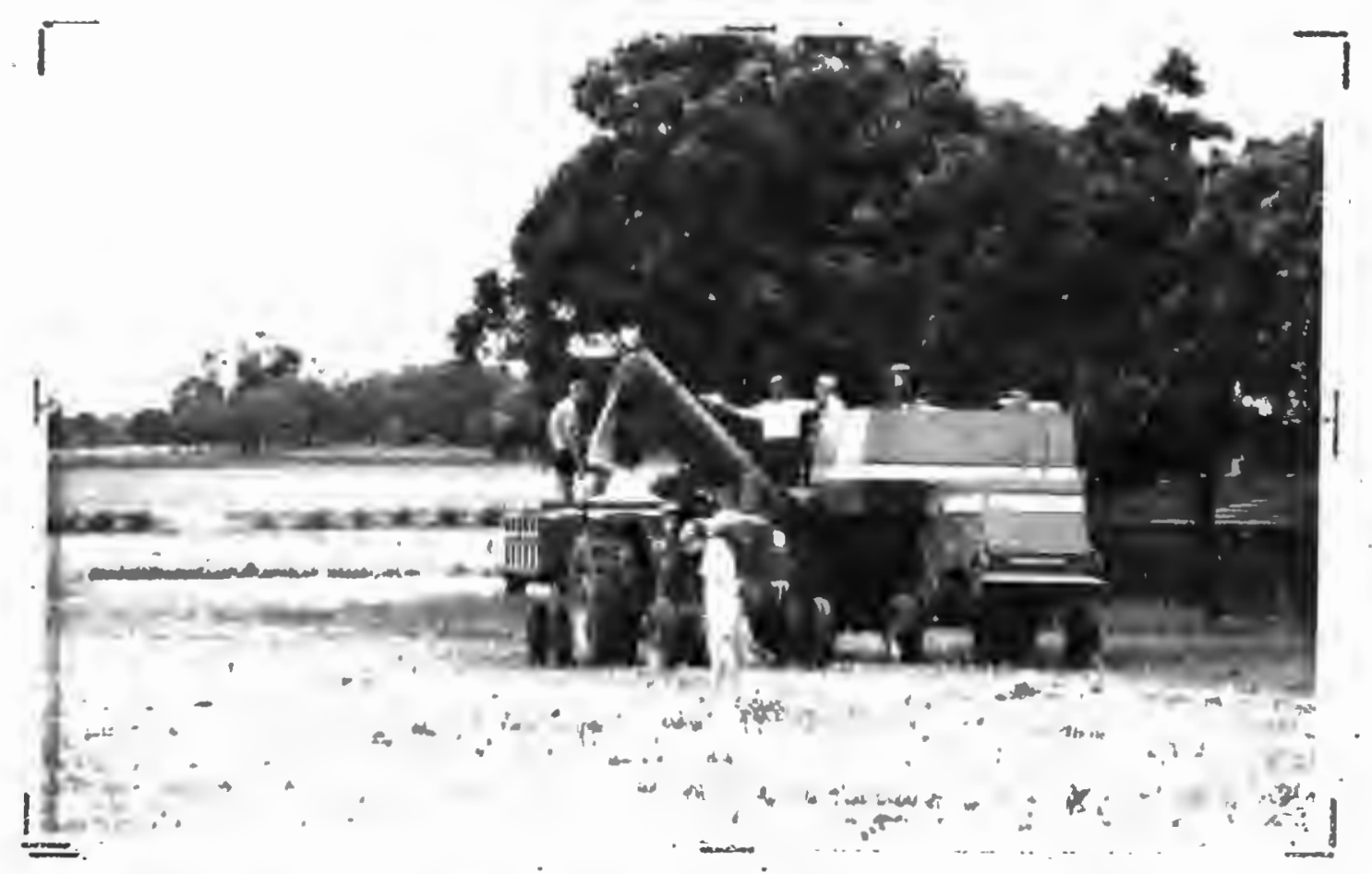

FOTC 9. O sistema de maquinas mais noderno utiliza o sistema " a granél ".

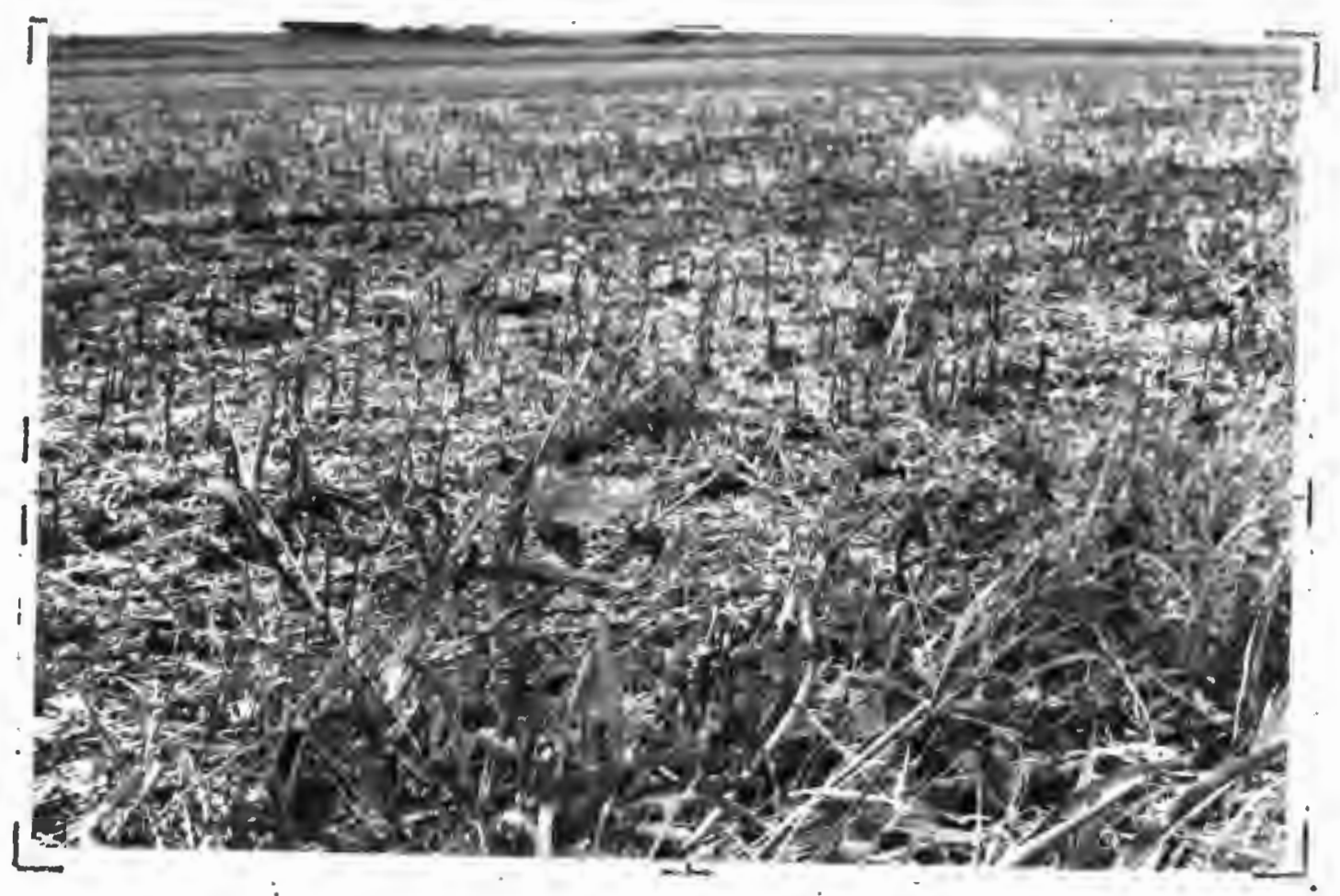

FOTO 10. Resteva do Trigo a ser incorporado

à terra na preparação do canpo para a Soja 


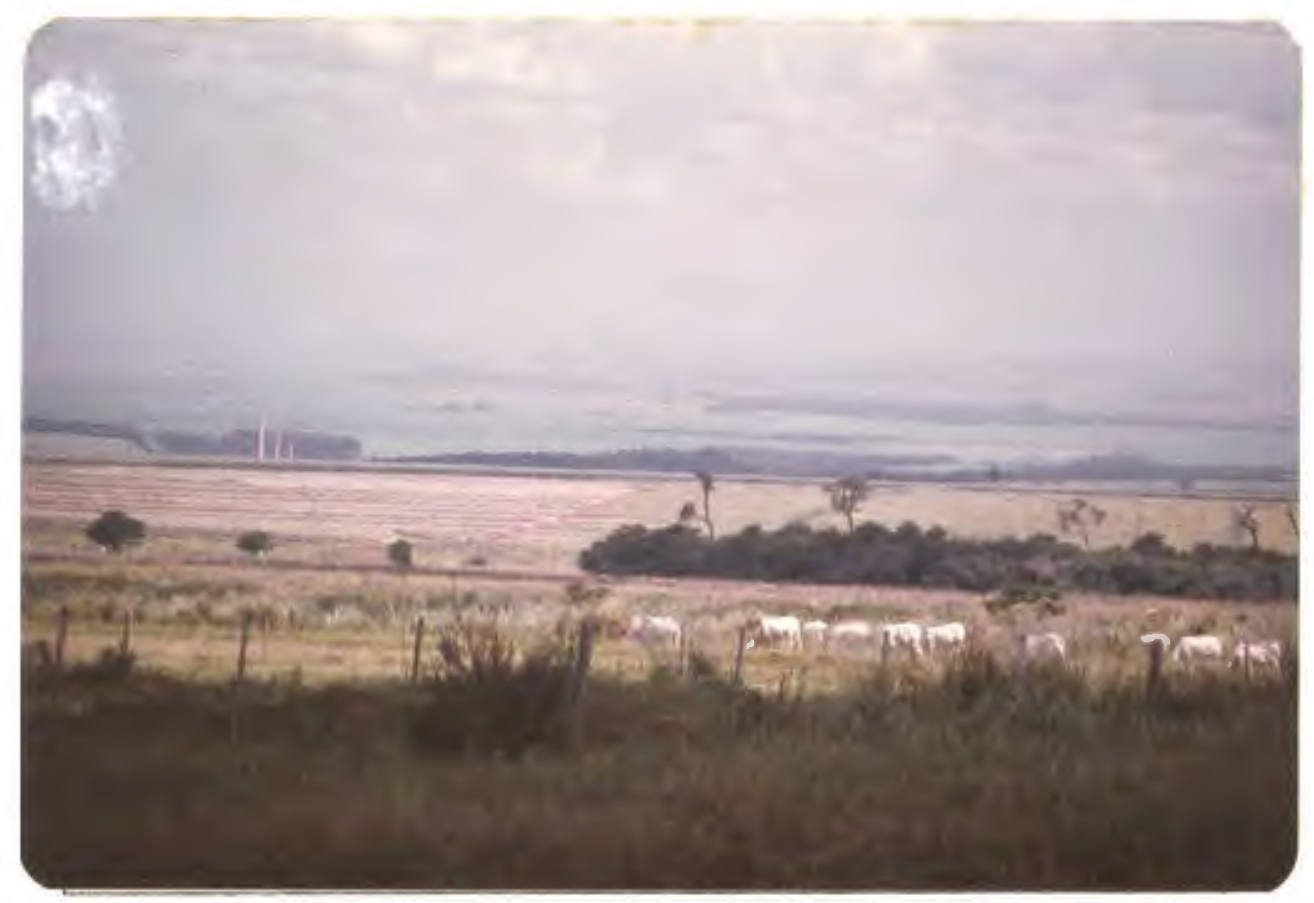

Foto 11. Canaviais, vendo-se ao fundo a Usina Nova América

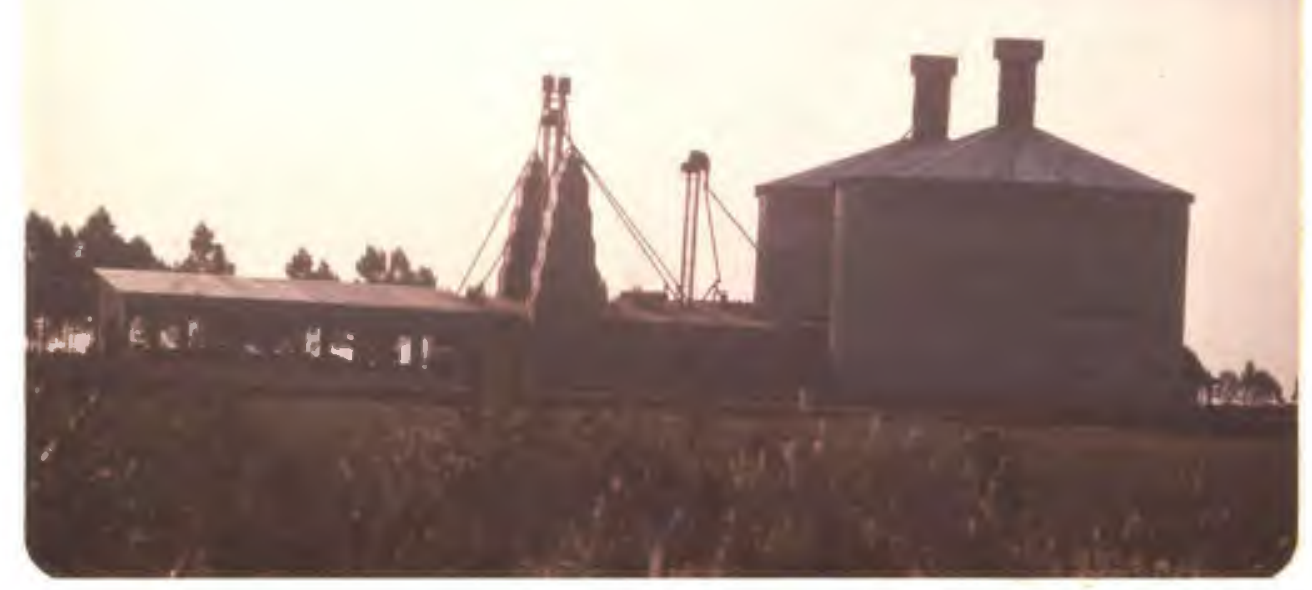

FOTO 12. Secagem e Silagem dos gräos em - Fedrinhas 
Se por um lado a adoção do "binômio soja-trigo" teve um caráter conjuntural e quase aleatório, sua consolidação econômica e a integração da região a um sistema produtivo organizado em bases internacionais, deveu-se à ação deliberada e decisiva do Estado a qual atuou em várias frentes e por me canismos diversos, visando promover transformaçoes nas bases econômicas da agricultura.

Barros, Pastore e Rizziere explicitam a racionalidade inerente às formas de atuação do Estado indicando "que o papel da agricultura no processo de crescimento econômico apresenta cinco aspectos (como em Mellor e Johnston): (a) oferta adequada de alimentos e matérias primas para 0 setor urbano, (b) elaboração decisiva na oferta de divisas, (c)ofer ta de mão-de-obra para as atividades urbanas, (d) contribui ção da poupança gerada no setor primário para a formação de capital na industria, (e) elevação do mercado para os produ tos industriais"(12) e que se consubstanciam na forma puramente econômica.

(i2) Barros, Pastore e Rizzieri - A evolução Recente da Agricultura Brasileira - in Estudos sobre a modernização da Agricultura Brasileira - IPE - USP - Monografias no 9 - São Paulo 1977, p.108. 
Sandroni, ao examinar a questão, lembra que "essas missões que a agricultura deve desempenhar são evidentemente incompatíveis com formas atrasadas ou tradicionais de produção agricola, pois a maioria destes objetivos depende do aumento da produtividade do trabalho na agricultura, o que por sua vez esta diretamente associado à mecanização e à utilização de insumos, créditos, etc. (13)

o Estado dispõe de um arsenal de meios de inter venção com políticas creditícias destinadas a vários momentos do processo produtivo, subsídios, política cambial para as exportações e importações do setor, etc..

A decada de 1970 caracterizou-se por investimen tos vultosos destinados ao desenvolvimento do setor, através de empréstimos a juros reais negativos.

Esses investimentos se deram tanto ao nível do

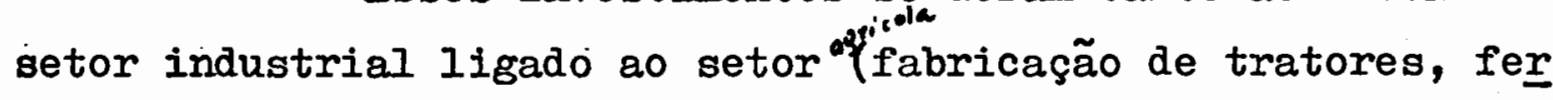
tilizantes) como à capitalização direta da produção da proprie dade, havendo aí uma distinção técnica nas formas de crédito: investimento, custeio e comercialização (I.G.F.).

Atendendo aos pressupostos (missões) acima enumerados, os investimentos foram efetuados de forma concentrada e dirigida preferencialmente às culturas de exportação, as

(13) Sandroni, P. - Questão Agrária e Campesinato - a "Funcionalidade" da Pequena Produção Mercantil - Editora Polis, São Paulo, 1980. 
quais foram responsáveis por mais de 50\% das receitas cambiais no período.

Na década de 1970 ocorreu progressiva redução relativa do número de contratos em relação ao valor investida, - que significa que menos produtores tiveram acesso a mais ca pital-dinheiro. 


\subsection{As novas bases do sistema creditfcio}

A partir de 1937 começou a ser organizado no Brasil, de forma racional, o Sistema de Crédito Agrícola pela criação da Carteira de Crédito Agrícola e Indústria (CREAI) do Banco do Brasil.

Embora tenha sido um impulso decisivo no sentido de organizar junto ao sistema bancário os dispositivos ne cessários para uma plena expanşão do crédito formal, mais com patível com as necessidades da agricultura, seu efeitofoi bas tante localizado, podendo ser lembrado o surgimento de cultura do arroz irrigado no Rio Grande do Sul em bases técnicas e de produtividade bastante avançadas e verdadeira alavanca do avanço na organização técnica de produção no Rio Grande do Sul.

Somente a partir de 1965 com a criação do Siste ma Nacional de Crédito Rural (SNCR) ${ }^{(14)}$ forçando a participação de toda a rede bancária foram ampliados os recursos cre ditícios para o setor agrícola e principalmente reforçados os mecanismos de controle do encaminhamento dos recursos credití cios tanto para atividades como para regiões.

Característiça básicas do SNCR são as seguintes:

(14) Lei No 4829 de $05 / 11 / 1965$ regulamentada peio décreto № 58380 de $10 / 05 / 1966$ 
(a) desqualificação de segmentos fora do setor (p.ex , comerciantes) para obtenção de crédito agrícola; (b) exigência de orçamento detalhado por parte do proponente, com o montante e a época de todas as despesas necessárias ao projeto .. "; comprovação da rentabilidade dä aplicação (15); (d) fiscaliza ção e controle dos dispêndios do empréstimo.

Quanto aos prazos de pagamento os montantes fi nanceiros e taxas de juros sofreram varịações na década de 1970 tendo em vista as necessidades de atuação do Estado no setor, a disponibilidade monetária e as dificuldades de administração da expansão dos meios de pagamentos afetando diferencialmente as diversas atividades e regras envolvidas.

Os instrumentos de crédito rural, O SNCR Oficia lizou três tipos de títulos ${ }^{(16) ;}$ (a) cédulas rurais, notas prô missórias rurais e duplicatas rurais.

Os títulos mais utilizados são a cédula rural tanto hipotecária como pignoratícia para investimento e cus teio e menos frequentemente, a promissória rural.

As medidas que permitiram ampliar os recursos en caminhados ao crédito agrícola eståolizadas ao contingenciamen to dos depósitos de conta corrente dos bancos particulares. A

(15) Geralmente o próprio banco produz esge orçamento para o produtor.

(16) DL 167 de $14 / 02 / 1967$ 
resolução 69 estipulou a apłicação de 10\% dos depósitos de conta corrente no crédito agrícola, ou seu recolhimento ao Banco Central, que através de um Fundo Nacional Refinanciamen to Rural (TNRR). (IT) para redesconto desses financiamentos, que em 1965 com um montante de cr\$590 milhões, esteve assim composto:

Composição do FNRR em 1969 Cr\$ 590 milhões $=100$

Depósitos de Bancos Particulares (18)

Confisco Cambial sobre exportação do Café 22,0

Acordos do Trigo (PI 480)

14,0

Empréstimos diversos da USAID

12,0

Banco Interamericano de Desenvolvimento

12,0

Outros

16,0

Muito embora esses empréstimos sejam constantemente considerados subsídio governamental à agricultura, tendo em vista que grande parte dela provel de contas correntes que não remuneram os depósitos nem mesmo contam com 0 benefício da correção monetária, o repasse desses montantes de $6 \%$ de ju. ros a.a. e $45 \%$ de correção monetária como estão sendo pratica das, em média consiste num ganho, embora menor, para o sistema financeiro às custas da agrịcultura, a qual se capitaliza a custos amplamente socializados.

(17) O FNRR e o FUNDEPE (Fundo de Desenvolvimento de Pesquisa) são sub- contasdo FUNAGRI (Fundo Geral para Agricultura e Indústria), fundo geral administrado pelo Banco Central. (18) Segundo resolução 69. 
A partir de 1970, as aplicações do SCNR são orí entadas por programas regionais, que selecionam as atividades agrícolas e as regiões prioritárias através dos PESAC (Progra màs Estaduais de Aplicação de Crédito Rural).

Paiva, Schattan e Freitas indicam que o esquema citado "encaminha os fluxos financeiros para os objetivos desejados,... ... não apenas para planejar e por em execução uma série de medidas em favor da agricultura, como para receber os recursos financeiros provenientes das organizaçoes internacio nais que desejam financiar a realizacão de projetos especiais em nosso país mas que exigiam uma contrapartida proporcional de recursos creditícios por parte de nosso governo." (19)

O sistema de crédito rural passa a ser então o principal instrumento de política agrícola, através do qual fo ram implantados dezenas de grandes programas nacionais e pro jetos relacionados ao setor. Nesse contexto aparecem inteiramente integrados a ação do Estado $e^{2 \sqrt{d}}$ os complexos monopolísti cos internacionais no processo de reconversão econômica da agricultura no Brasil.

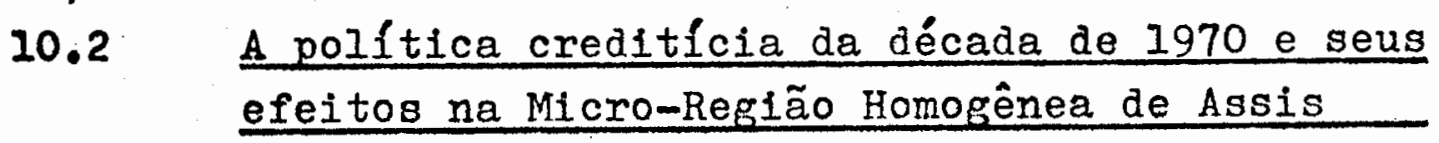

Entre 1969 e 1976 os financiamentos concedidos a.os agricultores aumentaram $344 \%$, enquanto a produção agrico la cresceu em proporção bem inferior. Essa expansão caracteri

(19) PAIVA, Ruy Miller e SCHATTAN, J. e FREITAS, Cláudio P. de. 1973: -"Setor Arícola do Brasil: Comportamento Ecolr. nômico, Problemas ePossibilidades". Secretaria de Agricui cultura do Eat. de São Paulo. São Paulo, 1973. (O grifo \& nosso). 
zou-se pela concentração dos financiamentos tanto por região como por atividades, beneficiando seletivamente os agricultores, e abrangendo cerca de $20 \%$ dos estabelecimentos em todo o país, ou seja, 1.076 mil contratos(20) para cerca de 5 mil es tabelecimentos (2l).

Em termos agregados os maiores beneficiários es tão nạs regiões Sul e Sudeste e, depois de 1975, na Centro Oeste.

No que se refere às atividades, os maiores bene ficiários foram os produtos de exportação, principalmente aqueles que estavam contribuindo para o reequilíbrio da balan ça de pagamentos (café e soja, principalmente) em fase de mer cados favoráveis.

Dentre os produtos de abastecimento interno, os mais beneficiados foram o arroz e o trigo. Este último produto parece ter esgotado as possibilidades de expansão por vol ta de 1974, dentro dos processos técnicos atualmente adotados, tendo ém vista que a área plantada deixou de responder à expansão do crédito ( $v$. gráfico 5 ), como do resto as demais. culturas.

(20). dados do BACEN

(21) dados do IBGE 
GRAFICO 5 - EVOLUÇO DA AREA COLHIDA E DO CREDITO DE CUSTEIO FARA O TRIGO (1969-78) -(CHIIHCES E 1000 HA)

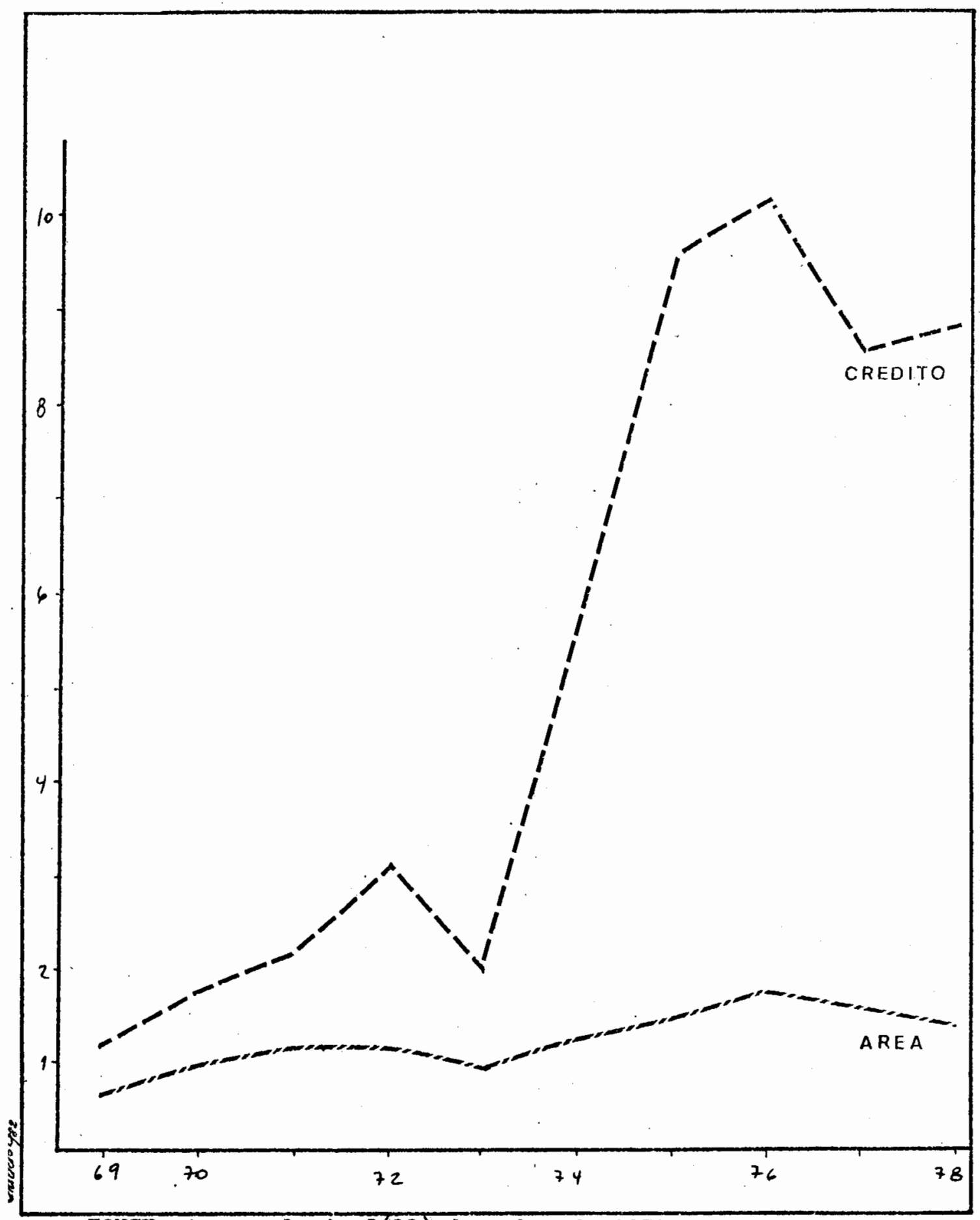

FoNTE: Agroanalysis 3(11), dezembro de 1979 
TABETA 1.32

BRASII. Expansão do Crédito para Custeio da Atividade Agrícola por Culturas, 1969/1975, Bn Cr\$ mil de 1970 (1)*

CULTURAS

$(1969 / 1975)$

Contribuição de

cada Produto pa

ra $(\operatorname{Em} \%)$

$\begin{array}{lrr}\text { Algodão } & 66.450 & 0,80 \\ \text { Amendioim } & 11.887 & 0,15 \\ \text { Arroz } & 1.433 .229 & 17,15 \\ \text { Cacau } & 63.986 & 0,77 \\ \text { Café } & 808.955 & 9,68 \\ \text { Cana } & 992.696 & 11,88 \\ \text { Feijão } & 100.562 & 1,21 \\ \text { Mandioca } & 15.991 & 0,20 \\ \text { Milho } & 816.002 & 9,77 \\ \text { Soja } & 1.894 .730 & 22,67 \\ \text { Trigo } & 1.255 .358 & 15,02 \\ \text { Cooperaticas } & 56.553 & 0,68 \\ \text { Outros } & 841.945 & 10,08\end{array}$

Total

8.358 .344

100

FONTE: Censo Agropecuário de 1970, FIBGE.

(*) Razão entre o percentual de crédito obtido e o percentual de participação no valor de produção agropecuária nacional, mul tiplicada por 100. 
TABELA 1.33

BRASII - Relação entre crédito de custeio e área colhida de arroz, feijão, milho, trigo e soja - 1969-78

\begin{tabular}{lllccc}
\hline & $\begin{array}{c}\text { Arroz } \\
\text { Cr\$/ha }\end{array}$ & $\begin{array}{l}\text { Feijáo } \\
\text { Cr\$/ha }\end{array}$ & $\begin{array}{c}\text { Milho } \\
\text { Cr\$/ha }\end{array}$ & $\begin{array}{l}\text { Trigo } \\
\text { Cr\$/ha }\end{array}$ & $\begin{array}{l}\text { Soja } \\
\text { Cr\$/ha }\end{array}$ \\
\hline 1969 & 1.698 & 226 & 583 & 1.661 & 1.529 \\
1970 & 1.370 & 292 & 663 & 1.858 & 1.585 \\
1971 & 1.263 & 230 & 544 & 1.919 & 2.366 \\
1972 & 1.634 & 233 & 543 & 2.671 & 2.858 \\
1973 & 2.273 & 630 & 1.060 & 2.237 & 3.734 \\
1974 & 3.772 & 535 & 1.167 & 4.742 & 3.975 \\
1975 & 5.103 & 523 & 1.527 & 6.546 & 4.605 \\
1976 & 4.655 & 770 & 1.524 & 5.715 & 5.011 \\
1977 & 4.304 & 1.205 & 1.105 & 5.430 & 4.608 \\
1978 & 3.789 & 1.040 & 1.248 & 6.257 & 4.186 \\
\hline
\end{tabular}

Fonte: ". : Dados Brutos: Crédito Rural-;Dados Estatísticos do BACEN; Amúrio Estatístico da FIBGE. 
En termos agregados o binômio soja-trigo benefí ciou êl cerca de $38 \%$ da expansão do crédito para custeio en tre 1969 e 1975, vindo em seguida o arroz (17\%) e a cana (12\%) conforme Tabela 1.32.

Em 1972 as exportaçōes de produtos primários contribuiram em 52\% da pauta de exportações, sendo que a contribuição da soja em grão, farèlo e torta, já contribuiar um $7 \%$ do valor. Esse dado vem reforçar a expansão do crédito à produção de soja, com reflexos na área plantada, observando-se forte expansão na luicro Região Homogênea (IIRH) de Assis.

A instituição do "Plano de Autosuficiência em Trigo" em 1974, esgotou-se em 1979, sem contudo apresentar os resultados esperados.

0 alto volume de créditos liberados para o cultivo de trigo permitiu a sustentação dobinômio na região, tẹdo em conta as frustrações de safra de soja de 1978 e 1979.

A característica da década de 1970, por outro la do, como em outras regiões, a dotação de créditos deu-se de' forma seletiva, deixando de ter acesso a ela as culturas. de alimentos.

No período de 1969 a 1977 as razões entre o cré dito de custeio e a área plantada para a soja e o trigo de um lado, e para o arroz, o milho e o feijão de outro, apresentam comportamentos bastante diferenciaidos. 
O trigo apresenta um comportamento oscilante, 0 que se explica em parte pela sue complementariedade econômica em relação à soja, entre os adotantes do binômio. Quanto à so ja, embora apresente incrementos mais moderados que o trigo nas relações entre crédito de custeio e área colnida, a área de plantio aumentou 7,5 vezes, enquanto o custeio aumentou 23 vezes entre 1969 e 1978. Quanto às demais culturas, apresenta se um comportamento semejhante.

A cultura do trigo é em ceral menos remunerativa que a cultura da soja, e representa maior risco por intempéries e pragas.

Dessa forma, ao adotar o binômio na MRH-Assis , apresentam-se as áreas plantadas de trigo bem inferiores à área da soja, jndicando claramente a complefariedede do trigo na formação . eçonômica do binômio como por razões puramen te de ordem técnica. 
Tendo em vista que a rotação das culturas se dá por sucessão num mesmo ano safra, e que ocupam o solo durante quase todo o tempo, resta ao agricultor muito pouco tempo para preparar o solo entre uma cultura e outra. O fato de de $\underline{i}$ xar uma parte de terra desocupada, permite o preparo do solo para soja, ainda quando está sendo processada a cultura do trigo.

Tendo em vista que a composição dos campos de cultivo em variedades precoces e variedades tardias climina, em parte, os riscos de perdas por intempéries enquanto otimiza a utilização das colhedeiras, que podem colher um campo en quanto outro está em maturação, é de se compreender os limites impostos à expansão da área plantada, as quais não mais res pondem à expansão do crédito.

Os volumes de crédito oferecidos à região foram entretanto fundamentais para a sua integração muito embora sem a. contrapartida econômica que se tinha como expectativa.

o caráter concentrado em áreavem atividades, da oferta de créditos, repetiu-sc - entre produtores, iiuma política que favorece cultivos de exportação integrados por processos produtivos organizados à escala mundial, tendo por objetivo principal o equilíbrio dos fluxos cambiais. Evidentemen os pequenos produtores e os não proprietários, em geral, res ponsáveis por grande parte da produção de alimentos, foram marginalizados, tanto a nível nacional como a nível regional. Com efeito, o acesso ao crédito, para as diversas culturas, é desigual. 
Dessa forma, o acesso aos meios modernos produção tendem a se dar de forma seletiva, só para aqueles que possam integrar-se ao complexo soja, e esta integração es ta condicionada a certos potenciais técnicos, como módulo fun diário tecnicamente econômico, capacidade de terras como suporte para : adoção do processo produtivo. Isto significa que os pequenos proprietários descapitalizados e os produtores sm terra sofrem um processo de marginalização progressiva a par tir da propria política creditícia de custeio.

Os pequenos produtores capitalizados, tendo acesso ao crédito de investimento e ao custeio de algumas cul turas economicamente atrativas e especialmente rendosas na re gião, puderam manter-se, eliminando o arrendamento e a parceria, mecanizando a propriedade e trabaljando na base familiar de produção. Os produtos cujo custeio foram amparados pelo crédito agrícola foram o arroz e o milho. Isto explica princi palmente a expansão de área do arroz plantado na região, nos primeiros anos da década de 1970.

Até 1978 a formação dos orçamentos de custeio eram baseados nos preços mínimos pré-fixados pelo governo. Tendo em vista que os preços mínimos se definiam politicamente, e às vezes, por isso mesmo, tardiamente (a) obrigavam-se os produtores a tomar empréstimos no mercado para cobrir o custeio real de suas lavouras, ou para dar início ao ciclo produtivo, que no binômio soja-trigo tem margens estreitas de tempo para preparo da terra. 


\subsection{O sistema creditício e a reproducão do processo}

Muito embora o sistema creditício tenha passado por uma racionalização operacional e reforçado pelo contin genclamento dos montantes de contas correntes em mãos de bancos privados e canalização para crédito rural via Banco Central e com isso tenha aberto amplas possibilidades de aces so ao crédito há que lembrar, como foi demonstrado anteriormente, o caráter seletivo do sistema de crédito, contemplando os proprietários em detrimento dos demais produtores, e os grandes em detrimento dos pequenos. A "racionalidade" dessa prática é encontrada na utilizaçäo do sistema creditício como meio de induzjr e manter a aloção de processos produtivos mais avançados tendo por objetivo a (a) produtividade e a seração de excedentes para a exportiação e (b) o consumo crescente de produtos industriais pela agricultura.

Isto não é senão a rotação induzida do capital em suas diversas formas, tendo em vista a elevação dos seus padrões de acumulação, - rotação, esta, extendida à es. cala internacional, produzida e administrada pelo Estado.

A garantia de manutenção do sistema induzido se assenta sobre as formas de contrato de crédito.

Muito embora a simplificação em relação às formas de créditos oferecidos anteriormente a 1965, via CREAI, o processamento é bastante burocratizado, e altamente contro- 
lado como se verá.

As cédulas rurais explicitam como se dá através do sistema creditício na matenção do processo produtivo, (a) pelo controle dos parấmetros técnicos na confeç̧ão das propostas orçamentaís de custeio:, (b) vinculandooseguro agrícola (Pró Agro) à adoção de processos produtivos paðronizados independente mente da conjuntura, (c) pela introdução de cláusulas especiais vinculando os empréstimos a certos padrões técnicos de preparo do solo o que induz ao consumo de máquinas e cquipamentos (e acaba por captar o produtor para a órbita do capital financeiro do qual ele se tornará "etemamente" dependente), (c) pela vinculação do pagamento do empréstimo à comprovação de consuno dos insumos , a ser feito diretamente pelos for necedores.

Um dos casos de custeio: excminados nos trabalhos de campo demonstra: os padrộes de alocaçẽo do crédito como segue: 
1.1 AQUISIÇÃO DE INSUMOS

- SEHENTES ......... IMED.

- OUTROS

OPORT.

$21,4 \%$

$26,6 \%$

1.2 TRABALHOS CULTURAIS

- preparo da terRa, PLANTIQ, ADUBAÇÃO, CONSERVAÇÃO DO SOLO.. IMED. $\ldots . .$.

- APLICAÇÕES: INSETICIDAS, HERBICIDAS OPORT $-\quad \ldots 37,0 \%$

2 COLHEITA OPORT

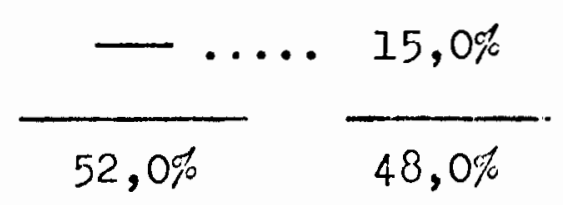

TOTAIS

c.f. Cédula Pignoratícia, apêndice 1 , documento 2 .

Os números acima demonstram claramente o papel do crédito na transformação da agricultura como mercado de produtos industriais. (ver apêndice l)

Todo o processo de levantamento de crédito de custeio da atividade agrícola tem início por um orçamento detalhado das diversas fases do processo produtivo e dos dispen dios relativos a cada um deles e da declaração da produtivida 
de média esperada; é exigida a comprovação de "economicidade" do projeto.

Em geral os orçamentos são compostos dentro do próprio sistema financeiro - com a anuência do tomador - qual utiliza, na formação do orçamento, dois parâmetros esta belecidos regionalmente: (a) a produtividade esperada e (b) a capacidade potencial da terra, advindo daí uma série de consequências, como se verá.

A utilização desses parâmetros estão por conta da racionalização da produção internamente ao sistema bancário, que embora examine cada proposta de crédito individualmente do ponto de vista legal, não o faz contudo, em termos técnicos.

A formação do orçamento sobre esses dois parâmetros tem como consequências imediatas (a) uma tendência ao ni velamento das empresas, as quais deixam de competir entre si na obtenção de lucros extraordinários, (b) tendo em vista que a terra é usada apenas como suporte , a capitalização forçada de terra mélhor, para além de seu patamar de maximização de Iucratividade impedindo a formação de Iucros extraordinários advindos de produtividade natural da terra, (c) a utilização de determinados padrões técnicos de produção como o com 
bate ä erosão, terraceamentọ, curvas de nível o que força por sí só a vinculação a um contrato de investimento tendo em vis ta a necessária obtenção de maquinárias adequadas ao preparo da terra.

Em geral a adoção desses padrões técnicos está vinculada também a aceitação do Pró_Agro, - Seguro Agrícola por parte do sistema creditício. Esses mecanismos forçam um superconsumo de insumos e maquinarias e o setor agrícola cumpre assim seu papel de mercado estável desses produ`os industrializados.

A estabilidade garantida dos mercados aos produ tos industriais transfere a instabilidade ao setor agrí cola. Praticamente forçado a se manter na produção mesmo nos anos ruins para fazer frente ao cumprimento de seus contratos de investimentos, vềm se impossibilitados de fazer variar os montantes de capital de custeio e de produtividade para manter suás taxas de iucro. .

Ao mesmo tempo que o sistema creditício abre amplas perspectivas de capitalização na agricultura por um processo de "transferência" de capital, ele contribui para a descapitalização nos "anos maus" obrigando os produtores a ne gociações coletivas com o governo tendo em vista a adoção de medidas extraordinárias como a ampliação dos prazos para saldar compromissos financeiros.

Tendo em vista que o montante de recursos dispo 
níveis para o setor administrado via FNRR, e ainda, que esse fundo atende não sió a produção agrícola direta, mas a todos os setores envolvidos com a produção (indústria de máqui nas e tratores, fertilizantes, cooperativas armazéns, etc..) os níveis de capitalização dependerão sempre, de um jogo de grupos de pressão negociando junto ao governo onde os diversos grupos têm : acesso desigual.

A manu tẹçõo dos padrões técnicos, via sistema creditício, pela equalização da composição dos meios de produção promovem ainda a consolidação regional de uma área "especializada" atuando junto com outros fatores na formação da "zona agrícola", dentro das quais as possibilidades de obtenção de lucros extraordinários pela diferença de potent cial produtivo da terra se equalizam.

As possibilidades de substituição de produtos torna-se cada vez mais limitada tendo em vista as imobiliza ̧ões regionais em meios de produção até um momento em que os meios existentes passam a determinar a produção. A trans formação de uma zona agrícola em.. outra não pode ser feita senão a custa da destruição de pelo menos uma parte do capí tal f1xo; e sua consolidação é feita por um processo de renovação constante dos meios de produção, determinada externamente, dentro de um processo de competição entre as áreas, 1. pela produção a custos tendencialmente mais baixos em termos absolutos, isto é; em termos de competição internacional.

A formação e consolidação de zonas agrícolas 
está poia afeta ao processo da divisão intemacional do trabalho, e se assenta em certos parâmetros de ordem natural, como condições ecológicas adequadas a uma melhor produtivida de, mas sobretudo, esta centrado na possibilidade de aumento da velocidade de rotação do capital fixo, isto $\dot{\theta}$, do capital produtivo imobilizado nos meios de produção, tendo por origem a indústria.

A estratégia encontrada na região para fazer frente ao super_consumo forçado de insumos são possíveis aos produtores mais capitalizados (a) pelo plantio de uma área maior 3 do que as contratadas pelo custeio, distribuindo os insumos segundo a "racionalidade " do produtor, (6) pela manutenção de outras culturas ou pastagens para onde são desviados os insumos adquiridos em excesso.

Nesses casos, condições climáticas adversas su pervenientes co ciclo produtivo que possibilitam o acionamento do Seguro Agrícola i irá constatar uma quebra de safra em certos casos superior àqueles previstos para os casos em que o processo técnico foi cumprido integralmente.

Até 1978 o Proagro cobria 80\% do custeio da parte comprometida. No caso do uso de expedientes acima men cionados o se Euro passa a cobrir mais de 100\% do custeio re al. Se ocorreram investimentos em pastagens ou fornecimentos da cana de açúcar, por exemplo, o produtor poderá capita Iizar-se, iludindo o sistema. Este expediente, entretanto, só é possível para os grandes produtores que possuem mais terras ou que podem adquiri-las no cerrado para melhora mento,e por aqueles que têm acesso às técnicas de avaliação 
das condições potenciais de produção da terra e de dosagem econômica de corretivos tendo em vista a produção mais lucrativa. 


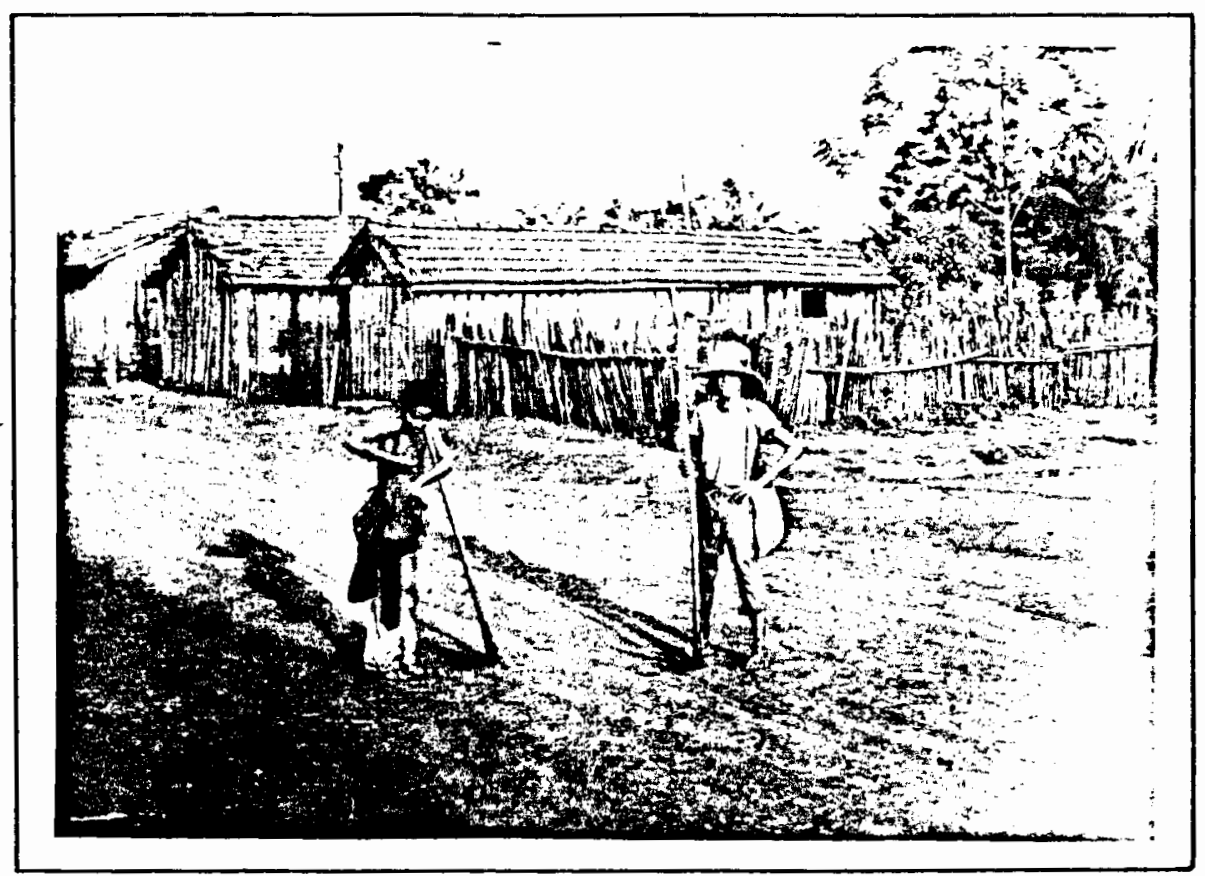

Foto 4a. "Meninos Trabalhadores Municipio de Cândido Mota

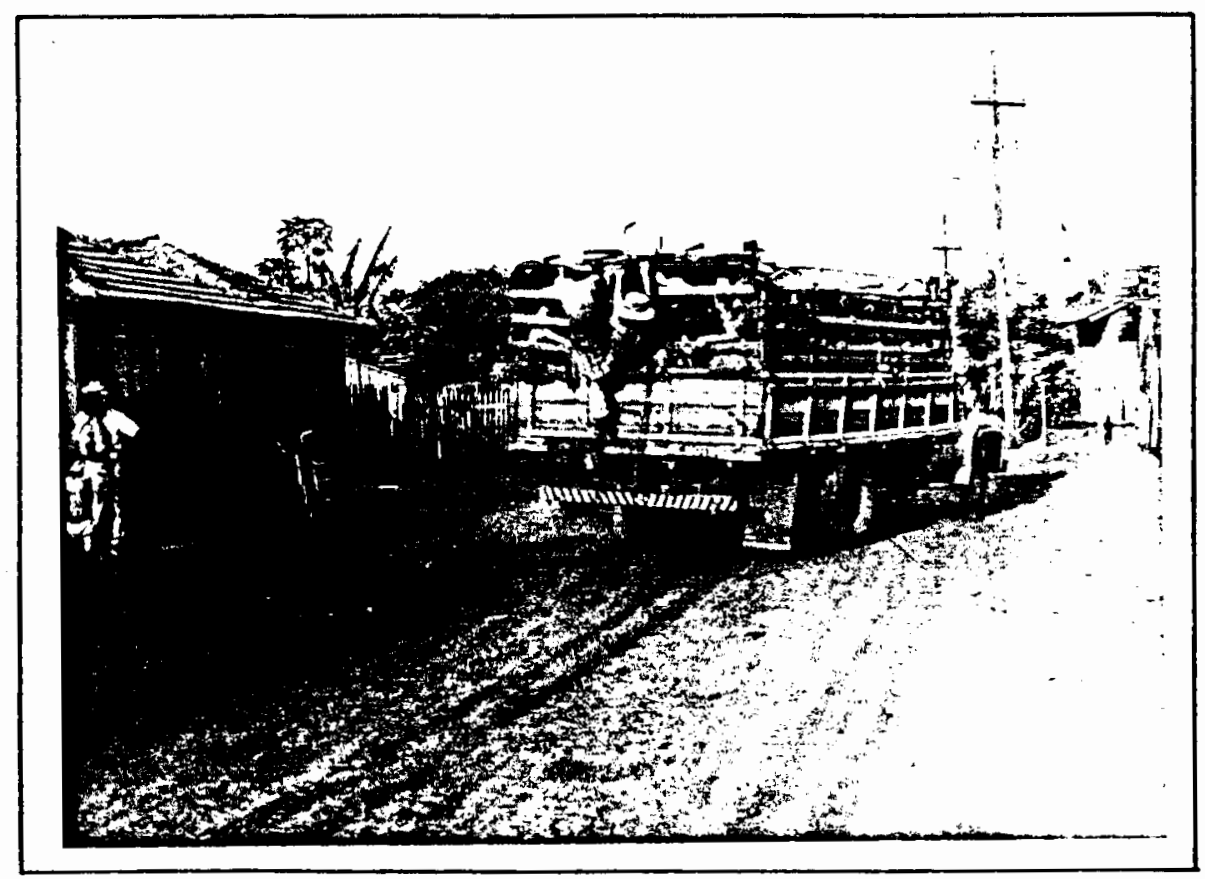

Foto 4b. Caminhão de "Boias-Frias" em Cândido Mota-SP 


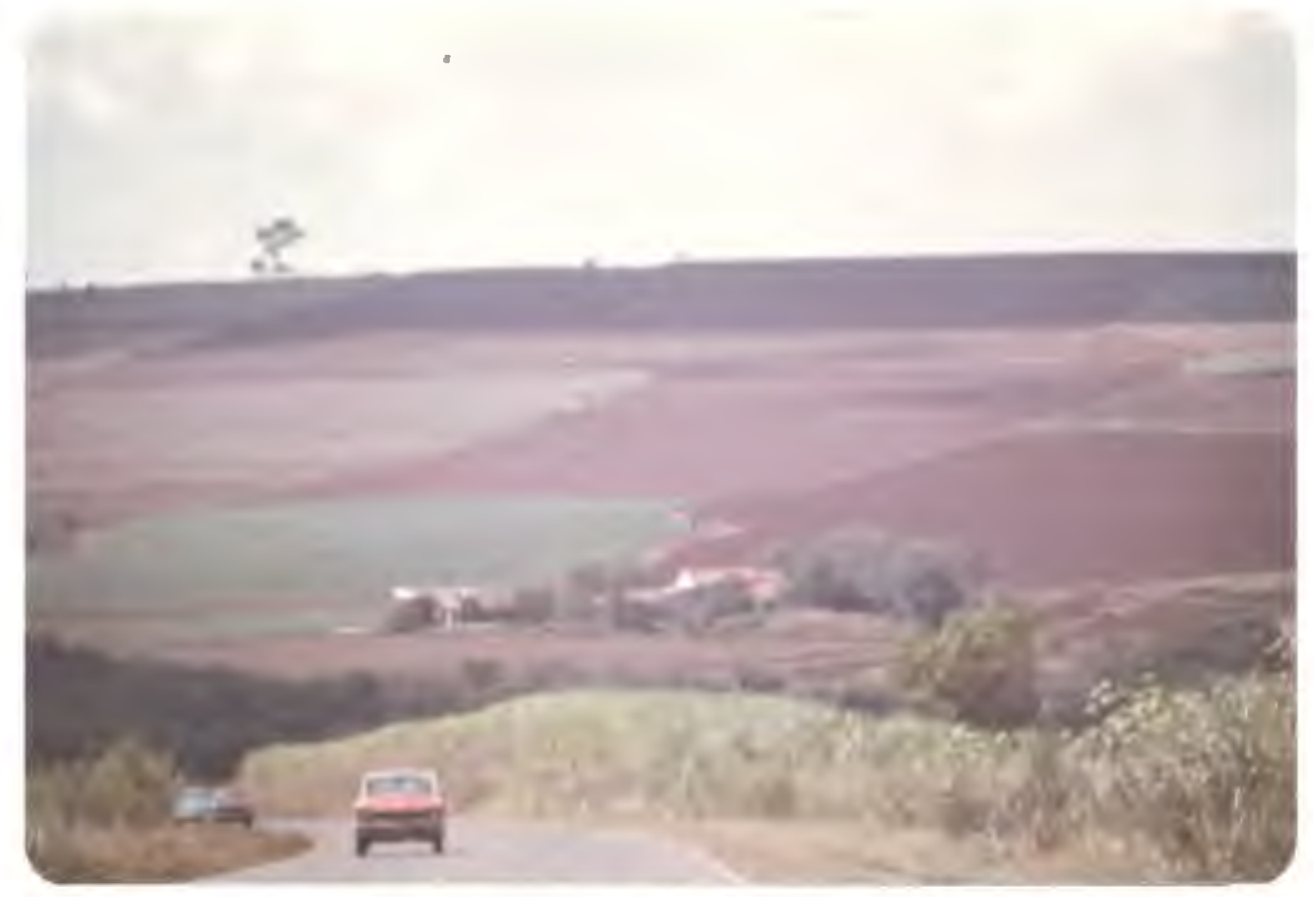

Toro 5. Campos em preparo pera o pientio. - Itunicípio de raracaí

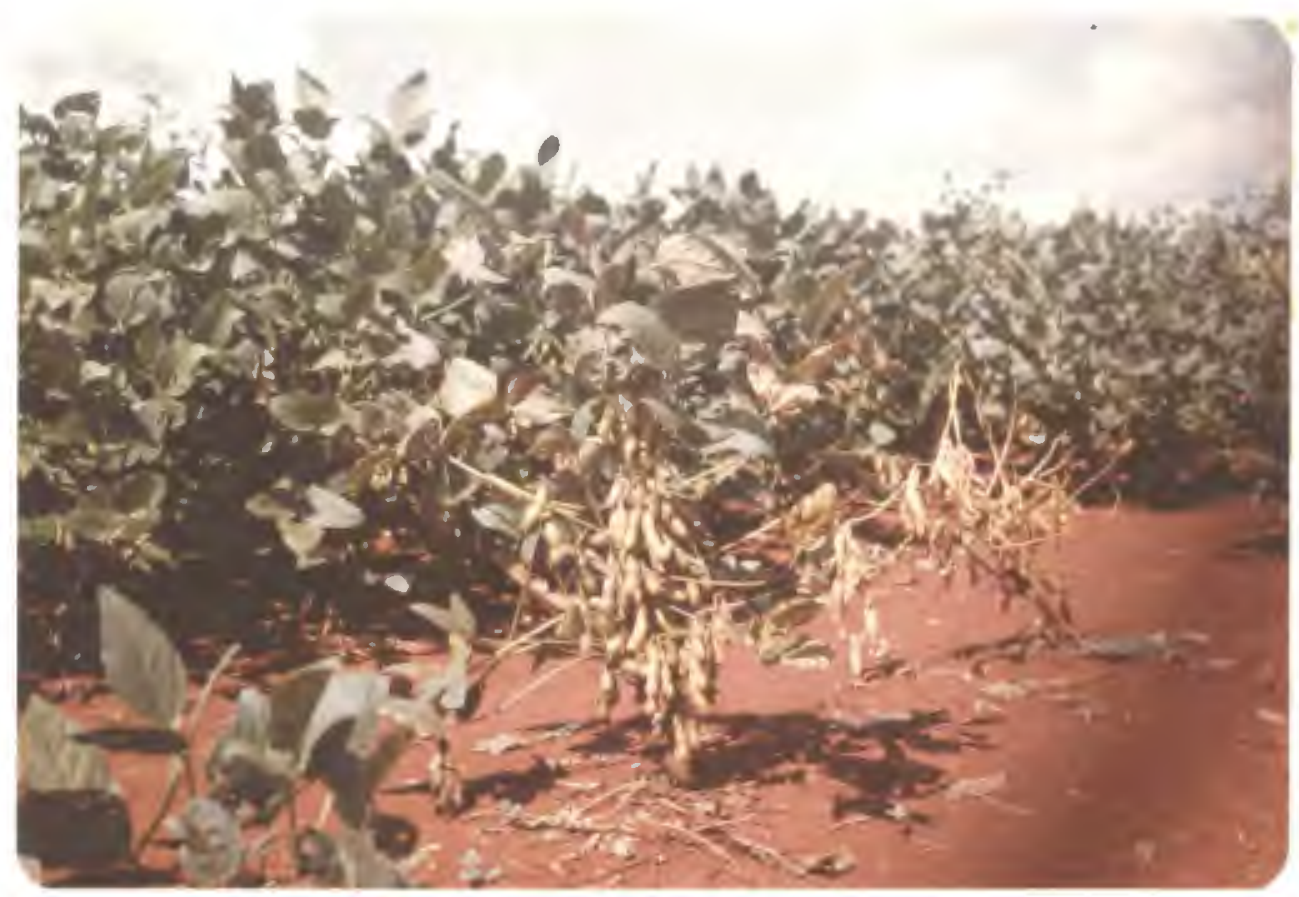

Foro 6. A soja em fase de maturação. 
21. A TRANSFORMAÇÃO NOS MEIOS DE ACESSO A TERRA

11.1 A reconcentração fundiária

A transformação em processo nos meios de acesso à terra e a rejconcentração fundiária são fenômenos que ocorrem de forma extensiva no Estado de São Paulo. Nesse aspectọ, entretanto, a região de Assis não segue os padrões do Estado na década de 1960 e sobrepuja suas taxas médias na primeira metade dos anos 1970, o que pode ser observado por uma comparação dos grupos de área do Estado e da MRH do As -. sis, como pode ser obsexvado na Tabela 1.34 abaixo:

TABEIA 1.34 - PORCENTAGEM DE PARTICIPAÇÃO POR GRUPOS DE AREA TOTAL NA MRH-ASSIS EM RELACÃO AO ESTADO, EM ANOS SELECIONADOS (ESTA$D O=100 \%$, AREAS EM HECTARES)

\begin{tabular}{lccccc} 
ANO & TOTAI & $>10$ & $10-100$ & $100+1000$ & $1000 \mathrm{e}+$ \\
\hline 1970 & 3.5 & 5.9 & 3.8 & 3.1 & 3.2 \\
1975 & 3.1 & 2.4 & 3.5 & 3.4 & 3.0 \\
1980 & 2.5 & 1.3 & 3.2 & 3.5 & 2.6 \\
\hline
\end{tabular}

FONTE: Calculado do Censo Agropecuário de São Paulo, IBGE, 1970.; Censo Agropecuário de S.Paulo, IBGE, 1975; Sinopse Preliminar do Censo Agropecuário de São Paulo, IBGE, 1980.

Embora tenha diminuido a participação da região na área total e na classe de estabelecimentos menores de 100 
hectares e maiores de 1000 hectares, ocorreu um aumento significativo na classe de área entre 100 hectares e menos de 1000 hectares.

o processo de concentração deu-se tanto pela tendência à reconcentração dos grupos de áreas menores de 100 hectares como pela redivisão de algumas propriedades de mais de 1000 hectares.

Analisando o comportamento dos grupos de área de lavoura entre 1970 e 1980 verifica-se um processo análogo. A participação das classes de área de 50 hectares e mais, apresentam um crescimento significativo. A classe entre 20 hec tares e menos de 50 hectares mantem-se estável, apresentando uma pequena expansão, enquanto as classes de área de me nos de 20 hectares sofrem um decréscimo bastante significati vo, como se pode observar na Tabela 1.35 abaixo:

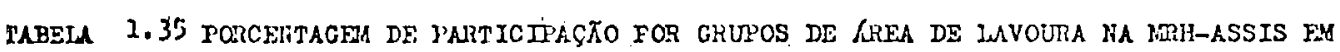
RELAÇXO AO ESTADO, FA ANOS SELECTOHADOS (RIFAS FTI HLCTARES, ESTADO= 100\%)

GR UPOS DE R R EA

\begin{tabular}{llllllllllllll}
\hline ANO TOThL & $\geq 1$ & $1-2$ & $2-5$ & $2-10$ & $20-20$ & $20-50$ & $50-100$ & $100-200$ & $200-500$ & $200-1000$ & $1000 e+$ \\
1970 & 3.4 & 0.8 & 1.7 & 2.9 & 4.0 & 4.4 & 4.0 & 2.7 & 2.4 & 2.4 & 1.9 & 2.0 \\
1975 & 3.0 & 1.2 & 1.6 & 2.2 & 2.4 & 3.8 & 4.3 & 4.7 & 4.5 & 5.5 & 2.7 & 3.9 \\
1980 & 2.5 & 0.4 & 0.9 & 2.5 & 1.9 & 3.1 & 4.3 & 4.6 & 5.0 & 6.4 & 3.8 & 2.2 \\
\hline
\end{tabular}


Esses dados demonstram o processo de reconcentração fundiária sendo feita basicamente à custa da propriedade de 20 hectares e menos, em favor da composição dos módulos fundiários compatíveis com o processo produtivo do "binômio soja-trigo" os quais promovem o máximo de concentração de áreas no grupo de 50 hectares e mais, basicamente triplicando a área das classes entre 100 hectares e menos de 500 hecta res. Este aspecto pode ser melhor analisado comparando os da dos agregados dos sete municípios maiores produtores de soja com o total do Estado, por grupo de área, como demons tra a Tabela 1.36 abaixo:

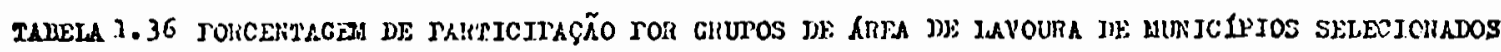

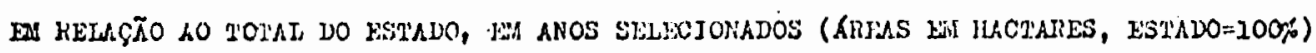

ORUTOS DE AREA

\begin{tabular}{|c|c|c|c|c|c|c|c|c|c|c|c|c|}
\hline ANO & TorAI & $\geq 2$ & $1 \vdash 2$ & $2+5$ & $2+30$ & $30+20$ & $20+50$ & $50+100$ & $100+200$ & $200+500$ & $200+1000$ & 100004 \\
\hline 1970 & 2.3 & 0.7 & 1.2 & 1.9 & 2.7 & 2.3 & 3.0 & 2.2 & 1.8 & 2.2 & 1.6 & 1.4 \\
\hline 2975 & 2.0 & 0.9 & 1.5 & 1.3 & 2.2 & 2.7 & 3.3 & 3.5 & 3.6 & 4.4 & 2.1 & 3.5 \\
\hline 1980 & 2.7 & 0.3 & 0.6 & 0.9 & 1.2 & 2.2 & 3.0 & 3.7 & 3.8 & 4.1 & 3.1 & 2.4 \\
\hline
\end{tabular}

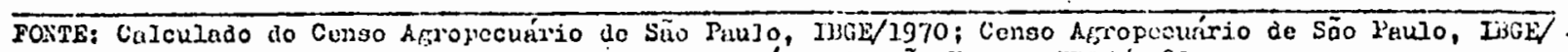

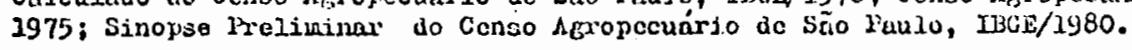


As grandes propriedades, de 1000 hectares e mais, apresentam um desmembramento fictício quando ligadas a agroindústria do açúcar e álcool. A formação de um certo número de estabelecimentos legalmente independentes administra dos via "holding" permite atuar nos preços da cana cortada, rebaixando os preços dos fornecedores e transferindo rendes para o setor industrial. (22)

Se a concentração da terra ocorreu de forma tão aguda, sendo mais expressiva no período de 1970 a 1975, o acesso à terra por parte das diversas categorias de trabalha dores e/ou exploradores na agricultura também sofreu trans formações, ainda mais agudas, restringindo-se o acesso à terra àqueles que tivessem antes acesso aos demais meios de produção socialmente determinados para a integração no"com plexo soja".

(22) "dado o fato de que a usina é a única na região, toda a produção que não está inserida no Complexo... sofre - problema da determinação dos preços da cana bruta.o artifício usado pelo complexo monopolístico foi a separação jurídica da fazenda (ou fazendas produtoras) em relação à Usina, transformando as primeiras em simples "vendedoras" ou fornecedoras de matéria-prima tal qual os demais proprietários. Com os capitais acumulados no setor industrial... o complexo tem condições de constantemente ampliar os meios de produção nas fazendas próprias produtoras, rebaixando continuamente os custos de produção da matéria-prima" c.f. Barriguelli, J.C, Conflito e Participação no Neio Rural: a greve da Usina Nova América (1962). Cadernos do C.E.R.U. no 12, Säo Paulo, setembro de 1979, p.15-16. 


\section{ocupado}

As transformações nas formas de arrendamento que assumem o caráter de aluguel da terra, pago em dinheiro, o desaparecimento quase completo àa figura do parceiro e do ocupante indicam os efeitos da transfornação no acesso à ter ra como consequência da integração da região. A relação dos grupos de estabelecimentos segundo a condição do produtior da MRH-Assis em relação ao Estado sofre uma queda generalizada sendo entretento, muito significativa em relação aos estabelecimentos de parceiros e ocupantes como pode ser observado na Tabela 1.37 abaixo:

TABETA 1.37PERCENTAGEM DE ESTABELECTMENTOS DA MRH DE ASSIS SEGUNDO A CONDIÇÃO DO PRODUTOR EMT RELAÇÃO AO ESTADO DE SÃO PAULO EH ANOS SELECIONADOS

C ONDIG

\begin{tabular}{|c|c|c|c|c|c|}
\hline ANO & TOTAI & PROPRIETARIO & ARRENDATARIO & PARCEIRO & OCUPANTE \\
\hline 1970 & 3.52 & 3.20 & 4.18 & 3.80 & 4.49 \\
\hline 1975 & 3.12 & 3.09 & 3.32 & 3.05 & 3.21 \\
\hline 1980 & 2.54 & 2.74 & 3.05 & 0.02 & 1.98 \\
\hline
\end{tabular}


En termos de composição regional, nota-se un aumento do número de estabelecimentos de proprietários que passam de 58\% em 1970 para 72\% em 1980 e uma diminuição dos outros grupos sendo que entre os estabelecimentos de parceiros ocorre uma queda, apresentando uma mudança de participação de $17 \%$ para $8 \%$ no mesmo período, como pode ser observado na Tabela 1.38 abaixo:

TABELA 1.38 PERCENTUAIS DE ESTABELECINENTOS DA MRHASSIS SEGUNDO A CONDIÇATO DO PRODUTOR EMI RELAÇÃO AO TOTAL DA REGIÃO EN ANOS SELECIO NADOS

$C O N D I C E O D O P R O D U T O R$

\begin{tabular}{lcccccc}
\hline ANO & TOTAL & PROPRIETARIO & ARRENDATAPIO & PARCEIRO & OCUPANTIT \\
\cline { 5 - 6 } & 1970 & 100.0 & 58.0 & 18.0 & 17.0 & 7.0 \\
1975 & 100.0 & 71.0 & 11.0 & 11.0 & 7.0 \\
1980 & 100.0 & 72.0 & 14.0 & 8.0 & 5.0 \\
\hline
\end{tabular}

FONTE: idem

Uma análise por área, tanto em relação ao Esta do como na composição interna da MRH-Assis demonstra mais claramente ainda, o grau de transformação nas formas de acesso à terra. $O$ grupo dos arrendatários é o único a sofrer a créscimo de importância em relação ao Estado, enquanto ainda uma vez o grupo dos parceiros apresentam as quedas mais significativas como pode ser examinado na Tabela 1.39. 
TABELA 1.39 PERCENTAGEM DE AREAS MRH-ASSIS SEGUNDO A CONDIÇÃO DO PRODUTOR EM REIAÇÃO AOS TO TAIS DO ESTADO, EM ANOS SELECIONADOS

C ON DI G $\tilde{A} O$ O D O $\quad P R O D U T O R$

\begin{tabular}{lccccc}
\hline ANO & TOTAI & PROPRIETARIO & ARREINATARIO & PARCEIRO & OCUPANTE \\
1970 & 3.14 & 2.98 & 3.44 & 3.79 & 4.09 \\
1975 & 3.11 & 3.06 & 4.14 & 3.21 & 2.76 \\
1980 & 3.05 & 2.98 & 4.07 & 1.98 & 3.37 \\
\hline
\end{tabular}

FONTE: idem

Em termos de composição regional fica demons trada a dominância quase absoluta das áreas cultivadas pelos próprios proprietários em relação às demais formas de acesso mantendo relativa importância o arrendamento, aछora sob no vas formas. Enquanto as áreas exploradas pelos próprios proprietários oscila entre $88 \%$ e 90\% no período entre 1970 e 1980 , as áreas sob arrendamento oscilam entre $6 \%$ a $8 \%$, caindo a área de parceria, de $3 \%$ para $1 \%$ e de ocupantes de $3 \%$ para $2 \%$, conforme Tabela 1.40 .

TAB. 1.40 PERCENTUAIS DE AREAS DA MRH-ASSIS SEGUNDO A CONDIÇÃO DO PRODUTOR EN RELACẼO AO TOTAL DA REGIÃO, EM ANOS SELECIONADOS

\begin{tabular}{lccccc}
\hline ANO TOTAL & PROPRIETARIO & ARRENDATARIO & $\frac{\text { PARCEIRO }}{2.0}$ & OCUPANTE \\
1970100.0 & 88.0 & 6.0 & 3.0 & 3.0 \\
1975100.0 & 90.0 & 6.0 & 2.0 & 2.0 \\
1980100.0 & 89.0 & 8.0 & 1.0 & 2.0 \\
\hline
\end{tabular}

FONTE: idem 


\subsection{Oacesso $\dot{a}$ terra}

4 análise dos mecanismos de acesso à terra co mo meio de produção a nível regional, se feita de forma abrangente, deveria levar em conta pelo menos três categorias de exploração: (a) o complexo agro-industrial açucareiro e alcoo leiro,(b) a produção integrada pelo binômio soja-trigo, e (c) um terceiro setor composto pela pecuária extensiva e pela agri culturarpecuária extensiva e _ cultura de alimentos, tendo em vista serem os mais expressivos.

0 grau de concorrência existente entre o " complexo-açucar" e o "complexo-soja" na competição pela terra em bora potencial, ainda não se expressou de forma significativa a ponto de merecer um destaque da análise. Numa conjuntura de preços internacionais em baixa para o açúcar, a tendência é o adia mento dos conflitos entre esses dois setores.

Do ponto de vista da oferta de trabalho os seto res referidos são complementares, atuando mais no sentido de manter os contingentes de trabalhadores na região (e com isso garantir uma ampla oferta de mão-de-obra), do que no sentido oposto, de concorrer no mercado, atuando em favor da alta dos salários.

Historicamente, o "complexo-açúcar" atuou como modernizador das relações de produção, promovendo a instala ção de núcleos de empresados permanentes, assalariados, primeiro 
em suas terras, depois em nucleos urbaṇos próximos, como por exemplo, Tarumã, no município de Assis. Teve portanto, o papel de garantir as bases para a liberação da mão-de-obra catị va nas demais categorias de estabelecimentos produtores.

A Iiberação e a utilização sazonal e complementar de parte da força-de-trabalho regional, pelo "complexo-so ja". representa por outro lado a ampliação e manutenção dessa reserva, da qual poderá dịspor nos momentos de "pico" de tra balho e em suas expansões.

Desde que se defina na região um sistema Indus trial baseado na energocultura dentro de um quadro de crise energética, a concorrência pela terra poderá agudizar-se, e na dependência das formas concretas de composição dos meios de produção no "binômio soja-trigo", este ultimo poderá ser afetado.

Um aspecto que merece destaque em relação ao comportamento desses dois setores diz respeito ao desequilí brio ecológico causado pelo advento da produção da soja e do trigo nas proximidades das áreas de cana que propiciou o aume to da população de pombas "amargosas" na região de Assis e na área vizinha do Paraná.

Os processos produtivos adotados na agro-industria açucareira começaram por destruir predadores naturais deg sa espécie (principalmente cobras e lagartos) pela "queima de canaviais que antecede os cortes, os quais se tornaram áreas privilegiadas de reprodução da espécie, a qual encontra ali mentação farta nos campos próximos de trigo ou soja, comendo 
as sementes de trigo e as plântulas na fase de germinação da soja. O fenômeno tem se apresentado agudo a ponto das quebras de safra, já estarem repercutindo economicamente em alguns municípios. Tendo em vista que o "complexo-açucar", onde se inicia a cadeia reprodutiva não é afetado, não há expectativa de mudanças em seus processos produtivos tendo em vista a eliminação do problema, que se coloca claramente para o "complexo-soja" no momento mesmo em que ocorre sua consolidação econômica na área.

Quanto ao setor pecuário e agricultura de ali mentos, foram expulsos para a periferia das áreas integradas a "complexo-soja" ocorrendo transformações significativas, tanto pela elevação de seu padrão técnico, como pela recomposição das categorias do pessoal ocupado e-modernização das re lações de produção como já foi demonstrado.

Dois aspectos merecem entretanto ser destacados ou seja, (a) as formas de acesso à terra como meio de produção nas áreas integradas pelo binômio "soja-trigo" e (b) a emergência da pequena propriedade familiar capitalizada.

A redefinição das formas tradicionais de acesso à terra tem se verificado por uma depuração das formas de par ticipação na produção que define de forma clara, de um lado a emergência de um segmento detentor de meios de produção e capaz de movê-los de forma ampliada e de outro a definição de um segmento desde há muito expropriado de meios, mas que ainde reproduzia-se graças a diversos mecanismos de acesso à terra com pagamento não monetário. 
E o caso dos parceiros, que pagam o acesso com trabalho e do arrendatário tradicional que paga o acesso em produto (existindo entre estas, formas mistas e combinadas), agora convertidos em assalariados permanentes ou temporários.

A participação destes na produção se dá na qualidade de vendedores de força de trabalho e na remuneração mo netária. Uma das características marcantes é a transferência física desse contingente para fora da terra, o que redefine seu universo de possibilidades e determina as novas condições de reprodução.

Junto com eles, vem também o "colono" e "camara da", figuras que se completam na organização familiar de pro dução dos trabalhadores sem terra.

0 acesso à terra como meio de produção se faz agora, cada vez mais intensamente, pela detenção ou acesso a outros meios de produção socialmente determinados.

A definição de novos padrões técnicos de produ ção e o caráter integrado de produção, por um lado, fez da terra, cada vez mais, um meịo muito embora indispensável, não suficiente para a produção. A propriedade privada da terra não é em si mesma um elemento garantidor das possibilida des de integração aos novos sistemas produtivoso os demaịs meios (capital) é que definem a possibilidade de integração.

o processo de integração, posto em marcha, destruiu rapidamente as bases de sustentação da organização da 
produção em moldes tradicionais de forma que a propria reprodução do proprietário passa pelo crivo da capitalização. Não só se restringem as formas de acesso à terra como se restrin gem e se redefinem tendencialmente as formas de produção.

Impossibilitades de se integrar aos novos padrões produtivos, muitos pequenos proprietários descapitaliza dos deixam de produzir, alugam a terra e transformam-se em simples rentistas. Por outro lado, segmentos sociais capitali zados quase sempre proprietários, arrendam essas terras e se integram no sistema dentro dos modelos fundiários adequados à sua reprodução ampliada.

0 meio por excelência, de acesso a terra tornase então o capital-dinheiro que imediatamente deve ser conver tido em capital produto (maquinárias, insumos, aluguel de for ça de trabalho) e em muitos casos, aluguel da terra.

0 arrendamento em dinheiro, que se configura no aluguei da terra esta ligado muito mais às necessidades de produzir dertro dos modelos fundiários adequados ao sistema de máquinas e ao piso de produtividade determinado, do que ao engajamento de segmentos não tradicionais ao setor. 0 que se observa é uma expansão relativa do proprietário cọo produtor em detrimento de outras categorias.

O processo de consolidação desse sistema produtivo foi feito de forma induzida, de fora, pela ação dirigida do Estado e do sistema financeiro, que juntos atuaram no sentido de capitalizar a agricultura com a criação de um sistema 
creditício com juros reais negativos aceitando como garantiaa hipoteca das terras e a penhora da colheita, como se viu.

Esse sistema favorece a capitalização tanto da grande como da pequena propriedade, em determinadas circunstâncias. A pecuária apresenta novos padrões técnicos, o esta belecimento integrado no "complexo-soja" amplia-se e se conso lida, motoriza-se a pequena propriedade organizada na base fa miliar da produção e esta também consolida-se pelo incremento de produtividade.

Em todas as categorias dominam os proprietários como exploradores diretos, privilegiados em relação ao acesso ao capital dinheiro, via modalidades creditícias vigentes.

A política creditícia acába gerando um círculo vicioso dentro do qual só têm acesso à terra, como meio de pró dução, aqueles que têm acesso aos demais e principais meios de produção (sistema de máquinas, insumos industrializados) e força de trabalho. Por outro lado, só têm acesso a esses meios aqueles que detêm a propriedade ca terra.

Eis porque, muito embora a adoção do "binômio soja-trigo" corra dentro de uma conjuntura momentâneamente fa vorável, com um peso aleatório elevado, sua consolidação só foi possível pela ação direta do Estado articulando a produ ção regional a.o sistema financeiro e por extensão ao complexo agro-industrial altamente subsidiado.

A ação do Estado promove o estreitamento dos ca nais de acesso à terra e dirige por diversos meios a integração ao mercado intermacional. 


\section{A URBANIZACẼO DOS TRABATHADORES}

A liberação da mão de obra cativa deu-se de forma que, a "terra livre" para o trabalhador sem terra se apre sentasse como sendo a cidade, Iugar e momento da "liberdade" de seu trabalho.

Em pouco tempo as "águas" ( 23 ) foram despovoadas. Irabalhadores e proprietários, todos migraram. E a terra também ficou "livre" para organizar-se em novos moldes.

Os vales antes apresentavam um "habitat" em forma de rosário, com o casario disposto ao longo do ribeiräo, co roando as testadas das pequenas propriedades. Hoje são quase desertos.

Os pequenos núcleos e as periferias urbanas ab sorveram como puderam esses contingentes recém-chegados. Depen dendo da localização em relação às novas oportunidades de trabalho e as vias de acesso, alguns núcleos foram sendo defini dos como áreas preferenciais de residência dos volantes, en quanto outros núcleos foram se extinguindo.

Nesse processo, go sul do município de Assis, ex-

(23) "águas" são denominações locais aos vales hoje povoados e tradicionalmente difinidos como glebas, pelo costume de definir os limites das terras pelas cumeadas. Esse costume reflete a "tradição hidráulica" mineira, adquirida nos trabalhos de mineração e os aproveitamentos míl tiplos da água como fontede alimentaçäo ie força motriz. 


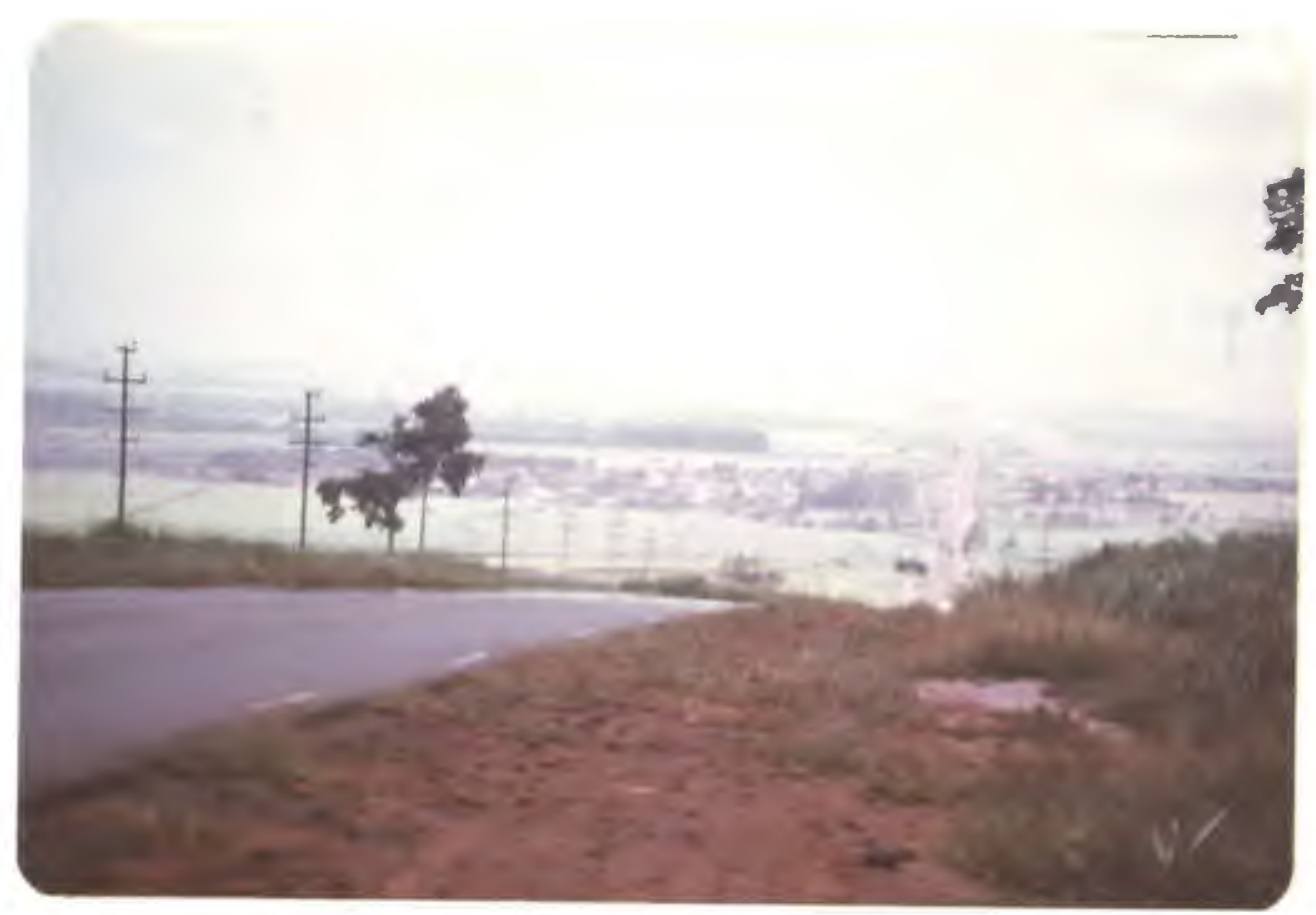

FOTO 13. Vista Ianorâmica de Tarưnã

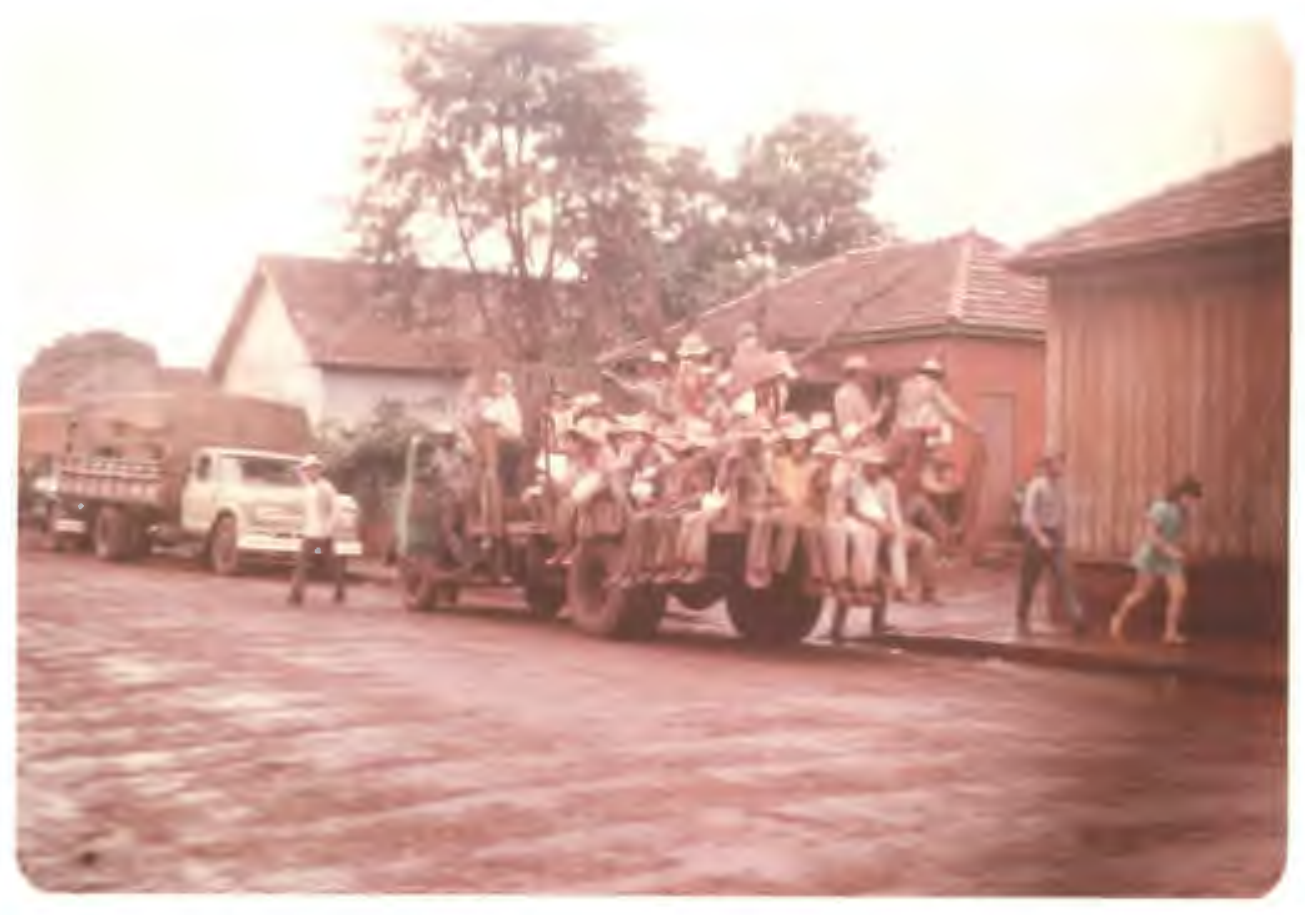

FOTO 14. Trabalhadores voltanảo do corte de cana - Tarumã 
tinguem-se o bairro dos Gatetos e o núcleo do Dourado e cresce Tarumã, junto à SP-333.

Esse núcleo, teve origem em uma "venda" de beira de estrada e seu crescimento foi lento a princípio, adquirindo expressão em meados de 1960, como mostra a Tabela 1.4.1.

TABELA 1.41 - EVOLUÇÃO PERCENTUAL DA POPULAÇÃO RURAL E URBANA DE TARUMA NAS DATAS DOS CENSOS $(1980=100)$

$\begin{array}{lrrrr} & \frac{1950}{96.0} & \frac{1960}{235.0} & \frac{1970}{184.0} & \frac{1980}{100.0} \\ \text { RURAL } & 96.0 & 7.0 & 50.0 & 100.0 \\ \text { URBANA } & 5.0 & 7.0\end{array}$

FONTE: Censo Demográfico do Estado de São Paulo, IBGE 1950 a 1980.

Em 1962 contava com cerca de 80 edificações (ver Cartograma 1). Abrigava sitiantes, trabalhadores rurais sem terra, assalariados da usina Nova América (complexo-açucareiro) e pessoal ligado ao setor urbano.

Bm 1972 já contava com cerca de 420 edificações resultado do processo de liberação de mão de obra cativa, pela integração da região ao "complexo-soja"e pela substituição do cultivo de algodão.

Os trabalhos de campo efetuados em 1976 e 1978 
de forma bastante sistemática possibilitaram a execução de "cortes" no processo eaobservaráa dois momentos da urbanização, que embora muito próximos puderam exibir transformações。

Em 1976 os trabalhos sistemáticos envolveram a aplicação de um inquérito domiciliar em um sorteio de $20 \%$ dos domicílios levantados por caminhamento. Permitiu ainda a construção de uma planta funcional, que repetida em 1978 pode docu mentar mudanças sensíveis no processo de urbanização.

Nota-se que o desenvolvimento do núcleo caracterizou-se (a) pela sua expansão em área, com a abertura de no vos loteamentos e adensamento pela construção de moradias e (b) pela concentração de funções urbanas antes quase inexisten tes, tanto institucionais (escola, posto de saúde, sub-prefeitura...) como atividades privadas com a expansão e a modernizâ ção concomitante do setor terciário. Armazéns de fornecimento são transformados em supermercados, aparecem as agências bancá rias, etc..

A partir de 1962 a expansão "salta" para além da estrada o ocorre um adensamento em todo núcleo inicial. Novas levas de "volantes" se instalam em loteamentos periféricos como pode ser observado nos Cartogramas 2 e 3.

Foram examinadąs várias características do nú cleo, tendo em vista avaliar as condições de vida que poderiam oferecer^a perenidade com que se constrói esse espaço urbano. 


\subsection{Una perfil do núcleo de Tarumã}

0 material de construção é a madeira (taboas de peroba) com construções em quatro águas, duas águas e urna água num total de $47 \%$ das habitações.

Em 1976 as casas de madeira usada representavam $11 \%$ do total das habitações, tendo passado a $29 \%$ em 1978. Este fenômeno se explica pela "migração" da casa.

No processo de liberação da mão de obra cativa, os proprietários, dependendo do tipo de ligação que tinham com os trabalhadores celebram vários tipos de acordos tendo em vis ta a instalação do trabalhador fora da propriedade; um desses $\underline{a}$ cordos é a cessäo da moradia que é desmontada na propriedade e montada em um terreno urbano. Essa cessão pode ser feita por doação ou por venda do material. En geral o trabalhador domina a arte da carpintaria de forma que ele mesmo com sua famíliase encarrega do processo de transferência. Há muitos casos em que além de casa foi doado um terreno em Tarumã e outros casos em que há apenas uma cessão da habitação e do terreno.

Mritos sitiantes também transferiram moradias pa ra o núcleo. Nesse processo, dependendo de suas possibilidades constrói uma casa nova e monta a antiga casa do sítio para alu guel ou para outra pessoa da família. No período em que foram feitos trabalhos de campo, o preço da terra urbana era acessível a uma grande parte de moradores que procuravam o núcleo.No processo de crescimento, o núcleo inicial foi valorizado de 
forma a concentrar as habitações mais modestas dos "volantes" na periferia do núcleo inicial e para além da estrada de rodagem.

Cerca de 54,0\% dos proprietários de casa alugada moravam em Tarumã e 29\% moravam ao lado do imóvel alugado, o que demonstra que o aluguel. não define um tipo de rentista nem um tipo de exploração, mas a possibilidade de uma renda a mais para famílias "volantes" ou sitiantes pela propriedade fortuí ta de um terreno maior e da possibilidade de realizar mais uma construção. Demonstra também a inexisteñcia de segregação en tre esses dois grupos de trabalhadores, que ainda convivem, em nível super-estrutural, dentro das relações de parceria a pouco destruídas.

A forma dominante de acesso à moradia é pela a quisição. Em 1976, correspondia a 60\% das habitações das quais 57,5\% foram declaradas como pagas, aparecendo em segundo lugar o aluguel $(32,5 \%)$ e a cessão $(6,3 \%)$.

Cerca de 51\% das habitações pagavam o aluguel em até dois dias de trabalho e $81,8 \%$ com até quatro dias de traba Iho, tendo por base o preço do dia de trabalho do volante.

Com a dificuldade de aquisição de madeira na região, tendo em vista que se esgotaram as matas em exploração, começaram a aparecer as habitações de alvenaria, inclusive blo cos de cimento; que embora feito de material construtivo não encontrado na região, ainda é acessível. 
0 número de habitações improvisadas como casas de coqueiro de um único cômodo ou abrigos cujas paredes fo ram completadas com pedaços de "encerado" ou sacos de plásti cos utilizados na embalagem de fertilizantes, também é muito frequente. Fin 1976, cerca de 14\% das habitações da amostra e ram desse tipo. Uma descrição das habitações segundo o material aplicada pode ser examinado na Tabela 1.42 abaixo:

TAB. 1.42

MATERIAIS DE CONSTRUÇÃO DE HABITAÇÕES EM TARUMÃ EM 1976

MADEIRA NOVA

MADEIRA USADA

ALVENARIA APARENTE

ALVENARIA REVESTIDA

COQUEIRO

BARRACO
$36 \%$

$11 \%$

$25 \%$

$11 \%$

$3 \%$

$14 \%$

Quanto ao crescimento do núcleo constata-se que $48,2 \%$ das habitações tem quatro anos e menos, tendo sido insta ladas entre 1972 e 1976 e que 87,5\% tinha 10 anos e menos, isto é, Tarumã cresceu oito vezes entre 1966 e 1976.

Apresentando uma idade média da habitação: de seis anos. O número médio de pessoas por habitação é de cin 


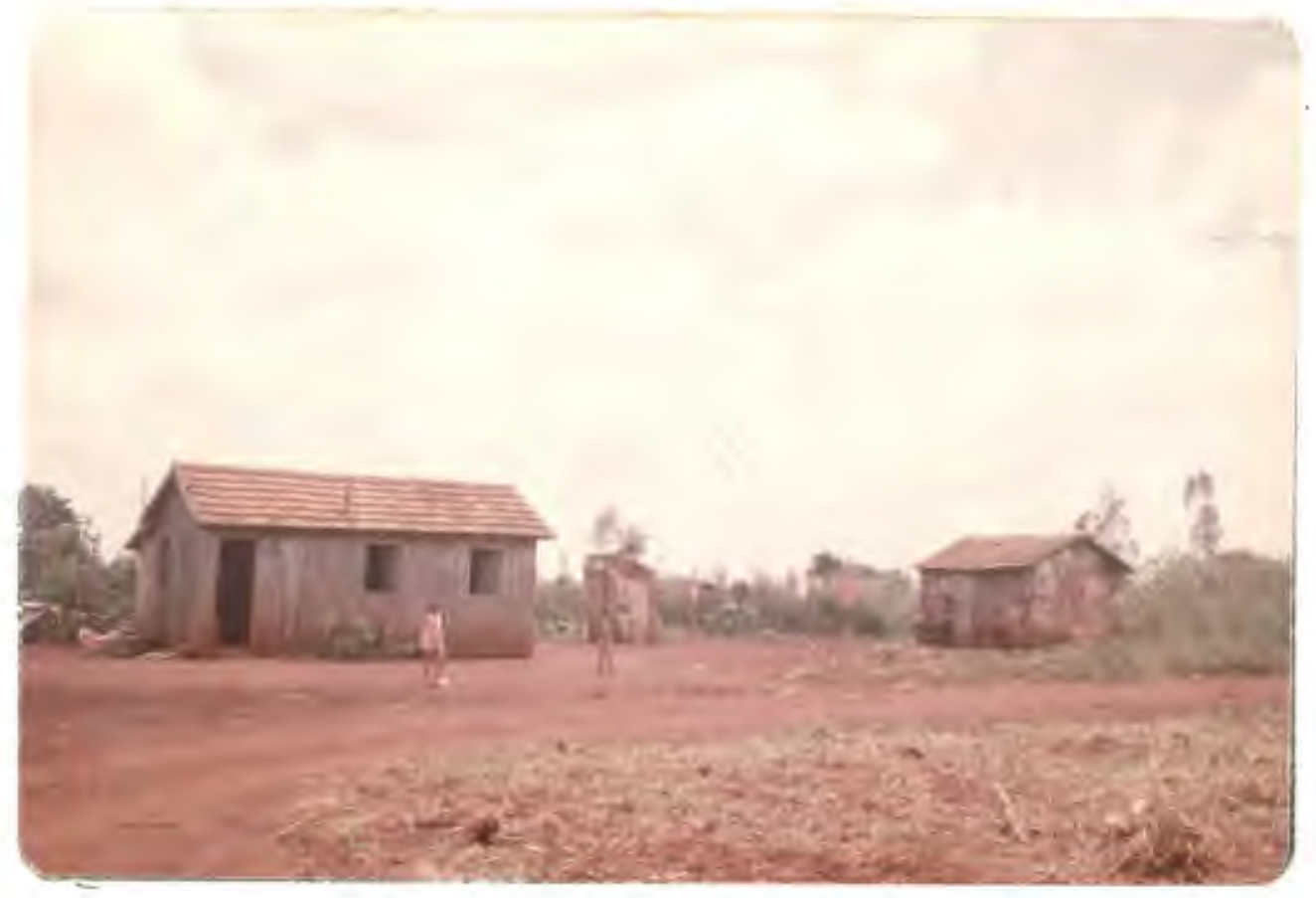

Foto. 15. Habìucucão " "Volantes" onde vale o Improviso. Taruma

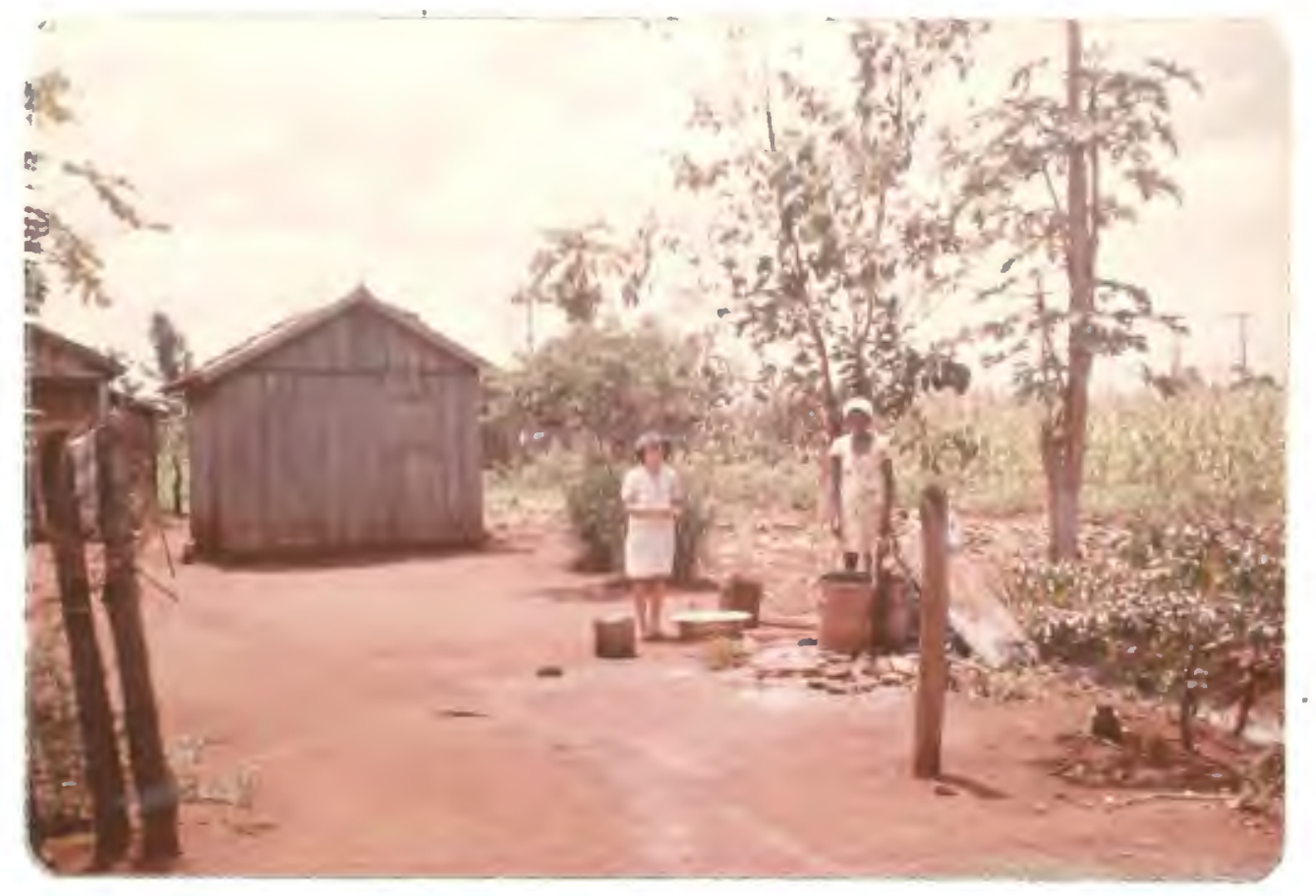

Foto 16. Pequeno rultivo de Sorgo juinto à
casa para confecça de!vassoutas. 


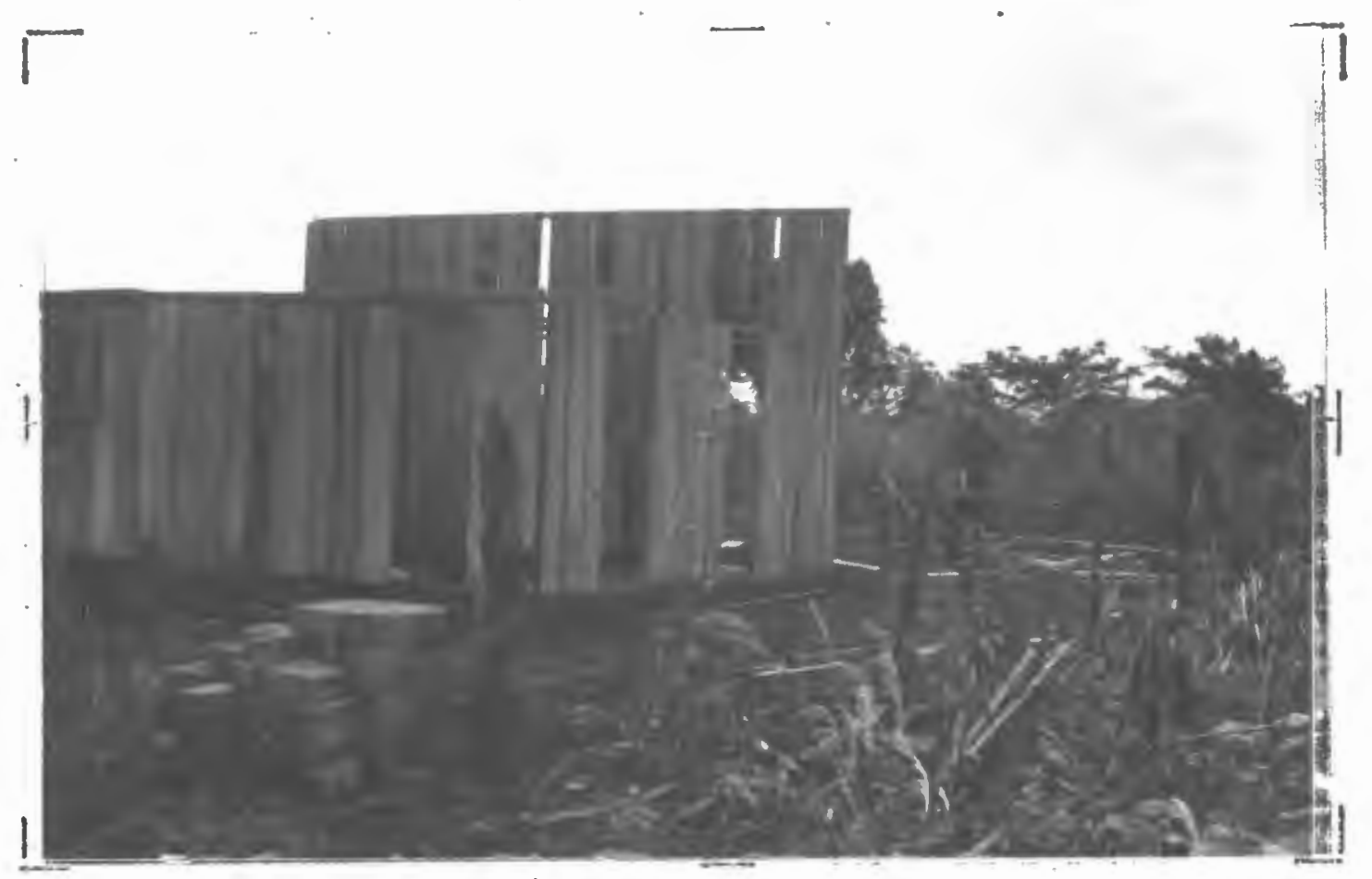

FOTO 17. C "Seu" Antorio constroi a sua casa, Tarumã.

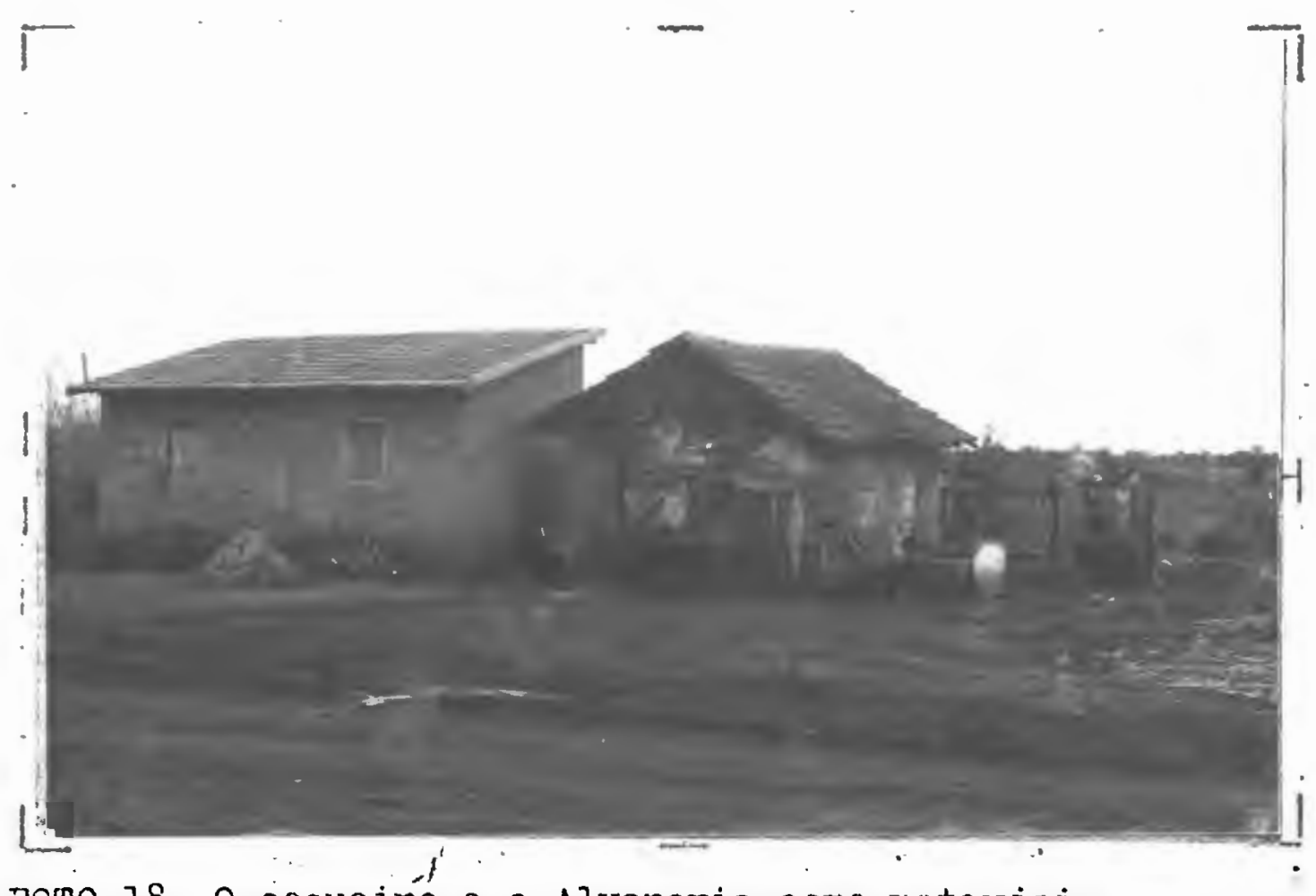

FCTC 18. O coqueiró e a Alvenaria como materiais de construção - Tamuãa. 


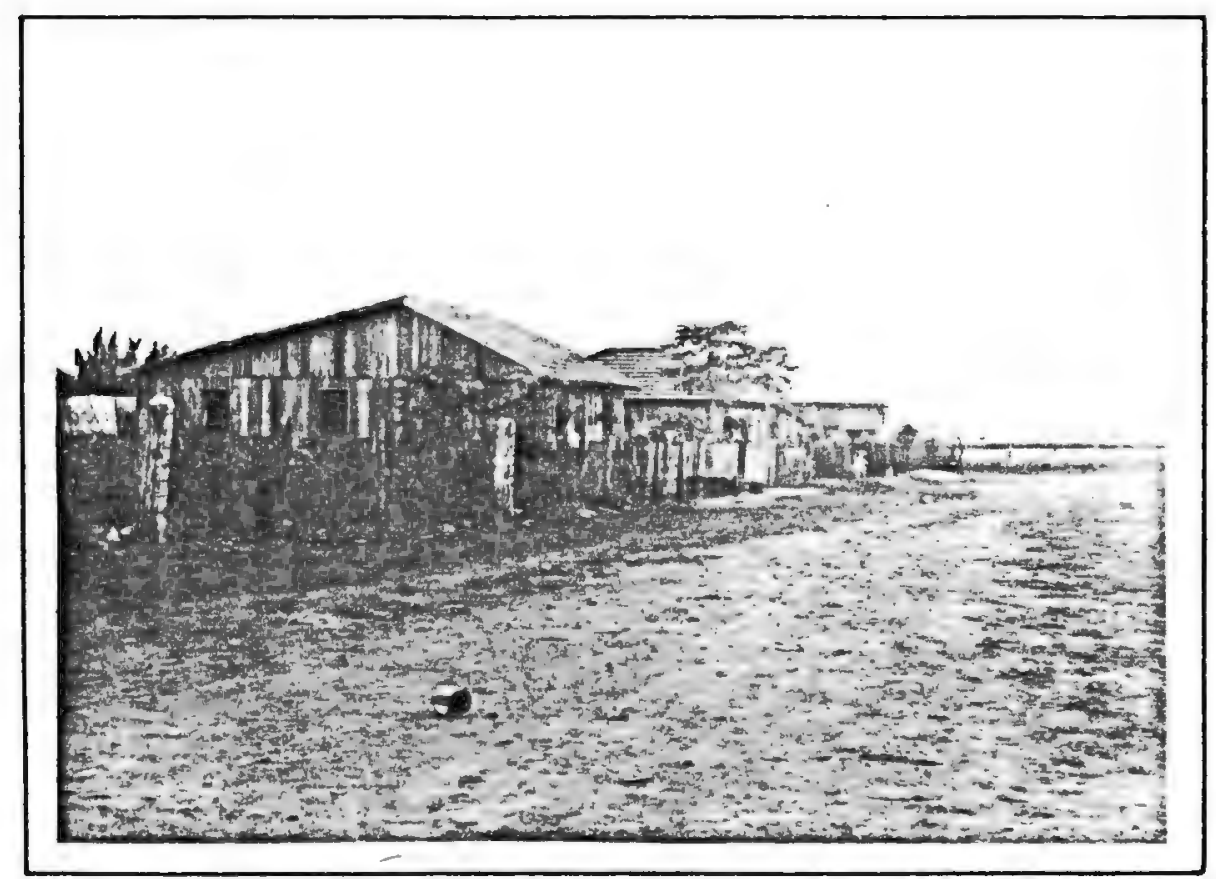

FOTO 19. A Habitação também migra casa construida com madeira usada - Candido llota

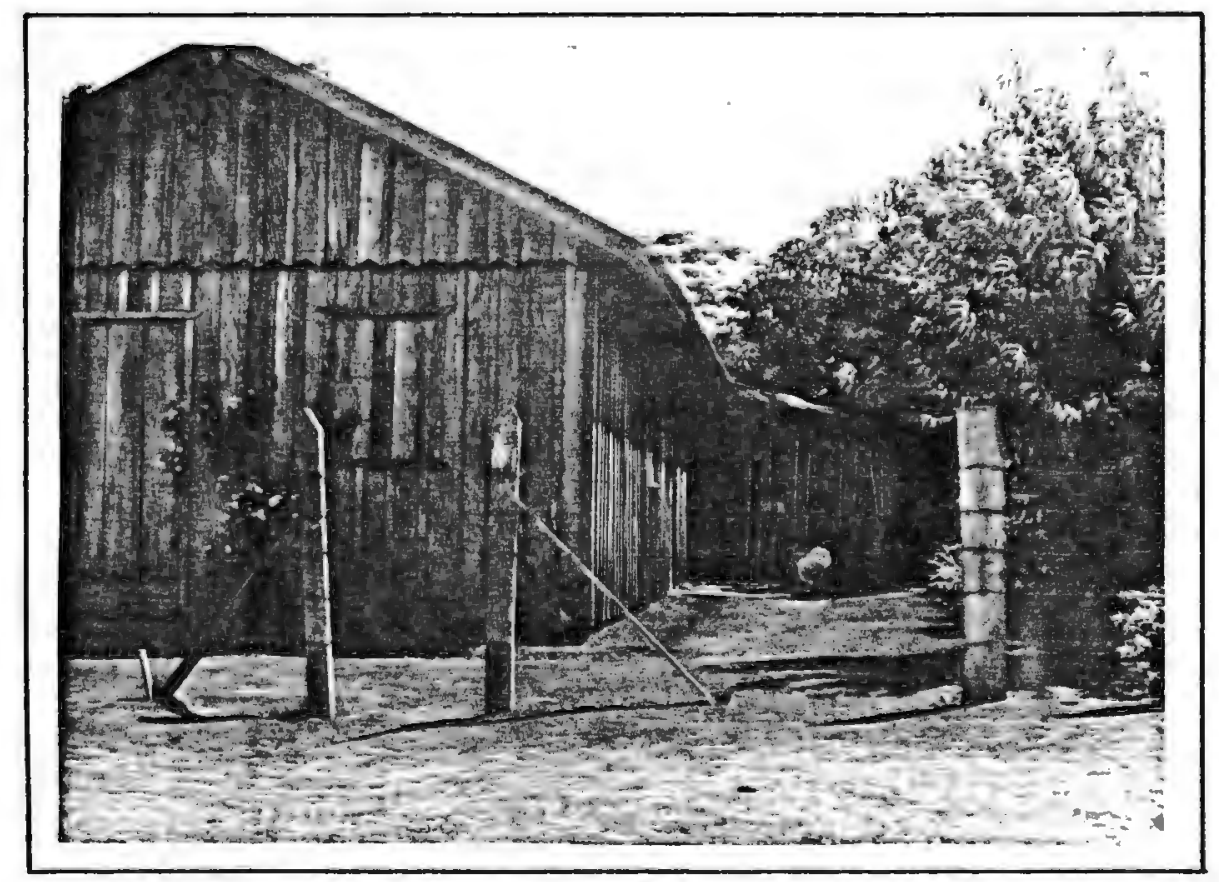

FOTO 20. Casa de madeira usada Note-se o detalhe das emendas para reaproveitamento das tabuas 


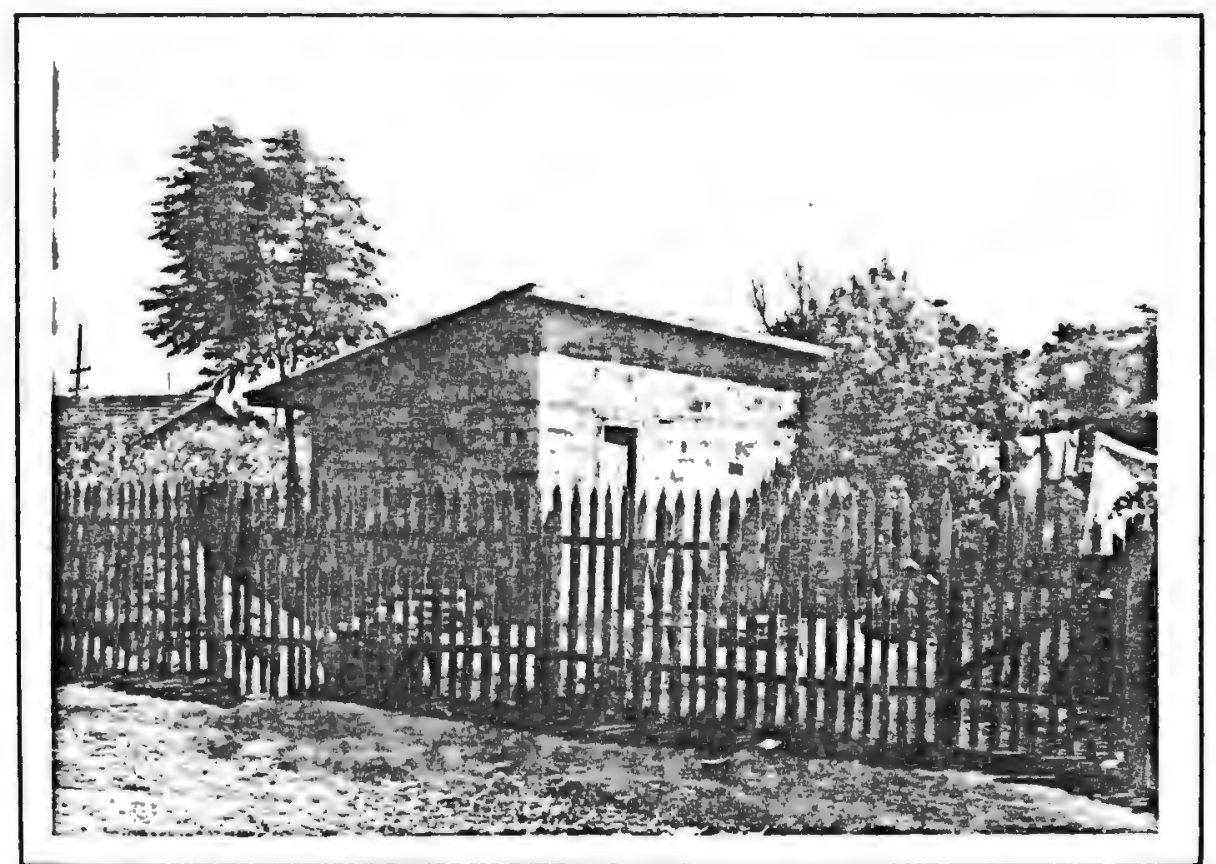

FOTO 21. A madeira já é material raro. Utilização de blocos de concreto na construção.

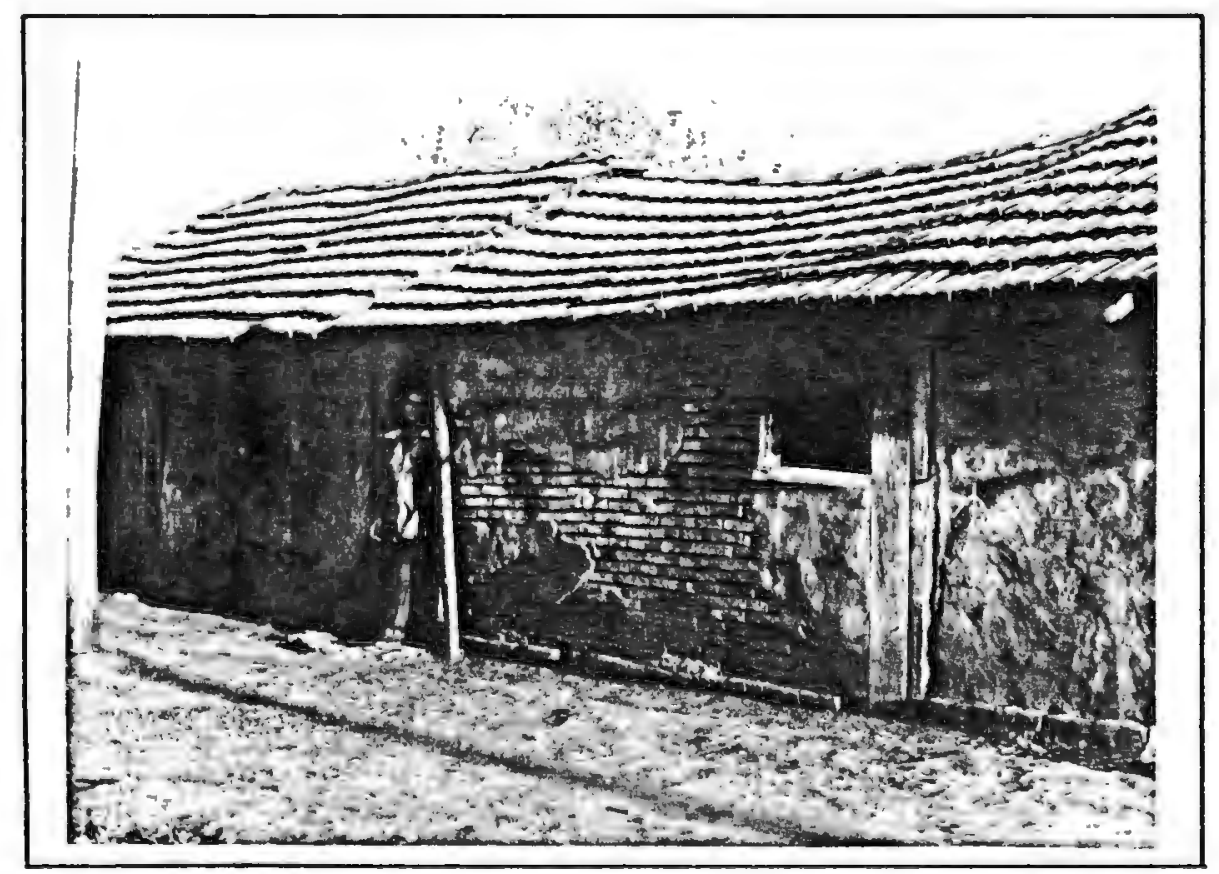

FOTO 22. Mesmo as habitações abandonadas são úteis - Município de Candido Kota 
co pessoas (sendo a mediana igual a quatro)。

$$
\text { TABELA } 1.43 \text { - ACESSO A MORADIA - TARUMẼ - } 1976
$$

CAFEGORIA

- Alugada

- Própria/paga

- Em aquisição

- Cedida

$$
\begin{gathered}
\% \\
32.5 \\
57.5 \\
3.8 \\
6.3
\end{gathered}
$$

Quanto ao nível da edificação e da construção, $35 \%$ são bem conservadas, 50\% pouco conservadas e $15 \%$ sem qualquer conservação.

A utilização da habitação é feita para fins ex clusivamente residenciais em 99\% dos casos, apresentando em média entre quatro e cinco cômodos, sendo que $86 \%$ das habita ções apresentavam três cômodos e mais.

O padrão urbano até 1976 tinha como indicadores a existência de $54 \%$ das habitações abastecidas de energia elétrica, 61\% com água encanada e $61 \%$ com instalação de fossas(en tre sépticas e negras).

A definição funcional de Tarumã deu-se não só pela modernização de seu setor terciário como pela definição de um centro comercial e de serviços que corresponde a àrea ocupa da por volta de 1962 e a segregação das áreas destinadas prefé rencialmente à residência na periferia desse núcleo central. 
Em 1978 já foi possível constatar a existência de áreas onde dominavam as habitações precárias, áreas prefe renciais de residência de volentes, indicadores da agudização da crise de trabalho.

Até 1978 Tarumã apresentava um bom padrão, muito acima dos padrões das periferias urbanas de Cândido Mota, Pla tina e Palmital, pelos serviços oferecidos.

Im face de sua situação estratégica em relação aos diversos mercados de trabalho (cana-de-açúcar, algodão no norte do Paraná e sojal, a sazonalidade do trabalho é menor que nos demais núcleos e a população tende a ser mais estável.

Entrevistas realizadas en 1976 e 1978 permitiram registrar uma tendência à formalização das relações de traba Iho acusada pelo aumento de trabalhadores com carteira de trabalho e benefícios sociais.

A existência de campos de preparação de mudas ("cana-semente") junto ao núcleo onde os cuidados de manejo são maiores e o trabalho não se interrompe, propicia mais uma oportunidade de trabalho permanente, muito embora a nível de salário mínimo urbano.

Nos demais núcleos, os meses de penúria são mais extendidos e por isso mesmo a população é menos estável no núcleo, usando ainda expedientes de manutençäo da família pelo cultivo de hortas domésticas. 
Essa prática foi generalizada em Tarumã até 1976 onde se observava também a plantação de vassoura $(24)$ em ter renos não ocupados tendo por objetivo a obtenção de um ganho adicional pelo trabalho artesanal.

Em 1978 essas plantações haviam quase desapareci do, bem como as hortas domésticas, pois o espaço disponívei ha via sido tomado por novas construções.

(24) espécie de sorgo utilizado na alimentação de animais, cụ ja "bandeira" formada de hastes lenhosas, são utilizadas na fabricação de vassouras domésticas. 

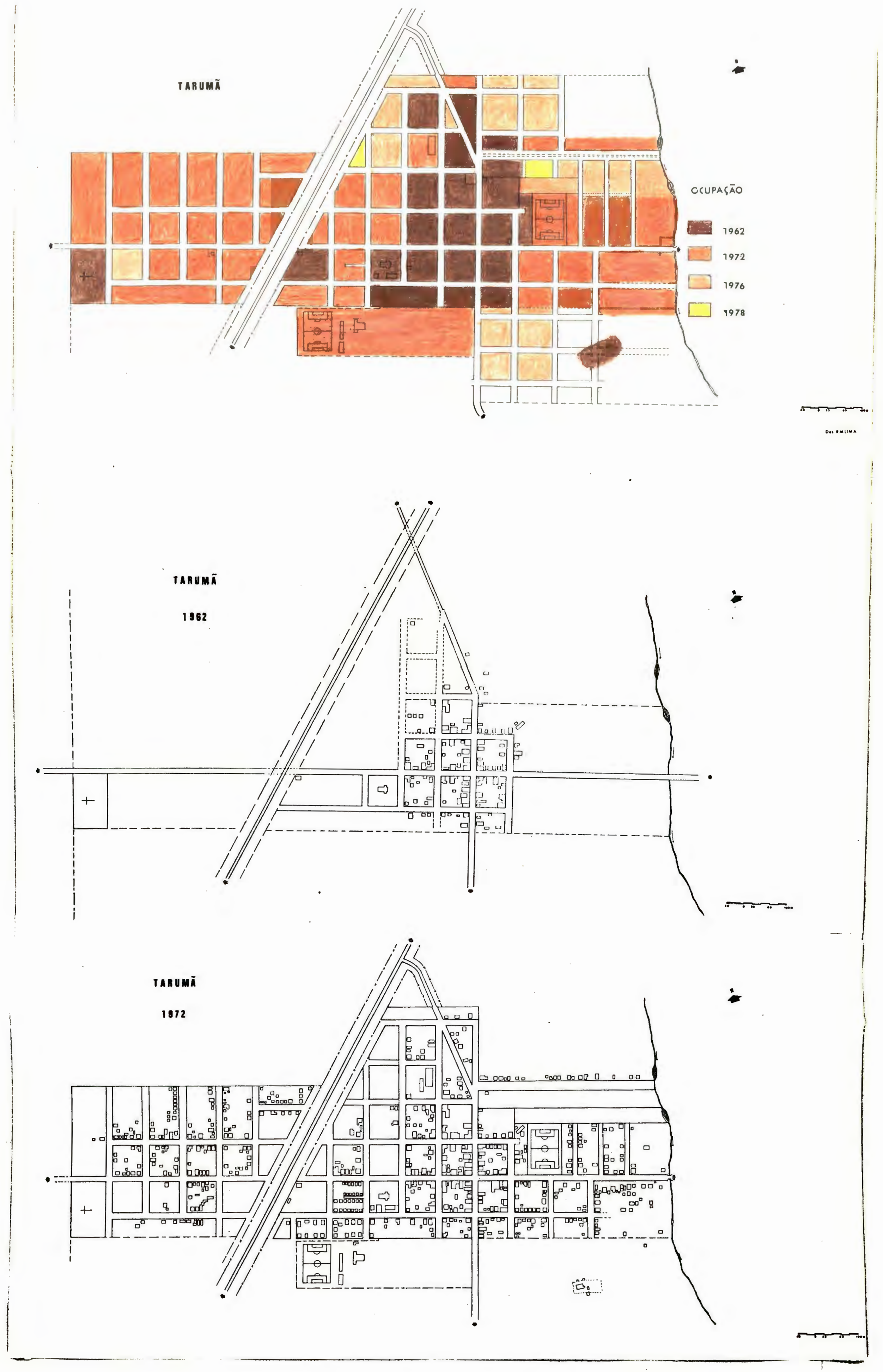


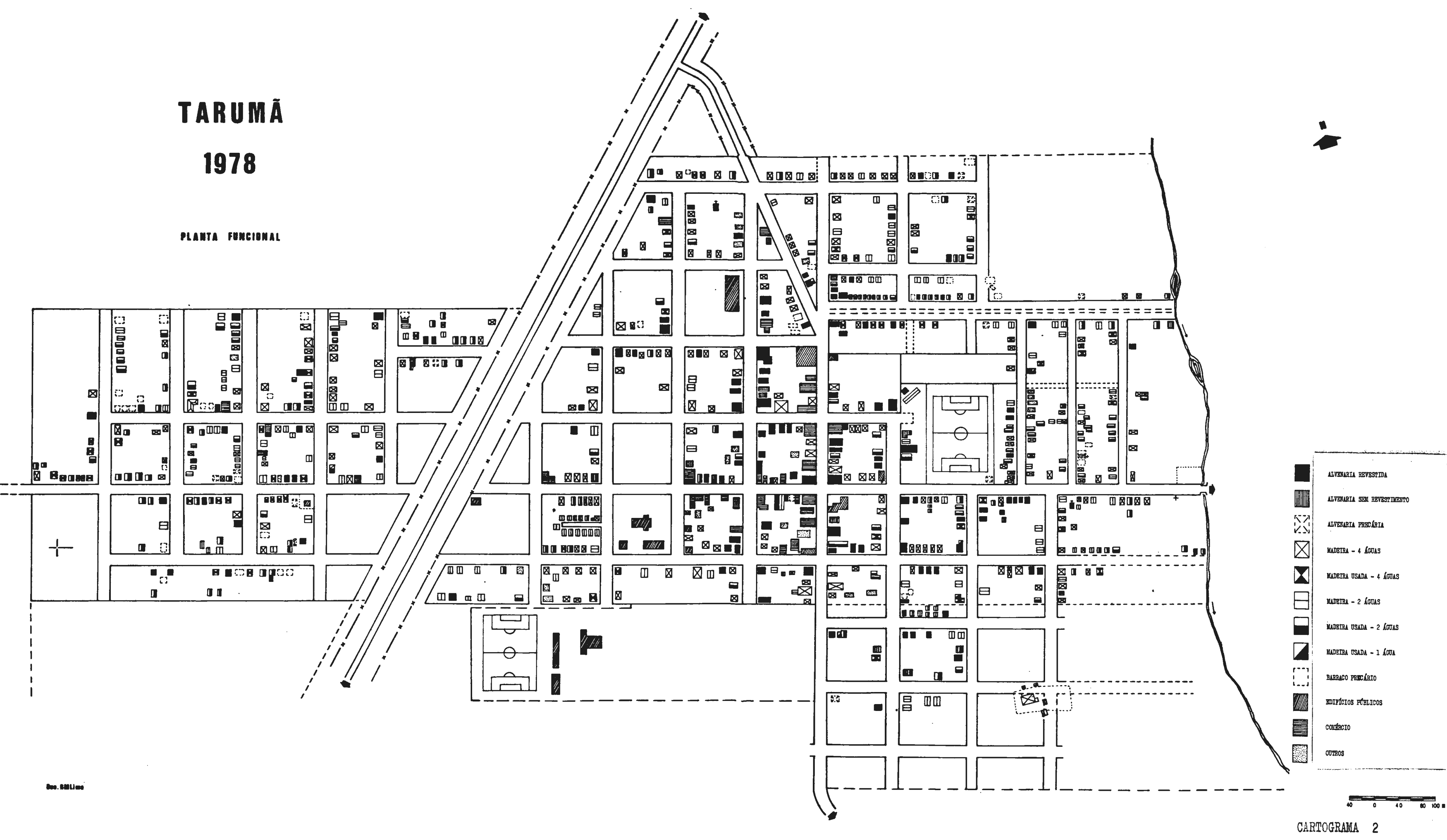




\section{TARUMÃ}

\section{8}

EXPANSÃO DO NÚMERO DE CASAS DE MADEIRA ENTRE 1976 - 1978

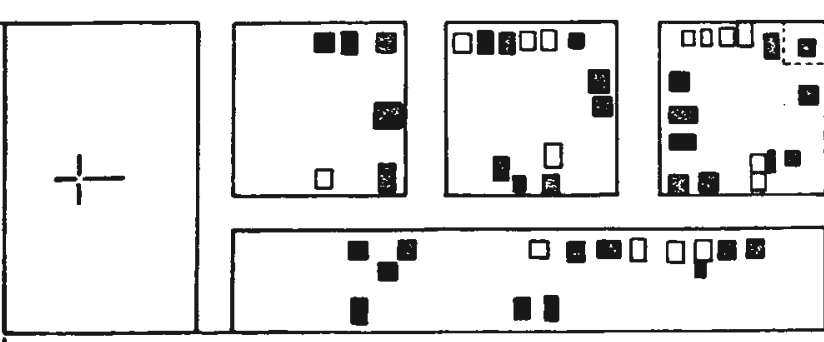

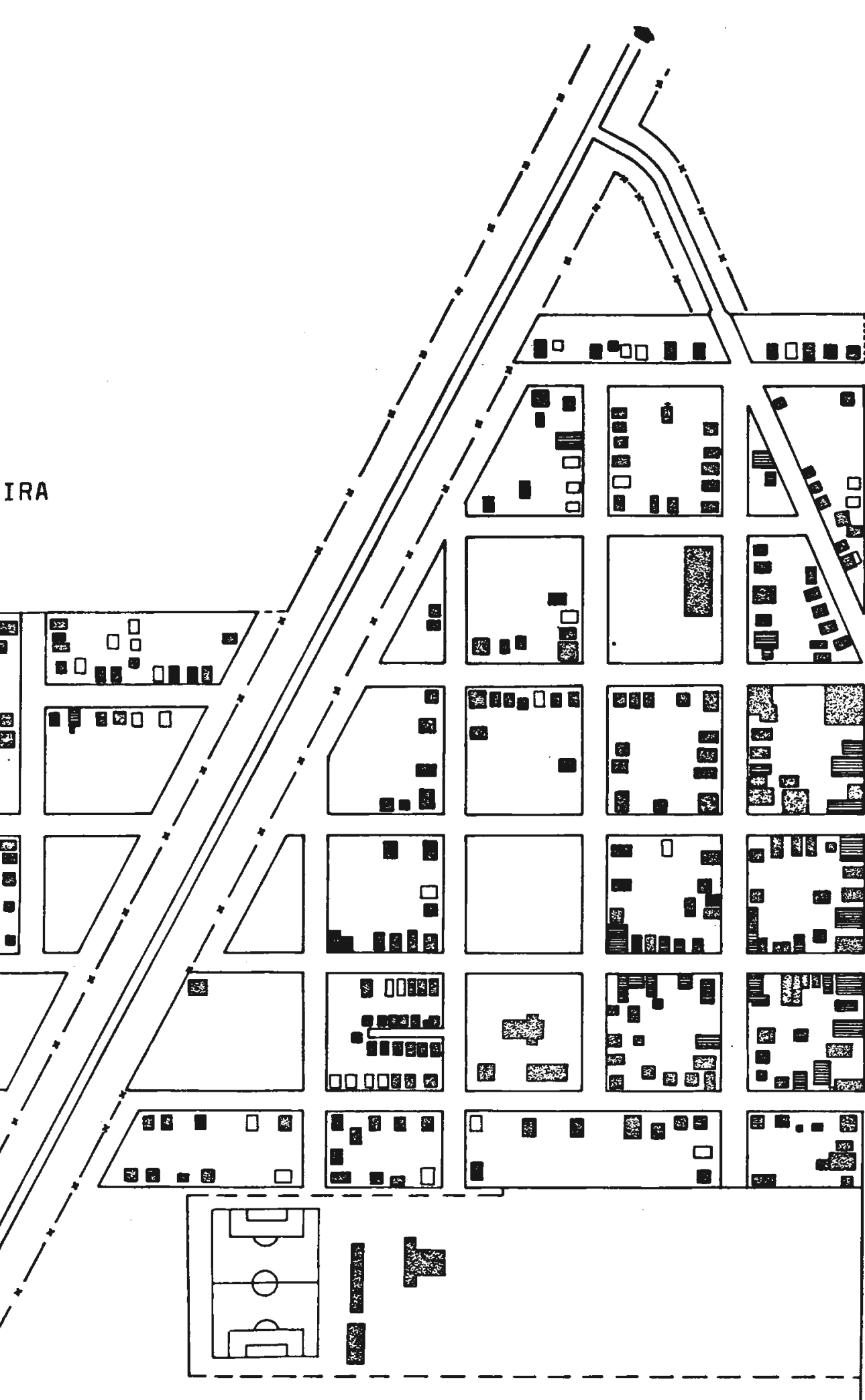
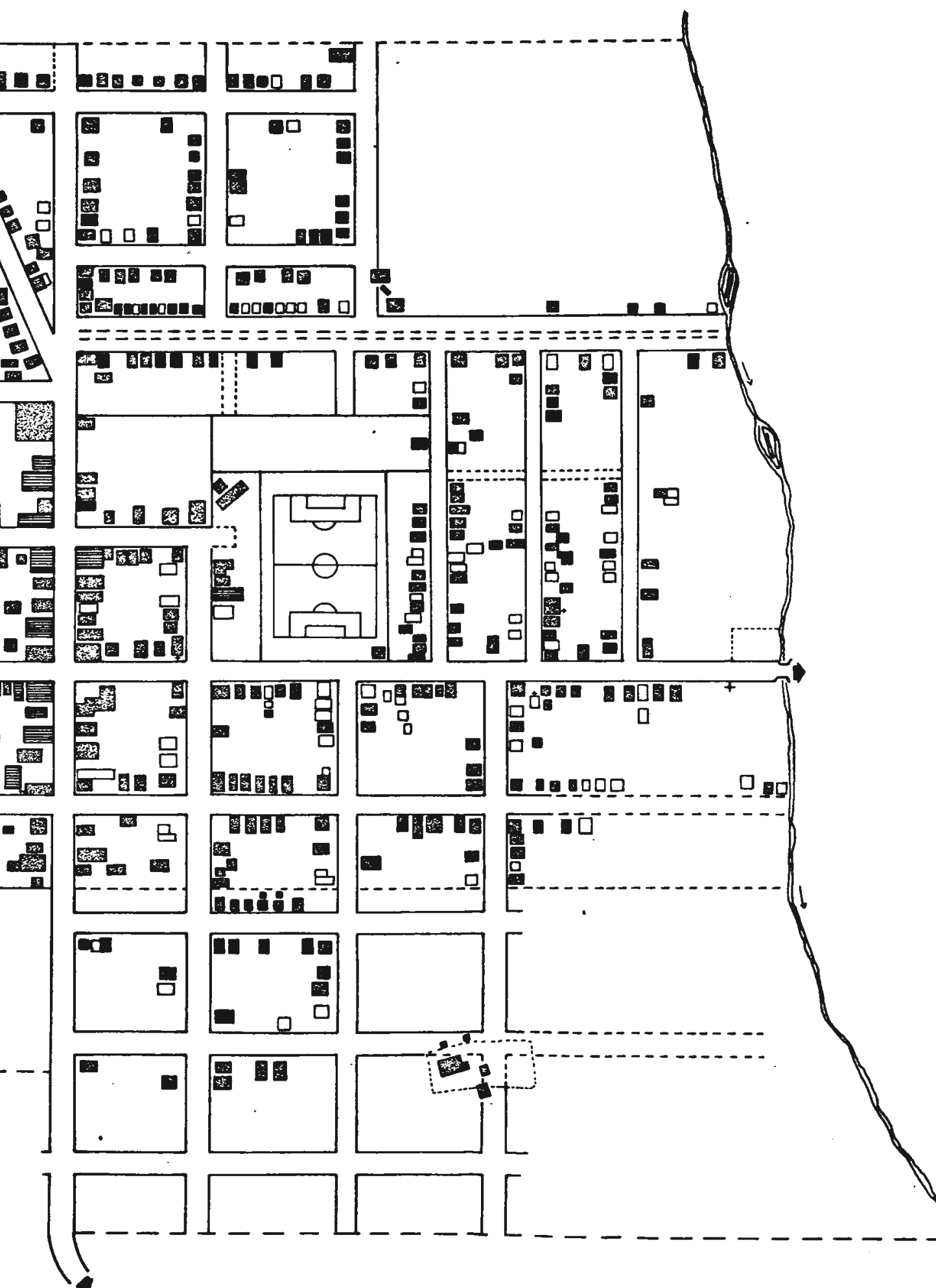

CARTOGRAMA 3 


\subsection{Un perfil da população}

Tendo em vista 0 caráter de urbanizaçäo recente que o núcleo de Tarumã apresenta, a avaliação da origem dessa população pode ser bastante esclarecedora porquanto pode ofere cer em medida mais ou menos exata,o tipo e grau das transformações em curso, afetando essa específica população.

Un exame quanto ao local do nascimento, indica a seguinte origem:

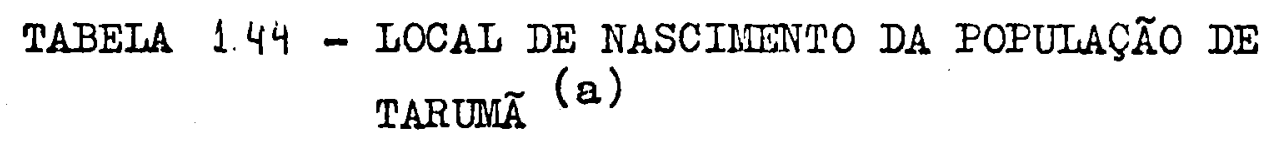

LOCAI

- Nordeste

- Leste

- Estado de São Paulo

- Paraná
$\%$

3.2

12.1

80.6

$4 \cdot 1$

(a) Levantamento de campo em 1976.

No conjunto do Estado de São Paulo, Assis contri bui com $19.5 \%$ enquanto a Micro-Região vizinha - Ourinhos - con tribui com $12.7 \%$.

Um exame de detalhe revela que $44 \%$ da população de Tarumã é nascida nas "águas" vizinhas, a alguns quilômetros do núcleo,tendo ocorrido o deslocamento em meados da década de 
1960 e na década de 1970, com as seguintes distribuições per centuais:

. nas "águas" próximas .......... 44\%

- na $M R H$ - Assis ............. 64\%

- no Vale do Paranapanema ....... $76 \%$

Constatamse que (a) $76 \%$ apresentam origem rural como local de nascimento e $82 \%$ como moradia anterior; (b) os migrantes de outros k'stados, principalmente do Nordeste e Leste do país são antigos migrantes que vieram entre 1930 e 1954, em geral para colheita do algodão e se fixaram na região.

Por outro lado, quando se examina o local de tra balho constata-se $41.2 \%$ trabalham em áreas rurais muito próximas e $37,4 \%$ têm que circular inclusive para fora da região para encontrar trabalho, contando-se aí as colheitas de algodão $n$ o Norte do Paraná, para onde trabalhadores se deslocam com toda a família, deixando a casa fechada por semenas. Mencione-se ainda $21,4 \%$ de população que encontra trabalho urbano com um saldo de $78,6 \%$ da população trabalhando no meio rural, sendo que apenas $2 \%$ são empregados permanentes ou trabalham em sua própria terra, como mostra a Tabela 1.45 a seguir: 
TABEIA 145 - IOCAI DE TRABALHO DOS MORADORES DE TARUMÃ - 1976

\section{IOCAI}

- Tarumã - urbano

- Area rural próxima

- Usina Nova América

- Circulam no Estado/SP e no Paraná

- Trabalhadores permanentes

- Trabalham a própria terra
\% DA POPULACAO

21.4

$15 \cdot 3$

19.8

37.4

4.6

1.5

100.0

Claro está que a liberação de mão de obra cativa que se deu no sul da região principalmente pela substituição de algodão e certais pelo binômio "soja-trigo" explica em alto grau esse processo de urbanização. Th verdade, a população continua trabalhando nas mesmas áreas de onde foram expulsas, muito embora dentro de uma nova relação de produção.

0 ingresso quase nulo de trabalhadores e a existência de $37.4 \%$ de pessoas que sazonalmente buscam trabalho fo ra da região indicam um processo de contração do mercado de trabalho,seja pelas novas formas de organização da produção com alta composição organica, seja pela super exploração do traba- 
Iho,

Um outro indicador da mobilização da população em torno do mercado de trabalho pode ser encontrado pelo exame do tipo de condução utilizada para ir ao trabalho, que indicou 43\% utilizando o caminhão do "gato", 19.8\% caminhões dos pró prios proprietários contratantes, com um total de $62.8 \%$ utili zando caminhão, $18,2 \%$ indo a pé ao trabalho e $11.6 \%$ utilizando condução própria (incluindo-se aí. um grande número de bicicletas) como mostra a Tabela 1.46 abaixo:

TABELA 146 - TIPO DE CONDUÇÃO UTILIZADA PARA IR AO TRABALHO

CATEGORIA $\%$

- Caminhão do "gato" ............. 43.0

- Caminhão de proprietários ........ 19.8

. A pé ....................... 18.2

- Condução própria .............. 11.6

- Ónibus de carreira .............. 7.4

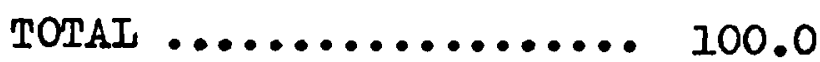

Examinando-se a ocupação atual, a posição na ocū pação e a estabilidade no trabalho, constatam-se os seguintes re sultados, com relação ao total da amostra: 
TABEIA 147 - ESTRUTURA DA POPULAÇO DE TARUMR EII 1976

OCUPAÇ̃O

- Prendas domésticas

- Estudam

- Aposentados e inválidos ......... 2.9

- Trabalham no campo ............ 34.0

- Funcionários urbanos ............ 6.5

- Outros

$$
\text { TOTAL } \ldots \ldots \ldots \cdots \cdots \cdots \cdots
$$

Quento ao contingente de trabalhadores, foi en contrada a seguinte situação:

TABELA 1.48 - POSIÇAO NA OCUPAÇÃO DA POPULAÇÃO QUE TRABAIHA EMI TARUMÃ EM 1976

\section{POSICAOO}

- Empregados

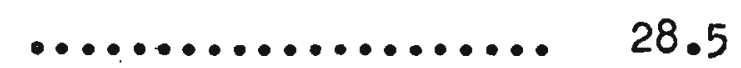

- Por conta própria ............. 15.8

- Unidade familiar de produção ... 5.7

- Volantes ...................... 48.0

- Desempregados ................ 2 2.0

TOTAL ......... 100.0 
No que se refere à estabilidade ao trabalho $25 \%$ da população que trabalha estava nesta situação a menos de um ano, 54,9\% a menos de 3 anos e 74,8\% a menos de cinco anos $\circ$ que demonstra que entre 1970 e 1976 ocorreu uma forte recomposição de estrutura de ocupação, resultado do processo de migra ção.

Unma onálise do perfil etário, de composição de fê mília e da escolaridade demonstra o seguinte:

\section{IDADE EM ANOS}

até 6

até 14

até 18

8.té 25

\section{\% ACURULADA}

18.8

41.9

49.9

62.5

A idade média de população é 23 anos e a mediana 18 anos; O que indica uma população jovem, a quạ em face das novas condições de reprodução, igualadas em termos de custos , aos custos urbanos, e, em face da renda familiar muito baixa, tem sido engajada no trabalho do campo antes de completar. os quatorze anos, em condições de trabalho semelhantes dos aduI tos.

A migração entretanto parece não ter afetado a constituição familiar que se compõem em 99\% da amostra como constituída do casal e da prole, com uma média calculada de 
3 filhos por casal, o que entretanto so explica pelo grande nú mero de casais jovens habitando Tarumã.

A migração parece ter propiciado a escolarização da população, pois no contingente $31,1 \%$ estão em idade escolar (10 e 20 graus) e $33,9 \%$ estudam. Os dados de escolaridade apon tam flutuações no grau de escolarização em fase anterior à migração, afetando a população mais velha. Numa população em que 22,9\% tem idade escolar para estar cursanda o 1으 grau, apresen tam-se entretanto $64,9 \%$ com $1^{9}$ grau incompleto como indica a Tabela 1.49 .

TABEIA 1:49 - GRAU DE ESCOLARIDADE DA POPULAÇ̃̃O DE TARUNÃ EM 1976

CATEGORIA

$\not$

- Analfabetos

20.9

- Assinam o nome ................ 2.7

- Lềne escreven.................... 5.3

. Ie grau incompleto ................ 64.9

- Il grau incompleto ................. 2.9

. 29 grau incompleto ................ 2.9

- 22 graú completo ................... 0.4

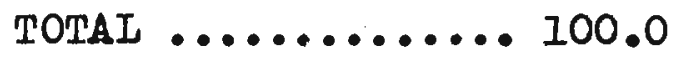


Una análise de renda familiar dentro de classes sjustadas geometricamente teve os seguintes resultados:

TABEIA 1.50 - CLASSES DE RENDA FAMILIAR EM TARUMÃ EN 1976

\begin{tabular}{ccc} 
& \multicolumn{2}{c}{ FREQUENCIA } \\
CLASSES DE RENDA & RELATIVA & ACUMULADA \\
$90-130$ & 4.2 & $\%$ \\
$130-190$ & 6.3 & 4.2 \\
$190-276$ & 4.2 & 10.4 \\
$276-402$ & 4.2 & 14.6 \\
$402-585$ & 14.6 & 18.8 \\
$585-851$ & 37.5 & 33.3 \\
$851-1.237$ & 14.6 & 70.8 \\
$1.237-1.800$ & 14.6 & 85.4 \\
TOTAL & 100.0 & 100.0
\end{tabular}

Os dados acima indicam uma renda familiar média abaixo do salário mínimo vigente na época, o que vem confirmar que as novas relações de produção muito embora não se traduzam por uma agudização da superexploração do trabalho, (que já o corria no interior dos sítios e fazendas) colaboram para a degradação das condições de vida da população, principalmente pe las crescentes dificuldades de scesso 'a alimentação e 'a habita ção sem falar nas condições de acesso ao trabalho, cujo mercado tende a se sazonalizar ainda mais com a incorporação de tẹ 
nologia mais avançada no manejo das culturas.

Whito embora não tenha sido possível medir o volume e o destino das migrações para fora da região, o que ainda se apresenta como alternativa frente ao mercado de trabalho cada vez mais restritivo, cabe examinar, para aqueles que procurarem resistir,quais as condições concretas de existência, tanto material como na condição de segmento social.

0 acesso à terra é feito cada vez mais pela única via da venda em dinheiro da força de trabalho dentro de um mercado restritivo e flutuante. 0 acesso aos meios de vida pas sàm a ser mediados pelo dinheiro (alimentação, habitação), determinando o consumo em pedrões urbanos enquanto o trabalho por padrões não urbanos, sem tradição no cumprimento dos aspectos legais das relações de trabalho estabelecidas, quer quanto ao salário mínimo, quer quanto à proteção do sistema previdenciário.

Por outro lado, as condições de absorção desse contingente ao setor urbano-industrial ao qual efetivamente per tence como reserva de mão de obra, tem esbarrado com dificuldą des crescentes, tendo em vista que a expensão das oportunida des urbanas de trabalho não se dá no mesmo ritmo da liberação da mão de obra rural.

Tem ocorrido, portanto, um processo de marginali zação desses contingentes em relação ao processo produtivo. En tretanto, não deve assumir um caráter estrutural porquanto 
internalização de processos de produção altamente integrados no nível agro-industrial, (responsáveis na região, pela marginalização desses contingentes de trabalhadores) é acompanhada da internalização dos processos industriais da indústria pesada $(25)$, que requerem composição orgânica menor, e que migram a partir dos países desenvolvidos, dentro de uma nova divisão internacional do trabalho.

(25) E caso, por exemplo, da inđústria naval. 


\section{CONCLUSOEES}

A consolidação econômica das áreas sojicultoras po de ser conseguida mais facilmente onde é possível a adoção do "binômio soja-trigo" ou naquelas regiões, onde possam surgir cul turas de inverno para rotação com a soja, tendo em vista a capi talização advinda da rotação mais intensiva do capital imobilizado。

Nos dias que correm, a soja alcançou' a hegemonia em relação ao "binômio" e toda estrutura antes oriẹtada para a produção do trigo volta-se para a produção da soja.

Com o sucesso da adoção do "binômio" e o apareci mento do Brasil como um produtor mundial importsnte começou a ocorrer no. país um processo de "internação" do "complexo-soja" pela instalação de escritórios de comercialização e 10go em seguida a aquisição e expansão do perrque moageiro, pelas grandes corporações tradicionais no setor.

Essa "internalização", que corresponde à expansão da capacidade de processamento confere ao espaço novas características, articulando de um lado (a) "zonas produtoras"de grãos que se caracterizam pela alta taxa de incorporação de tecnolo gia e liberação de mão-de-obra (alta composição orgânica do capital), (b) pelas "zonas industriais esmakadoras", as quais basucamente obedecem, em sua localização a ligação entre as áreas produtoras e as áreas consumidoras que tanto podem ser internas como externas. A indústria voltada para o consumo intermo de óleos comestíveis instala-se a meio caminho dos grandes centros 
urbanos consumidores e dos centros produtores; já a indústria de concentração voltada para a fabricação de alimentação ani mal, instala-se junto às áreas criadoras.

O mercado de consumo interno de óleos é tradicio nalmente organizado, tendo rêdes de supermercados onde o produto é lançado, o mesmo ocorrendo com outros derivados para consu mo na alimentação humana como margarinas e proteínas (estas em menor grau).

Já o mercado de consumo de tortas protéicas sofreu um processo recente de estruturação, ocorrendo no país o aparecimento de "zonas de criação" principalmente avicultoras e suinicultoras, onde ocorre o processo de integração entre pequenos produtores e as indústrias, dentro dos padrões já descritos anteriormente.

Enquanto no Rio Grande do Sul, no Paraná e em são Paulo definem-se zonas produtoras de grãos de um lado e zonas industriais de outro, como se verá, no Estado de Santa Catarina concentram-se as mais importantes zonas criadoras de Concórdia e Chapecó, cada uma delas guardando características próprias, que se explicitam tanto ao nível do espaço onde ocorrem, na especialização de atividades, maior ou menor concentração fundîa ria como ao nível da organização social da produção.

As zonas produtoras de grãos se caracterizam pelo alto padrão técnico, pela liberação e/ou sazonalização de mãode-obra; por outro lado, nas áreas criadoras, o mesmo processo produtivo reproduz a pequena propriedade baseada na mão-de-obra familiar. 
Essa aparente contradição não corresponde ao caráter funcional que as relações de produção mais atrasadas desempenham na acumulação do capital, mas um avanço e um aprofunda mento dos processos de extração do sobretrabalho, dentro de pro cessos produtivos onde se torna cada vez mais difícil ao produtor direto a retenção de renda absoluta da terra。

A expropriação dos trabalhadores alcançou un caráter tão amplo e tão vasto e planetário, possibilitando o domí nio em amplas esferas da produção pela monopolização de meios modernos de produção, que confere ao monopólio da terra um papel cada vez mais relativo.

\section{A terra só é meio de produção quando e enquanto} possui potencial produtivo, isto é, quando ao ser fecundada pelo trabalho vivo produz valor de uso. Caso contrário, passa a ser apenas o suporte dos meios de produção que devem ser adqui ridos。

Se a terra fosse um recurso natural potencial produtivo naturalmente renovável isto não aconteceria. Tendo em vista que ela se esgota e perde esse potencial, a sua reprodu ção como meio de produção deve ser feita com a adição, constante, daqueles elementos que de alguma forma ou de outra, foram consumidas (ou destruídas) no processo produtivo (no caso a matéria orgânica, os nutrientes minerais, etc.) De forma que a simples mönopolização desses insumos necessários a reprodução da terra como melo e produção corresponde tendencialmente a uma monopolização da terra, ou ao impedimento da formação da renda absoluta. 
Um argumento em contrário seria aquele que aponta, de um lado, a necessária junção do suporte aos insumos para a re produção da terra como meio de produção e de outro lado, o monopólio da propriedade privada do suporte, o que tenderia a man ter a renda absoluta。

A condição da reprodução da força de trabalho é que haja sempre um saldo de produto depois de certo período de produção em que parte do produto é consumido na própria produ ção.

Considera-se que este saldo sempre ocorre mesmo nas condições mais rudimentares de produção, e que a adição de qualquer instrumento adequado ao fim aumenta enormemente o produto.

Tendo em vista que a terra produtiva é um recurso não naturalmente renovável em condições de exploração continuada, o monopólio dos demais meios tenderão a suplantar o monopólio da propriedade privada, sem entretanto destruí-la necessa riamente como forma histórica.

0 estudo em questão, procura demonstrar que o processo de formação da "zona produtora" (de grãos) consolida a propriedade da terra, elimina formas atrasadas de relação de produção, transforma o proprietário no produtor direto, aumenta enormemente a composição orgânica do capital. Dentro das condicões sociais em que ocorre, retira dele a possibilidade (que a propriedade privada da terra legalmente the confere) de sair do ciclo produtivo, do qual ele se torna um segmento, tendo em 
vista que o ciclo produtivo agrícola passa pela indústria de transformação de insumos e de máquinas agrícolas, pela indús tria de processamento, sendo esses diversos momentos internedia dos pelo capital financeiro, que controla os ritmos do pro cesso de produção e da metamorfose do capital-dinheiro em merca doria e da mercadoria em capital-dinheiro, tendo em vista a reprodução equilibrada e eficiente do padrão de acumulação.

A presença do capital financeiro tem a função de contribuir para a adoção eficiente dos meios no interior do pro cesso produtivo global.

No caso em questão há que lembrar entretanto que essa muptura se dá graças a uma ação conjunta do Estado e do capital monopolista. Seu papel se dá pela alocação maciça de meios a custos reais muito baixos em setores específicos da pro dução, o que se torna possível pelo seu poder de socialização dos custos da capitalização dos setores escolhidos.

A marginalização mesmo que temporária de amplos segmentos da população ligados à produção direta, a degradação de sua condição de vida e a injustiça social têm como contrapar tida a eleição de certos segmentos (detentores principalmente de terra) como participantes do ciclo produtivo. Isto não sieni fica entretanto a reprodução do proprietário da propriedade prí vada da terra como um rentista, que enquanto tal, terá a condição de extrair rendas da utilização dos meios de produção que detém. Sua reprodução se dará necessariamente enquanto secmento do ciclo produtivo ao qual se integrou e do qual não tem contro le.

As "zonas produtoras" integradas ao processo produ 
tivo são o espelho de cada momento do processo ao qual ela se vincula mais diretamente. Depuradas as contradiçoes específicas inerentes ao processo de ruptura e integração, ainda assim se configura sua diversidade, umas em relação às outras, diversida de esta, que não é senão a materialização de estratégias de implantação de momentos do processo produtivo, não configu rando, em si, um caráter contraditório.

A destruição e a manutenção da pequena propriedade correspondem a uma mesma "racionalidade" e são formas adequadas a diversos momentos do processo produtivo.

A "leitura do espaço" como leitura da história não pode ser feita diretamente, sobre un "recorte". No recorte (necessário) inscrevem-se apenas algumas "pistas", segmentos por vezès contraditórios.

Feito o "recorte" é necessário imediatamente sair dele. Como? Está "escrito" no "recorte"... 
ASSEMBLEIA LEGISLATIVA DO R.G.DO SUL - 19 SIMPOSIO NACIONAL DA SOJA - Porto Alegre, 1.975

BARRIGUELLI, J.C. - Conflito e Participação no Meio Rural

- a greve da Usina Nova América (1962). II Encontro Nacio nal, e Estudos Rurais e Urbanos,

- Cadernos do CERU, no 12, São Paulo, 1979.

BARROS, PASTORE e RIZZIERI - A Evolução recente da Agricultura Brasileira - in Estudos sobre a Modernização da Agricultú ra Brasileira - IPE - USP, Monografias no 9 - São Paulo, 1977 .

BAULIG, H - Amérique Septentrionelle . A.Colin - Paris.

BERLAN ET ALLII:- Le Devellopement du "Complexe - Soja" Revue ' Tiers Monde, t.XVII, n8 66, Abril/Junho de 1976.

BERNARDES, N. Bases Geográficas do Povoamento do Estado do Riio Grande do sul. Boletim Geográfico no 171 e 172, IBGE, Rio de Janeiro.

BORTOLUzI, C.R.D. - Ánálise de Fatores. Associados, Area de Pro dução do Arroz no Rio Grande do Sul. Porto Alegre, 1978, mimeo.

BRAY, S. "A Cultura de Cana-de-Acucar no Vale do Pararapanema" Tese de doutoramento, 1980, mimeo.

BRANDT, V.C. "Do colono ao bōia-fria: Transformações na Agricul tura e Constituição do mercado de trabalho na Alta Soroca bana de Assis, Estudos CEBRAP, no 19, 1977. 
BRAVERMAN, H. Trabalho e Capital Monopolista, Zahar Ed., 1977.

CAMARgo, J.F. de - Crescimento da População no Estado de são ' - Paulo e seus aspectos econômicos. IPE-USP, Ensaios Econōmicos n8 14, 1981 .

CLOUGH E MARBURG - The Economic Basis of American Civilization T.J.Crowel Co. New York, 1968.

CORADINI, $0_{i}$, Frederic, A, "Agricultura, Cooperativas e Multinacionais - Zahar - R.Janeiro, 1982.

CUNHA BAYMA, o Trigo; volumes I e II, Rio de Janeiro (Serviço de Informação Agrícola) Ministério da Agricultura, 1960.

FUNDAÇAO CARGILL "A Soja no Brasil Central", 1977.

GEORGE, Pierre - A Economia nos Estados Unidos, Publicação D.Quixote, Lisboa, 1970.

GRAZIANO DA SILVA, J.e Gúasquez, J.E. - Diagnóstico Inicial ' do volante em São Paulo - in Mão-de-obra volante na Agricultura - CNPQ/UNESP, Polis, 1982.

HOUCK, RYAN E SUBOTNIK

"Soybeans and their Products - Markets, Models and PolicyUniversity of Minne $\not$ sota Press - Minneapolis, 1972.

KNIGHT,P.-Substitulção de Importações na Agricultura Brasileira. A producão de trigo no Rio Grande do Sul.

MORSE, W. - History of soybeans production. Interscience, vol.1, 1950 .

NAGATA, T. - Agro-Genecological Aproaches in the Variety Diffe rentiation in Soybeans, Glycine Max (I) Merrill in Procee dings of a Symposium on Tropical Agricultural Reseaches. Tokio, Tropical Agricultur al Center. 
PEBAYLE, R. - Eleveurs et Agriculteurs du Rio Grande do Sul (Brésil) Université de Lillé III, 1974, mimeo.

PIMENTEL GoMes - A Soja, Nobel S.A. - 4 ą Edição, São Paulo.

QUEDA, O. - Intervenção do Eśtado e a Agro-Indústria Açucareira Paulista. Tese de doutoramento, ESALQ-USP, 1972, mimeo.

ROHDE, G.M. - A história da Soja - lo Simpósio Nacional de Scja, Porto Alegre, 1975.

SANDRONI, P. - Questão Agraril e Campesinato - "A Funcionalida de" da Pequena Produção Mercantil - Ed.Polis, São Paulo, 1980 .

SCHILLING, P. TRIGO - O trigo e o Latifundio no Rio Grande do Sul - ISEB - Rio de Janeiro, 1962.

TEIXEIRA, E.F. - o trigo no sul do Brasil - Ed.Linotype - São Paulo, 1958 .

UNCTAD

" Arusha Programme e Fao Agriculture.Horizon 2000, 1978.

VERGOPOULOS, K. - L'agriculture periphérique. Revue du Tiers ' Monde, t. XXII, no 85,1981 .

VON DOELIINGER et allii - A politica Brasileira dé Comércio Ex terior e seus Efeitos: $1967 / 73$ - IPEA-INPES, Rio de Janeiro, 1974, p. 81 a 83 . 
A PENDICES 
BANESPA

DERAL

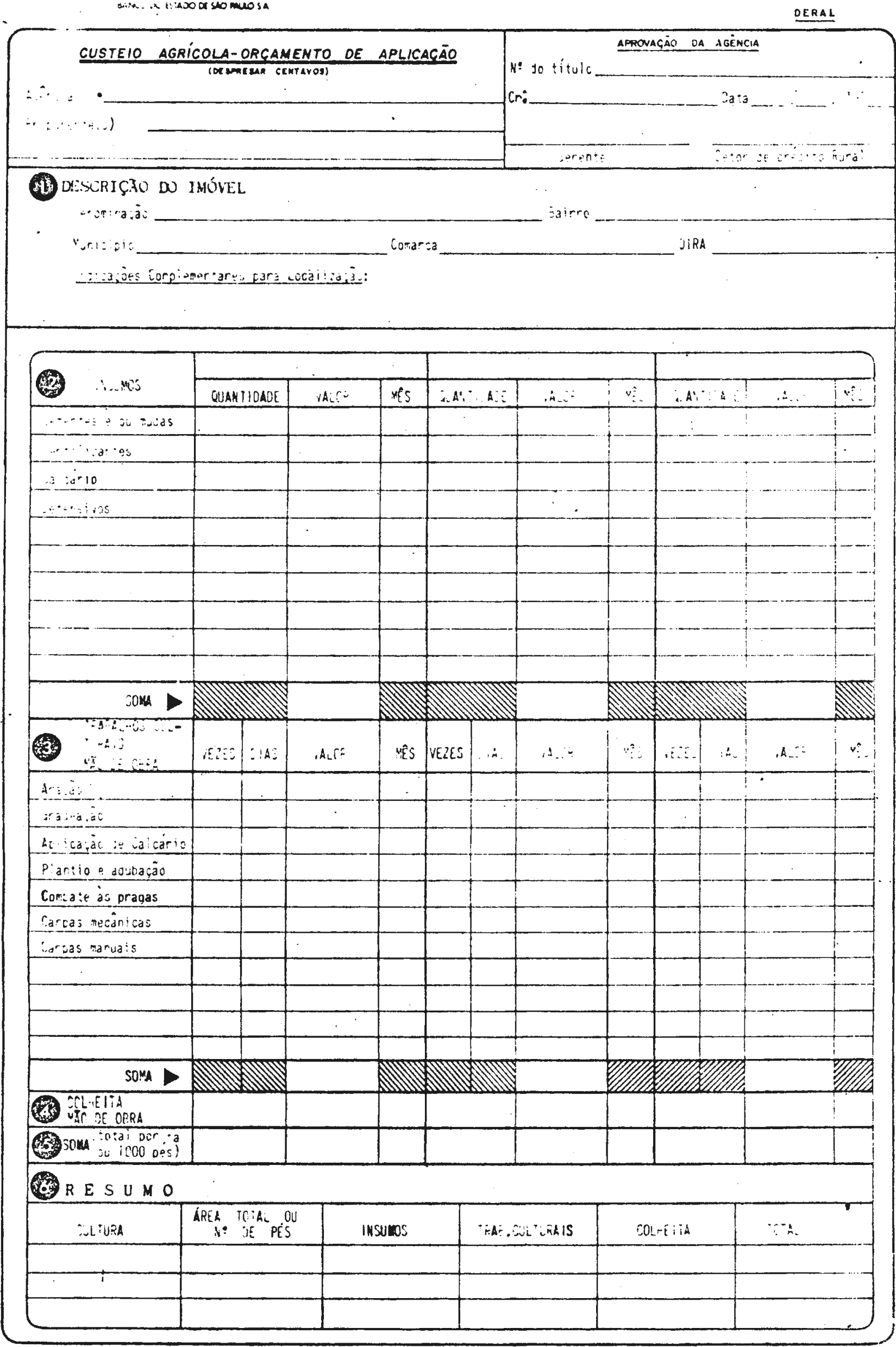

Nim/01-iL $(8 / 79$ 
CROAUGRAMA DE LTILIZiAgAO

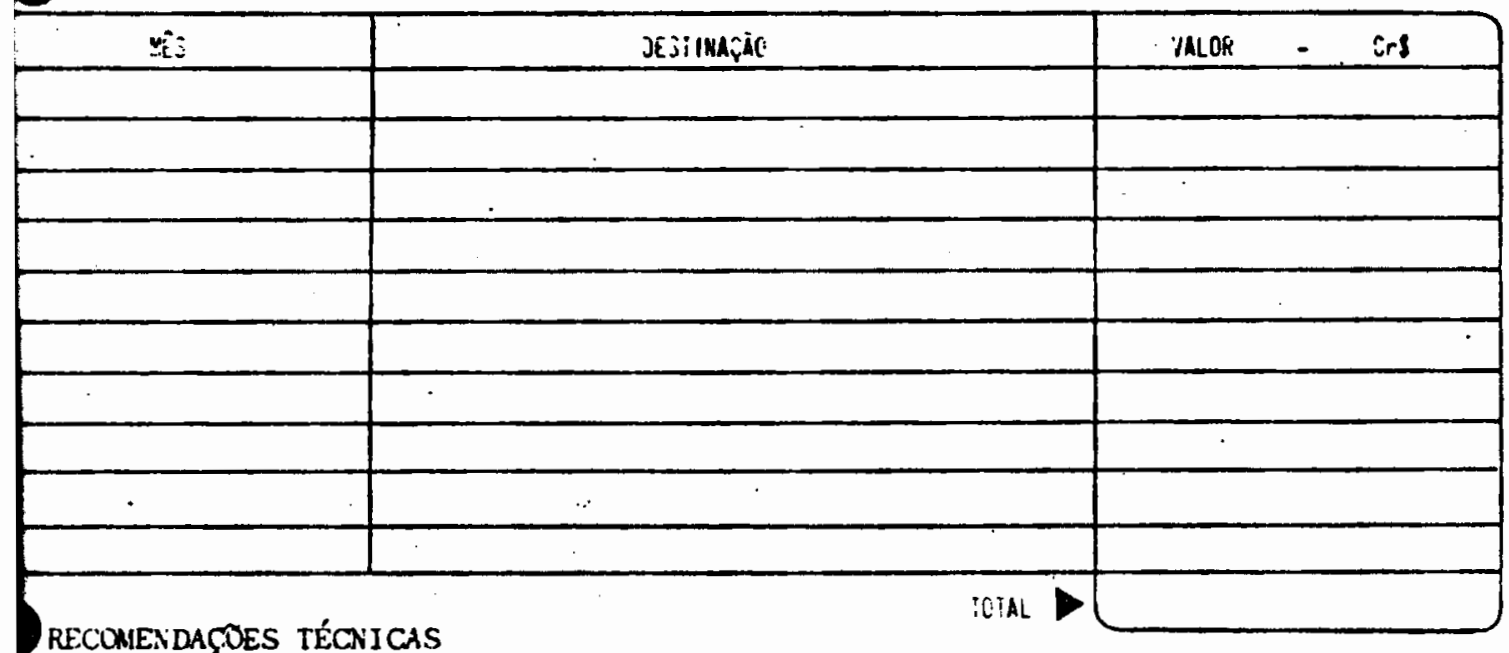

\section{TERMO DE COMPROMISSO}

Comprometo-me a ooservar fielente as recomensaçoes técnicas acima especificasas, :or

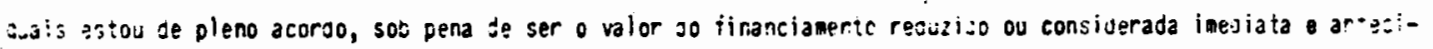
canan:e vencioa a céoula do Crécito Rüral corresponjente.

Frogoromense:
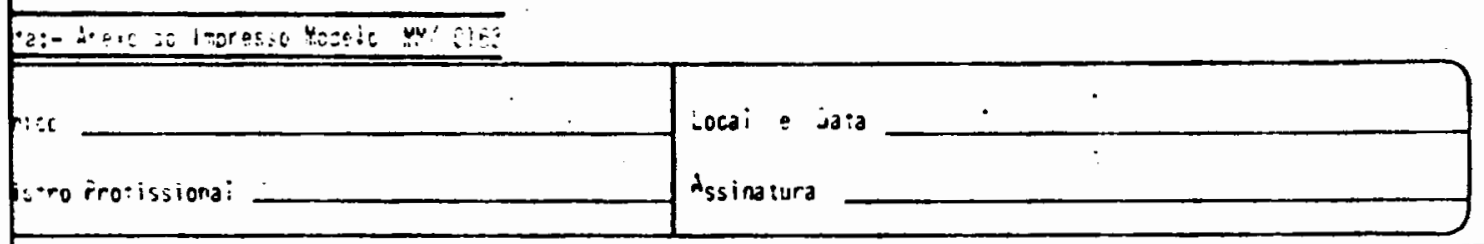


\section{CEDULA RURAT PIGNORATICIA}

INo EAC- / Vencimento em 30 de Novembro de 1978.

$$
\text { c. } \$ 267.000,00
$$

Aos 30 dias do mês de Novembro de 1978, pagaremos por esta Cédula Rural Pignoratícia ................................. BANCO DO BRASII $S . A$. ou a sua ordem a quantia de: (DUZENTOS E SESSENTA E SETE MII CRUZEIROS).em moeda corrente, valor do crédito deferido para financiamento de CUSTEIo da(s) lavoura(s) seguinte(s), formada(s) no(s)pe ríodo(s) agrícola(s), indicado(s), no(s) imóvel(is) abaixo des crito(s):

$\begin{array}{rlllll}\text { TRIGO: } & \text { - abril de } 1978 \text { a set. de } 1978-40 \text { alq. } 96,80 \text { ha } \\ - & \text { de } 19 \text { a } & \text { de } 19 \text { - alq. } & \text { ha } \\ - & \text { de } 19 \text { a } & \text { de } 19-\text { alq. } & \text { ha } \\ - & \text { de } 19 & \text { a } & \text { de } 19- & \text { alq. } & \text { ha }\end{array}$

\section{DISCRIMINAÇ̃̃O DO CUSTEIO Épocas TRIGO:}

1 Parte

a) Compra de inseticidas adubos sementes

oport. 28.000 , oport. 43.109 , imed. 57.000 ,

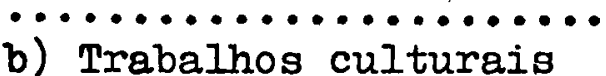
preparo das terras plantio c/adubação tratos culturais imed. imed. 43.000, imed. 16.000, -

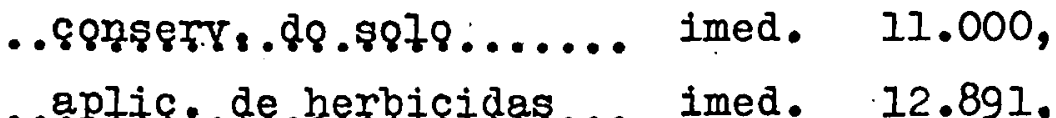

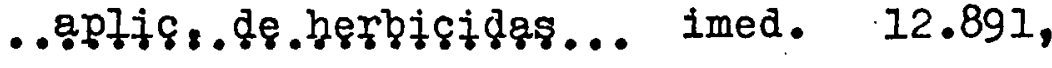
..8p7j8..de.jngeticidar.. imed. 16.000,
2 Parte - Colneita de:
2.000 ses. $X \quad 20,00$
40.000, 
e que será utilizado do seguinte modo: depois de inscrita esta Cédula: imediatamente - $\operatorname{cr} \$ 98.891,00 ;$ oportunamente - co $\$$ 123.109,00, com pagamento direto as firmas vendedoras de adu bos, sementes e inseticidas;

e as parcelas relativas à colheita só serão utilizadas à medida que for sendo colhido o produto, de acordo com as comunicações que o(s) EMITENTE(S) se obriga(m) a fazer oportunamente ao BANCO DO BRASIL S.A., por escrito, e, ainda de conformidade com a segunda parte deste orçamento: Fica desde já autorizado - BANCO DO BRASII S.A., a efetuar diretamente aos fornecedores os pagamentos correspondentes às aquisições supramencionadas. Os juros são devidos à taxa de - vide verso por cento ao ano, pagáveis em 30 de junho, 31 de dezembro, no vencimento ena Iiquidação desta Cédula, podendo ser capitalizados.

o pagamento será efetuado na praça de

Estado de São Paulo. Os bens vinculados são os seguintes: Fm PENHOR CEDULAR do primeiro grau e sem concorrência $a(s)$ COLHEI $\mathrm{TA}(\mathrm{S})$ da(s) lavoura(s) do(s) EMITENTE(S), do(s) produto(s) a = baixo indicado(s), formada(s) no(s) período(s) agrícola(s) no orçamento retro, a saber:

TRIGO: 2.000 (dois mil) sacos de $60 \mathrm{kgs.IÍquidos,} \mathrm{no}$ valor unitário de c\$238,20 e total de ...... c.476.400.00

TOTAL: QUATROCENTOS E SETENTA E SEIS MIL E QUATROCEN TOS CRUZEIROS ...................... C... $476.400,00$

Imóveis de localização dos bens apenhados: 1)- fazenda ".

", lugar denominado "égua do. "no munic. de I-SP, de propriedade do imitente. ,cfe. regs. $\mathrm{n} \mathbf{9}_{\mathbf{8}}$ :

"Água do , todos do CRI local; 2)- faz. -SP, comarca de'Sta.Cruz do R.Pardo-SP, de propriedade dos emi tentes

$$
\text { , do CRI 10cal.- }
$$

$\therefore$ cfe. registro $\mathrm{n}^{\overline{2}}$

Cobranca de Juros: Os juros, pagáveis em 30 de jựho, 31 de de zembro e na liquidação desta cédula, são devidos às seguintes. taxas: I)-Nihil, sobre o valor de c $\$ 43.109,00$, destinado à aquisição de fertilizantes, constante do orçamento; II)- 15\% (quinze por cento) ao ano, sobre as denais parcelas, no valor de c $\$ 223.891,00$, destinadas à compra de bens e custeio dos serviços consignados no orçamento, podendo ser capitalizados. 
PRACA DE DEPÓSITO: Oa bens apenhados serão, depois de colhidos, depositados a ordem do BANCO DO BRASII S.A., em armazens desta praça, ou outra que for, por ele previamente aceitos, por es crito.

REMICÃO DOS BENS APENHADOS: Para remição dos bens apenhados, quando por mim (nos) pretendida, obrigo-me (obrigamo-nos) a re colher ao BANCO DO BRASII S.A., previamente, para amortização da presente Cédula, $80 \%$ (oitenta por cento) do valor dos bens a liberar, podendo ser exigido o preço integral de venda, se superior.

Adesão zo PROAGRO Manifesto(amos) a minha(nossa) adesão ao Pro grama de Garantia da Atividade Agropecuária (PROAGRO), insti tuído pela lei $\mathrm{n}^{\mathrm{9}} 5.969$, de 11.12 .73 , sobre o qual declaro(a mos) conhecer o seu Regulamento e as normas respectivas, especialmente as contidas no impresso anexo que, para todos os fins de direito, passa a integrar o presente instrumento.

Adicional de 1\% Além dos juros, obrigo-me(obrigamo-nos) a pa gar ao Banco do Brasil S.A. o adicional à taxa de 1\% (hum por cento) ao ano, exigível em 30 de junho, 31 de dezembro, no ven cimento e na liquidação desta Cédula. A falta de pagamento des se adicional nas datas aprazadas sujeitar-me-á (sujeitar-nos á) à multa de $10 \%$ (dez por cento) sobre o seu valor, por mês ou fração que transcorrer depois de 30 dias a contar da data $\underline{\underline{S}}$ tipulada para o seu pagamento.

MULTA: Em caso de cobrança em processo contencioso ou não, judicial ou administrativo, responderei(emos), ainda, pela multa de $10 \%$ (dez por cento) nos termos do artigo 71 do Decreto- Iei ne 167, de 14-2-67.

$$
\text { .. (SP), } 04 \text { ABR } 1978
$$
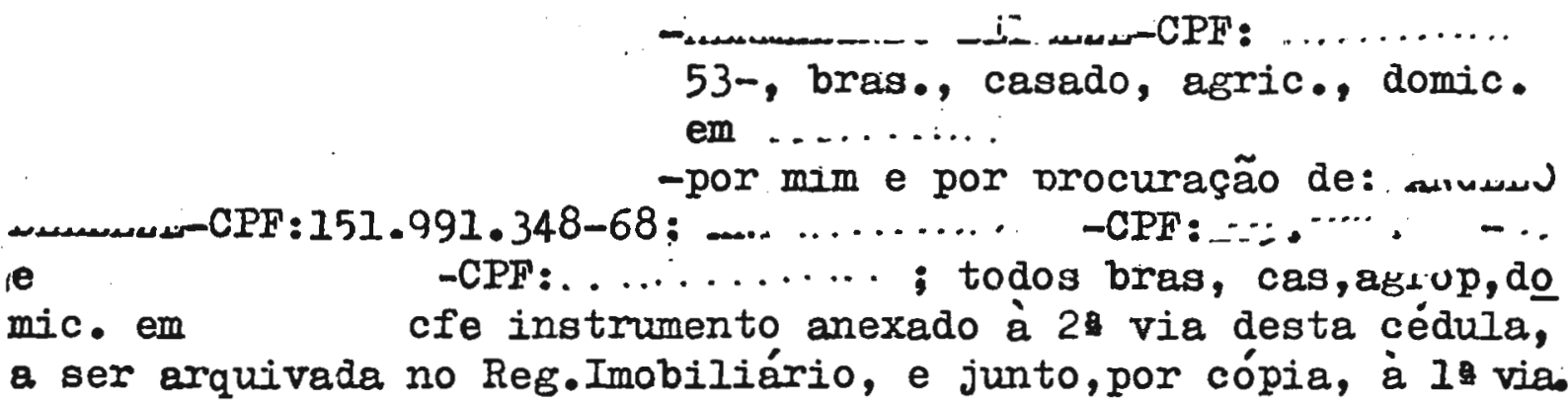


\section{CEDULa RURAL PIgNORATICIA}

Aos 30 de novembro de 1978 pagarenge por esta Cédula Rural Pignoraticia ao BANCO DO BRASIL S. A., Sociedade de Economia Mista, com sede em Brasilia, Capital Federal, Inscrito no Cadastro Geral de Contribuintes do Ministerlo da Fazenda sob n." 00.000.000/0223-22, ou a sua ordem, a

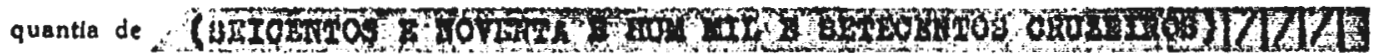

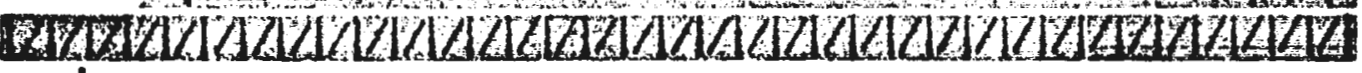

em moeda corrente, valor do crédito deferido para linanciamento de custelo da lavoura de TRIGO, a ser fundada no periodo agricola de março a setembro de 1978, numa área de 100,0 alquelres paulistas, equivalente a 242,00 hectares, no(s) imóvel(eis) discriminado(s) na cláusula "IMOVEL DE LOCALIZAÇAO DOS BENS APENHADOS" e que será utilizado do seguinte modo:

\begin{tabular}{|c|c|c|c|c|}
\hline $\begin{array}{c}\text { Defensivos } \\
\text { Crs }\end{array}$ & $\begin{array}{c}\text { Fertlizantes } \\
\text { Cr } \$\end{array}$ & $\begin{array}{c}\text { Sementes } \\
\text { Cr } \$\end{array}$ & $\begin{array}{c}\text { Trabalhos Culturais } \\
\text { Cr } \$\end{array}$ & $\begin{array}{c}\text { Colhetta } \\
\text { Cr } \$\end{array}$ \\
\hline $50,000,00$ & $276,400,00$ & $171,000,00$ & $251.300,00$ & $.41 .700,00$ \\
\hline
\end{tabular}

nas segulntes condiços: Imediatamente, Ci $\$ 251,300,00$

(preparo da terso plantio e tratos culturais) e Cr $\$$ durante a colbeita, translesidas as importap ofestivas, quando Uberadas, para crédito de minha(nossa) conta de depósitos, mediante lançamentarop as. As verbas destinadas às aquisiços de DEFENSIVOS (Inseticidas, Fungicidas e Hopicida), FERTILIZANTES e SEMENTES, serão pagas pelo Banco diretamente aos fornecedores rit van apresentaşäo dos respectivos comprovantes. COBRANÇA DE JUROS: Os juros, pagáveis gen d) Júnho, 31 de dezembro e na liquidação desta Cédula, são devidos as seguintes taxas: I)- Nihizhbed valor de CI $\$$

destinado a aquisição de fertilizantes constantes do oran (onto (I)- \%( por cento), ao ano sobre as demais parcelas, no valor de Cr\$

pagamento ou custeio dos serviços, consignados ho dramento, podendo ser capitalizados. Näo constituindo

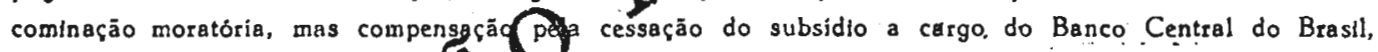
vencida e não paga esta Cédula of po-me(obrigamo-nos) a pagar ao Banco do Brasil S. A., juros a taxa de \%( perapto to ano sobre a verba relativa à aquisição de fertilizantes, exigivels em 30 de junho, 31 de dezembro na liquidaçáo deste instrunsento, podendo ser igualmente capitalizados.

O pagamento elturado na praça de Assis, Estado de Sáo Paulo.

OS BENS VNCULADOS SAO OS SEGUINTES:

EM PENHOR CEDULAR DE PRIMEIRO GRAU, sem concorréncia de terceiros, o produto da lavoura abaixo: TRIGO EM GRAO - Periodo agricola de março a setembro/78:

sacos de $60 \mathrm{~kg}$. cada a $\mathrm{Cr} \$ \quad$ saco, no total de Cr\$ IMOVEL DE LOCALIZAÇAO DOS BENS APENHADOS:

Os produtos apenhados seräo depols de colhidos, depositados a ordem do BANCO DO BRASIL S. A., em armaźna -desta praça, por ele previamente aceitos. - ..... ADESÃO AO PROAGRO: - Manifesto(amos) a minha(nossa) sdesão ao Programa de Garantla da Atlvidade Agropecuárla (PROAGRO), instituida pela Lel n." 5.969, de 11-12-73, sobre o qual declaro(amos) conbecer o sefi, régulamento $\mathrm{e}$ as normas respectivas, especialmente as contidas no impresso anexo que. para todos os fins'ide direlto, passa a integrar o presente instrumento.

Adicional de 1\%: - Obrigọme jobrigamo-nos) a pagar a Banco do Brasil S.A. o adicional de $1 \%$ (um por centol ao ano, exigivel foritamęte com os furos.

Obrigação Especial: - Obrigo-me (obrigamín-th̆os) na formação de minha(nossa) lavoura, a execução do terraceamento e de obras conservacionistas do dón lo; -não ser que recomendaços tecnicas admitam especificamente dispensável a medida, en lace a inexisténcia ou de ser quase nula a declividade do terreno:

Seguro dos bens vinculados: - Autorizo(mos) o BANCO DO' BRASIL. S. A., a promover por míta (nossa) conta os seguras sobre os bens descritos. Fica expressamenty entendido no entanto que nenbuma responsabilldade a mesmo Banco cabera quanto aos prejuizos porvenţura desorrentes de qualquer omlssāo ou Isregularidade na cobertura dos riscos aludidos.

Remiçáo: - $80 \%$ (oitenta por cento) do valor dos bens a liberar.

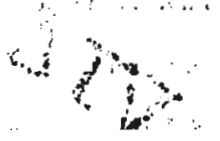


LABEIA B2.1 CONDIÇTO IEGAL DAS TERRA' PO PORCEMTAGEM SOBRE A AREA TOTAL DE CADA CATEGORIA KA MRE -. ISSIS POR :ERIODOS SELECIONADOS

\begin{tabular}{|c|c|c|c|c|c|c|c|c|c|c|}
\hline \multirow{3}{*}{$\begin{array}{l}\text { Muntclpios } \\
\text { da } \\
\text { MRH - Assis }\end{array}$} & \multirow{2}{*}{\multicolumn{2}{|c|}{ Total }} & \multicolumn{4}{|c|}{ Unlca } & \multicolumn{4}{|c|}{ Mista } \\
\hline & & & \multicolumn{2}{|c|}{ Pxór 1as } & \multicolumn{2}{|c|}{$\begin{array}{l}\text { Ar enda- } \\
\text { das }\end{array}$} & \multicolumn{2}{|c|}{$\begin{array}{l}\text { Proprias } \\
\text { e Arre:d. }\end{array}$} & \multicolumn{2}{|c|}{$\begin{array}{l}\text { Proprias } \\
\text { e Ocupad. }\end{array}$} \\
\hline & 70 & 75 & 70 & 75 & 70 & $7 E$ & 70 & 75 & 70 & 75 \\
\hline & 100 & 100 & 100 & 100 & 100 & 100 & 100 & 100 & 100 & 100 \\
\hline Assio ............ & 9,6 & 9,8 & 9,5 & 10,1 & 7,4 & 6,0 & 43,5 & 29,9 & 10,1 & 18,4 \\
\hline Borá ............ & 2,1 & 2,3 & 2,2 & 2,4 & 1,7 & 0,8 & 2,6 & 0,1 & 3,0 & - \\
\hline Campos Novos Pta. & 7,7 & 7.5 & 8,4 & 7.7 & 2,6 & 6,6 & $-\cdot$ & 1,3 & 14,6 & 4,7 \\
\hline Candido Mota .... & 8,1 & 7,6 & 7,3 & 7,2 & 4,3 & 11,7 & 5,0 & 10,4 & 15,8 & 10,2 \\
\hline Cruz’́lıa ....... & 4,1 & 3,4 & 3,8 & 3,4 & 7,8 & 4,3 & 4,4 & 3,3 & 4,0 & 0,5 \\
\hline Echaporã ........ & 7,9 & 8,5 & 8,4 & 9,2 & 5,8 & 1,6 & $\cdot$ & 3,7 & - & - \\
\hline Florínea ........ & 2,8 & 2,9 & 2,7 & 2,7 & 5,0 & $5: 4$ & 6,8 & 2,8 & 4,3 & - \\
\hline Ibirarema ....... & 3,5 & 3,6 & 3,4 & 3,5 & 3,4 & 3,0 & 0,2 & - & 0,5 & - \\
\hline Iutec1a $\quad \ldots \ldots \ldots$ & 6,1 & 7,0 & 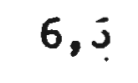 & 6,7 & 3,6 & 10,0 . & 9,1 & 4,6 & - & 26,0 \\
\hline Maraca1 $\ldots . . . .$. & 7,6 & 6,7 & 7,5 & 6,5 & $8,6^{\circ}$ & 8,2 & 5,0 . & 22,4 & 2,3 & 1,5 \\
\hline Oscar Bressane .. & 3,3 & 3,4 & 3,4 & 3,3 & 2,5 & 3.6 & 0,4 & 3,7 & 6,8 & 4,0 \\
\hline Palmital $\ldots . . .$. & 7,9 & 8,2 & 6,9 & 7,7 & 16,7 & 14,2 & 5,1 & 7,6 & 19,2 & 19,1 \\
\hline Paraguaçu Pta... & 15,3 & 15.3 & 17,9 & 16,0 & 5,7 & 5,8 & 13,2 & 7,3 & 3,7 & 11,6 \\
\hline ....... & 4,2 & 4,2 & 4,5 & 4,6 & 1,0 & 2,5 & 3,6 & 1,9 & 23,3 & - \\
\hline Quaté.......... & 2.2 & 9.2 & 9.0 & $\varepsilon, 5$ & 13,6 & 15,0 & 0,5 & $0,4$. & 2,0 & 3,6 \\
\hline
\end{tabular}




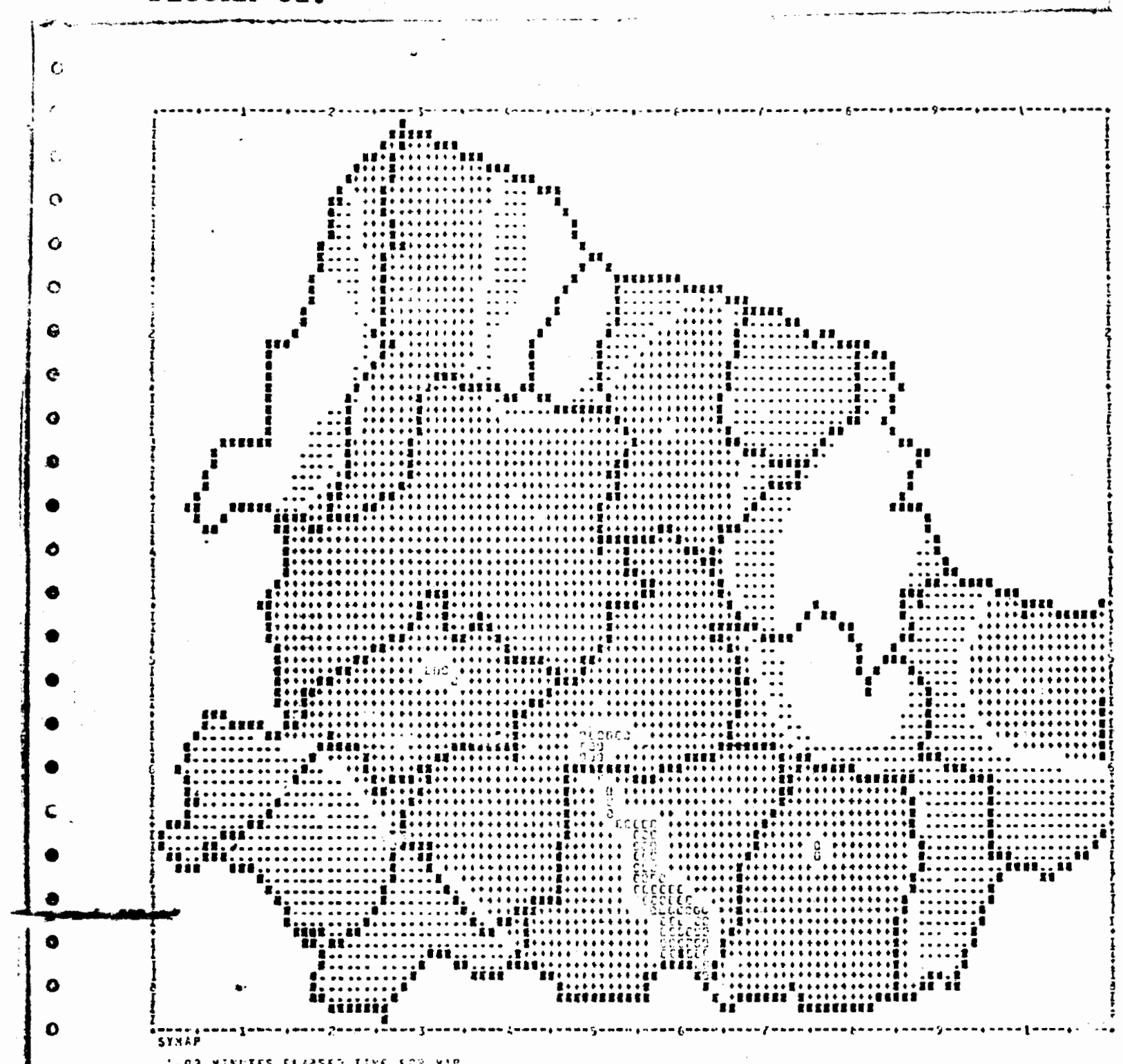

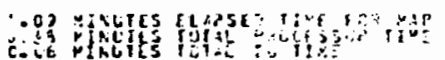

wite of our $=230 \mathrm{si}$

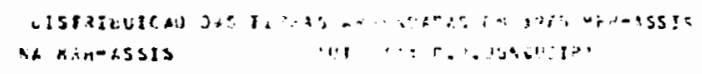

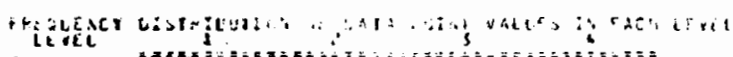

STMBLL

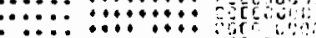

rize.

3

and 
tabeia Al. - GRUPOSDE AREA DE PRODUÇ̃̃o DA SOJA NO ESTADO DE SÃO PAULO EM 1970 E 1975

\begin{tabular}{|c|c|c|c|c|c|c|c|c|}
\hline \multicolumn{3}{|c|}{$\begin{array}{c}\text { GRUPOS DE AREAS } \\
\text { (HA) }\end{array}$} & \multirow{2}{*}{\multicolumn{2}{|c|}{$\begin{array}{c}\% \\
\text { AREA } \\
1970-1975\end{array}$}} & \multirow{2}{*}{\multicolumn{2}{|c|}{$\begin{array}{c}\% \\
\text { PRODUÇÃO } \\
1970-1975\end{array}$}} & \multirow{2}{*}{\multicolumn{2}{|c|}{$\begin{array}{c}\% \\
\text { VALOR } \\
1970-1975\end{array}$}} \\
\hline$D E$ & & A & & & & & & \\
\hline 5 & $\vdash$ & 10 & 2.6 & 3.6 & 0.2 & 0.4 & 0.2 & 0.4 \\
\hline 10 & $\vdash$ & 20 & 1.1 & 1.7 & 1.0 & 2.1 & 0.8 & 2.0 \\
\hline 20 & $\vdash$ & 50 & 4.7 & 8.6 & 4.6 & 9.4 & 4.4 & 8.9 \\
\hline 50 & $\vdash$ & 100 & 8.9 & 12.7 & 8.5 & 13.4 & 8.2 & 12.9 \\
\hline 100 & $\vdash$ & 200 & 16.5 & 18.2 & 15.9 & 18.5 & 15.1 & 18.3 \\
\hline 200 & $\vdash$ & 500 & 24.9 & 27.9 & 27.0 & 27.9 & 27.4 & 27.9 \\
\hline 500 & $\vdash$ & 1000 & 22.8 & 16.6 & 22.8 & 15.2 & 23.0 & 15.6 \\
\hline$-a m n$ & - & 2noo & 10.1 & 8.4 & 11.5 & 8.2 & 11.8 & 8.4 \\
\hline 2000 & $\vdash$ & 5000 & 6.8 & 3.1 & 6.4 & 2.6 & 6.0 & 2.7 \\
\hline 5000 & $\vdash$ & 10000 & $0 . ;$ & 1.3 & 0.4 & 1.4 & 0.2 & 1.5 \\
\hline 10000 & $\vdash$ & 100000 & 1.2 & 1.4 & 1.5 & 1.3 & 2.2 & 1.4 \\
\hline FONTE: & & 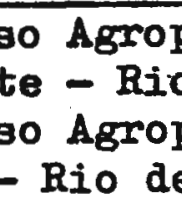 & & & & & & \\
\hline
\end{tabular}


TABELA A2. L PESSOAI OCUPADO: MULHERES NA MRH-ASSIS ENTRE 1970 e 1975

\begin{tabular}{|c|c|c|c|c|c|c|c|c|}
\hline \multirow[b]{2}{*}{ LOCAL } & \multirow{2}{*}{$\left|\begin{array}{l}A \\
N \\
b \\
s\end{array}\right|$} & \multicolumn{2}{|c|}{$\mathrm{T} 0 \mathrm{~T} A \mathrm{I} \mathrm{S}$} & \multicolumn{2}{|c|}{$\%$ TOTAL DE } & \multicolumn{3}{|c|}{ MULHERES } \\
\hline & & $\begin{array}{l}\text { PESSOAL } \\
\text { OCUPADO }\end{array}$ & $\begin{array}{l}\text { TOTAI } \\
\text { MULH. }\end{array}$ & $\begin{array}{l}\text { NAO } \\
\text { REMUN. }\end{array}$ & $\begin{array}{l}\text { EMPRR. } \\
\text { PERM. }\end{array}$ & $\begin{array}{l}\text { EMMP. } \\
\text { TEMP. }\end{array}$ & PARC & $\begin{array}{l}\text { OUT } \\
\text { COND }\end{array}$ \\
\hline ASSIS & $\begin{array}{l}70 \\
75 \\
\end{array}$ & $\begin{array}{l}4.502 \\
6.248 \\
\end{array}$ & $\begin{array}{r}730 \\
1.913 \\
\end{array}$ & $\begin{array}{l}92,8 \\
62,8 \\
\end{array}$ & $\begin{array}{r}3,42 \\
30,95 \\
\end{array}$ & $\begin{array}{r}2,8 \\
5,8 \\
\end{array}$ & $\begin{array}{l}0,14 \\
0,05\end{array}$ & 0.37 \\
\hline BORA & $\begin{array}{l}70 \\
75 \\
\end{array}$ & $\begin{array}{l}330 \\
639\end{array}$ & $\begin{array}{l}174 \\
218 \\
\end{array}$ & $\begin{array}{l}95,6 \\
37,6 \\
\end{array}$ & $\begin{array}{r}4,39 \\
53,21 \\
\end{array}$ & $\overline{0,46}$ & $8, \overline{26}$ & $\overline{0}, 46$ \\
\hline $\begin{array}{l}\text { CAMPOS } \\
\text { ROVOS }\end{array}$ & $\begin{array}{l}70 \\
75 \\
\end{array}$ & $\begin{array}{l}1.144 \\
1.261 \\
\end{array}$ & $\begin{array}{l}112 \\
124 \\
\end{array}$ & $\begin{array}{r}100,0 \\
83,87 \\
\end{array}$ & 17,29 & 4,03 & $0, \overline{81}$ & - \\
\hline $\begin{array}{l}\text { CÂNDIDO } \\
\text { MOTA }\end{array}$ & $\begin{array}{l}70 \\
75\end{array}$ & $\begin{array}{r}6.786 \\
3.842 \\
\end{array}$ & $\begin{array}{r}1.321 \\
625 \\
\end{array}$ & $\begin{array}{l}82,2 \\
88,5 \\
\end{array}$ & $\begin{array}{l}3,48 \\
7,52 \\
\end{array}$ & $\begin{array}{r}13,2 \\
3,84 \\
\end{array}$ & $\begin{array}{l}0,83 \\
C .16 \\
\end{array}$ & \\
\hline CRUZALIA & $\begin{array}{l}70 \\
75 \\
\end{array}$ & $\begin{array}{l}2.102 \\
1.353 \\
\end{array}$ & $\begin{array}{l}292 \\
124 \\
\end{array}$ & $\begin{array}{l}89,73 \\
85,48 \\
\end{array}$ & $\begin{array}{l}1,71 \\
1,61\end{array}$ & $\begin{array}{r}7,19 \\
12,0 n \\
\end{array}$ & $\begin{array}{c}1,37 \\
-\end{array}$ & - \\
\hline ECHAPORA & $\begin{array}{l}70 \\
75 \\
\end{array}$ & $\begin{array}{l}2.537 \\
2.777 \\
\end{array}$ & $\begin{array}{l}569 \\
55 ? \\
\end{array}$ & $\begin{array}{l}87,87 \\
44,93 \\
\end{array}$ & $\begin{array}{r}7.38 \\
33.51 \\
\end{array}$ & $\begin{array}{r}4,75 \\
18,84 \\
\end{array}$ & 1,09 & 1,63 \\
\hline FLOR INEA & $\begin{array}{l}70 \\
75 \\
\end{array}$ & $\begin{array}{l}1.503 \\
2.689 \\
\end{array}$ & $\begin{array}{l}435 \\
556 \\
\end{array}$ & $\begin{array}{l}95,86 \\
64,21 \\
\end{array}$ & $\begin{array}{l}2,07 \\
3,60 \\
\end{array}$ & $\begin{array}{r}2,76 \\
32,19 \\
\end{array}$ & - & 2,07 \\
\hline IBIRAREMA & $\begin{array}{l}70 \\
75 \\
\end{array}$ & $\begin{array}{r}1.599 \\
940 \\
\end{array}$ & $\begin{array}{l}509 \\
109 \\
\end{array}$ & $\begin{array}{l}99,21 \\
95,47\end{array}$ & $\begin{array}{l}0.79 \\
4.59 \\
\end{array}$ & - & $\overline{-}$ & \\
\hline IUTÉCIA & $\begin{array}{l}70 \\
75 \\
\end{array}$ & $\begin{array}{l}1.488 \\
1.682 \\
\end{array}$ & $\begin{array}{l}372 \\
420 \\
\end{array}$ & $\begin{array}{l}85,22 \\
48,57 \\
\end{array}$ & $\begin{array}{r}8,05 \\
12,62 \\
\end{array}$ & $\begin{array}{r}5,11 \\
38,33 \\
\end{array}$ & $\begin{array}{l}0,27 \\
0,48 \\
\end{array}$ & $1, \overline{34}$ \\
\hline MARACAI & $\begin{array}{l}70 \\
75\end{array}$ & $\begin{array}{l}2.327 \\
4.499 \\
\end{array}$ & $\begin{array}{r}343 \\
1.500 \\
\end{array}$ & $\begin{array}{l}97,08 \\
76,80 \\
\end{array}$ & $\begin{array}{r}2,92 \\
17,07 \\
\end{array}$ & 6,07 & $\overline{-}$ & $\overline{0,07}$ \\
\hline $\begin{array}{l}\text { OSCAR } \\
\text { BRESSANE }\end{array}$ & $\begin{array}{l}70 \\
75 \\
\end{array}$ & $\begin{array}{l}1.272 \\
1.572 \\
\end{array}$ & $\begin{array}{l}184 \\
460 \\
\end{array}$ & $\begin{array}{r}100,0 \\
92,61 \\
\end{array}$ & 4.57 & 2.17 & 0,65 & - \\
\hline PAIMITAL & $\begin{array}{l}70 \\
75\end{array}$ & $\begin{array}{l}4.677 \\
5.341 \\
\end{array}$ & $\begin{array}{l}726 \\
536 \\
\end{array}$ & $\begin{array}{l}94,9 \\
86,2\end{array}$ & $\begin{array}{l}4,27 \\
7,65\end{array}$ & 5,97 & $\begin{array}{l}0,55 \\
0,19\end{array}$ & $\begin{array}{c}0,28 \\
-\end{array}$ \\
\hline $\begin{array}{l}\text { PARAGUASSÚ } \\
\text { PAULISTA }\end{array}$ & $\begin{array}{l}70 \\
75 \\
\end{array}$ & $\begin{array}{l}3.807 \\
3.782 \\
\end{array}$ & $\begin{array}{l}894 \\
844 \\
\end{array}$ & $\begin{array}{l}81,8 \\
72,63\end{array}$ & $\begin{array}{l}14,54 \\
18,13 \\
\end{array}$ & $\begin{array}{l}3,02 \\
5,09\end{array}$ & $\begin{array}{l}0,22 \\
1,30 \\
\end{array}$ & $\begin{array}{l}0,34 \\
2,84 \\
\end{array}$ \\
\hline PIATINA & $\begin{array}{l}70 \\
75 \\
\end{array}$ & $\begin{array}{l}882 \\
693 \\
\end{array}$ & $\begin{array}{r}157 \\
59 \\
\end{array}$ & $\begin{array}{l}96,18 \\
91,53 \\
\end{array}$ & $\begin{array}{c}1,27 \\
-\end{array}$ & $\begin{array}{l}0,64 \\
8,47 \\
\end{array}$ & $\begin{array}{r}1,91 \\
- \\
\end{array}$ & - \\
\hline QUATA & $\begin{array}{l}70 \\
75 \\
\end{array}$ & $\begin{array}{l}2.286 \\
3.794\end{array}$ & $\begin{array}{l}476 \\
811\end{array}$ & $\begin{array}{l}96,83 \\
16,09\end{array}$ & $\begin{array}{r}2,96 \\
19,73 \\
\end{array}$ & $\begin{array}{r}0,21 \\
11,59 \\
\end{array}$ & $1, \overline{23}$ & $1, \overline{36}$ \\
\hline
\end{tabular}

FONTE: Censo Agropecuário de São Paulo, IBGE, 1970,1975. 
TABELA A3. PERCENTAGEM DE PARTICIPAÇÃO DAS MULHERES NOS GRUPOS DE PESSOAI OCUPADO NO MRH-AM 1970-1975

\begin{tabular}{|c|c|c|c|c|c|c|c|c|}
\hline \multirow[b]{2}{*}{ LOCAL } & \multirow{2}{*}{$\begin{array}{l}A \\
N \\
0 \\
S\end{array}$} & \multirow{2}{*}{$\begin{array}{l}\text { PESSOAL } \\
\text { OCUPADO }\end{array}$} & \multicolumn{6}{|c|}{$M$ U I H ER E S (8) } \\
\hline & & & $\begin{array}{c}\% \\
\text { TOTAL }\end{array}$ & $\begin{array}{l}\text { ERESP.t } \\
\$ \$\end{array}$ & $\begin{array}{l}\text { EMPP. } \\
\text { PERM. }\end{array}$ & $\begin{array}{l}\text { EMP. } \\
\text { TEMP. }\end{array}$ & PARC. & $\begin{array}{l}\text { OuTR } \\
\text { COND }\end{array}$ \\
\hline ASSIS & $\begin{array}{l}70 \\
75\end{array}$ & $\begin{array}{l}4.502 \\
6.248\end{array}$ & $\begin{array}{l}15.06 \\
30,6\end{array}$ & $\begin{array}{l}16,2 \\
19,2\end{array}$ & $\begin{array}{l}0,55 \\
9,47\end{array}$ & $\begin{array}{l}0,46 \\
1,77\end{array}$ & $\begin{array}{l}0,02 \\
0,01\end{array}$ & 0,17 \\
\hline BORA & $\begin{array}{l}70 \\
75\end{array}$ & $\begin{array}{l}330 \\
639\end{array}$ & $\begin{array}{l}34,5 \\
34,1\end{array}$ & $\begin{array}{l}33,0 \\
12,8\end{array}$ & $\begin{array}{c}1,51 \\
18,1\end{array}$ & $\overline{0,15}$ & 2,8 & 0,15 \\
\hline $\begin{array}{l}\text { CAMPOS } \\
\text { MOVOS } \\
\text { PAULISTA } \\
\end{array}$ & $\begin{array}{l}70 \\
75\end{array}$ & $\begin{array}{l}1.144 \\
1.261\end{array}$ & $\begin{array}{l}1,79 \\
9,83\end{array}$ & $\overline{8}, 24$ & $\overline{1,11}$ & 0,39 & 0,08 & - \\
\hline $\begin{array}{l}\text { CANDIDO } \\
\text { MOTA }\end{array}$ & $\begin{array}{l}70 \\
75\end{array}$ & $\begin{array}{l}6.186 \\
3.842\end{array}$ & $\begin{array}{l}21,35 \\
16,26\end{array}$ & $\begin{array}{l}17,5 \\
14,4\end{array}$ & $\begin{array}{l}0,74 \\
1,21\end{array}$ & $\begin{array}{l}2,78 \\
0,62\end{array}$ & $\begin{array}{l}0,18 \\
0,02\end{array}$ & - \\
\hline CRUZAIIA & $\begin{array}{l}70 \\
75\end{array}$ & $\begin{array}{l}2.102 \\
1.353\end{array}$ & $\begin{array}{r}13,89 \\
9,16\end{array}$ & $\begin{array}{r}12,46 \\
7,83\end{array}$ & $\begin{array}{l}0,24 \\
0,14\end{array}$ & $\begin{array}{l}1,0 \\
7,18\end{array}$ & 0,13 & - \\
\hline ECHAPOR & $\begin{array}{l}70 \\
75\end{array}$ & $\begin{array}{l}2.537 \\
2.777\end{array}$ & $\begin{array}{l}22,42 \\
24,24\end{array}$ & $\begin{array}{l}20,8 \\
10,9\end{array}$ & $\begin{array}{l}1,65 \\
8,12\end{array}$ & $\begin{array}{l}1,06 \\
4,56\end{array}$ & $\overline{0,26}$ & 0,39 \\
\hline FLORINEA & $\begin{array}{l}70 \\
75\end{array}$ & $\begin{array}{l}1.503 \\
2.689\end{array}$ & $\begin{array}{l}2.8,9 \\
20,6\end{array}$ & $\begin{array}{r}27,7 \\
9,5\end{array}$ & $\begin{array}{l}0,59 \\
0,74\end{array}$ & $\begin{array}{l}0,79 \\
6,66\end{array}$ & - & - \\
\hline IBIRAREMA & $\begin{array}{l}70 \\
75\end{array}$ & $\begin{array}{r}1.599 \\
940\end{array}$ & $\begin{array}{l}31,8 \\
11,6\end{array}$ & $\begin{array}{l}31,5 \\
11,0\end{array}$ & $\begin{array}{l}0,25 \\
0,53\end{array}$ & - & - & - \\
\hline IUTECIA & $\begin{array}{l}70 \\
75\end{array}$ & $\begin{array}{l}1.488 \\
1.682\end{array}$ & $\begin{array}{l}25,0 \\
24,9\end{array}$ & $\begin{array}{l}21,3 \\
12,3\end{array}$ & $\begin{array}{l}2,01 \\
3,15\end{array}$ & $\begin{array}{l}1,27 \\
9,57\end{array}$ & $\begin{array}{l}0,06 \\
0,12\end{array}$ & - \\
\hline MARACAf & $\begin{array}{l}70 \\
75\end{array}$ & $\begin{array}{l}2.327 \\
4.499\end{array}$ & $\begin{array}{l}14,7 \\
33,3\end{array}$ & $\begin{array}{l}14,3 \\
25,6\end{array}$ & $\begin{array}{l}0,43 \\
5,7\end{array}$ & 2,02 & - & 0,02 \\
\hline $\begin{array}{l}\text { OSCAR } \\
\text { BRESSANE }\end{array}$ & $\begin{array}{l}70 \\
75\end{array}$ & $\begin{array}{l}1.272 \\
1.572\end{array}$ & $\begin{array}{l}14,8 \\
29,3\end{array}$ & $\begin{array}{l}14,8 \\
27,1\end{array}$ & 1,34 & 0,64 & 0,19 & - \\
\hline PALMITAL & $\begin{array}{l}70 \\
75\end{array}$ & $\begin{array}{l}4.677 \\
5.341\end{array}$ & $\begin{array}{l}15,5 \\
10,0\end{array}$ & $\begin{array}{r}14,7 \\
8,65\end{array}$ & $\begin{array}{l}0,666 \\
0,77\end{array}$ & $\overline{0,60}$ & $\begin{array}{l}0,08 \\
0,02\end{array}$ & - \\
\hline $\begin{array}{r}\text { PARAGUA ÇU } \\
\text { PAUIISTA }\end{array}$ & $\begin{array}{l}70 \\
75\end{array}$ & $\begin{array}{l}3.807 \\
3.782\end{array}$ & $\begin{array}{l}23,4 \\
22,3\end{array}$ & $\begin{array}{l}19,2 \\
16,21\end{array}$ & $\begin{array}{l}3,41 \\
4,05\end{array}$ & $\begin{array}{l}0,71 \\
1,14\end{array}$ & $\begin{array}{l}0,05 \\
0,30\end{array}$ & 0,63 \\
\hline PLATINA & $\begin{array}{l}70 \\
75\end{array}$ & $\begin{array}{l}882 \\
693\end{array}$ & $\begin{array}{r}17,8 \\
8,5\end{array}$ & $\begin{array}{r}17,7 \\
7,7\end{array}$ & $\begin{array}{c}0,22 \\
-\end{array}$ & $\begin{array}{l}0,11 \\
0,72\end{array}$ & 0,34 & - \\
\hline QUATA & $\begin{array}{l}70 \\
75\end{array}$ & $\begin{array}{l}2.286 \\
3.794\end{array}$ & $\begin{array}{l}20,7 \\
21,3\end{array}$ & $\begin{array}{l}20,0 \\
14,1\end{array}$ & $\begin{array}{l}0,61 \\
2,48\end{array}$ & $\begin{array}{l}0,04 \\
0,26\end{array}$ & 0,29 & - \\
\hline
\end{tabular}

FONTE: calculado do Censo Agropecuário do Estado de São Paulo IBGE, 1970 e 1975. 
TABEIA A4. PESSOAL OCUPADO - MENORES DE 14 ANOSMRH-ASSIS - 1970/75

\begin{tabular}{|c|c|c|c|c|c|c|c|c|}
\hline \multirow[b]{2}{*}{ IOCAL } & \multirow{2}{*}{$\left|\begin{array}{l}A \\
\mathbb{N} \\
0 \\
\mathbf{S}\end{array}\right|$} & \multirow{2}{*}{$\begin{array}{c}\text { PESSOAT } \\
\text { OCUPADO } \\
\text { TOTAT }\end{array}$} & \multirow{2}{*}{$\begin{array}{l}\text { MERTORES : } \\
\text { TOT. P/ } \\
\text { MUNICIP. }\end{array}$} & \multicolumn{5}{|c|}{ PORCENIAGEM } \\
\hline & & & & $\begin{array}{l}\text { NÃO } \\
\text { RENUN }\end{array}$ & $\begin{array}{l}\text { EMPP. } \\
\text { PERM. }\end{array}$ & FMP. & PARC。 & OUT. \\
\hline ASSIS & $\begin{array}{l}70 \\
75\end{array}$ & $\begin{array}{l}4.502 \\
6.248\end{array}$ & $\begin{array}{r}352 \\
1.547\end{array}$ & $\begin{array}{l}92,6 \\
51,9\end{array}$ & $\begin{array}{r}7,4 \\
46,6\end{array}$ & 1,10 & - & - \\
\hline BORA & $\begin{array}{r}70 \\
75\end{array}$ & $\begin{array}{l}330 \\
639\end{array}$ & $\begin{array}{r}30 \\
225\end{array}$ & $\begin{array}{r}100,0 \\
31,1\end{array}$ & 60,4 & $\overline{0,9}$ & $\overline{8,0}$ & - \\
\hline $\begin{array}{l}\text { CAMPOS } \\
\text { NOVOS }\end{array}$ & $\begin{array}{r}70 \\
75 \\
\end{array}$ & $\begin{array}{l}1.114 \\
1.261\end{array}$ & $\begin{array}{r}85 \\
113 \\
\end{array}$ & $\begin{array}{l}96,5 \\
92,0 \\
\end{array}$ & $\begin{array}{l}1,2 \\
7,9 \\
\end{array}$ & - & $\begin{array}{c}2,3 \\
- \\
\end{array}$ & $=$ \\
\hline $\begin{array}{l}\text { CANTIIDO } \\
\text { MOTA }\end{array}$ & $\begin{array}{l}70 \\
75 \\
\end{array}$ & $\begin{array}{l}6.186 \\
3.842 \\
\end{array}$ & $\begin{array}{l}708 \\
343 \\
\end{array}$ & $\begin{array}{l}95,1 \\
83,6 \\
\end{array}$ & $\begin{array}{r}3,5 \\
14,3 \\
\end{array}$ & 2,04 & $\begin{array}{l}1, C \\
- \\
\end{array}$ & $\begin{array}{r}0,4 \\
- \\
\end{array}$ \\
\hline CRUZAIIA & $\begin{array}{l}70 \\
25\end{array}$ & $\begin{array}{l}2.102 \\
1.353 \\
\end{array}$ & $\begin{array}{r}113 \\
54 \\
\end{array}$ & $\begin{array}{r}92,9 \\
100,0 \\
\end{array}$ & $\begin{array}{c}3,5 \\
- \\
\end{array}$ & - & $\begin{array}{c}0,9 \\
- \\
\end{array}$ & - \\
\hline SCHAPORA & $\begin{array}{l}7.0 \\
7.5 \\
\end{array}$ & $\begin{array}{l}2.537 \\
2.277 \\
\end{array}$ & $\begin{array}{l}304 \\
343 \\
\end{array}$ & $\begin{array}{l}85,9 \\
40,5 \\
\end{array}$ & $\begin{array}{l}13,8 \\
36,1 \\
\end{array}$ & $\begin{array}{l}0,3 \\
5,8 \\
\end{array}$ & 0,3 & - \\
\hline FLOR INEA & $\begin{array}{l}70 \\
75\end{array}$ & $\begin{array}{l}1.503 \\
2.689\end{array}$ & $\begin{array}{l}321 \\
333 \\
\end{array}$ & $\begin{array}{l}95,0 \\
91,3 \\
\end{array}$ & $\begin{array}{l}4,4 \\
2,1 \\
\end{array}$ & $\begin{array}{l}2,2 \\
6,6 \\
\end{array}$ & - & $\begin{array}{c}0,6 \\
- \\
\end{array}$ \\
\hline IBIRAREMA & $\begin{array}{l}70 \\
75 \\
\end{array}$ & $\begin{array}{r}1.599 \\
940 \\
\end{array}$ & $\begin{array}{r}185 \\
37 \\
\end{array}$ & $\begin{array}{r}99,5 \\
100,0 \\
\end{array}$ & $\begin{array}{r}0,5 \\
- \\
\end{array}$ & - & - & - \\
\hline LUTECIA & $\begin{array}{l}70 \\
75 \\
\end{array}$ & $\begin{array}{l}1.488 \\
1.682 \\
\end{array}$ & $\begin{array}{l}191 \\
176 \\
\end{array}$ & $\begin{array}{l}85,3 \\
73,8 \\
\end{array}$ & \begin{tabular}{|l|}
14,7 \\
23,3 \\
\end{tabular} & 2,84 & $\overline{-}$ & $\overline{-}$ \\
\hline MaRACAI & $\begin{array}{l}7.9 \\
75\end{array}$ & $\begin{array}{r}2.327 \\
4.449 \\
\end{array}$ & $\begin{array}{r}127 \\
1.104 \\
\end{array}$ & $\begin{array}{l}99,2 \\
72,7 \\
\end{array}$ & $\begin{array}{r}0,8 \\
23,3 \\
\end{array}$ & 3,98 & - & - \\
\hline $\begin{array}{l}\text { OSCAR } \\
\text { BRESSANE } \\
\end{array}$ & $\begin{array}{l}70 \\
75 \\
\end{array}$ & $\begin{array}{l}1.272 \\
1.572 \\
\end{array}$ & $\begin{array}{r}0 \\
280 \\
\end{array}$ & 93,5 & 5,0 & - & $\overline{1,42}$ & - \\
\hline PAIMITAI & \begin{tabular}{|}
70 \\
75 \\
\end{tabular} & $\begin{array}{l}4.677 \\
5.341 \\
\end{array}$ & $\begin{array}{l}297 \\
150 \\
\end{array}$ & $\begin{array}{l}93.9 \\
93.3 \\
\end{array}$ & $\begin{array}{l}4,0 \\
5,3 \\
\end{array}$ & - & $\begin{array}{l}1,7 \\
1,33 \\
\end{array}$ & 0,3 \\
\hline $\begin{array}{l}\text { PARAGUACUU } \\
\text { SÚ PAUL. }\end{array}$ & $\begin{array}{l}760 \\
75 \\
\end{array}$ & $\begin{array}{l}3.807 \\
3.782 \\
\end{array}$ & $\begin{array}{l}669 \\
645 \\
\end{array}$ & $\begin{array}{l}77,7 \\
75,8 \\
\end{array}$ & $\begin{array}{r}20,0 \\
19,8 \\
\end{array}$ & $\begin{array}{l}2,1 \\
0,15 \\
\end{array}$ & $\begin{array}{l}0,1 \\
1,24 \\
\end{array}$ & \\
\hline PLAT INA & $\begin{array}{l}70 \\
7.5 \\
\end{array}$ & $\begin{array}{l}882 \\
693 \\
\end{array}$ & $\begin{array}{l}50 \\
23 \\
\end{array}$ & $\begin{array}{r}96,0 \\
100,0 \\
\end{array}$ & - & - & $\begin{array}{r}4,0 \\
- \\
\end{array}$ & - \\
\hline QUATA & $\begin{array}{l}70 \\
75\end{array}$ & $\begin{array}{l}2.286 \\
3.794 \\
\end{array}$ & $\begin{array}{l}255 \\
342 \\
\end{array}$ & $\begin{array}{l}98,8 \\
64,6 \\
\end{array}$ & $\begin{array}{r}1,2 \\
29,5 \\
\end{array}$ & $\overline{3,21}$ & 0,87 & - \\
\hline
\end{tabular}

FONTE: Censo Agropecuário de São Paulo - IBGE 1970

Censo Agropecuário de São Paulo - IBGE 1975 
TABELA A5. PERCENTAGEM DE PARTICIPAÇÃO DOS MENORES DE 14 ANOS NOS GRUPOS DE PESSOAL OCUPADO NA MRH-ASSIS - 1970-1975

\begin{tabular}{|c|c|c|c|c|c|c|c|c|}
\hline \multirow{2}{*}{$\begin{array}{l}\text { MRH } \\
\text { ASSIS }\end{array}$} & \multirow[b]{2}{*}{${ }^{A}{ }_{O_{S}}$} & \multirow{2}{*}{$\begin{array}{l}\text { TOTAT } \\
\text { PESSOAT } \\
\text { OCUPADO }\end{array}$} & $\% \quad \mathrm{DE}$ & \multicolumn{2}{|c|}{ MENORES } & E I4 & ANOS & $:-$ \\
\hline & & & $\begin{array}{c}\% \mathrm{~s} / \\
\text { TOTAI }\end{array}$ & $\begin{array}{l}\text { RESP. } \\
\text { N REM. }\end{array}$ & $\begin{array}{l}\text { ERMPR。 } \\
\text { PERM. }\end{array}$ & $\begin{array}{l}\text { EMPRP. } \\
\text { TEMP. }\end{array}$ & PARC. & $\begin{array}{l}\text { outras } \\
\text { cond. }\end{array}$ \\
\hline ASSIS & $\begin{array}{l}70 \\
75 \\
\end{array}$ & $\begin{array}{l}4.502 \\
6.248 \\
\end{array}$ & $\begin{array}{r}7,82 \\
24,76 \\
\end{array}$ & $\begin{array}{r}7,24 \\
12,85 \\
\end{array}$ & 11,53 & $\overline{0}, 27$ & - & \\
\hline BORA & $\begin{array}{l}70 \\
75 \\
\end{array}$ & $\begin{array}{r}330 \\
1.261 \\
\end{array}$ & $\begin{array}{l}9,1 \\
8,96 \\
\end{array}$ & $\begin{array}{l}9,1 \\
8,24\end{array}$ & 0,71 & - & - & - \\
\hline $\begin{array}{l}\text { CAMPOS } \\
\text { NOVOS }\end{array}$ & $\begin{array}{l}70 \\
75 \\
\end{array}$ & $\begin{array}{l}1.114 \\
1.261 \\
\end{array}$ & $\begin{array}{l}7,43 \\
8,96 \\
\end{array}$ & $\begin{array}{l}7,17 \\
8,24 \\
\end{array}$ & $\begin{array}{l}0,09 \\
0,71 \\
\end{array}$ & - & 0,17 & $=$ \\
\hline $\begin{array}{l}\text { CANDIDO } \\
\text { MOTA }\end{array}$ & $\begin{array}{l}70 \\
75 \\
\end{array}$ & $\begin{array}{l}6.186 \\
3.842 \\
\end{array}$ & $\begin{array}{r}17,45 \\
8,92 \\
\end{array}$ & $\begin{array}{r}10.88 \\
7,47 \\
\end{array}$ & $\begin{array}{l}0,40 \\
1,27 \\
\end{array}$ & $\overline{0}, 18$ & $\begin{array}{l}0,11 \\
-\end{array}$ & $\begin{array}{l}0,05 \\
- \\
\end{array}$ \\
\hline CRUZÁLIA & $\begin{array}{l}70 \\
75 \\
\end{array}$ & $\begin{array}{r}2.702 \\
? .353 \\
\end{array}$ & $\begin{array}{l}5,38 \\
3,99\end{array}$ & $\begin{array}{l}5,00 \\
3,99 \\
\end{array}$ & $\begin{array}{c}0.19 \\
- \\
\end{array}$ & $\overline{-}$ & $\begin{array}{l}0,05 \\
- \\
\end{array}$ & - \\
\hline ECHAPORA & $\begin{array}{l}70 \\
75 \\
\end{array}$ & $\begin{array}{l}2.537 \\
2.277 \\
\end{array}$ & $\begin{array}{l}11,58 \\
15,09\end{array}$ & $\begin{array}{r}10,28 \\
6,11 \\
\end{array}$ & $\begin{array}{l}1,65 \\
5,45 \\
\end{array}$ & $\begin{array}{l}0,04 \\
0,87 \\
\end{array}$ & 0,04 & - \\
\hline FLORINEA & $\begin{array}{l}70 \\
75 \\
\end{array}$ & $\begin{array}{l}1.503 \\
2.689 \\
\end{array}$ & $\begin{array}{l}21,35 \\
12,38\end{array}$ & $\begin{array}{l}20,29 \\
11,30 \\
\end{array}$ & $\begin{array}{l}0,93 \\
0,26 \\
\end{array}$ & $\begin{array}{l}0,46 \\
0,81 \\
\end{array}$ & - & $\begin{array}{c}0,13 \\
- \\
\end{array}$ \\
\hline IBIRAREMA & $\begin{array}{l}70 \\
75 \\
\end{array}$ & $\begin{array}{r}1.599 \\
940 \\
\end{array}$ & $\begin{array}{l}11,86 \\
39,36 \\
\end{array}$ & $\begin{array}{l}11,80 \\
24,14 \\
\end{array}$ & 0,06 & - & - & - \\
\hline LUTÉCIA & $\begin{array}{l}70 \\
75 \\
\end{array}$ & $\begin{array}{l}1.488 \\
1.682 \\
\end{array}$ & $\begin{array}{l}12,83 \\
10,46 \\
\end{array}$ & $\begin{array}{r}10,95 \\
7,72 \\
\end{array}$ & $\begin{array}{l}1,88 \\
2,43 \\
\end{array}$ & 0,29 & $\overline{-}$ & - \\
\hline MARACAI & $\begin{array}{l}70 \\
75 \\
\end{array}$ & $\begin{array}{l}2.327 \\
4.449 \\
\end{array}$ & $\begin{array}{r}5,45 \\
24,53 \\
\end{array}$ & $\begin{array}{r}5,41 \\
17,84 \\
\end{array}$ & $\begin{array}{l}0,04 \\
5,71 \\
\end{array}$ & $\overline{0.97}$ & - & - \\
\hline $\begin{array}{l}\text { OSCAR } \\
\text { BRESSANE }\end{array}$ & $\begin{array}{l}70 \\
75 \\
\end{array}$ & $\begin{array}{l}1.272 \\
1.572 \\
\end{array}$ & 17.81 & 16,66 & $0, \overline{89}$ & - & $\overline{0}, 25$ & $=$ \\
\hline PAIMITAI & $\begin{array}{l}70 \\
75 \\
\end{array}$ & $\begin{array}{l}4.677 \\
5.341 \\
\end{array}$ & $\begin{array}{r}6,35 \\
3,31 \\
\end{array}$ & $\begin{array}{l}5,96 \\
3,31 \\
\end{array}$ & $\begin{array}{c}0,25 \\
-\end{array}$ & $\begin{array}{l}- \\
- \\
\end{array}$ & $\begin{array}{r}0,10 \\
- \\
\end{array}$ & $\begin{array}{c}0,02 \\
- \\
\end{array}$ \\
\hline $\begin{array}{l}\text { PARAGUASSU } \\
\text { PAULISTA }\end{array}$ & $\begin{array}{l}70 \\
75 \\
\end{array}$ & $\begin{array}{l}3.807 \\
3.782 \\
\end{array}$ & $\begin{array}{r}17,57 \\
2,80 \\
\end{array}$ & $\begin{array}{r}13,66 \\
2,62 \\
\end{array}$ & $\begin{array}{l}3,51 \\
0,15\end{array}$ & $\begin{array}{r}0,36 \\
- \\
\end{array}$ & $\begin{array}{l}0,02 \\
0,04 \\
\end{array}$ & - \\
\hline PLATINA & $\begin{array}{l}70 \\
75 \\
\end{array}$ & $\begin{array}{l}882 \\
693 \\
\end{array}$ & $\begin{array}{r}5,67 \\
17,05 \\
\end{array}$ & $\begin{array}{r}5,44 \\
12,92 \\
\end{array}$ & $3, \overline{38}$ & 0,02 & $\begin{array}{l}0,23 \\
0,21 \\
\end{array}$ & - \\
\hline QUATA & $\begin{array}{l}70 \\
75 \\
\end{array}$ & $\begin{array}{l}2.286 \\
3.794 \\
\end{array}$ & $\begin{array}{r}11,15 \\
2,01 \\
\end{array}$ & $\begin{array}{r}11,02 \\
5,82 \\
\end{array}$ & $\begin{array}{l}0,13 \\
2,66 \\
\end{array}$ & 0,28 & 0,08 & - \\
\hline
\end{tabular}

FONTE: Calculado do Censo Agropecuario de São Paulo, IBGE, 1970 e 1975. 


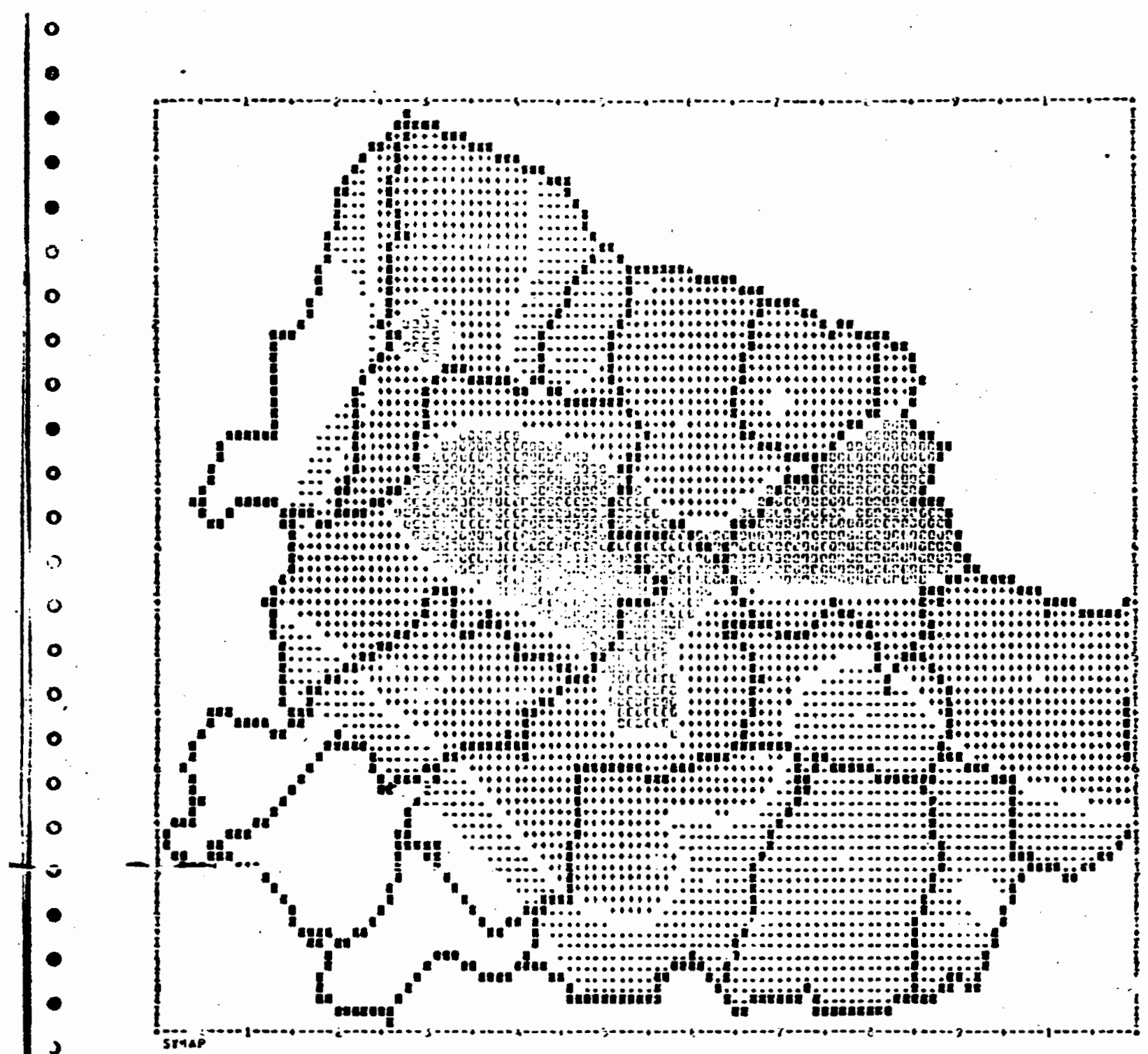

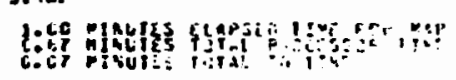

IIRE of [A\} = [3/3]

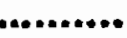

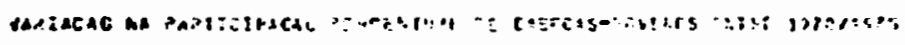

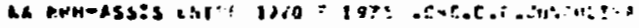

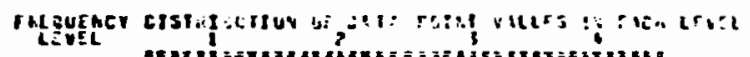

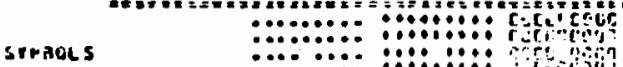

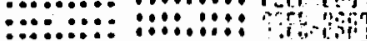

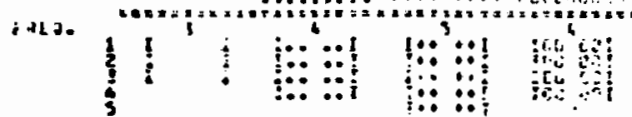

aty

Itre of gay + 20 ! 
A digitalização deste documento foi possível graças ao investimento do Programa de Pós-graduação em Geografia Humana (PPGH-FFLCH-USP) e realizada com recursos da Coordenação de Aperfeiçoamento de Pessoal de Nível Superior - Brasil (CAPES) - Código de Financiamento 001. Essa ação integra as atividades de comemoração dos 50 anos do PPGH no ano de 2021. Para mais informações sobre o PPGH e sua história, visite a página do programa: http://ppgh.fflch.usp.br/.

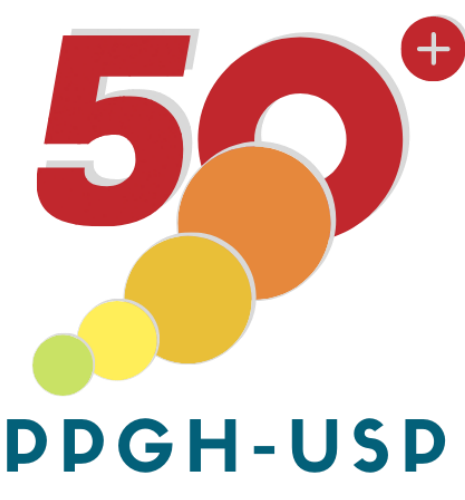

$1971-2021$ 